Fall 1952

\title{
1952 Cedrus Yearbook
}

\section{Cedarville College}

Follow this and additional works at: https://digitalcommons.cedarville.edu/yearbooks

Part of the Higher Education Commons, Organizational Communication Commons, and the Public Relations and Advertising Commons

\section{Recommended Citation}

Cedarville College, "1952 Cedrus Yearbook" (1952). Yearbooks. 62.

https://digitalcommons.cedarville.edu/yearbooks/62

This Book is brought to you for free and open access by DigitalCommons@Cedarville, a service of the Centennial Library. It has been accepted for inclusion in Yearbooks by an authorized administrator of DigitalCommons@Cedarville. For more information, please contact digitalcommons@cedarville.edu. 


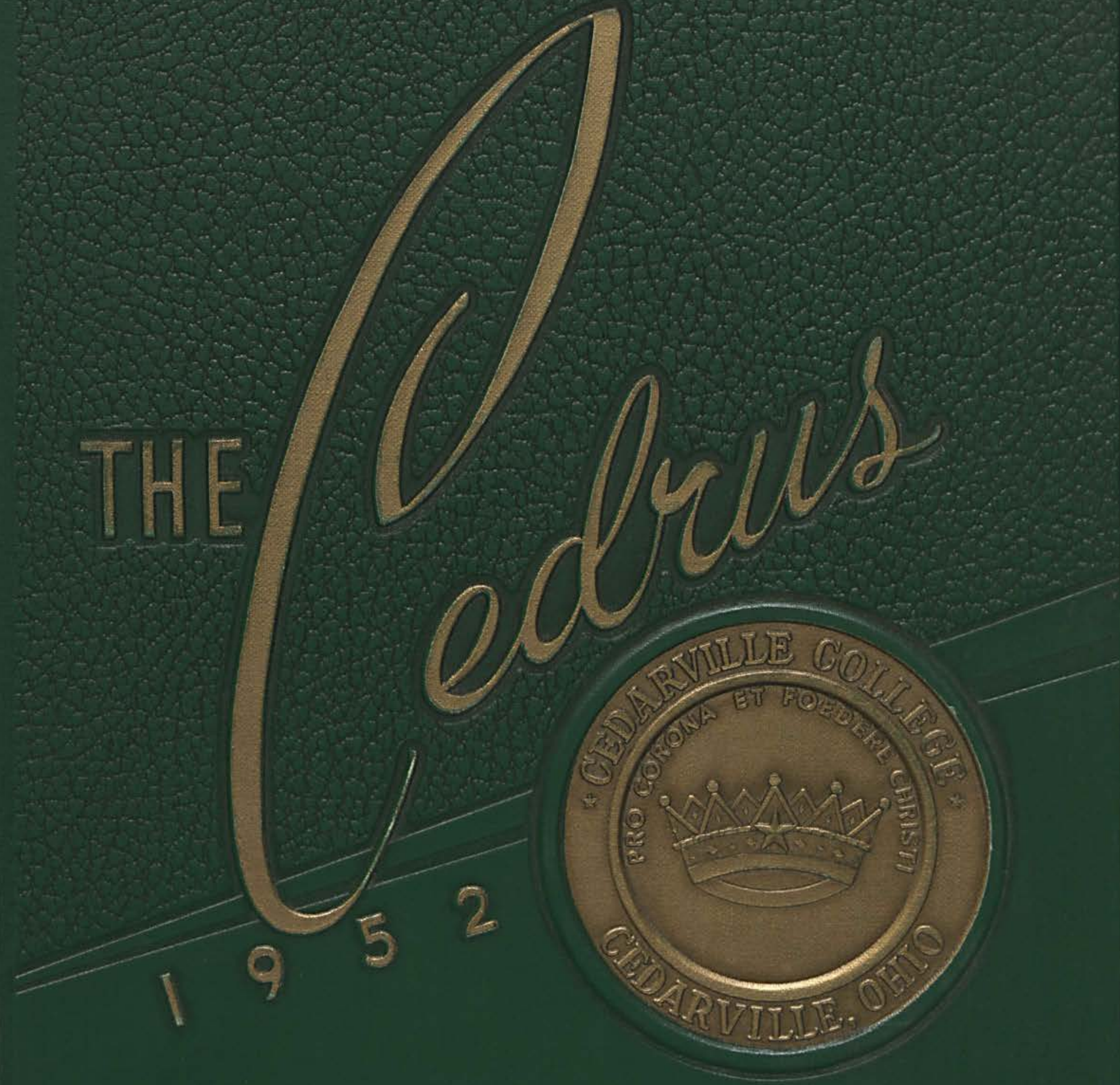


G.

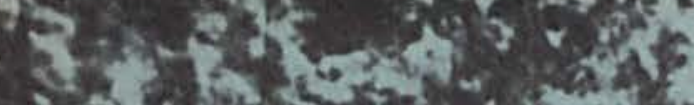

Not

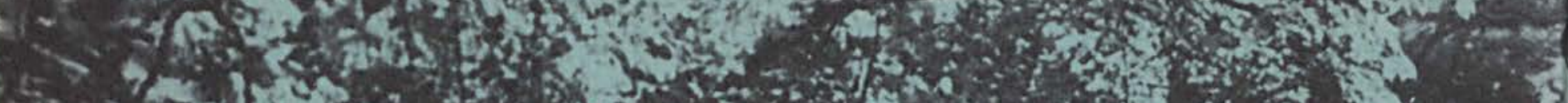

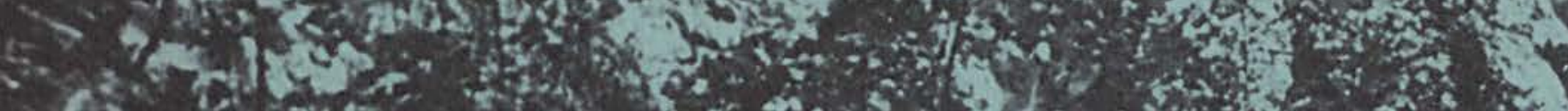

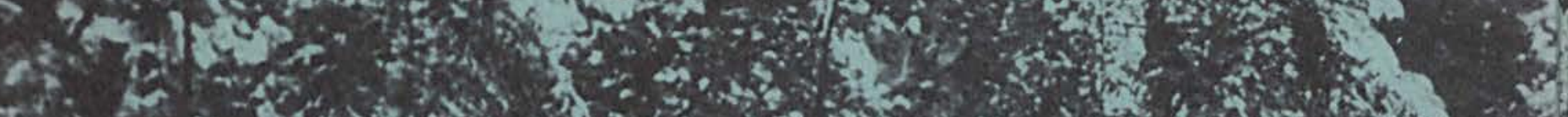

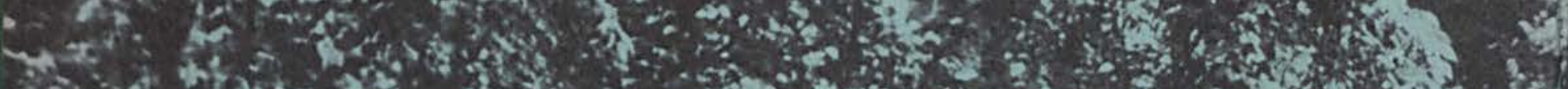
F-

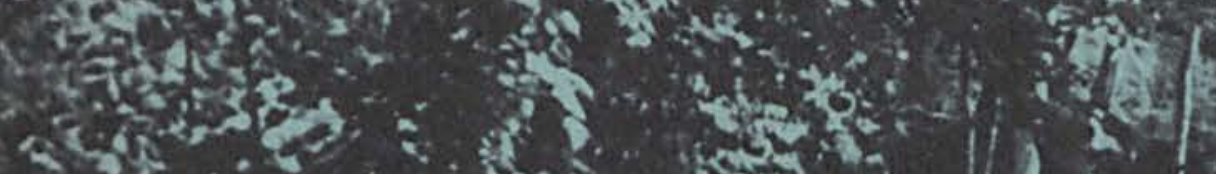

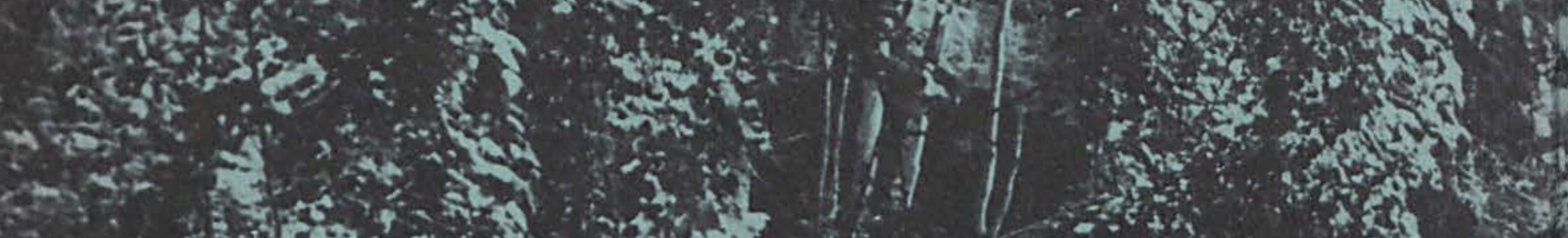

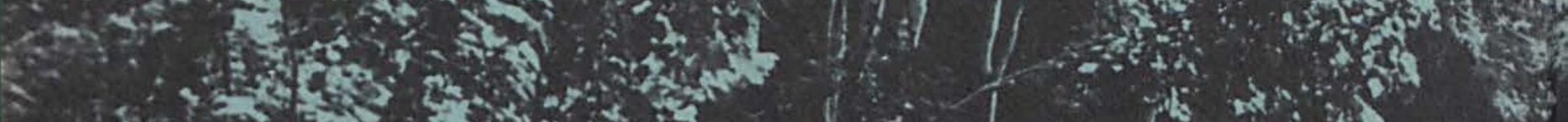

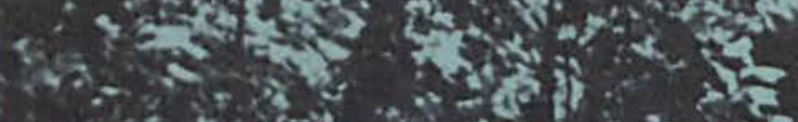

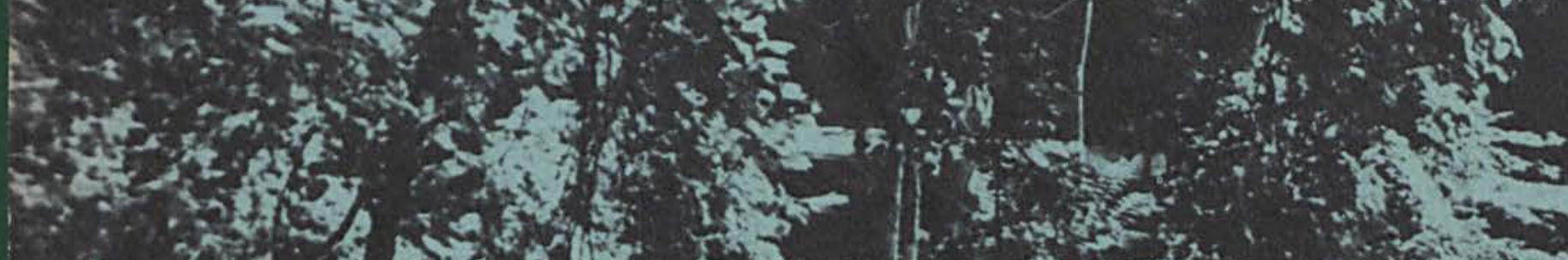

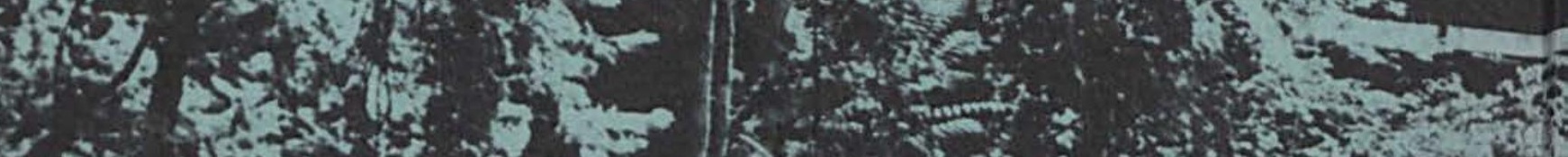

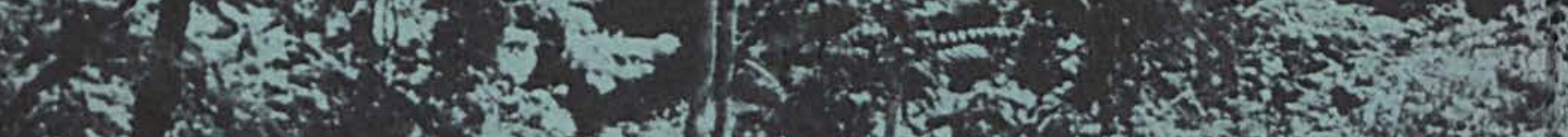

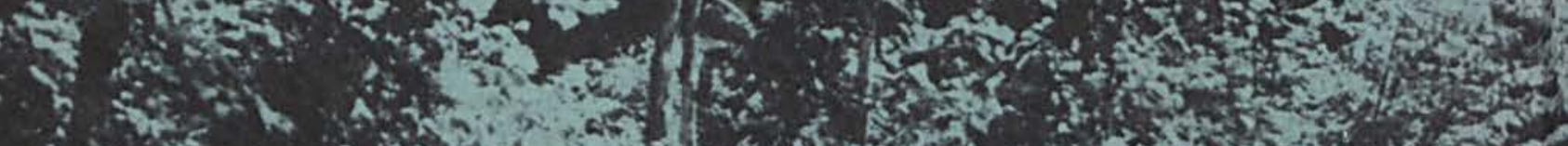

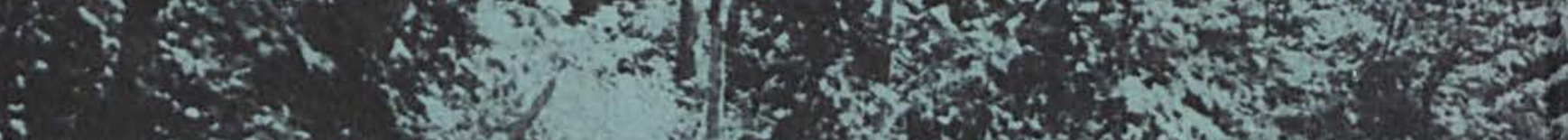

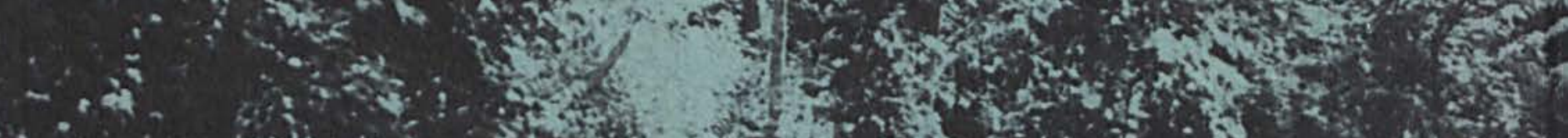

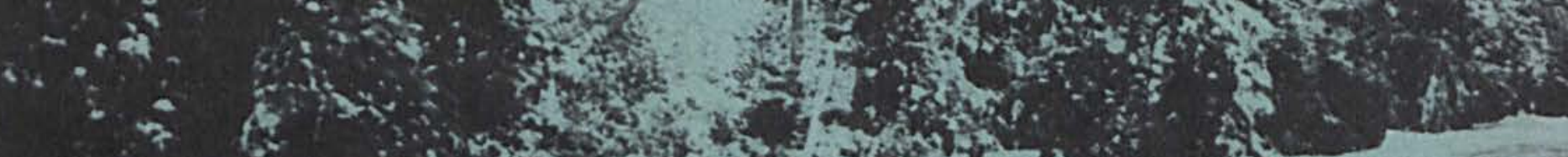

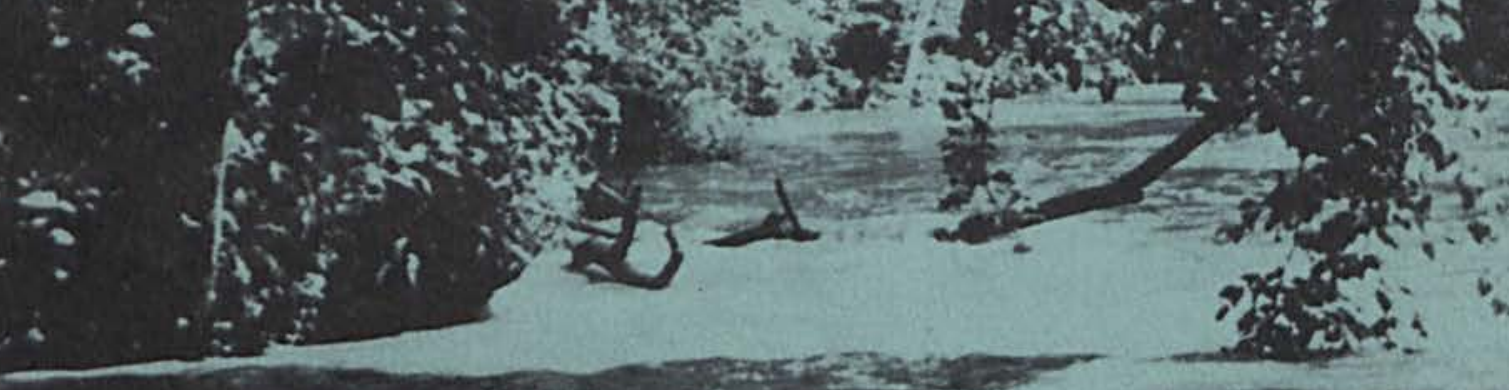
-

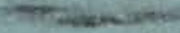

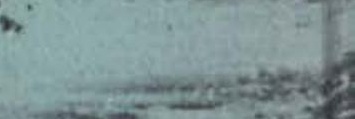




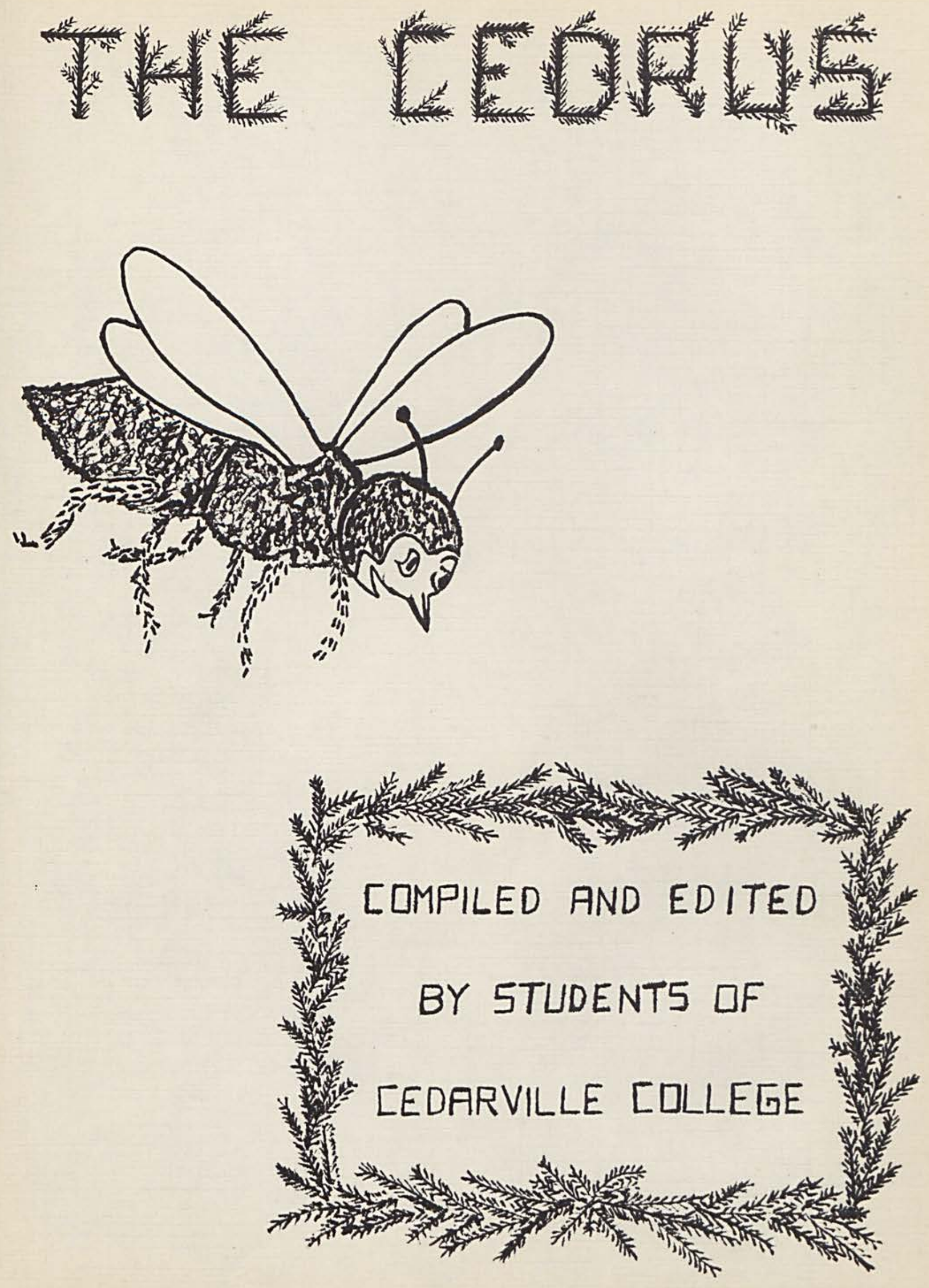

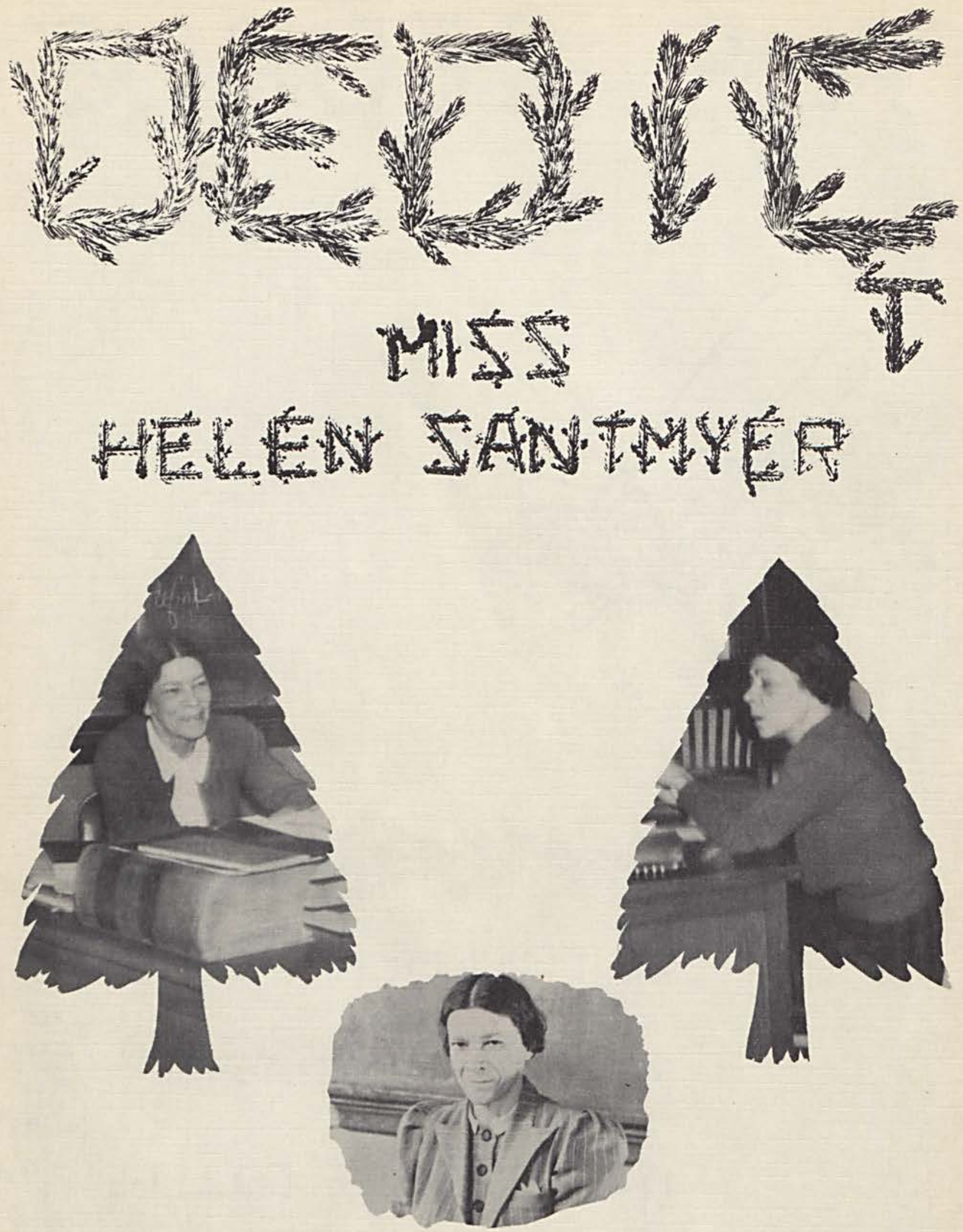

Who for sixteen years has had charge of the English Department, adding constantly to the prestige of Cedarville College, and equipping her students with a respectable knowledge of the vernacular. She came to us with an established reputation as a novelist. Her writings show a polish in content that gives them a permanent value that is refreshing in this day of trashy writing and would-be accomplishment.

Her class-room work has been masterly and thorough. The living products of her efforts testify to the thoroughness with which she has labored, and to her success in putting things across. English is English y'know. But to perfecther knowledge of English she has added Latin, Greek, French, and German, which have given her a mental balance rarely to be found anywhere. Long may she wave. 

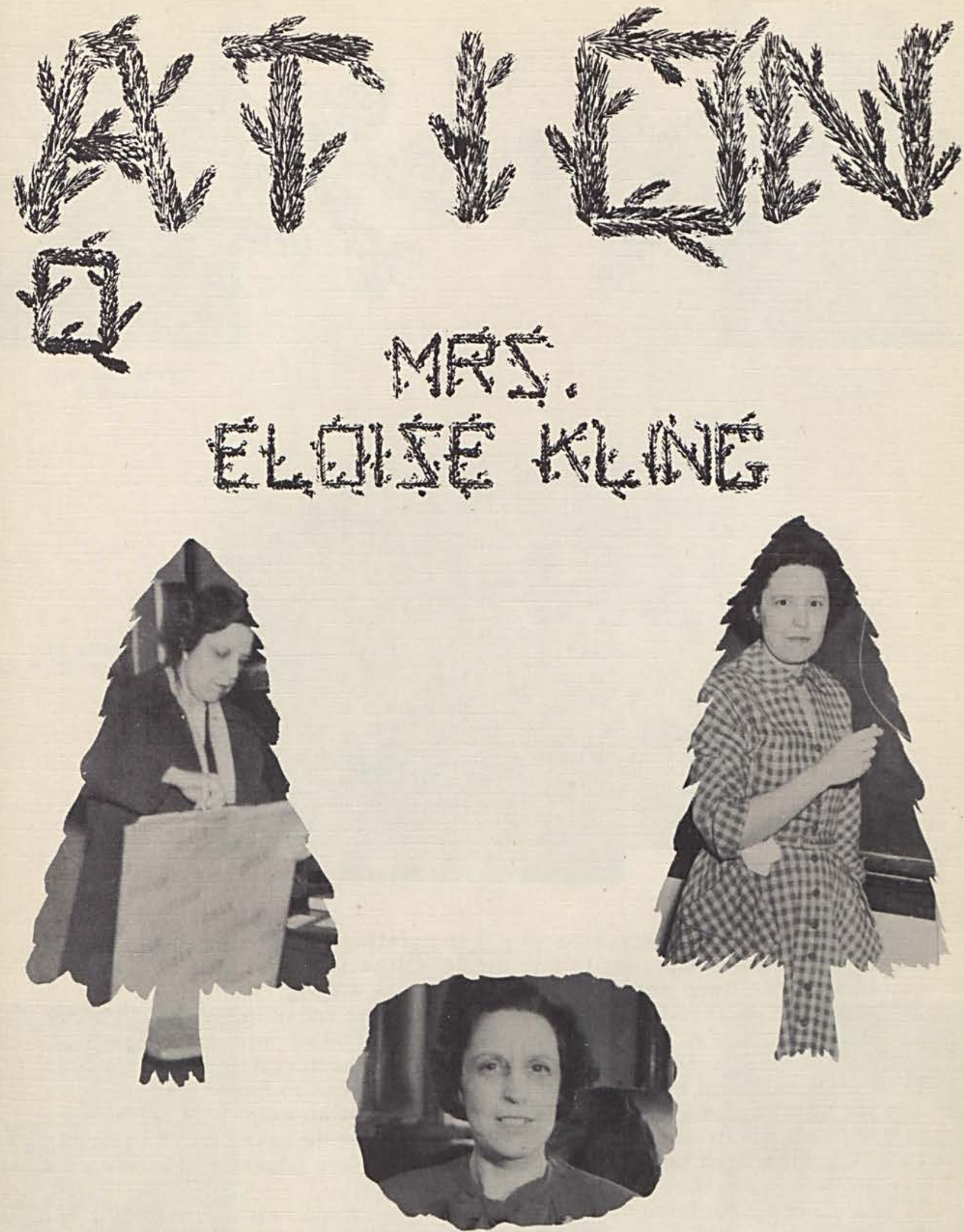

Because she has given years of her life to the cause of education, to her students in the Department of Elementary Education, to the college, whose reputation as a teachers training institution has grown through her service, and to the state, so many of whose teachers are the product of her class room.

Because she has taught not only untiringly but happily, with a never-failing sense of humor, with cheerfulness and a vigorous optimism, that has carried her students through their courses to the achievements aimed at.

Because she has undertaken, with every appearance of enjoyment, to answer all the calls, social and extracurricular, on her time and strength.

And because she's an awfully nice persor to have around, never out of humor, never cast down, a favorite figure on the campus, lugging the big brief case that is her trade mark. May Cedarville College long be blessed with her presence on its faculty. 

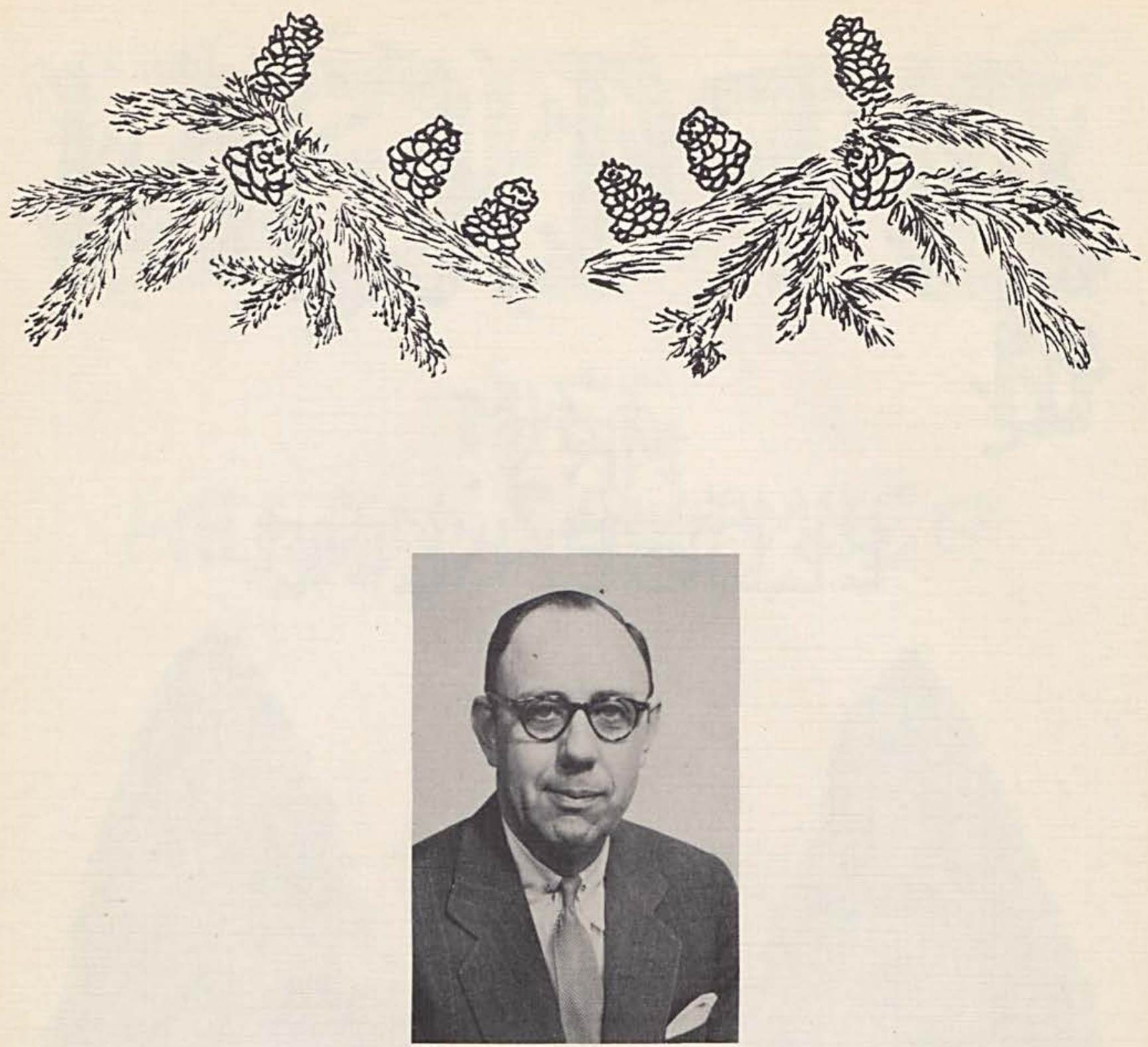

The challenge that the free world is meeting today from communism must produce a response, in our own civilization and culture, that will emphasize the deep sources of our spiritual strength.

Here at Cedarville College we believe that freedom is one of these sources. We believe that freedom of education and of enterprise are necessary if man's spirit is to be free, and that one function of the College is to safeguard and strengthen these freedoms, and to hand them down as a legacy for future generations. Where so great an emphasis on statism is prevalent in our country today, we must strive as never before to protect and strengthen the American system of private education of which we are an integral part.

As you go forth from this campus to new duties and new responsibilities, we can only hope that you will carry with you the banner of freedom, and that you will serve well your country, your fellow man, and Almighty God. 


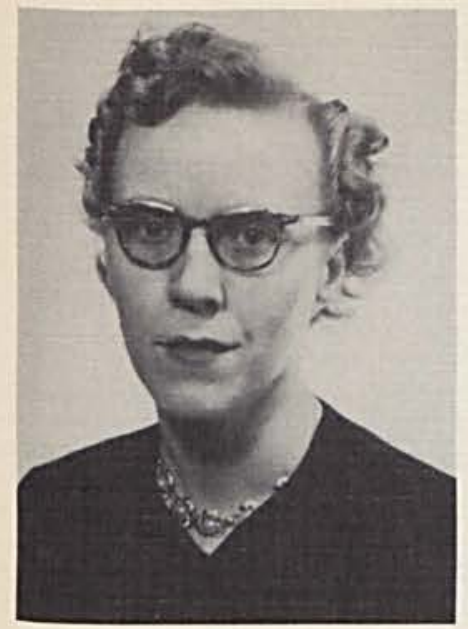

MRS. MCCARTY, Bookkeeper

\section{THE STAFF}

TOM BELLVILLE, Supt. Buildings and Grounds

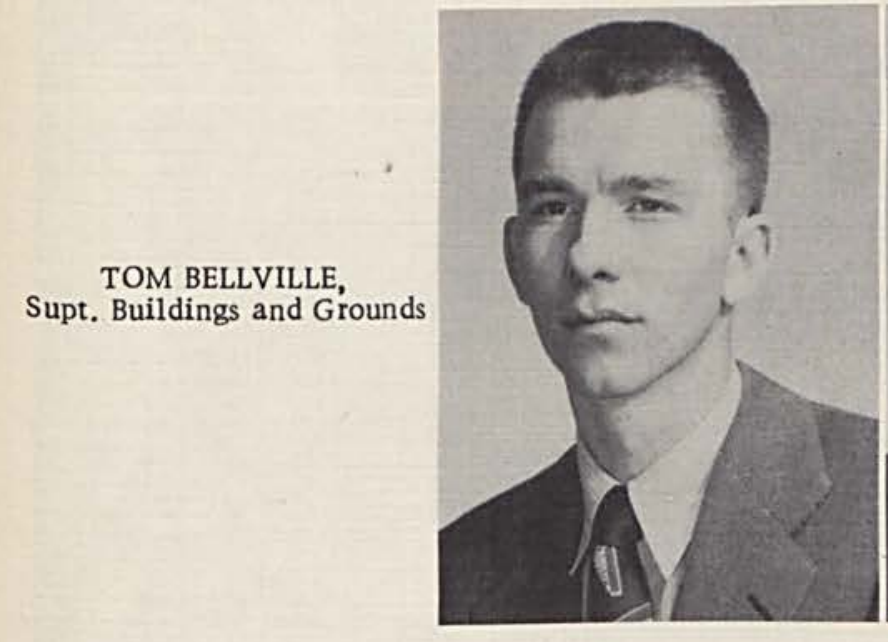

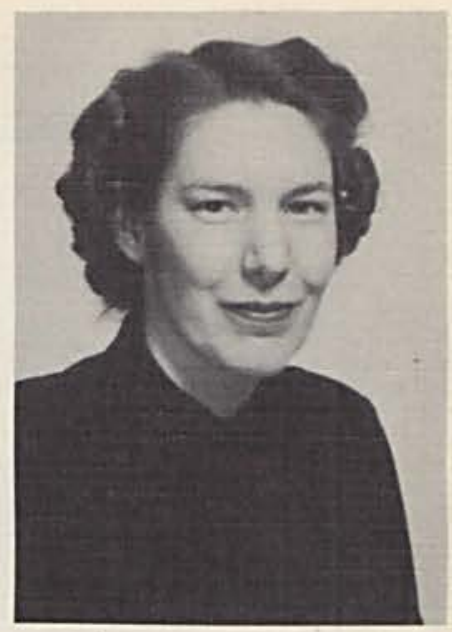

MRS. BRY ANT, Secretary

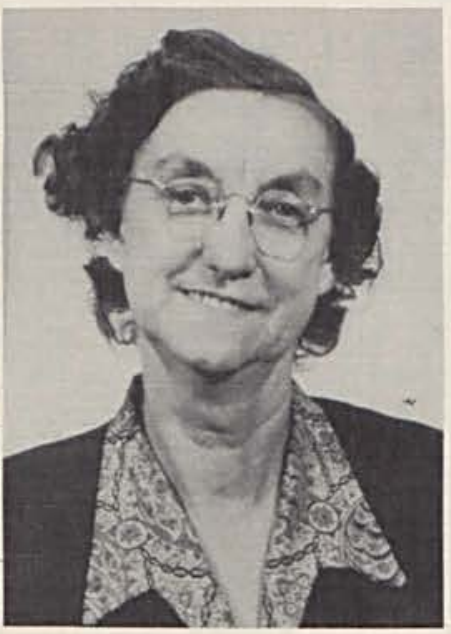

MRS. COTTON, Cook

MISS WILLIAMSON, Librarian

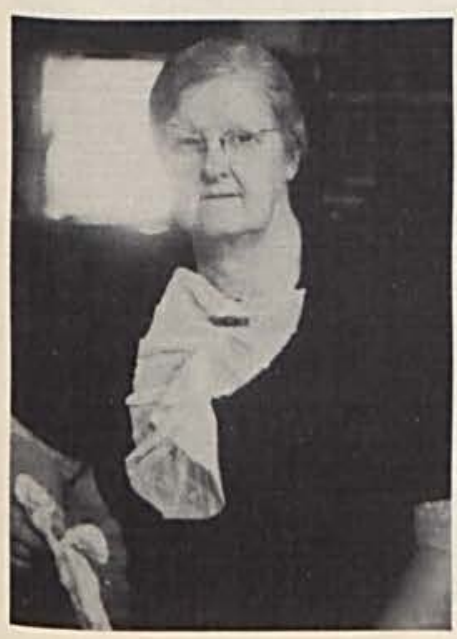

MRS. SPRACKLIN, Cook

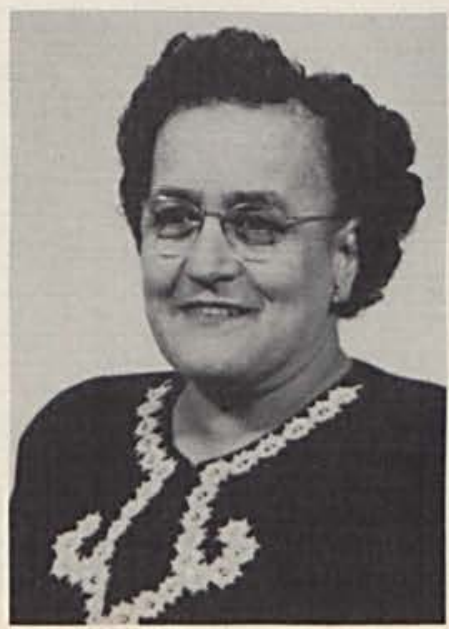

MRS. SINGLETON, Cook

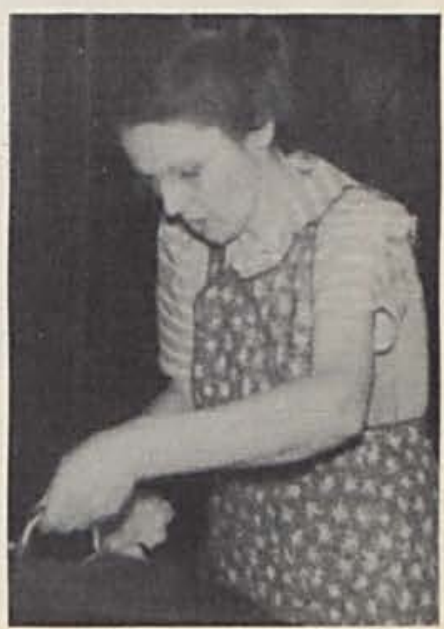



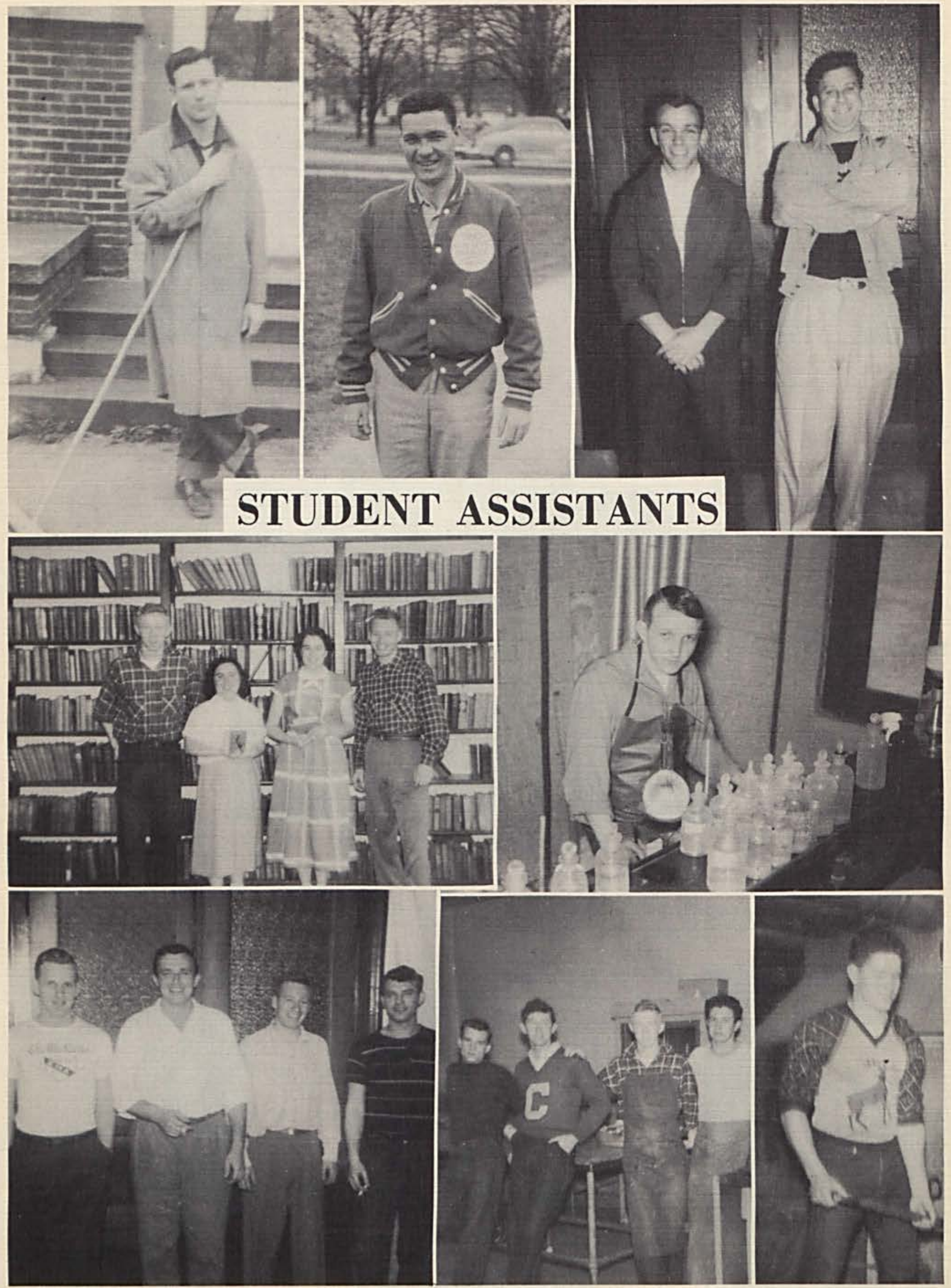


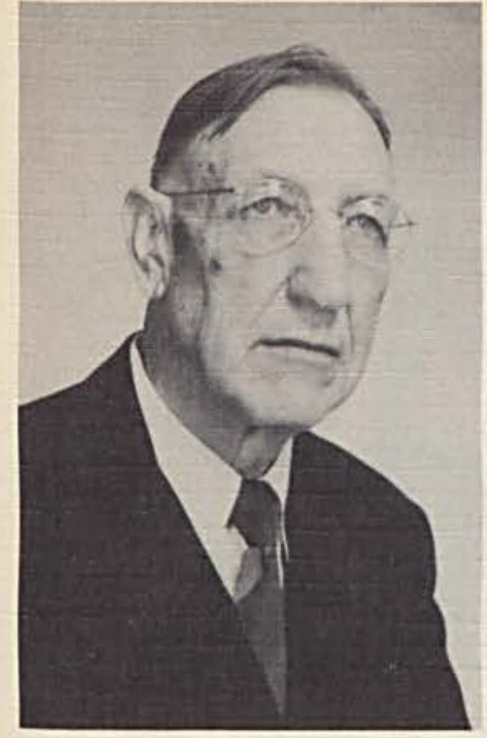

FRANK ALBERT JURKAT, A. B., A.M., LL.D., D. D.Dean of the Seminary and Professor of Foreign Languages.

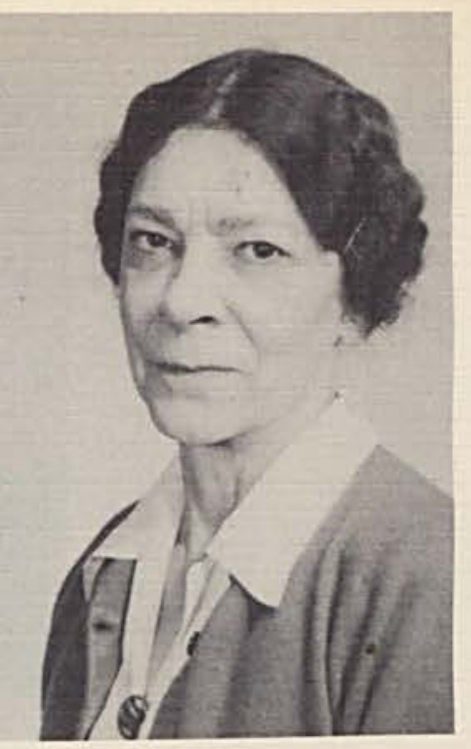

HELEN H. SANTMYER, B. A., B. Litt., Dean of Women and Professor of English.

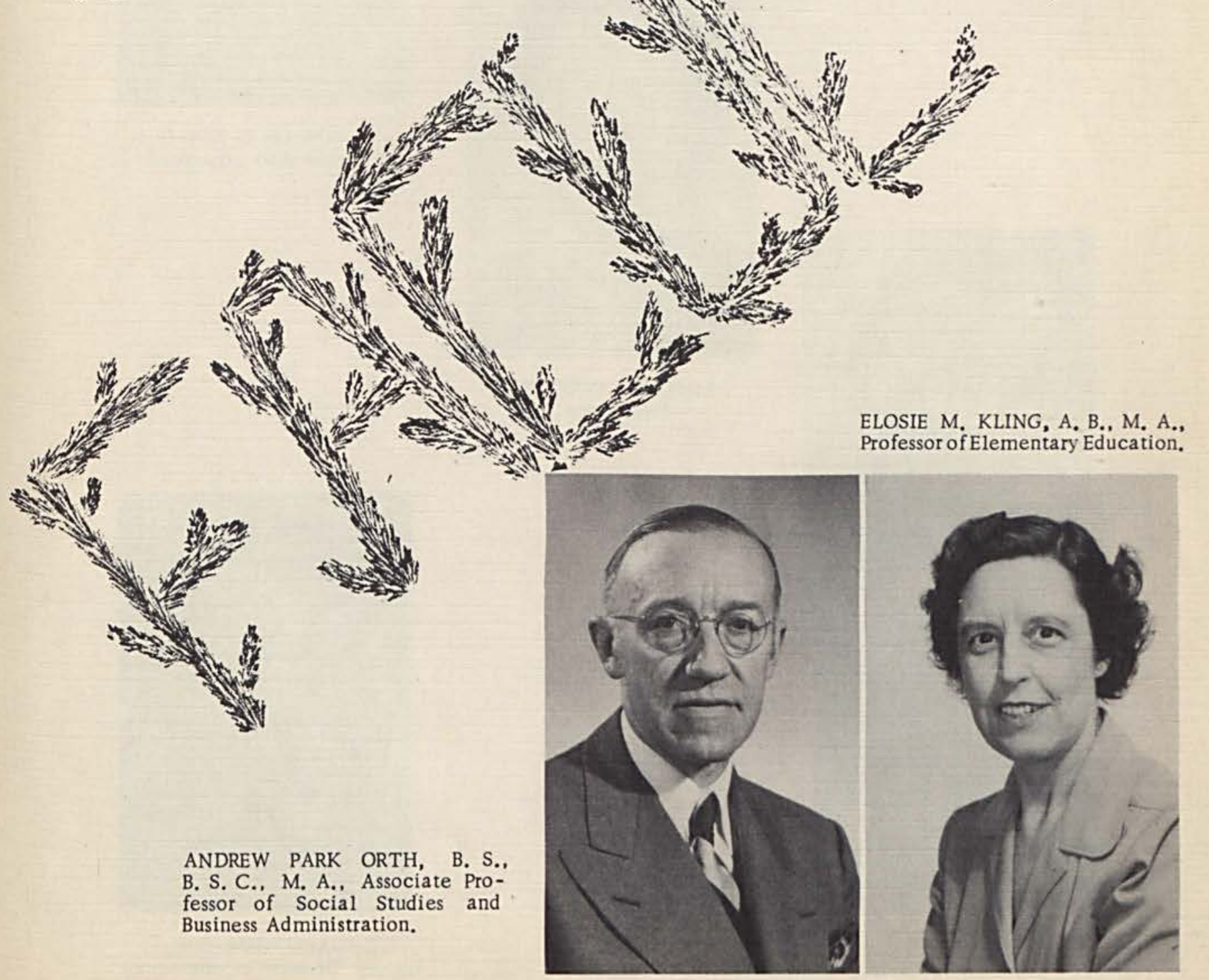




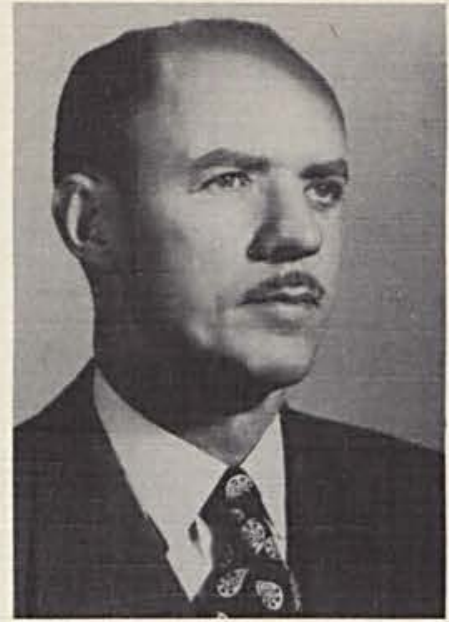

W. ALEXANDER HUNTER, Director of Education

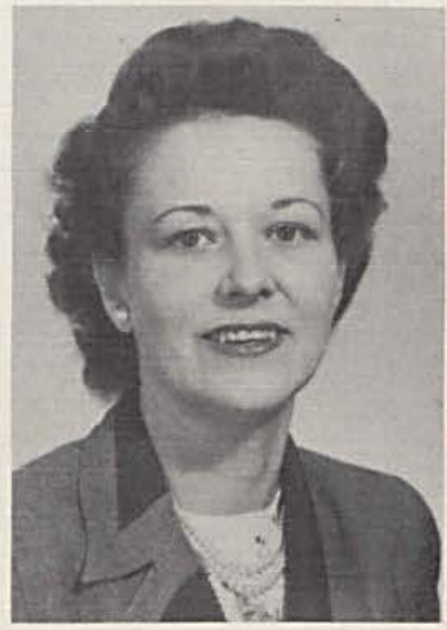

ADELAIDE HUNTER, Physiology

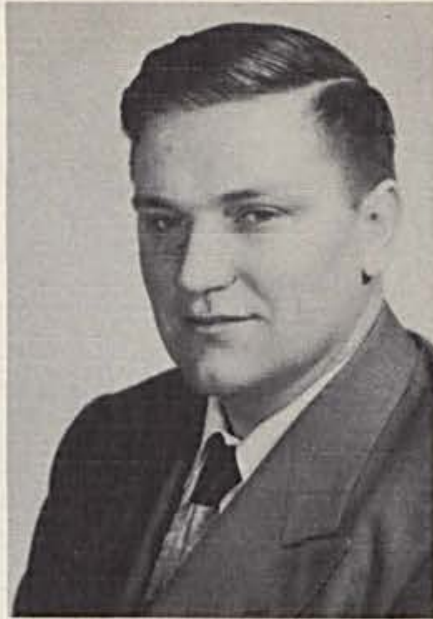

ELWOOD SHAW, Physics, Chemistry

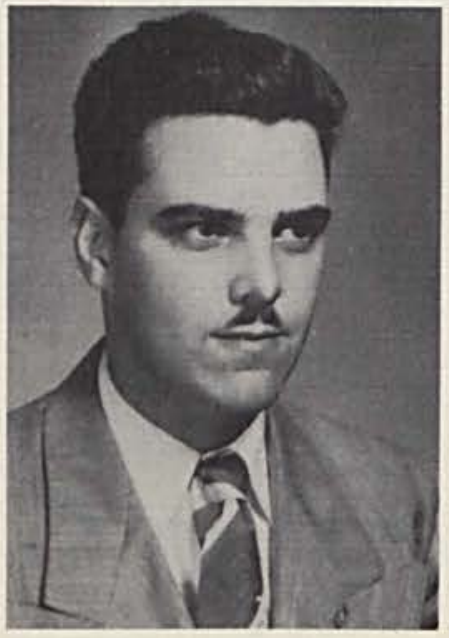

JAMES RAMSEY, Biological Sciences

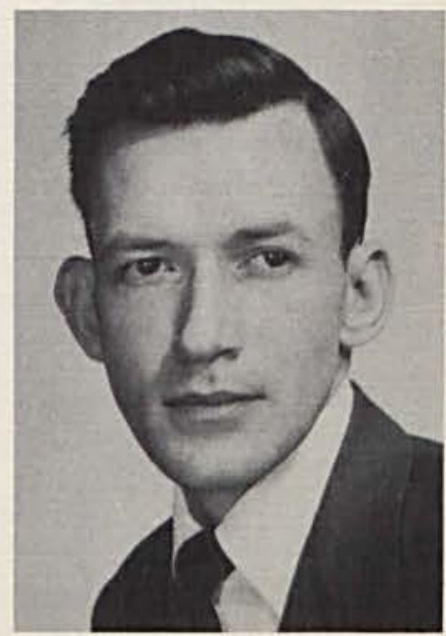

DONALD EDINGTON, History, Director of Admissions 


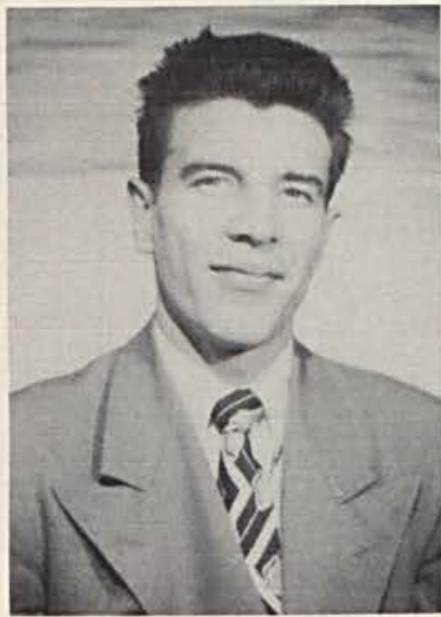

HARRY STELLINGS,

Language, Asst. Coach

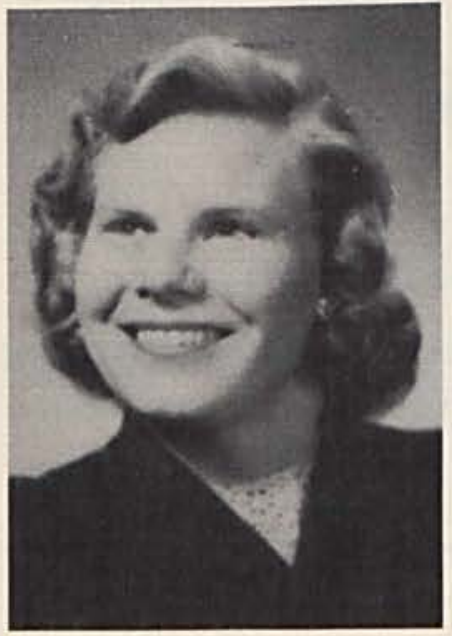

JUNE KYNN,

Phys. Educ.

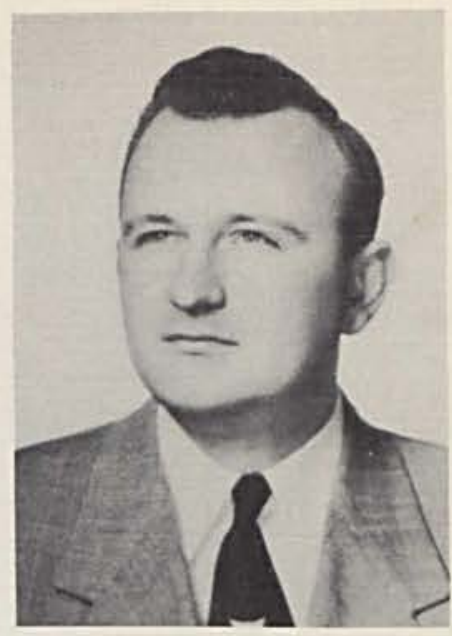

WILLIAM JANSEN, Religion

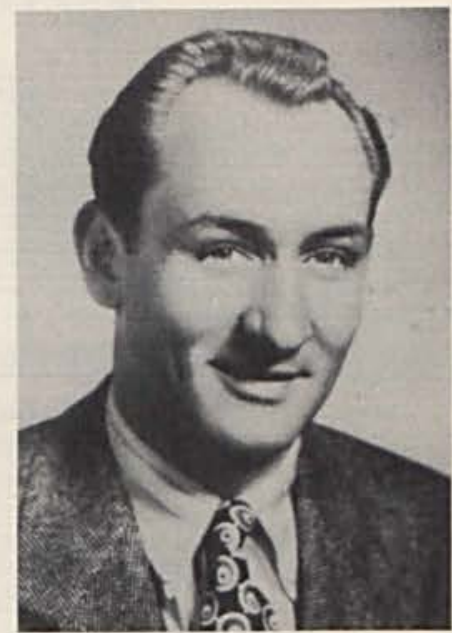

MIKE KYNN,

Phys. Educ. Coach 


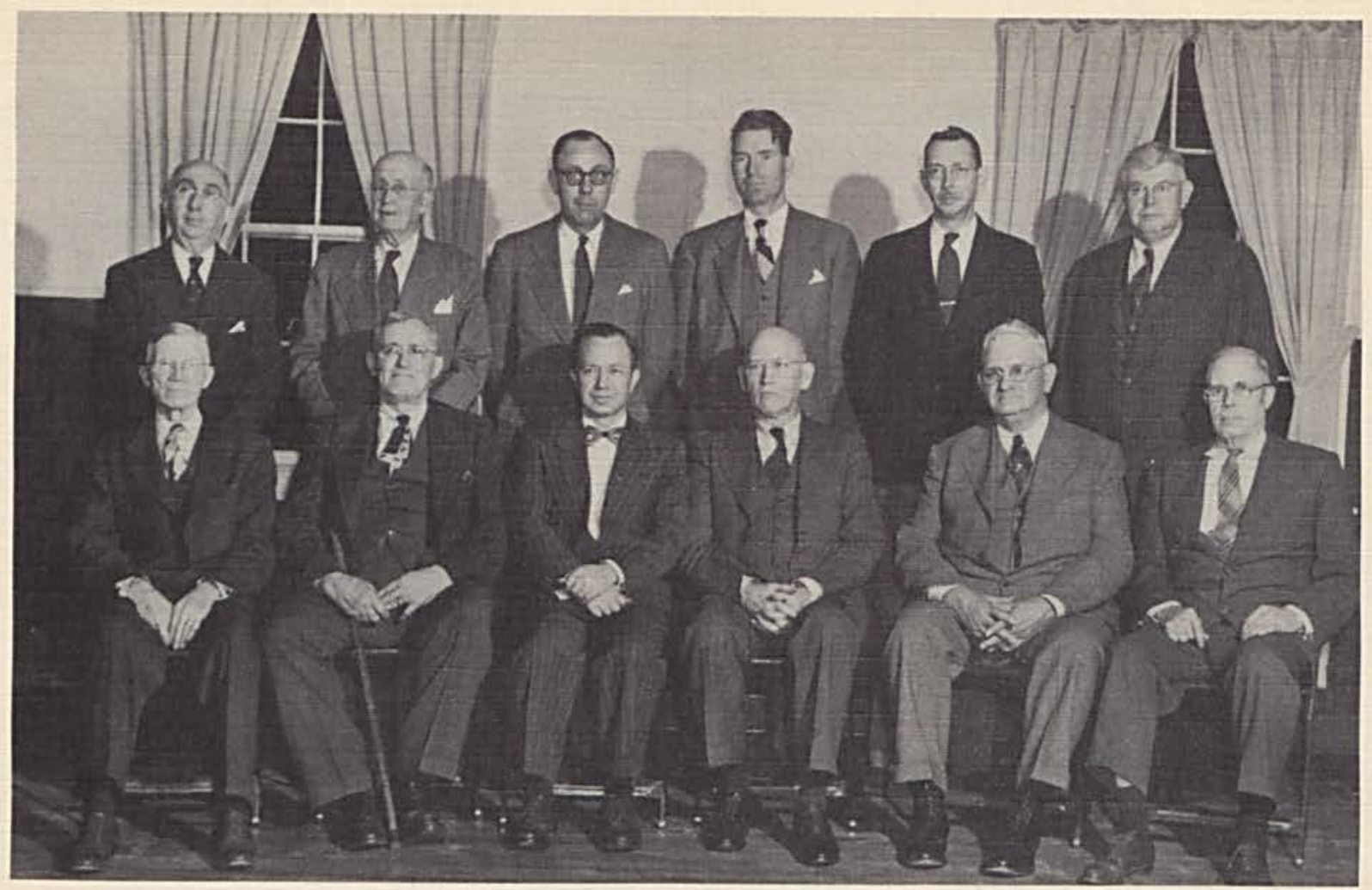

FIRST ROW, LEFT TO RIGHT: Walter C. Iliff, George H. Hartman, Harvey Auld, Joseph A. Finney, Dr. Leo Anderson, Earl McClellan. SECOND ROW, LEFT TO RIGHT: Karh1 Bull, E. H. Miller, Donald F. Kyle, Harold Ray, David Bradfute.

\section{BOARD OF TRUSTEES}

Willard Barlow, Teacher John W. Bickett, D.D., Minister David C. Bradfute, Postmaster Karlh Bull, Retired

Donald F. Kyle, M.D., Physician Rankin McMillan, Farmer Ralph Rife, Farmer

Harvey C. Auld, Banker Leslie S. Dean, M.D., Physician George H. Hartman, Merchant Walter C. Iliff, Contractor Earl McClellan, Merchant Harold Ray, M.D., Physician Dallas C. Marshall, Insurance

Leo Anderson, Veterinarian Leo Deutsch, Manufacturer J. A. Finney, Attorney Max Hobbs, Attorney Walter Linton, Teacher Harold D. Neill, Manufacturer Emeritus

John L. Dorst, Retired

\section{J. A. Finney, '06}

Leo Anderson, D.V.M.

Harvey C. Auld, '29

George Hartman

Edward H. Miller, Acting President
TERMS EXPIRE 1952

Columbus Clifton Xenia

Cedarville

Cedarville

Cedarville

Cedarville

TERMS, EXPIRE 1953

Springfield Cleveland Cedarville Cedarville Xenia

Xenia

TERMS EXPIRE 1954

Xenia

Cedarville Springfield Xenia

Hamilton

Pleasant Hill

Middletown

Springfield

OFFICERS

President V.President Secretary

Treasurer Ex Officio 


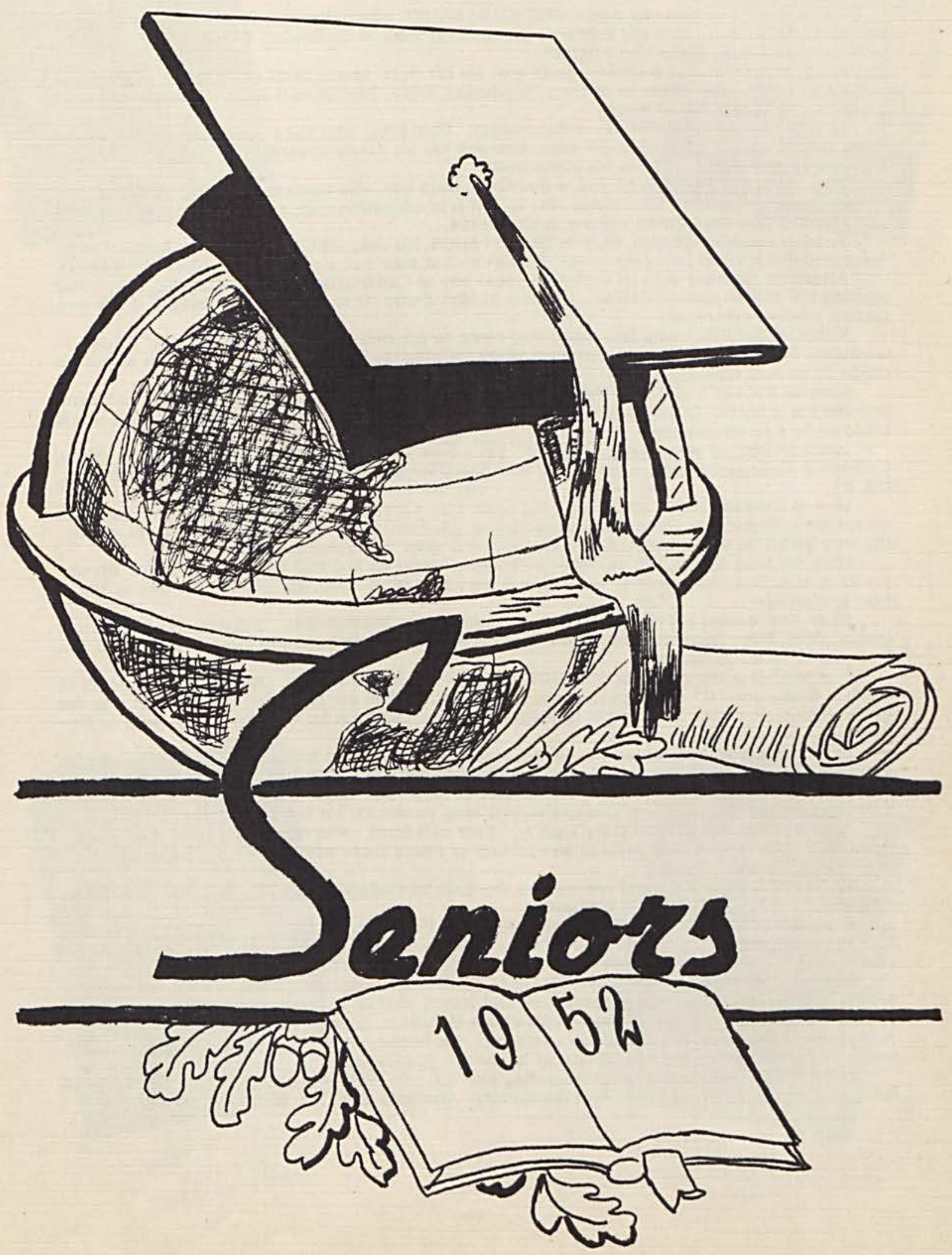




\section{AIMS OF THE CLASS OF "52"}

To begin this account we name ERIC (GUS) BAUTS who hails from New York City. Gus has one main desire in his life and that is to practice his work in Greenwich Villege, N. Y. His liberal arts course may make him eligible.

PAUL DUNN who also chose liberal arts for his field spends most of his time at the local newspaper office. He comes to us from Winchester, Ohio. Paul doesn't want to be much of anything, just to have a lot of money.

Next we have EARL DOWNS, a Portsmouth, Ohio boy, who just cannot stay away from his home town. Earl is registered under education and has his major in math. His main desire in life is to run an airline to and from his home town.

Now is JIM (ST UBBY) WAGNER, a Hamilton, Ohio boy, who came to Cedarville College with the migration of veterans after World War II. Jim is in education with a physical education minor and wants to take Paul Brown's place in Cleveland.

Another from Portsmouth, Ohio is DON STAGGS. His only ambition is to play football with the Los Angeles Rams. Last year it was the Brown's but they had a poor season. (Lost four games). After Don we have BUD GOODWIN a local boy of Cedarville. Bud is an amazing boy; a full supporter of progressive education. His only hidden desire is to transcent the height of our own student teacher supervisor.

VERNON HOOPER, who left Indiana to come to the rich land of Ohio has taught 3 years in secondary School, but still feels he needs more training in the field. His ambition is to get his credit in student teaching.

Next on the list is JIM HARTMAN, another Hamilton, Ohio boy. Jim is enrolled in liberal arts and has a hidden desire to be editor of "Field and Stream" magazine. if this fails Jim would settle to be a beach-comber.

JOHN SYREC, a Washington, Pa. boy has a lone ambition of becoming the coach of the Cedarville College baseball team. Along with this John is quite an English student. (Old English,
this is).

Now to mention DAVE SPITZER, a lad from Tipp City, Ohio. Dave has a B. S. in Educ. with his major in Physical Science. Dave would leave this field for a coaching job back in Tipp City. His only ambition along with this is a son who will grow up to play football.

Here we have KENNETH WOODS, a Pittsburg boy. Ken is a real Historian at heart. His desire is to visit France as some of his friends have come from there. He may do just that as Uncle Sam is after him.

After Ken comes DAVE KING, also a progressive education man at heart. He hails from Lorain, Ohio. Dave wants to settle down, and his prospects have been narrowed to one. After this Dave wants to teach Biology.

One to always remember is KENNETH CARPENTER from Fairborn, Ohio. Ken is president of the "C" Club, the "C" meaning Confarrs Pantry. His desires are many but the one that tops the list is women. Someday he may get to Hollywood. Ken also feels he is in the wrong field as Biology has now captured his interest.

BET TY YIEDER, who came to us from Canterberry College in Indiana has as a main desire to settle down, but fast. Her field is also narrowed to one, they both like the new "Olds."

Now we have HOMER BURTON, Homer left us for awhile to get a wife and baby but now he is back again and going strong. Cedarville will long remember his football playing.

After Homer is JIM TRINKLE ("speedy," they call him), who ran rings around the boys in

basketball. Jim is also from Indiana and intends to return there with a wife. He wants to coach in a small college.

JOHN ENGLISH is the quiet one seen in the halls of Cedarville Elementary. John is quite an educator, he wants to remain at Cedarville.

Next comes VERON FRANCIS, who hails from Versailles, Ohio. His goals in life are few, only to be left alone by people who think he needs more rich experiences in his field. On his second choice Vernon would settle for a professorship here at Cedarville.

Near the end of the list we have CHARLES THOMAS, from Troy, Ohio. Charles is quiet in nature, and all he wants to do is leave here and travel, that is, if someone pays his way.

Last is RICHARD EVANS, who dosen't claim Hamilton, Ohio as his home. Dick would like very much to debate with some of his educators. His hidden desire is to have a son. The darkroom walls are adorned with the results of his hobby, photography.

So ends this work on the students leaving old "CC" in 1952. May they be long remembered for their cooperative work along with the faculty. Also may their trip be long and happy. 

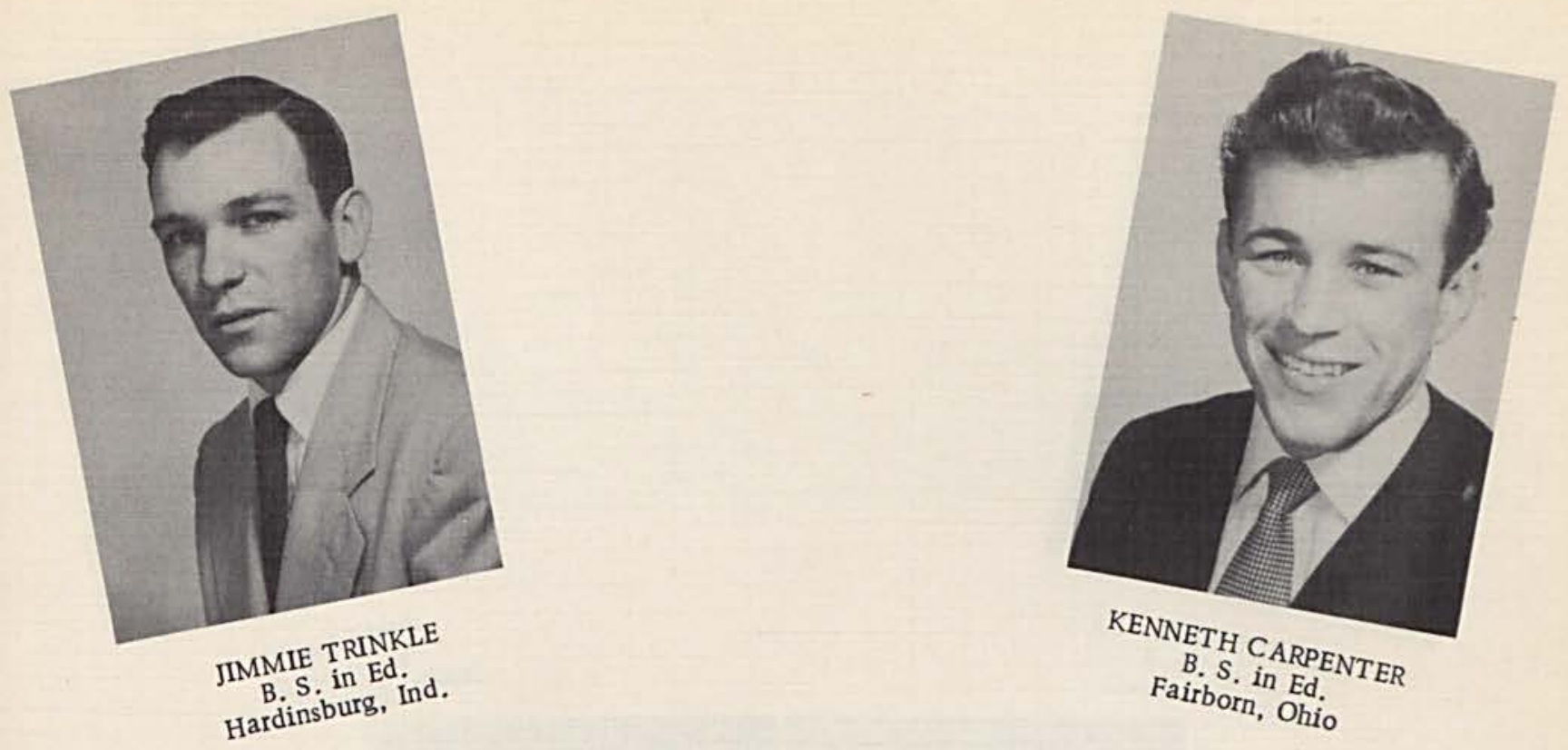

\section{"52"}
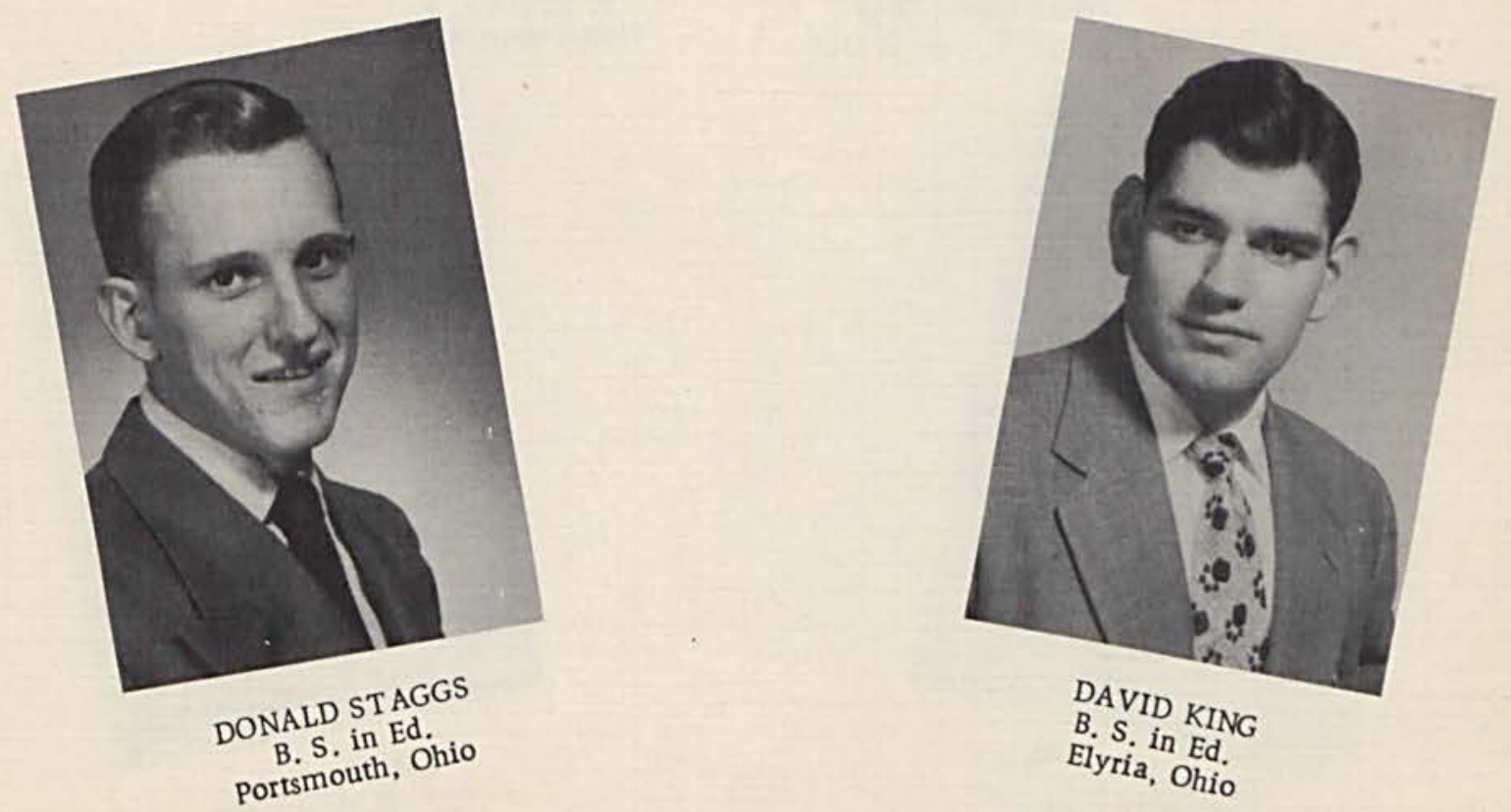

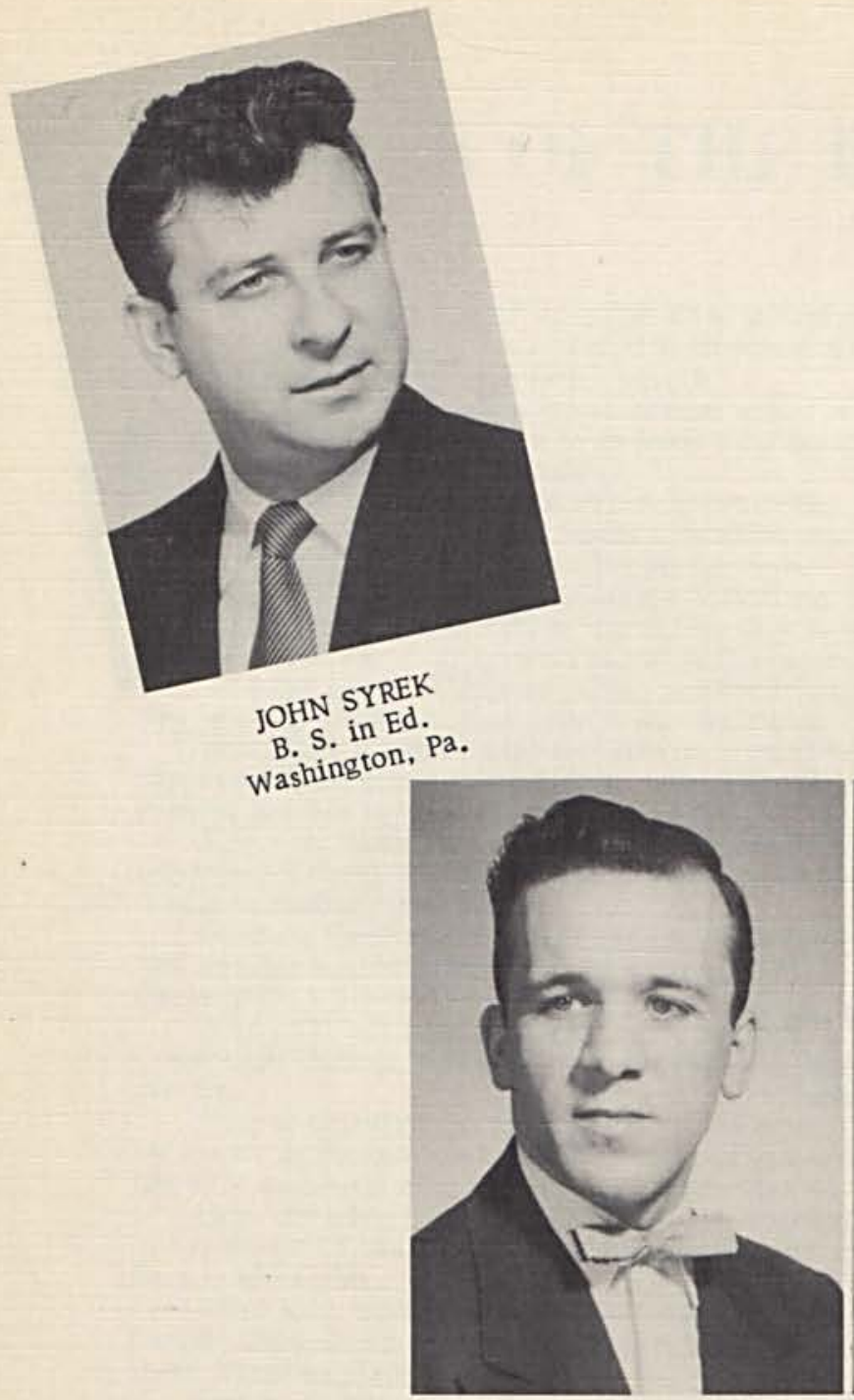

PAUL DUNN

Winchester, Ohio
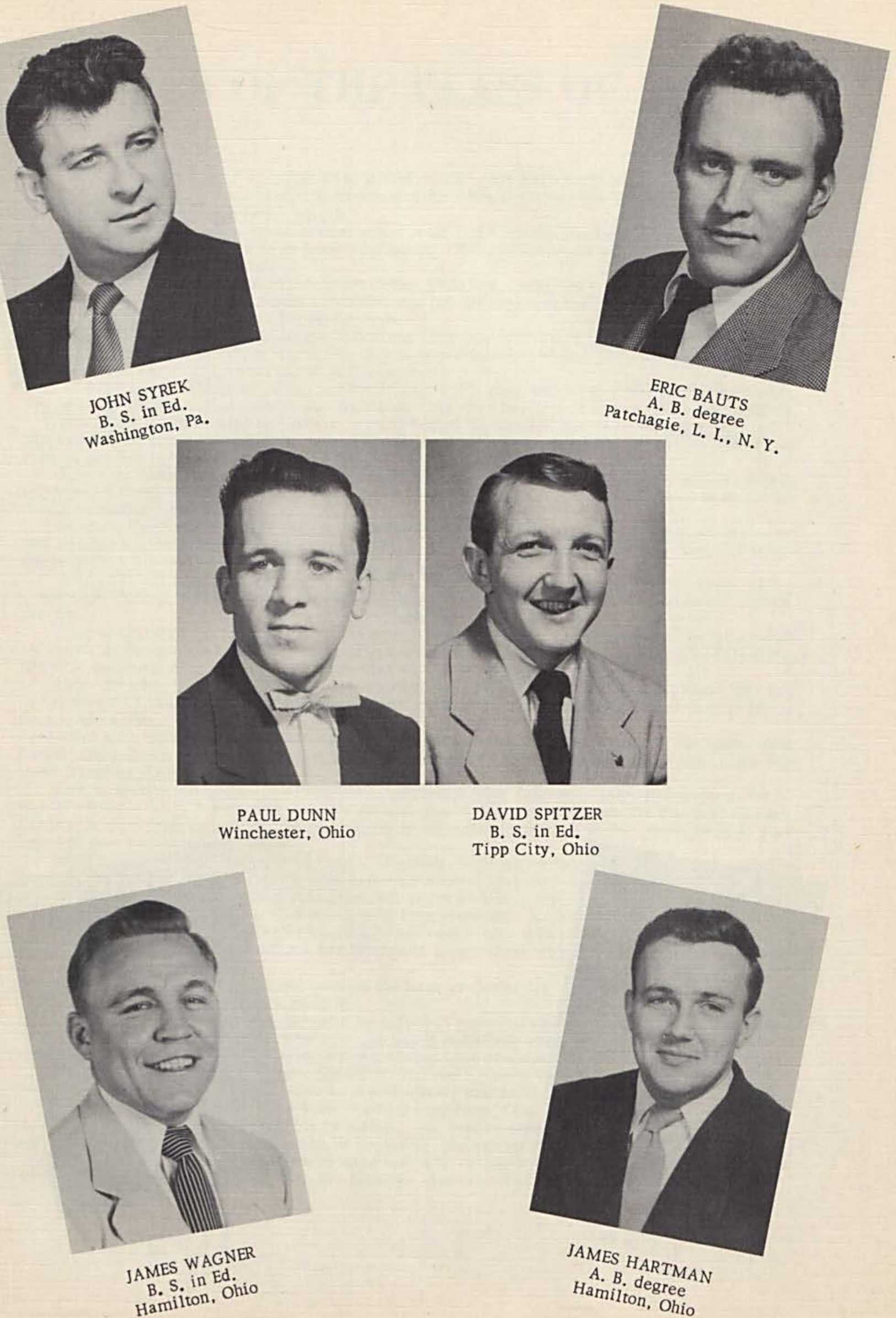

DAVID SPITZER

B. S. in Ed.

Tipp City, Ohio

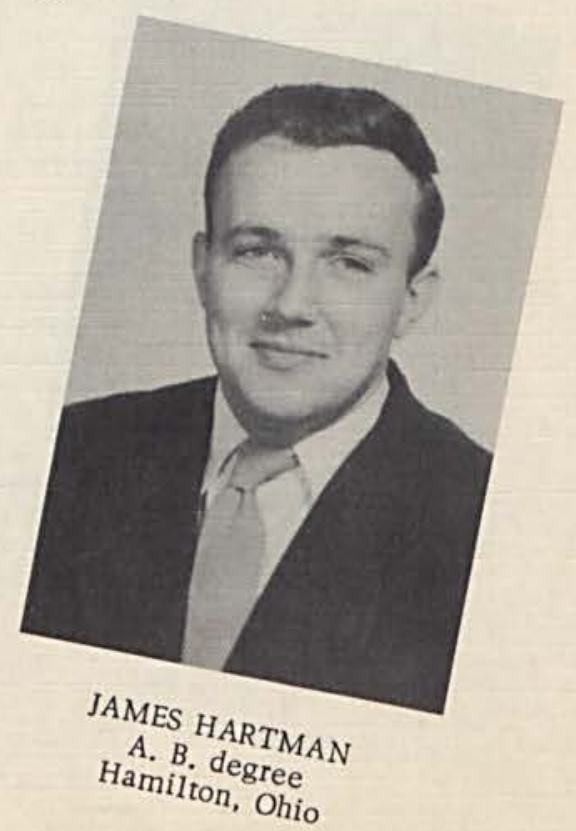



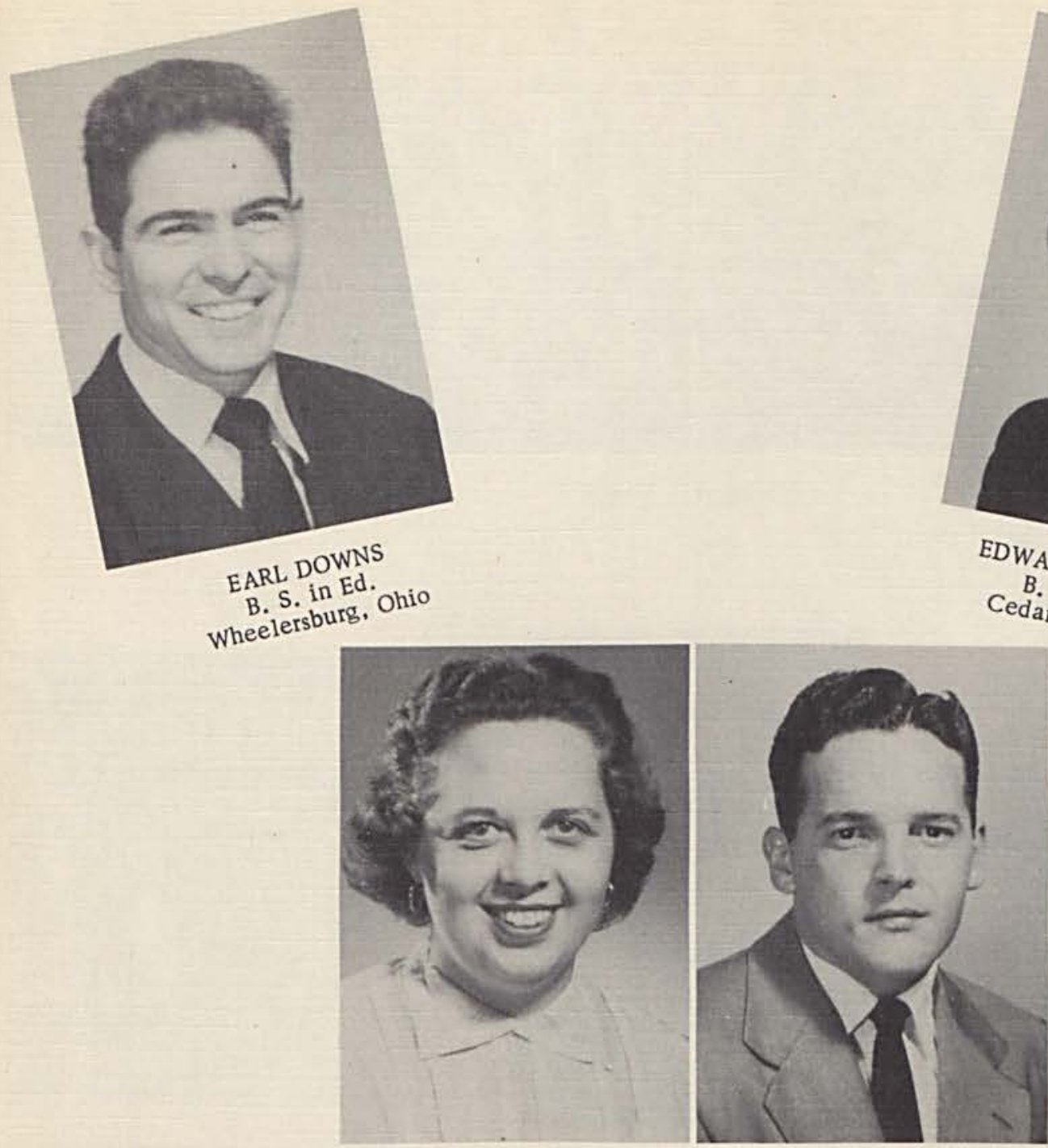

BETTY YEIDER

B. S. in Ed.

Greenfield, Ind.

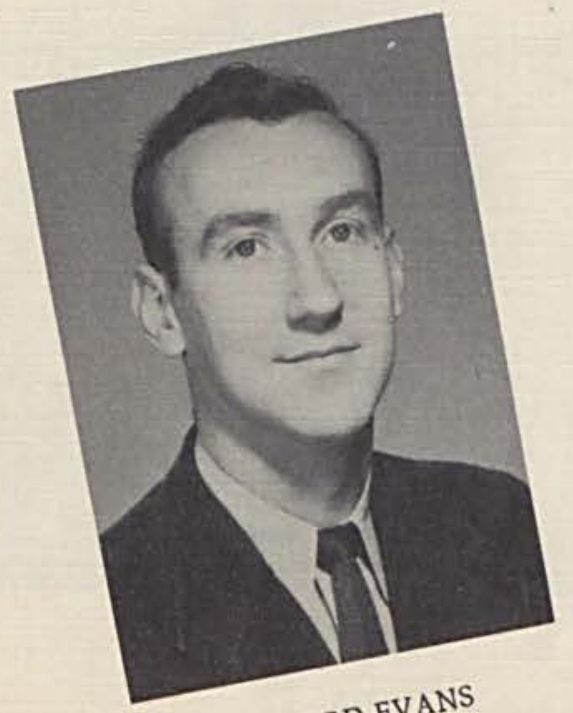

RICHARD EVAN

B. S. in Ed. Ohio Hamilton, Oh

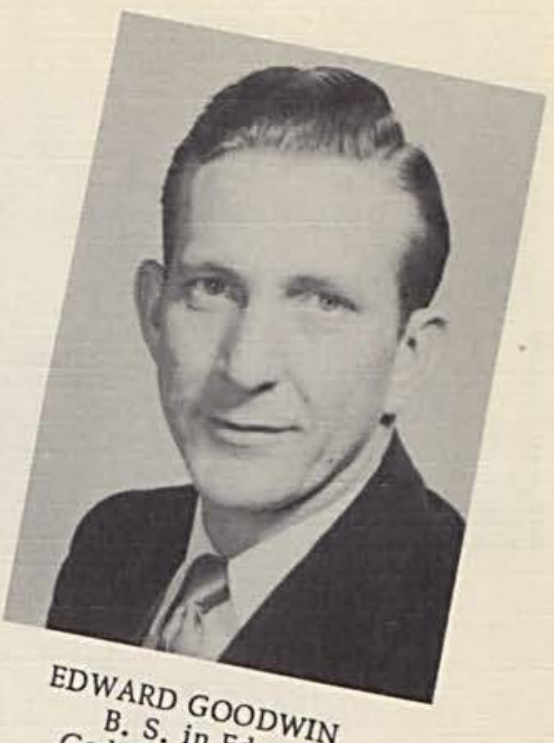

Cedarvilin Ed. ille, Ohio 

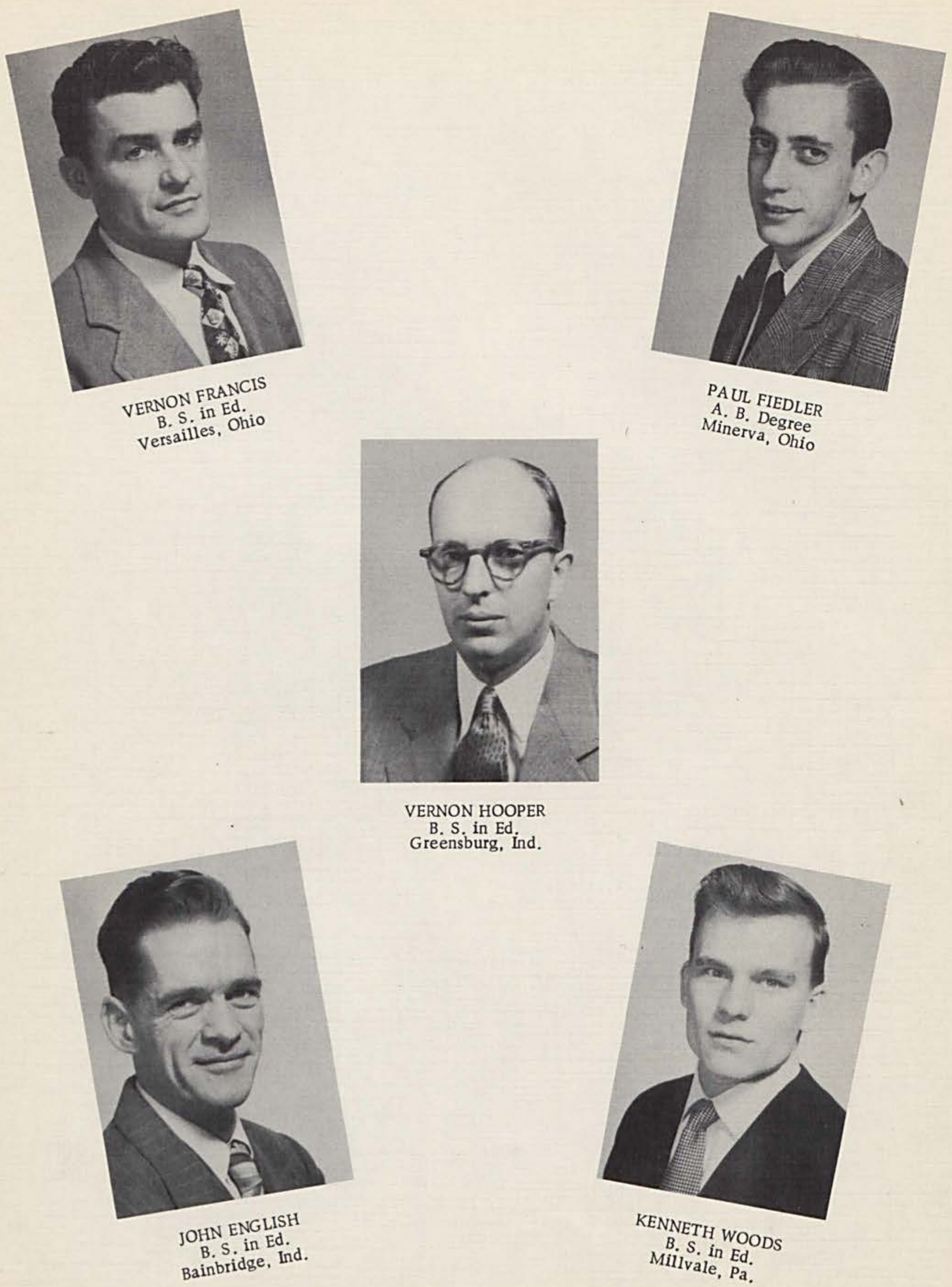

VERNON HOOPER

B. S. in Ed.

Greensburg, Ind.

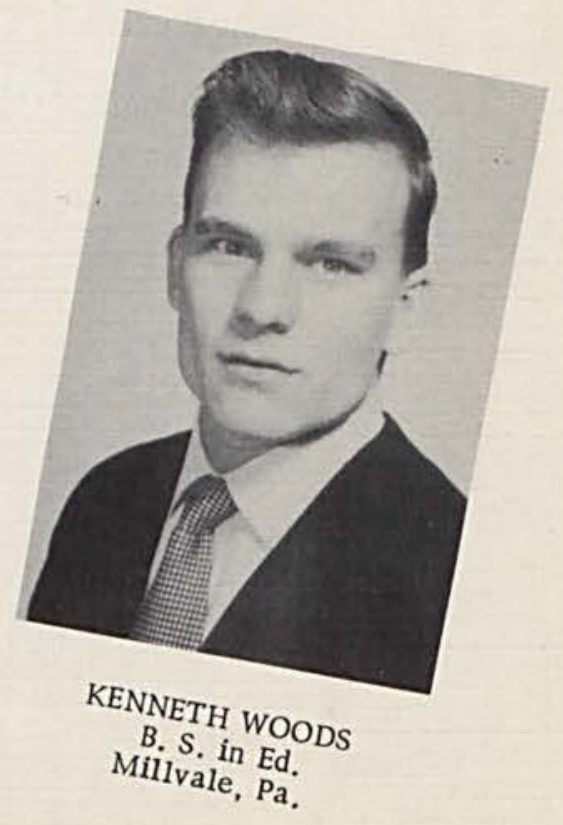




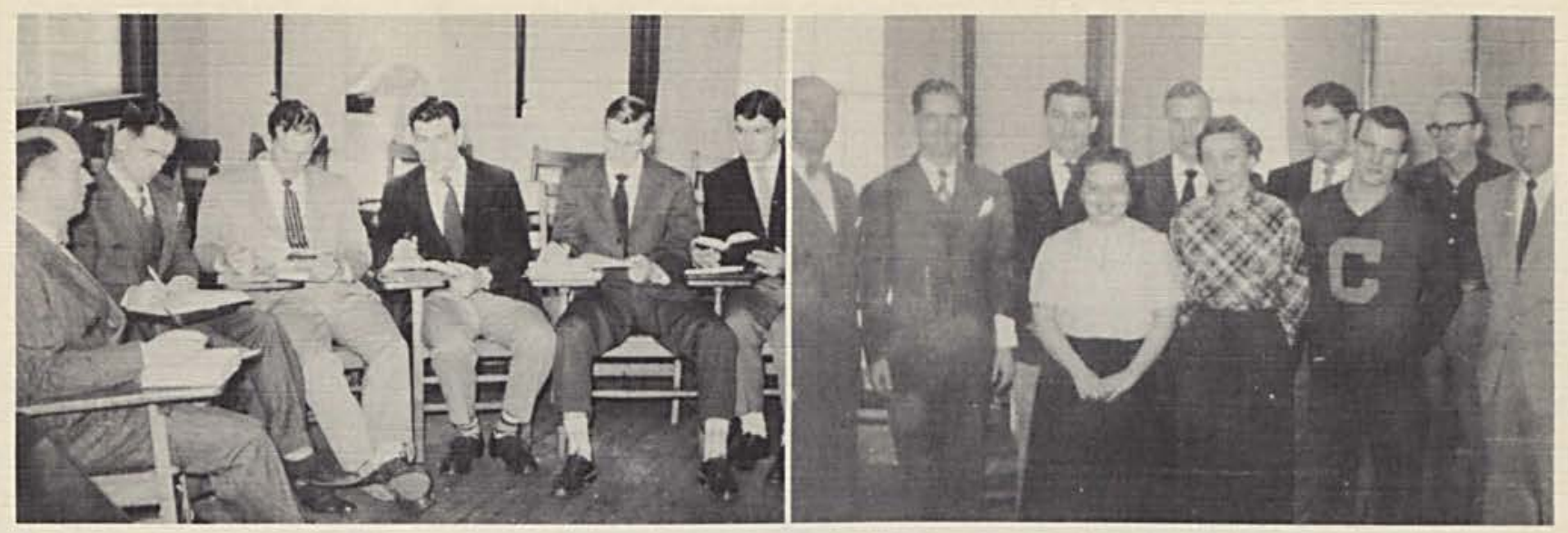

Practice Teachers

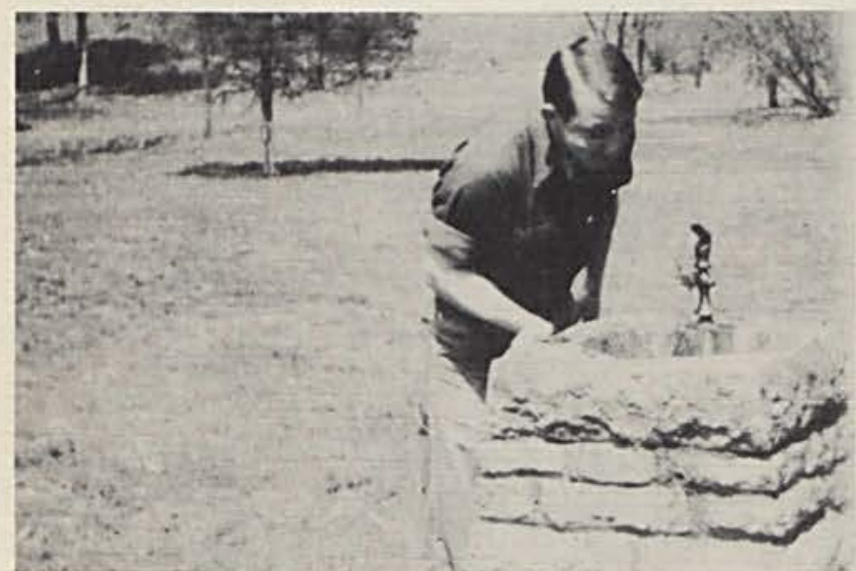

Thirsty

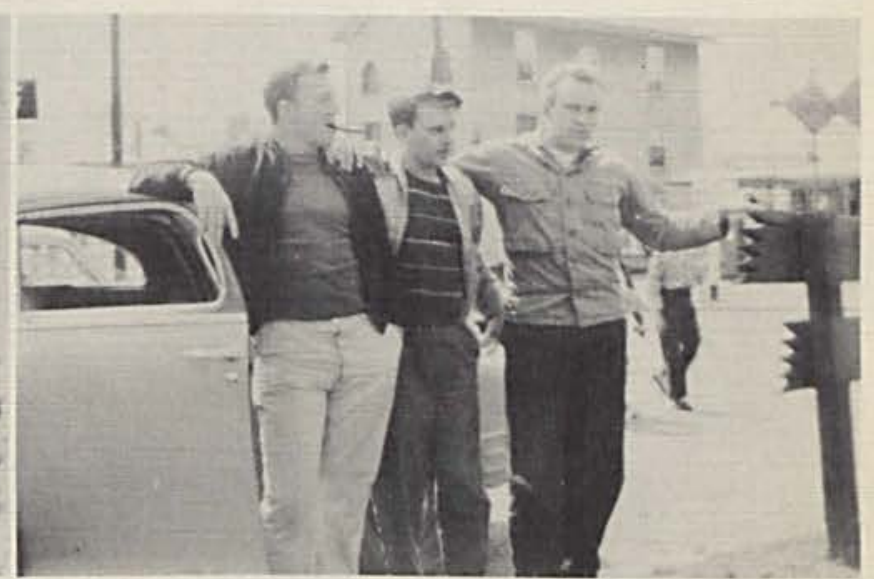

Time Out

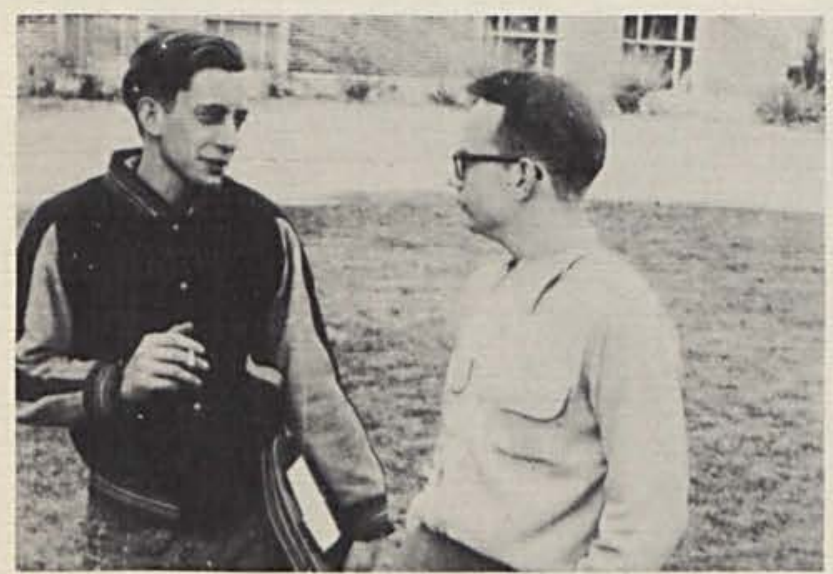

Friendly Chat

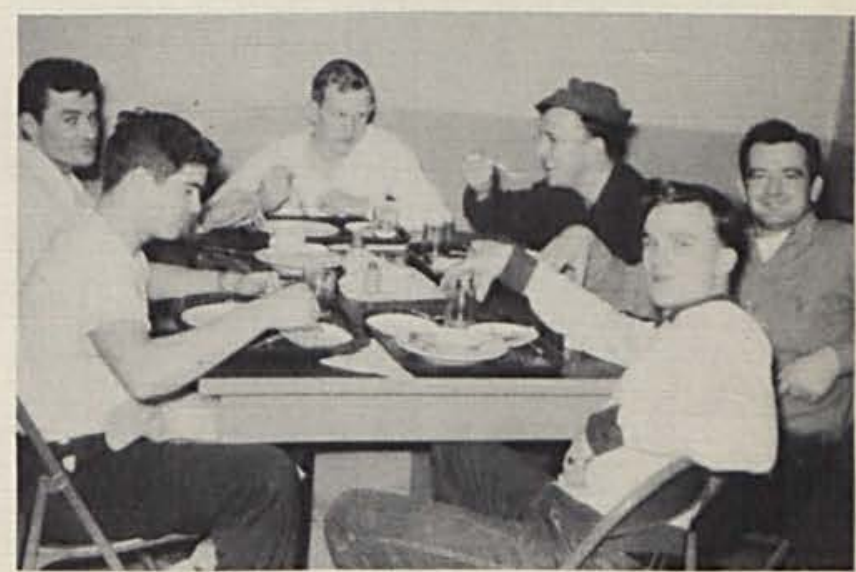

Chow Time 

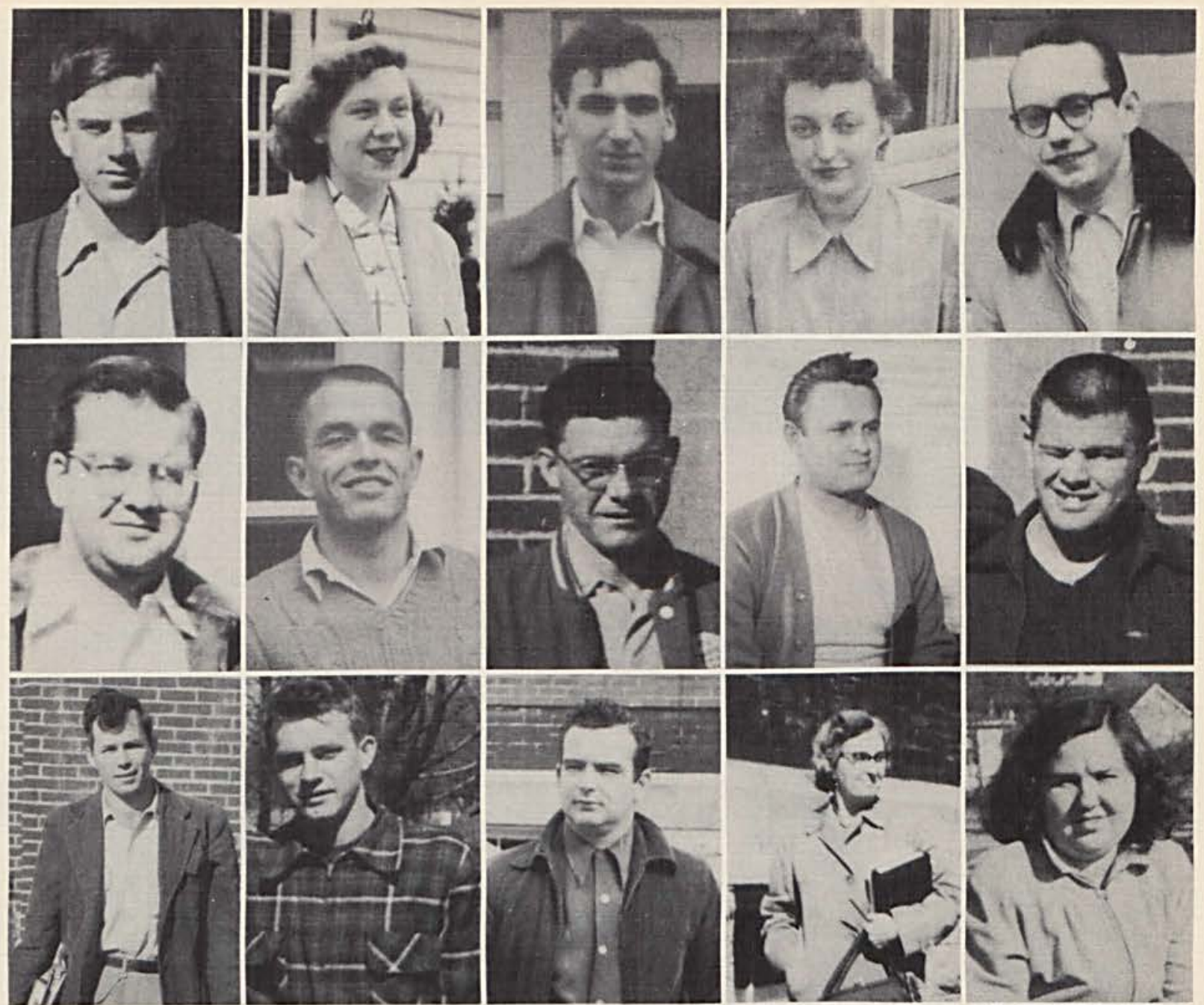

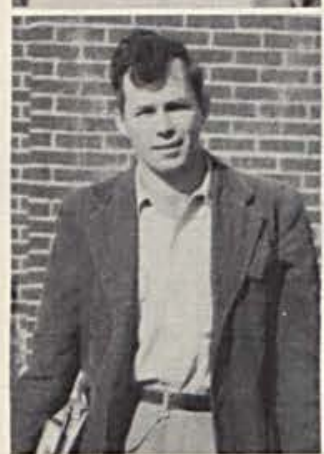

Bill Fife Cedarville, Ohio William R. Albright Sprigfield, Ohio Arthur Kaltenback Dayton, Ohio
Nancy Guilfoyle Manchester, Ohio Stanley Richards Dayton, Ohio Richard Syrek Washington, $\mathrm{Pa}$.

Elizabeth Moore Bedford, Indiana

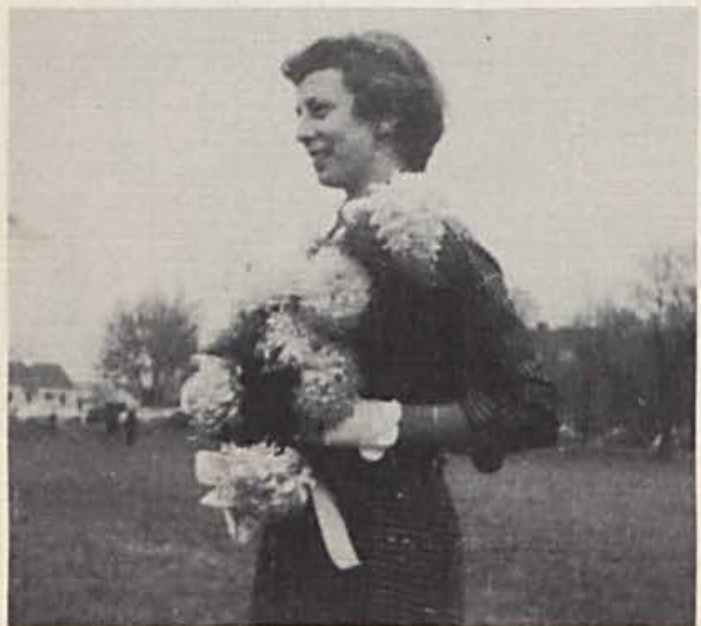

Eddie Brill

Jamestown, Ohio Marlin McClure South Point, Ohio Edward Kurs Hamilton, Ohio
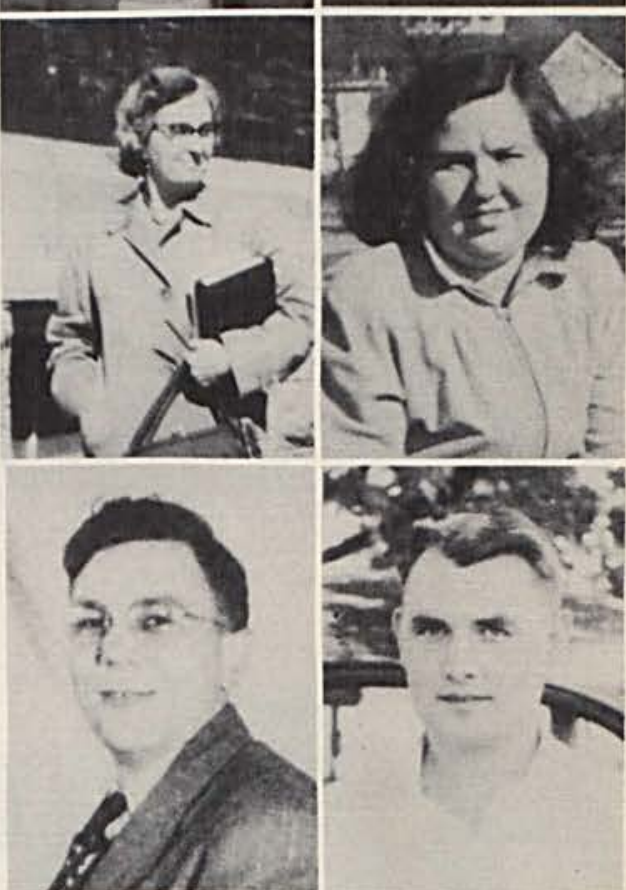

Mary French Jeffersonville, Ohio Harry Schultz Washington, $\mathrm{Pa}$. Pauline Powers Cedarville, Ohio Joseph Price Lilly Chapel, Ohio
Thomas Still Newark, Ohio John Spichty Spring field, Ohio Glenna Anderson Spring field, Ohio

Robert Miller Cedarville, Ohio

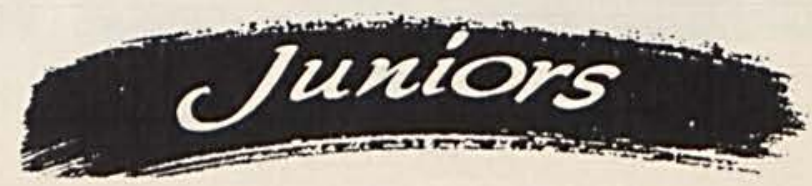




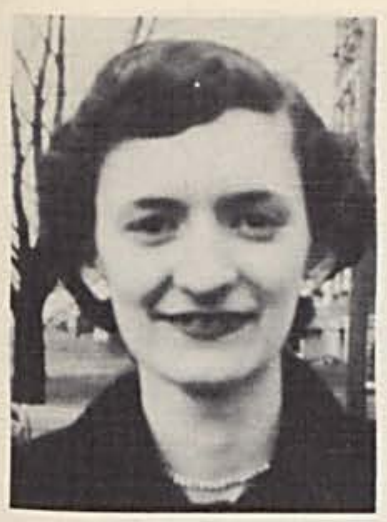

Ann Huffman Cedarville, Ohio

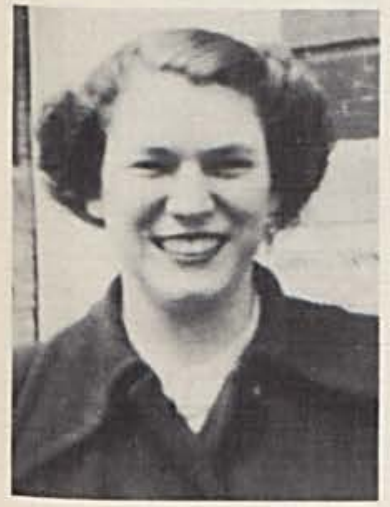

Rebecca Creswell Cedarville, Ohio

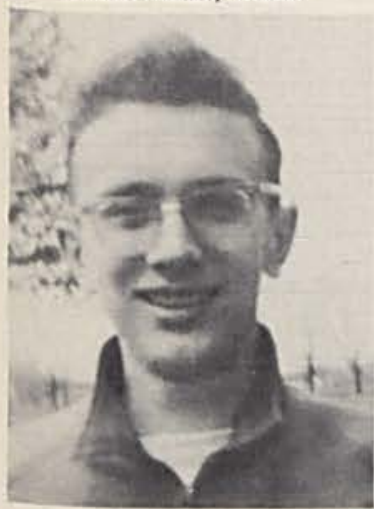

Roger Mann Spring field, Ohio

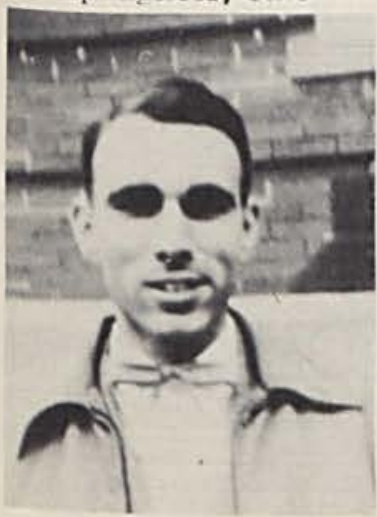

Frank Muller

Spring field, Ohio

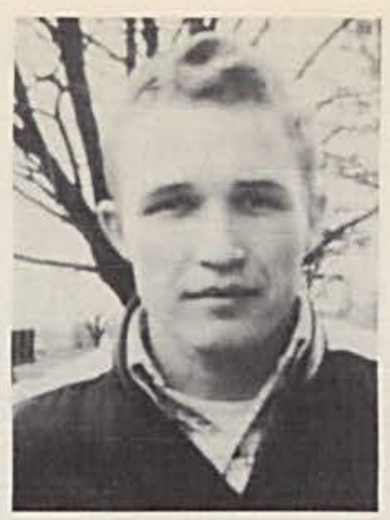

Melvin Tackett Cedarville, Ohio

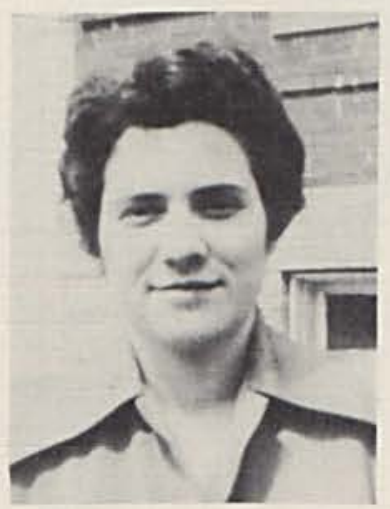

Naomi McNeal Dayton, Ohio

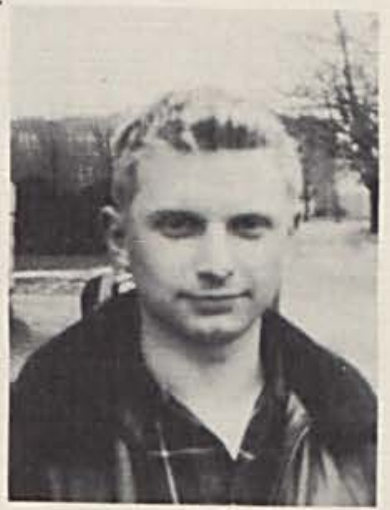

James Luttrell Cedarville, Ohio

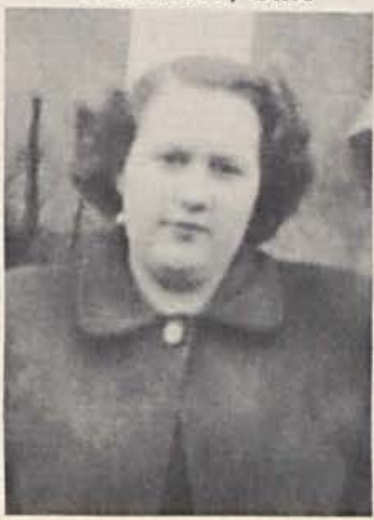

Marcelyn Girnus Urbana, Ohio

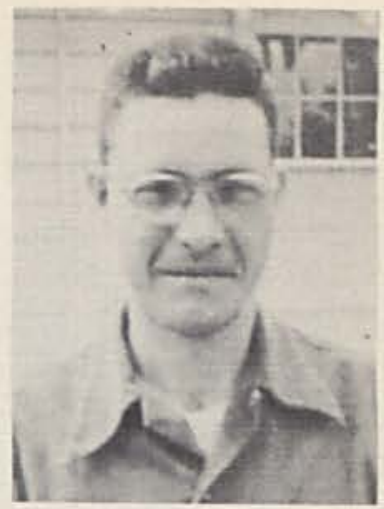

Marlin McClure South Point, Ohio
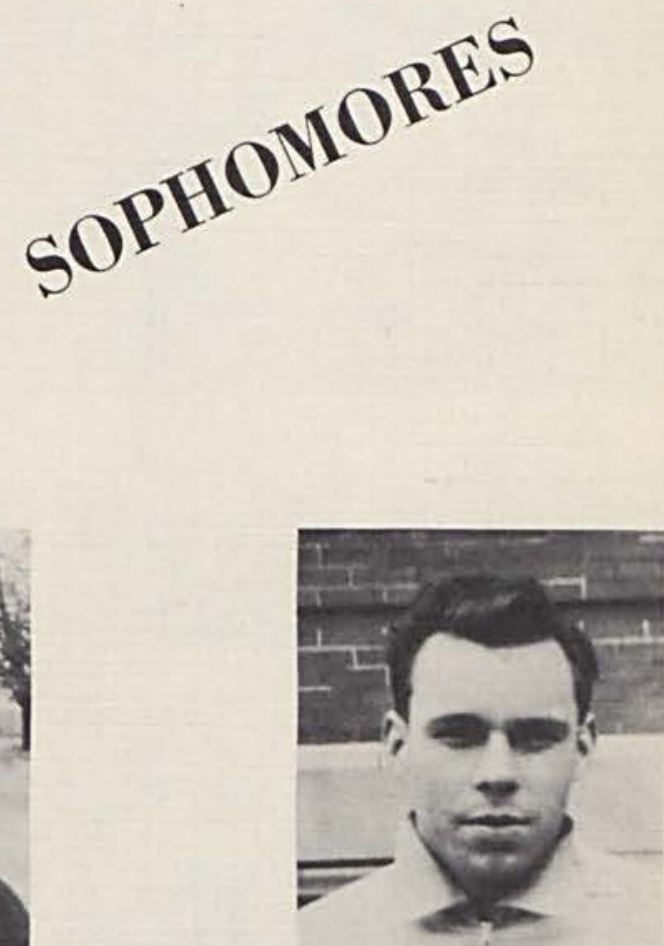

Elwood Lewis

Poughkeepsie, New York

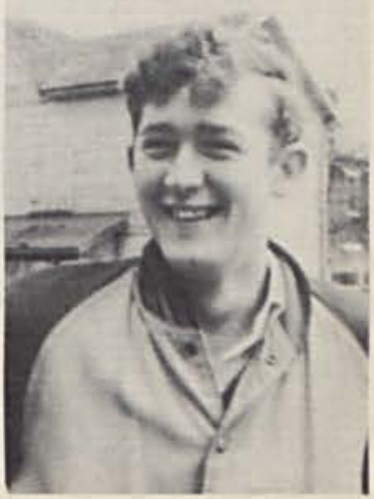

David Farmer

Hamilton, Ohio 


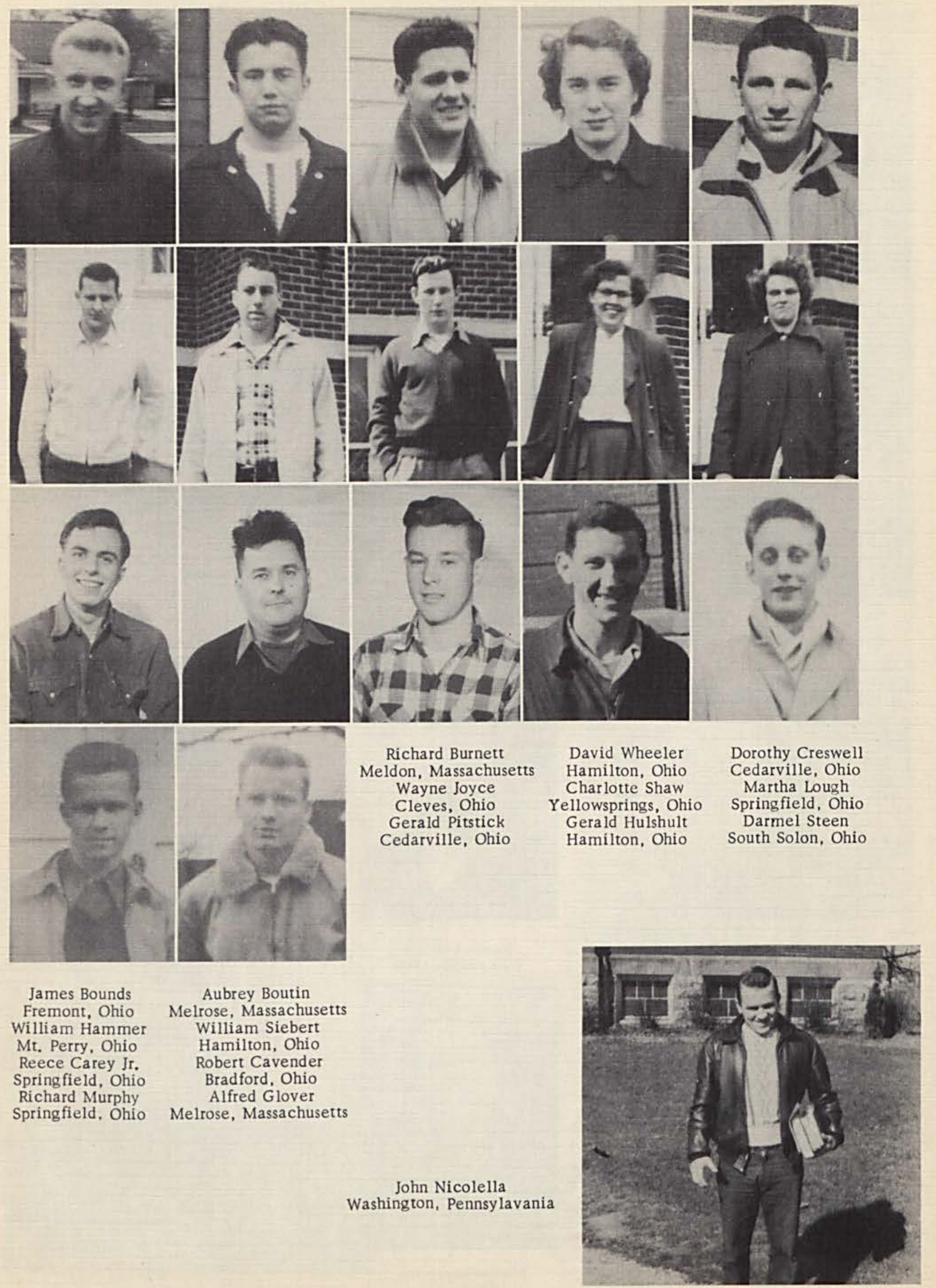



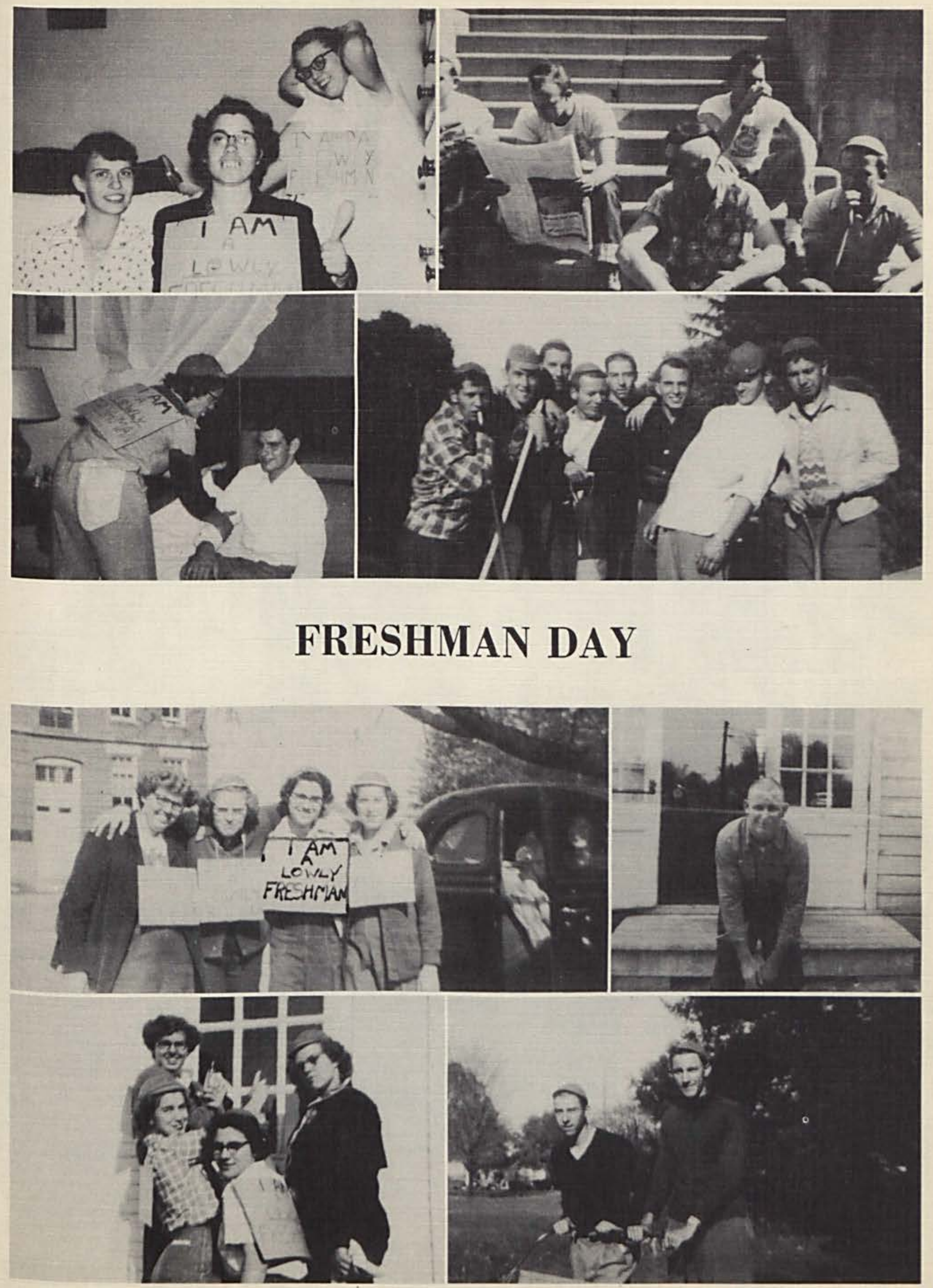


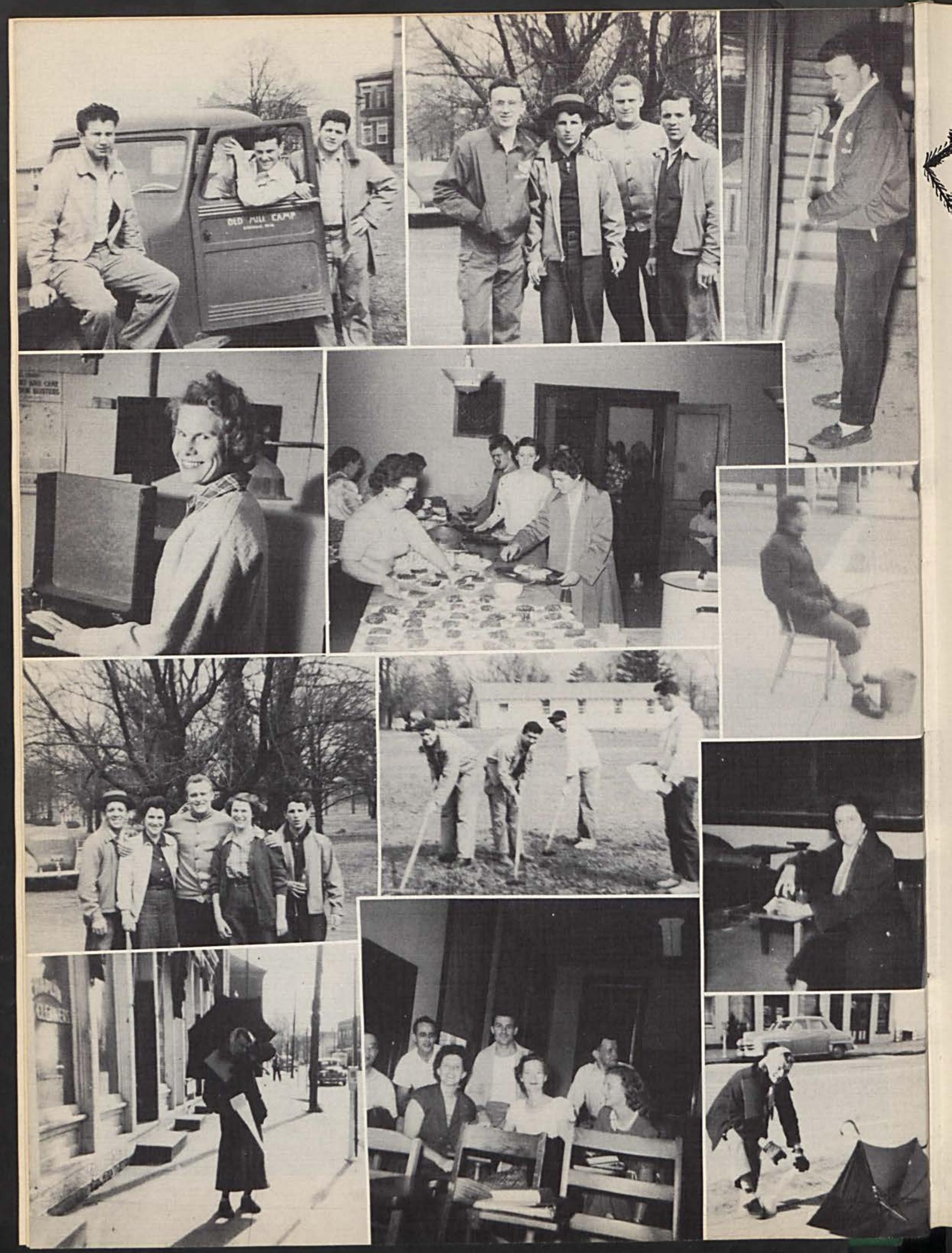




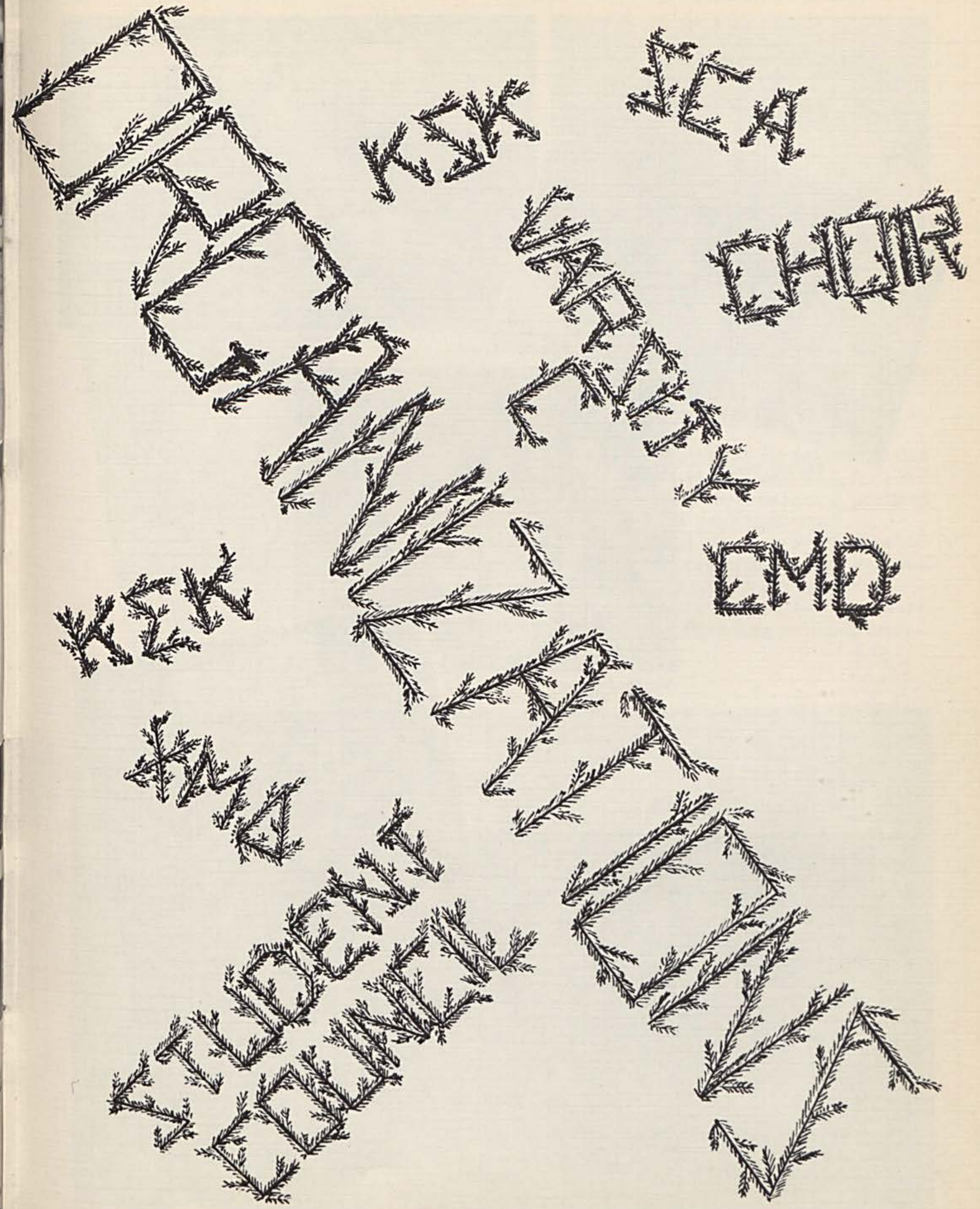




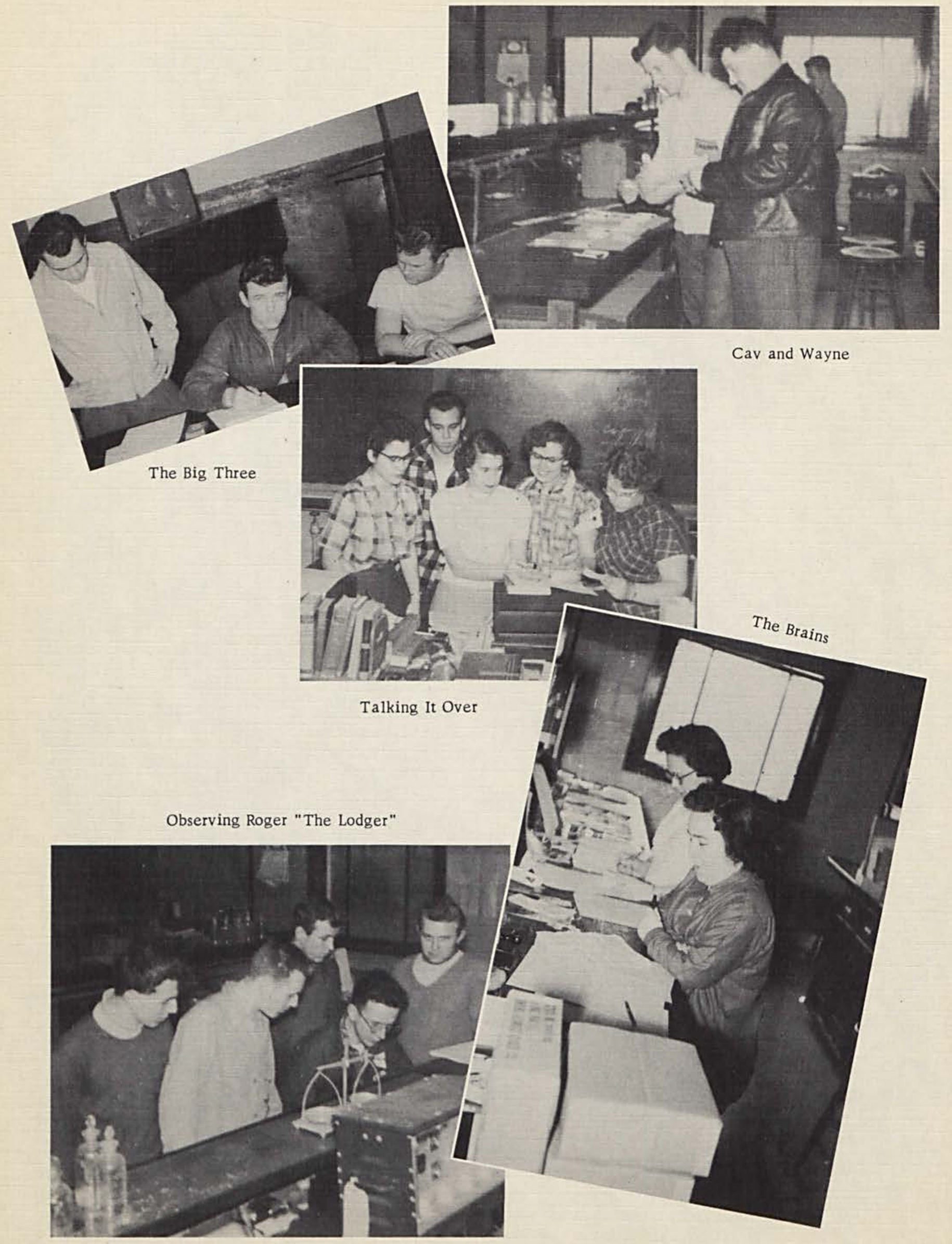




\section{TIME OUT FOR LUNCH}

Betty Yeider, Editor

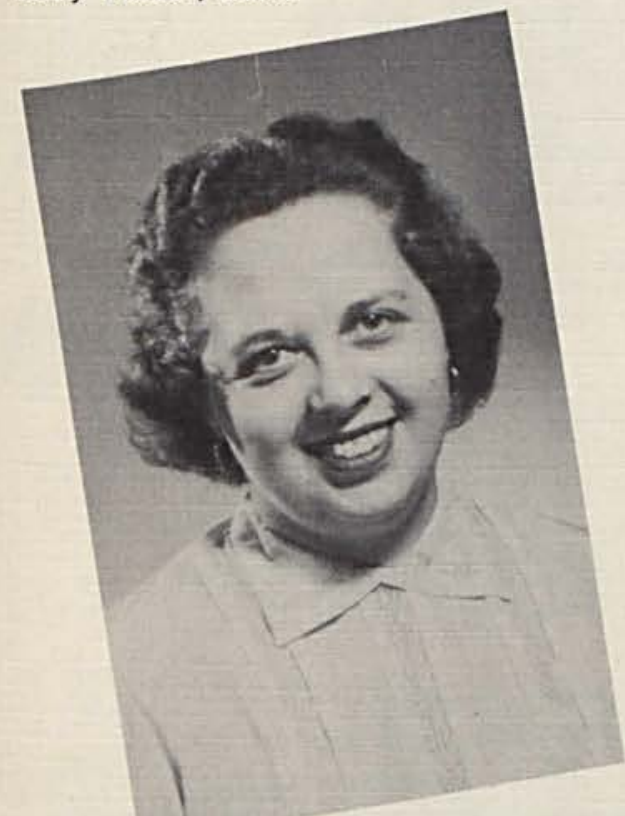

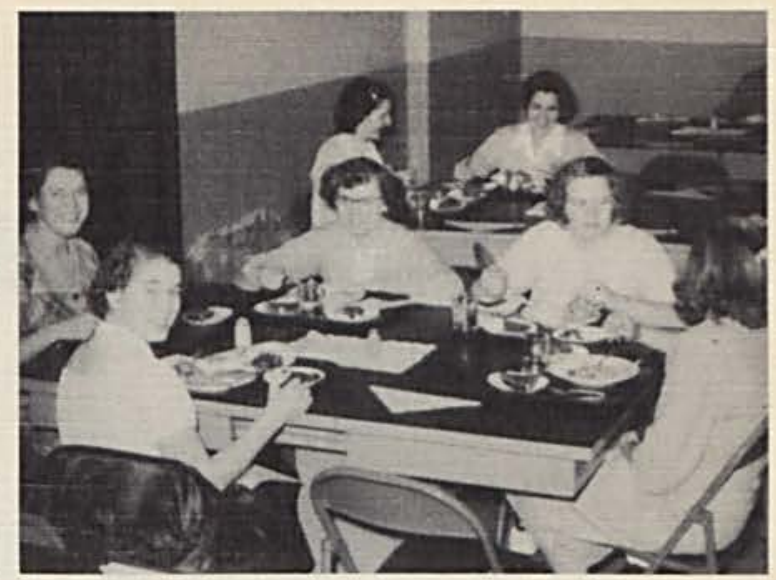

Since the staff got off to a very late start it was almost impossible to meet the deadlines though after prodigious effort by the entire General Science class the last copy was sent in very close to the final due date.

The class feels that they have all learned much about the production of yearbooks and look forward to applying the experience if their teaching position requires the advising of a yearbook staff.

We express our appreciation to Prof. Elwood Shaw for his advice, tireless efforts, and endless hours spent in helping us to complete this yearbook. Also we thank Betty Yeider for her work in arrangement and proofreading of final copy.

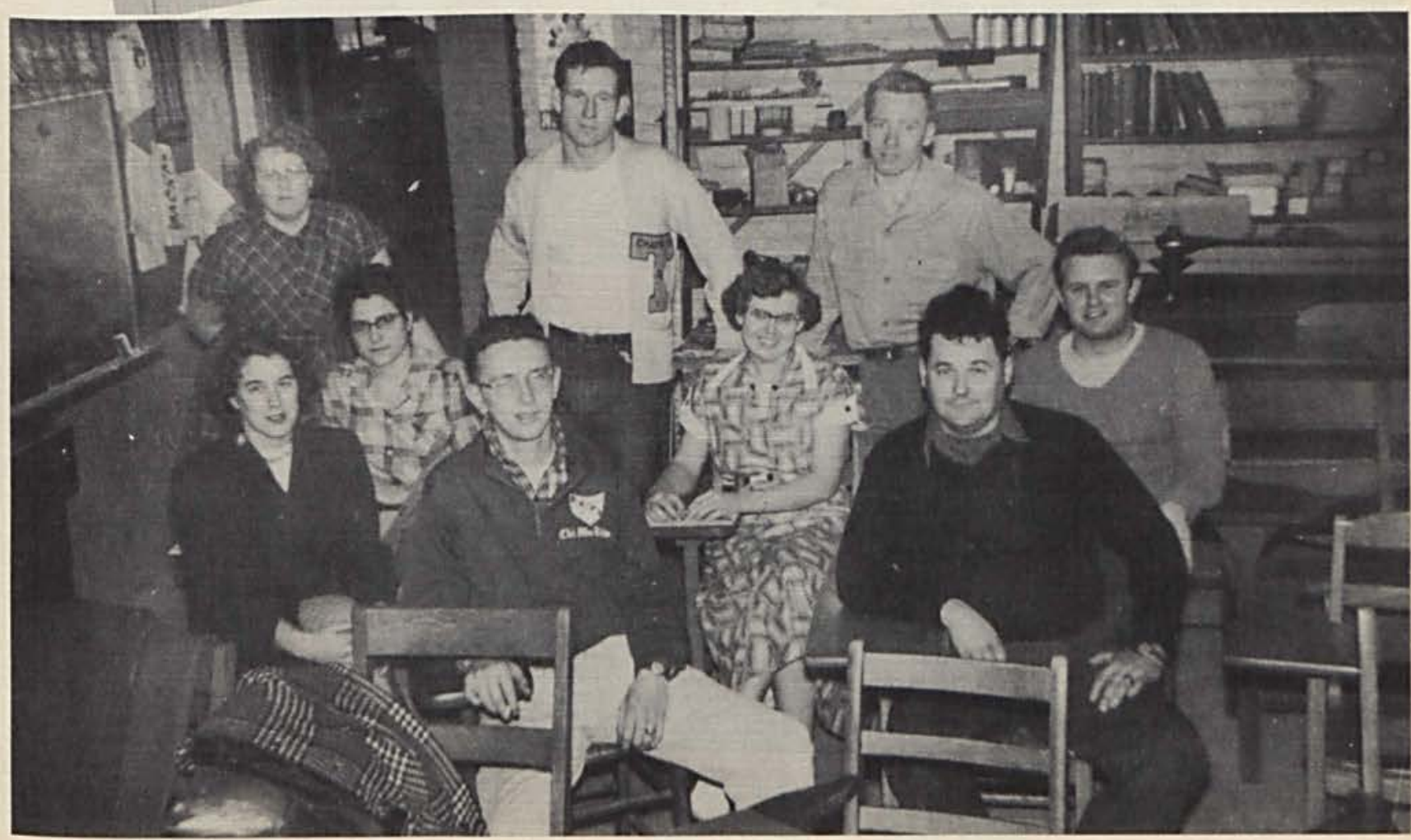




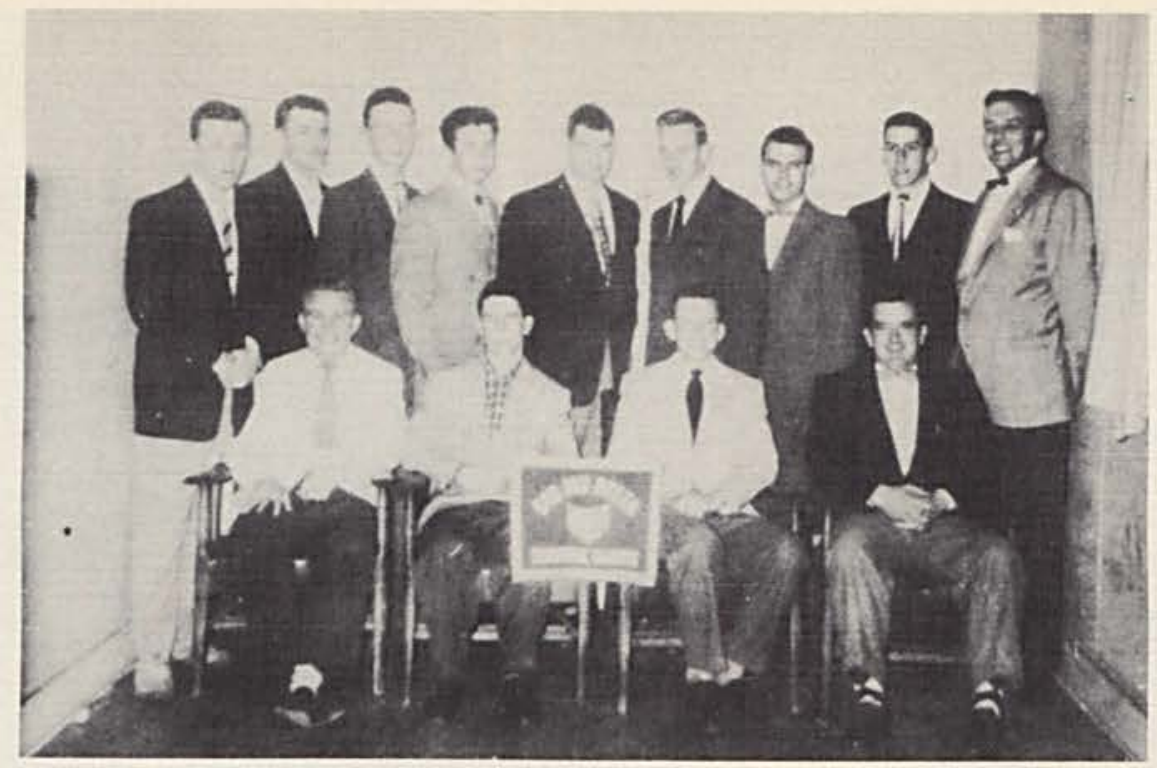

FIRST ROW, LEFT TO RIGHT: Jim Wagner, Dave Wheeler, Advisor Don Edington, Edward Kurs. STANDING: Ken Carpenter, Vernon Francis, Roger Mann, Aubrey Boutin, Dave King, Don Staggs, Richard Syrek, Bill Siebert, Jim Hartman.

The Chi Mu Delta Fraternity, a local organization established in 1941, has completed another successful year on the Cedarville Campus. This fraternity has sponsored many social events on the campus, the most outstanding being the annual spring formal which follows the May Day program.

At the present there are fifteen active members and ten prospective pledges. The officers include James Hartman, President; David King, Vice-president; Roger Mann, Treasurer; Donald Staggs, Secretary; and Vernon Francis, Sergeant at Arms. Donald Edington is the Faculty Advisor.

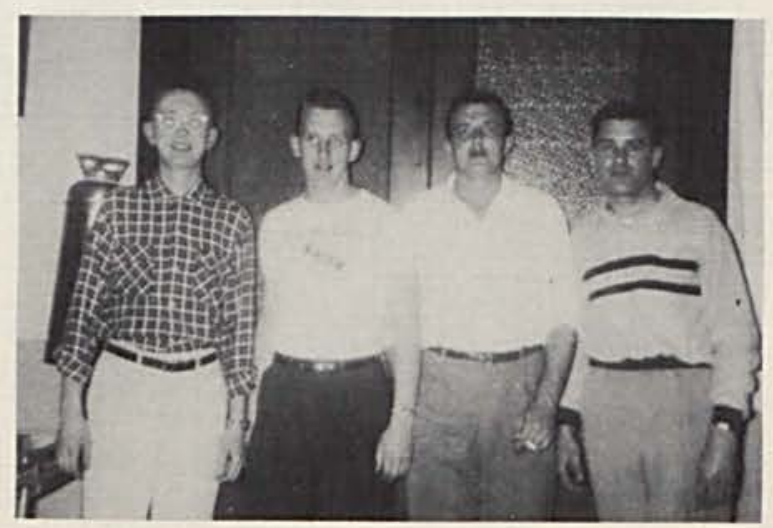

LEFT TO RIGHT: Roger Mann, TREASURER; Donald Staggs, SECRETARY; James Hartman, PRESIDENT; Vernon Francis, Sergeant at Arms. 


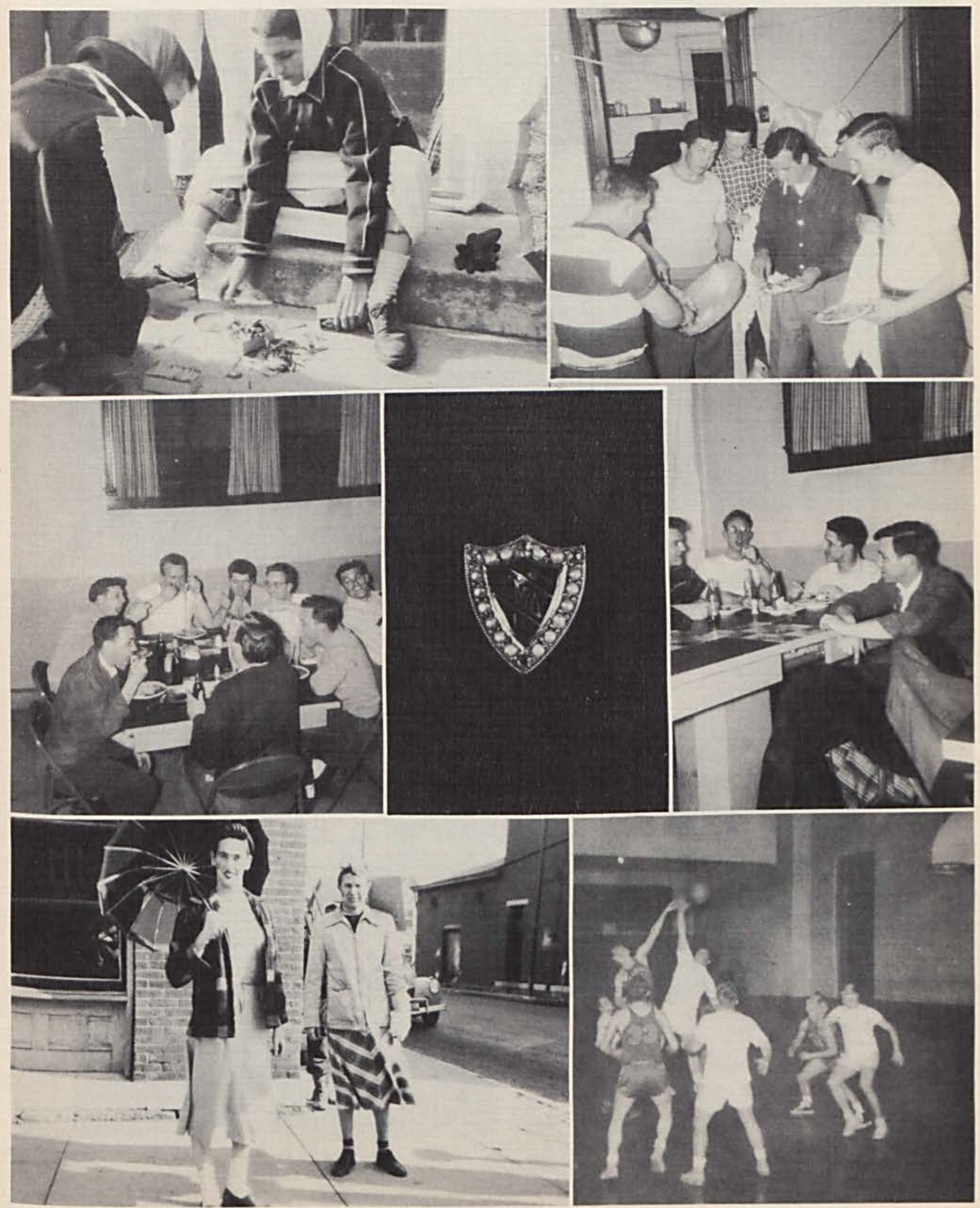




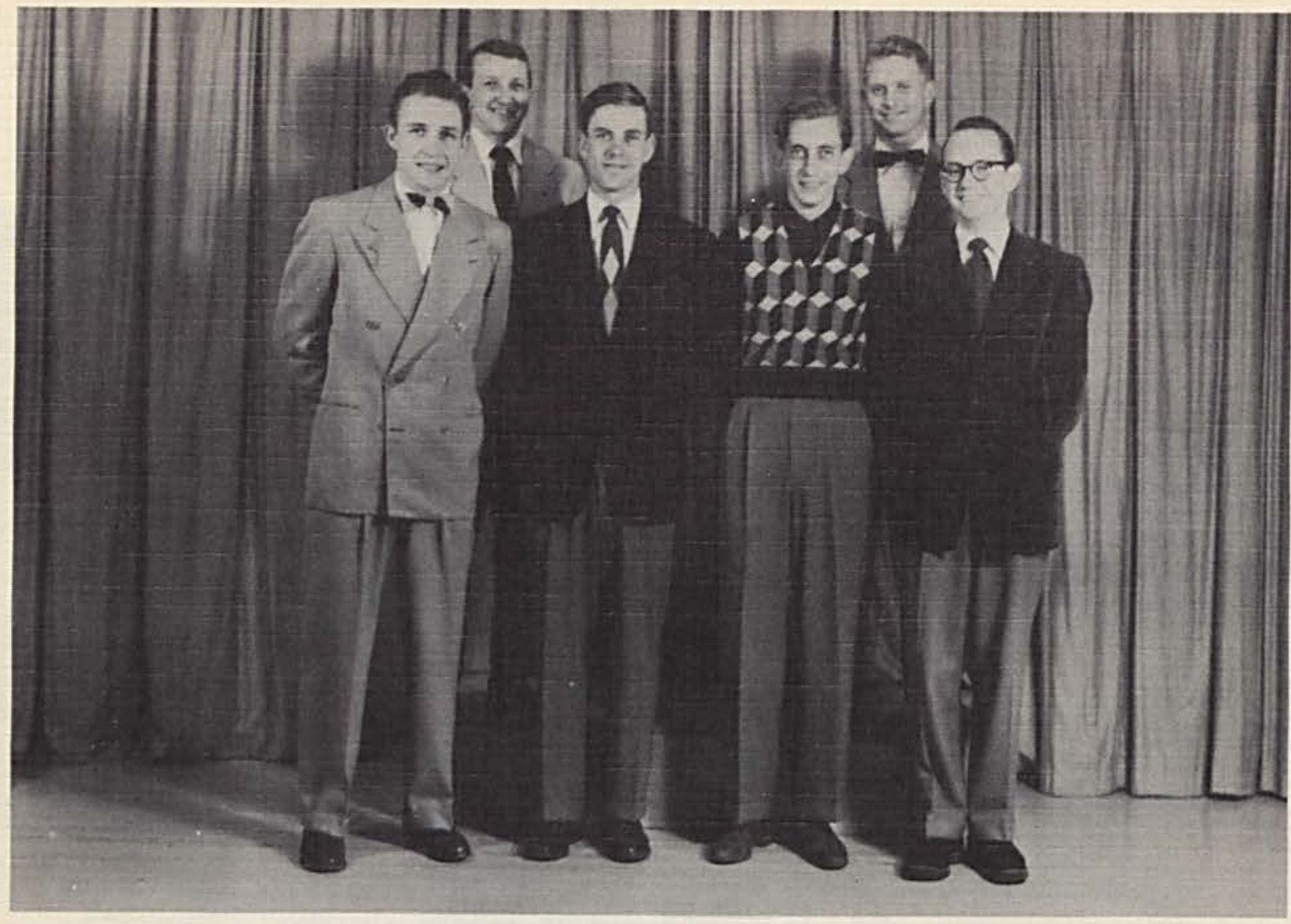

FIRST ROW, LEFT TO RIGHT: Melvin Tackett, Bill Fife, Paul Fiedler, Tom Still. SECOND ROW, LEFT TO RIGHT: Dave Spitzer, Jim Luttrell.

\section{KAPPA SIGMA KAPPA}

OFFICERS

PRESIDENT: James Luttrell VICE-PRESIDENT: Dave Spitzer SECRETARY: Paul Fiedler TREASURER: Charlie Thomas
The Kappa Sigma Kappa fraternity is a national fraternity established at Virginia Military Institute in September, 1867. It is now composed of fifty chapters reaching from British Alpha in London to Tasmania Alpha in Australia. Ohio, West Virginia and Illinois have the most chapters per state.

The local chapter was chartered on this campus in the spring of 1948. Many of the Fraternity members graduated and this cuts it's active membership to a few.

The Fraternity has sponsored a number of dances and social activities through the year. 


\section{K. S. K.}

\section{SNAPS}
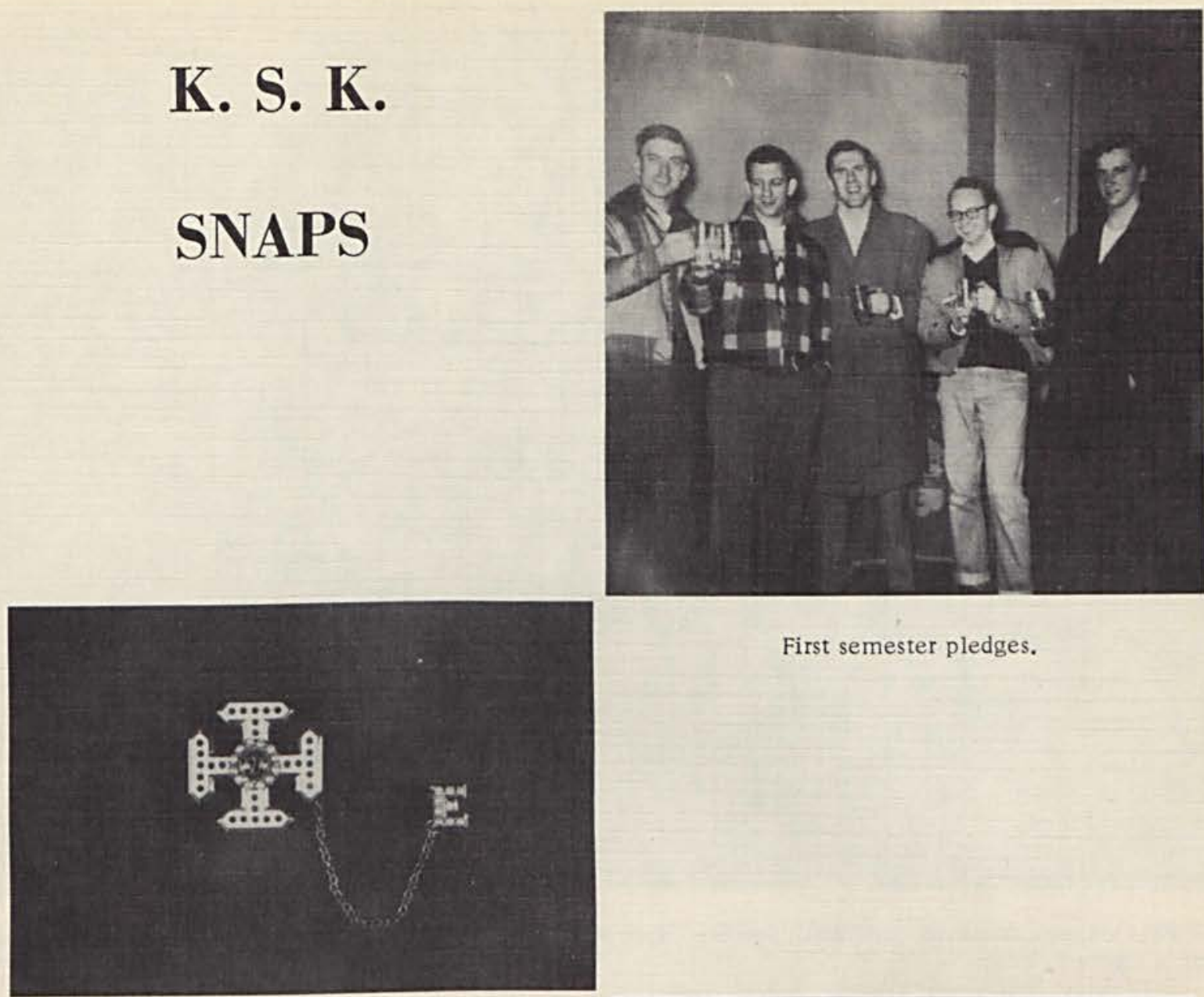

First semester pledges.

Fraternity pin.
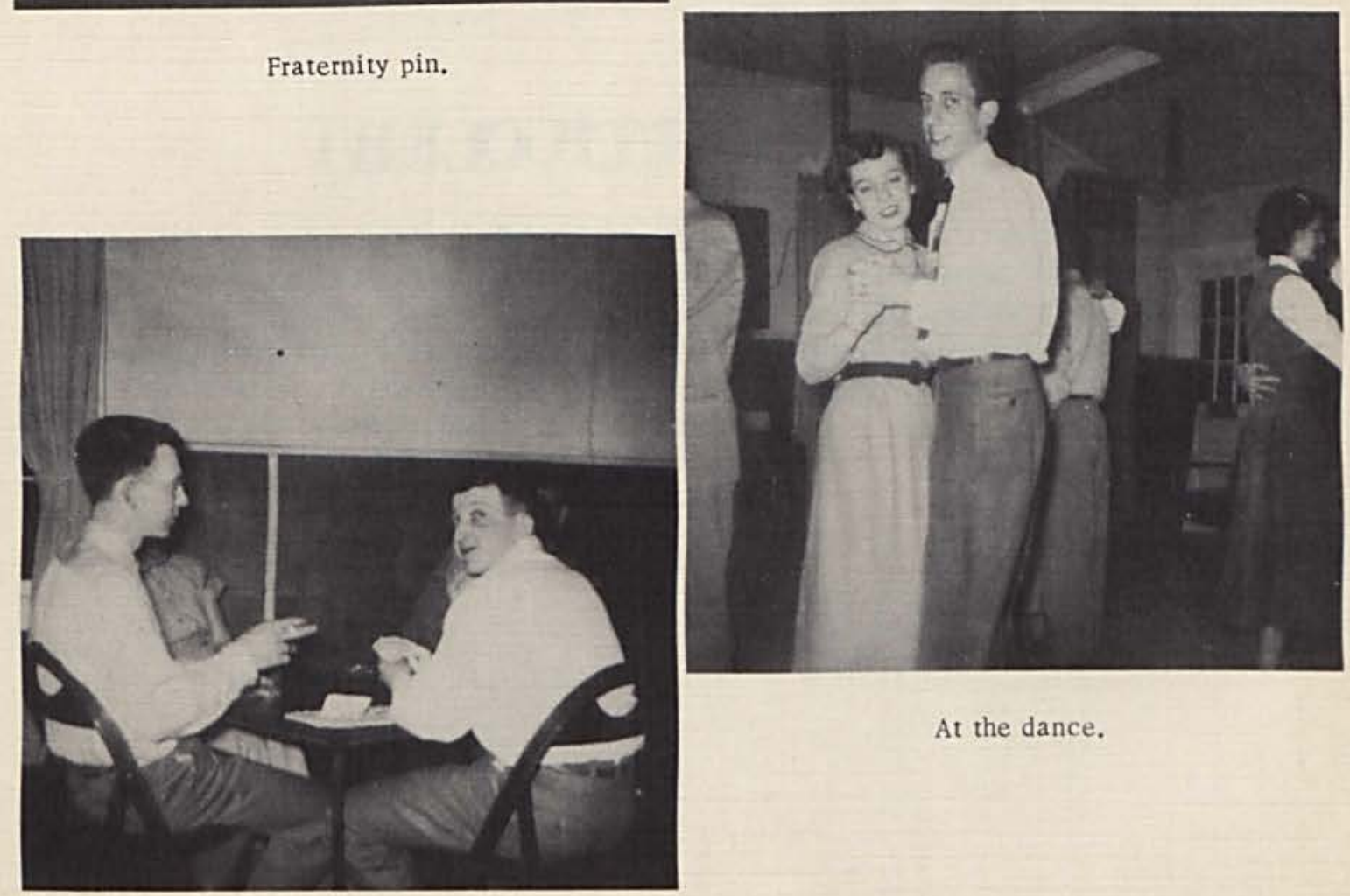

At the dance.

Another tale comming up. 


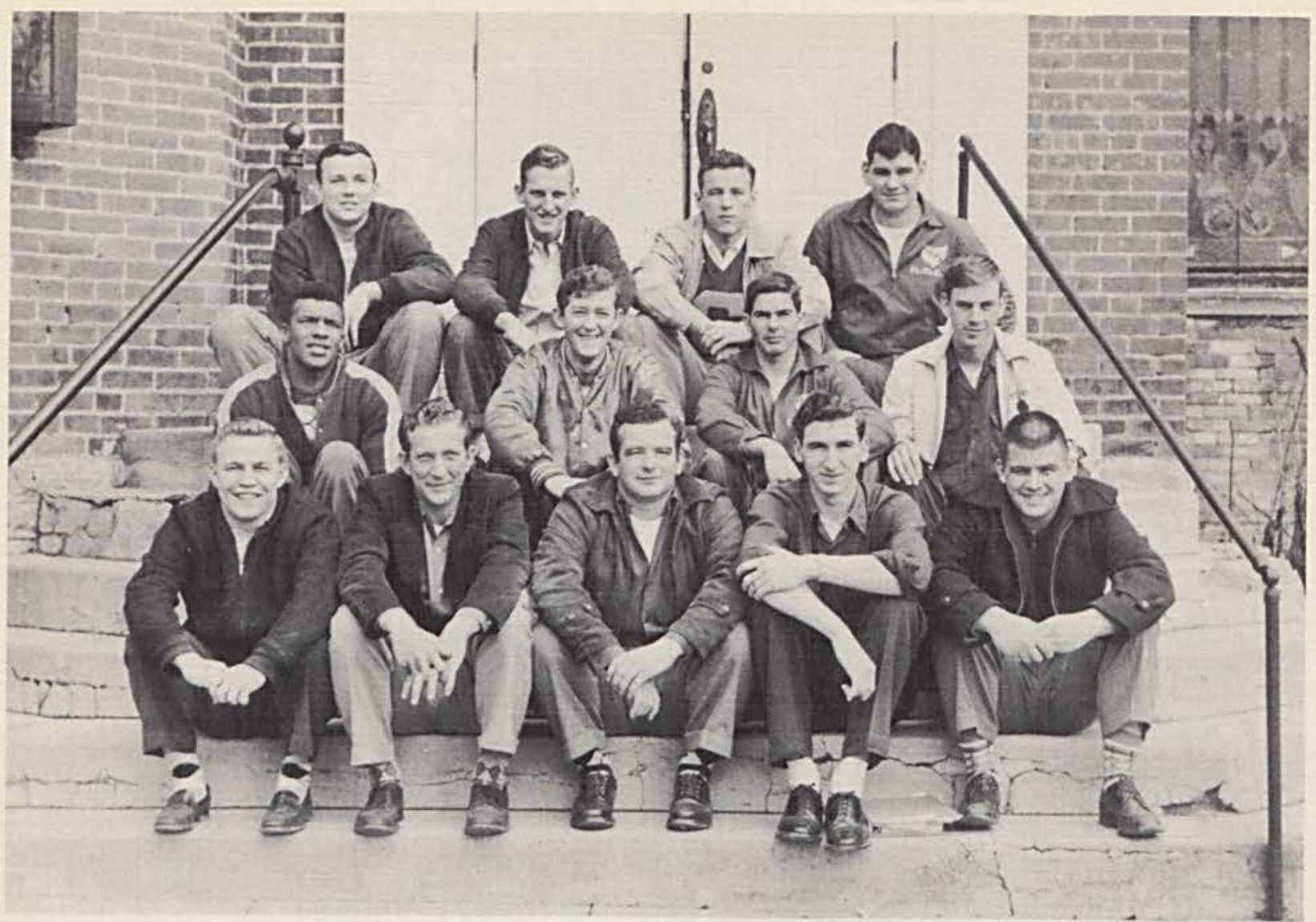

1ST ROW: Wagner, Goodwin, Jurs, Brill, Spichty. 2ND ROW: Burton, Farmer, Downs, Fife. 3RD ROW: Hartman, Staggs, Carpenter, King.

\section{VARSITY "C"CLUB}

The Varsity C Club was reestablished this year at Cedarville College. It is composed of members, who have earned a letter in one or more sports. Kennth Carpenter was elected president. This club has been active through out the year and have sponsored several dances, among these was the Homecoming Dance. 


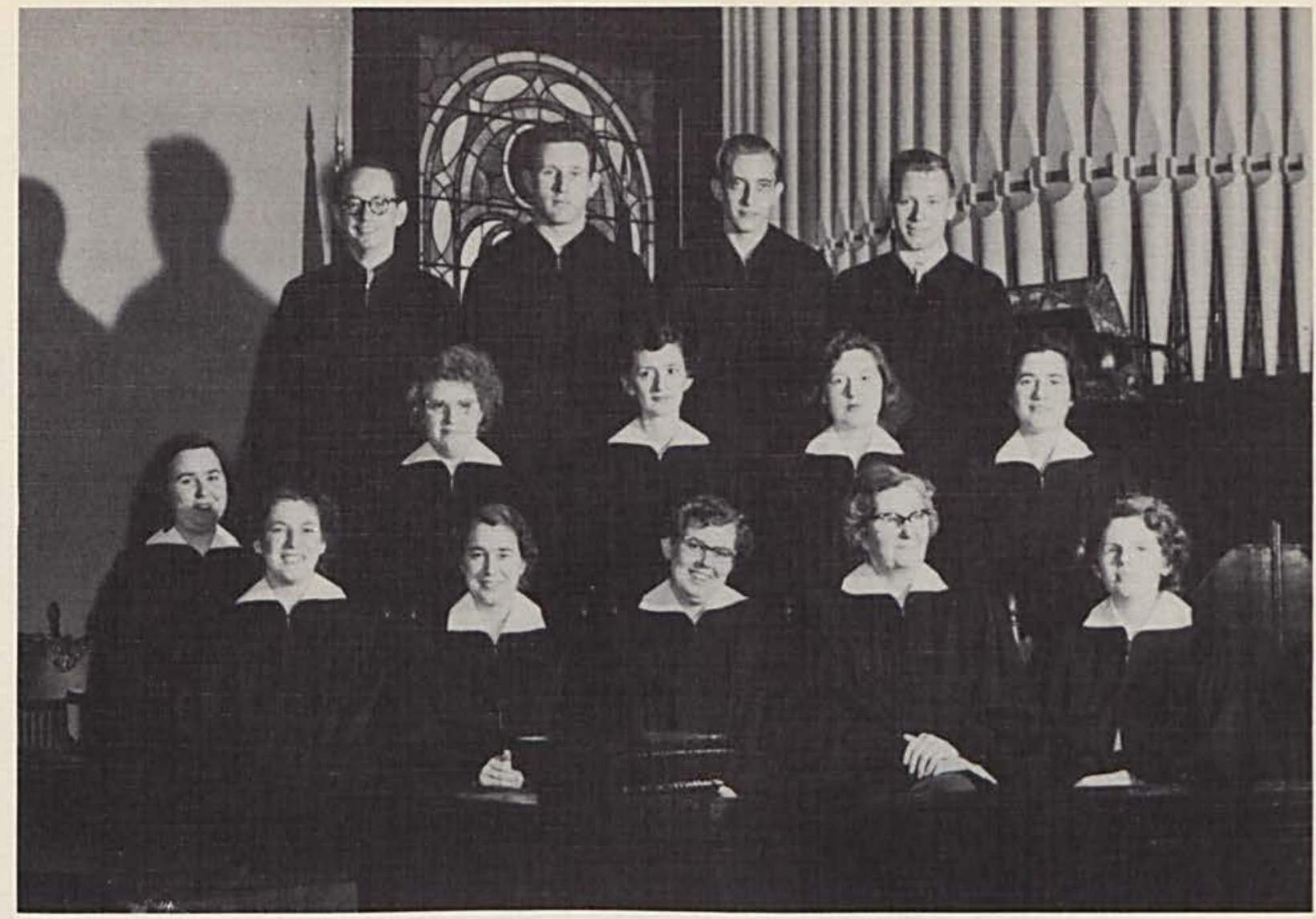

FIRST ROW: Rebecca Creswell, Dorothy Creswell, Martha Lough, Pauline Powers, Mrs. Crumrine. SECOND ROW: Glenna Anderson, Charlotte Shaw, Anne Huffman, Nancy Guilfoyl, Naomi McNeal. THIRD ROW: Tom Still, Wayne Joyce, Paul Fielder, Al Glover.

\section{THE COLLEGE CHOIR}

The College Choir, directed by Naomi McNeal, with Mrs. Crumrine, accompanist, gave several public performances during the year of 1952. It sang at convocation, Lenten Service, and several other off-campus, programs. A splendid group of students enjoyed the activity this year, and those who heard them sing were warm in their praise of the quality of singing. 


\section{STUDENT COUNCIL}

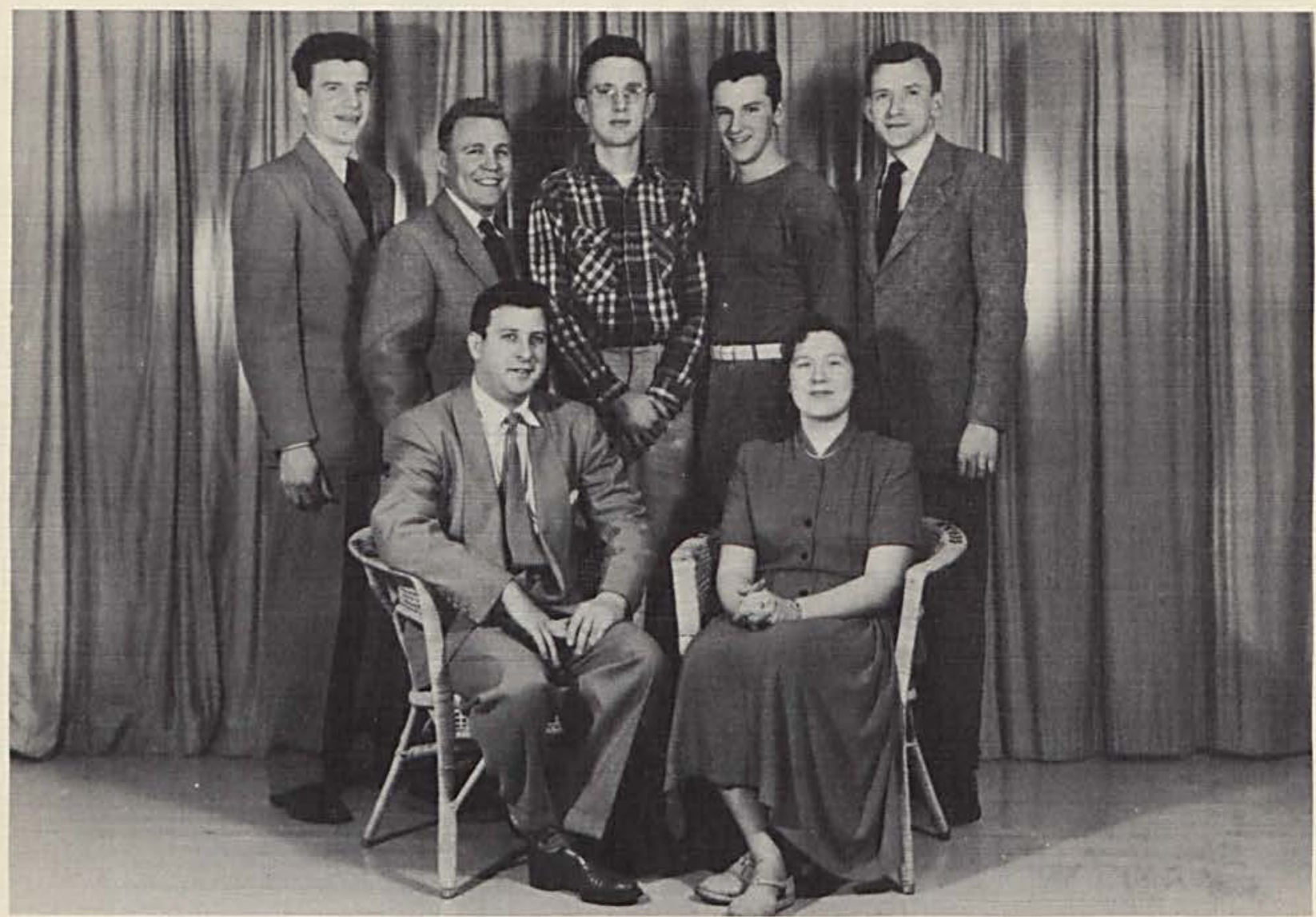

SITTING: John Syrek, President; Nancy Guilfoyle, Secretary. STANDING: Harry Stelling, advisor; Jim Wagner, Roger Mann, Russell Kidd, Donald Edington, advisor.

The Student Council this year has been very active in many ways. It has helped, not only the student body, but the faculty as well, in working out the different problems at hand. Though they were not able to acquire all the things desired, they did accomplish those which were most important. The Student Council is a very strong governing body in our college. 


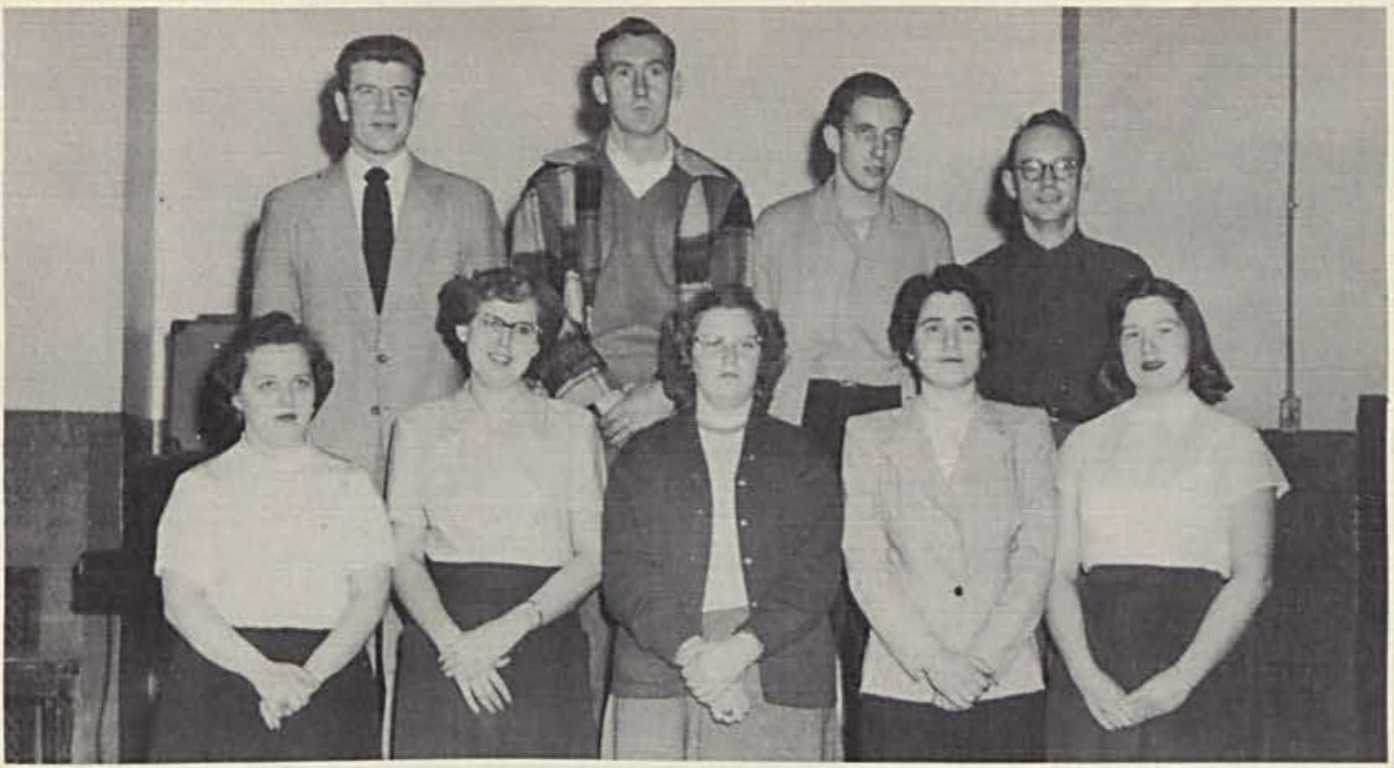

1ST ROW B. Yieder, M. Lough, C. Shaw, N. McNeal, N. Guilfoyl. 2ND ROW - Prof Stelling, D. Evans, P. Fiedler, T. Still.

\section{WHISPERING CEDARS STAFF}

The "Whispering Cedars" is Cedarville College's newspaper. It is published every week in the interest of the college students, the alumni and friends. Since the first publication of the paper four years ago, the aim has been to keep the readers informed concerning news and events on the campus. The paper is published on the third floor of "Old Main" where, each week, you will find a steady scurry to meet the deadline and place the paper at the reader's disposal on Friday.

We express our appreciation to our former editor, Paul Dunn, who spent much time and effort to make the "Whispering Cedars" a success.

Professor Harry Stelling has proven a competent, sincere, sympathetic and energetic advisor. We sincerely thank him for his suggestions and many hours of service in the publishing of the "Whispering Cedars".

Editor: Tom Still

\section{Staff}

Associate Editors: Betty Yieder, Dave Spitzer

Advisor: Professor Harry Stelling

Reporters: Naomi McNeal, Nancy Guilfoyle, Gerald Pitstick, Martha

Lough, Charlotte Shaw, Jim Bounds, Pauline Powers

Business Managers: Jim Luttrell, John Syrek

Sports Editors: David Wheeler, Bill Siebert, Dick Evans

Distribution: Martha Lough, Charlotte Shaw 


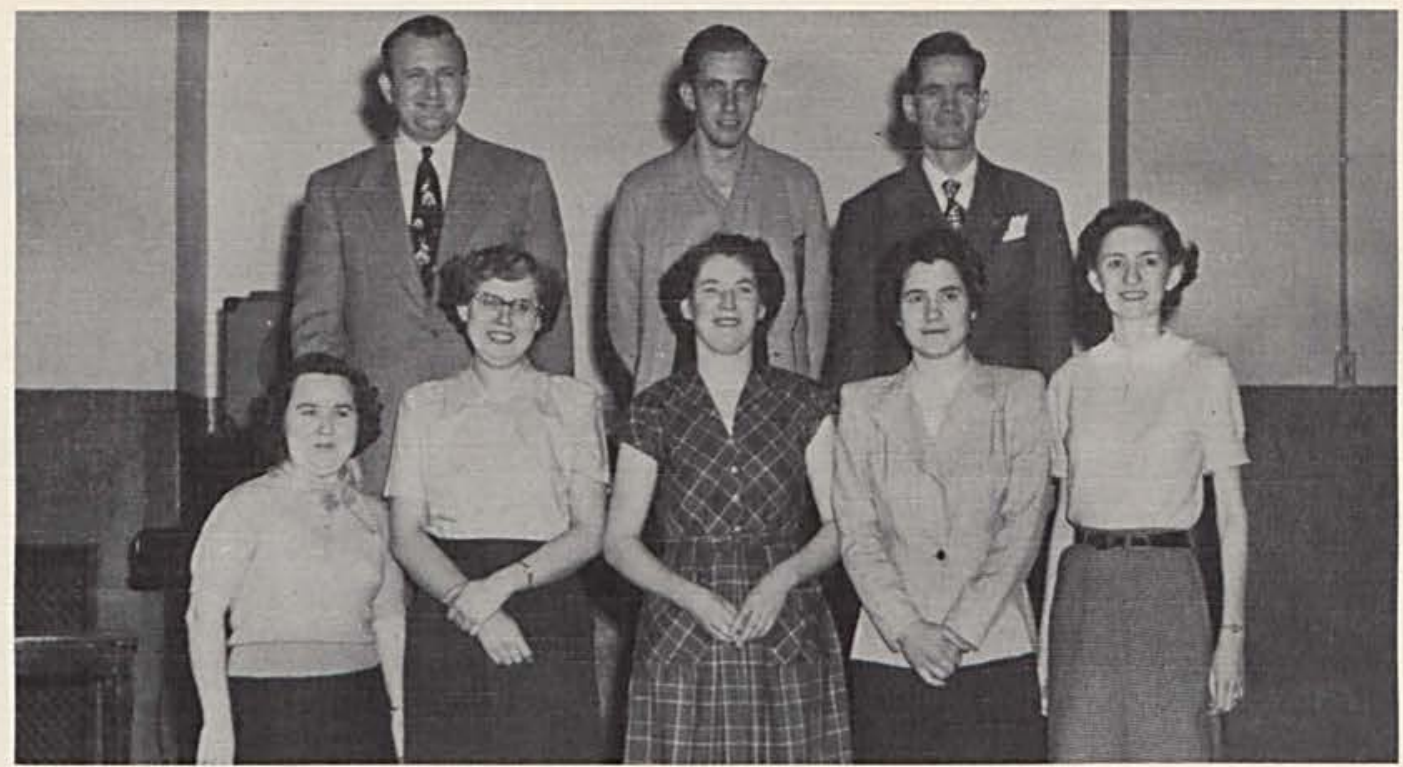

1ST ROW - G. Anderson, M. Lough, R. Cresswell, N. McNeal, A. Huffman. 2ND ROW - Prof. Jansen,P. Fiedler, J. English. ABSENT FROM PICTURE - D. Cresswell, W. Joyce, A. Glover, P. Powers, J. Hulshult.

\section{STUDENT CHRISTIAN ASSOCIATION}

The Student Christian Association was formed by the combination of the YMCA and the YWCA. This first year has been one of organization with Paul Fiedler as president, Rebecca Cresswell as vice president representing the girls, Wayne Joyce as vice president representing the boys, Dorothy Cresswell as secretary-treasurer, and with Prof. Jansen as the faculty adviser.

The purpose of the SCA is to give every young man and woman at Cedarville College an opportunity for fellowship and service. Group discussions to deal with the problems of college students and religion were scheduled. At one meeting Prof. Ramsey gave a talk on "Science and Religion". The group also sponsored a Hallowe'en party and served refreshments after bonfire pep rallies.

In the last semester a "Convocation Committee" composed of Pauline Powers, Chairman, Naomi McNeal, Al Glover, and Jake Hulshult was appointed from the SCA to sponsor the convocations for the rest of the year. 


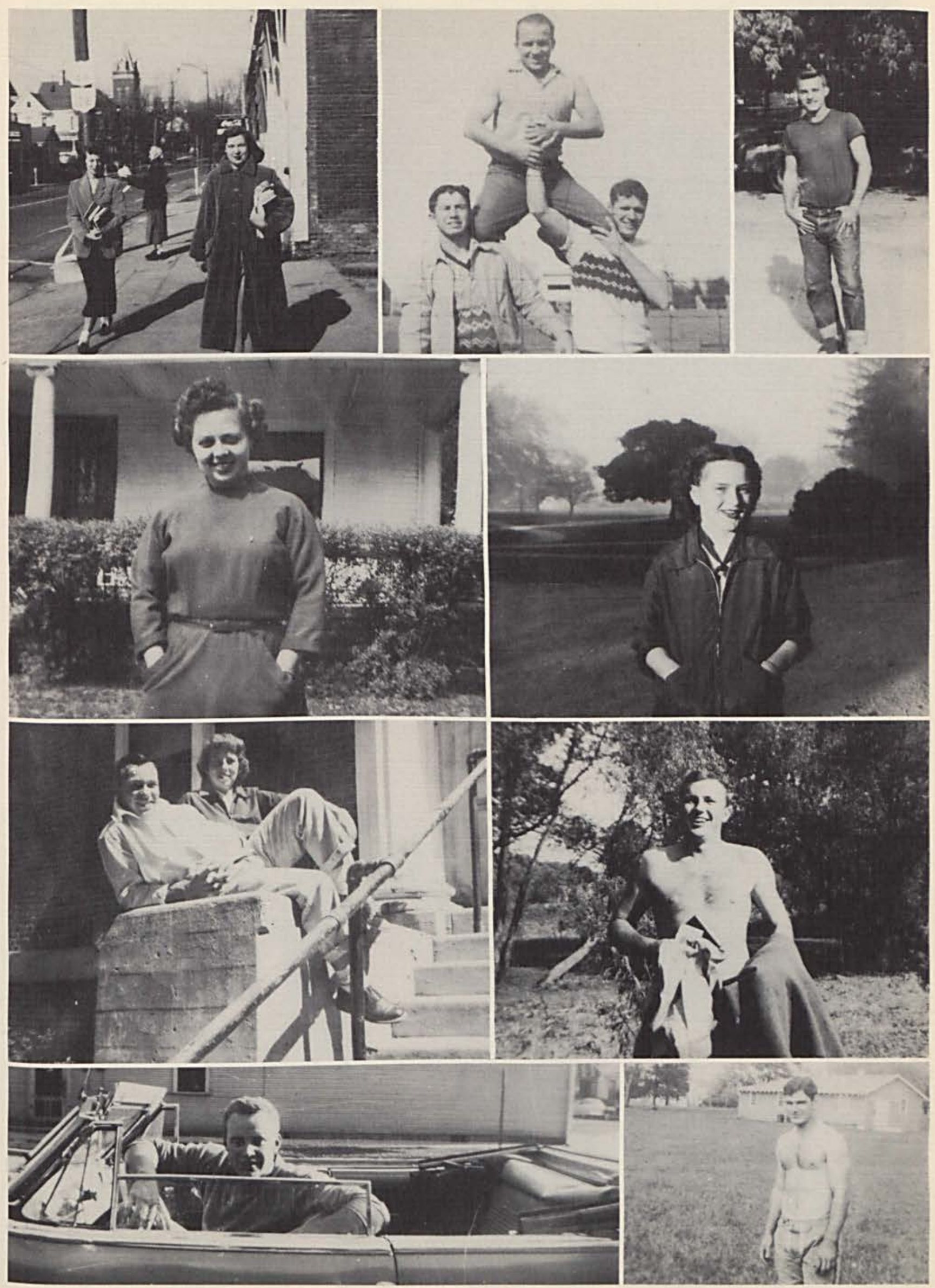




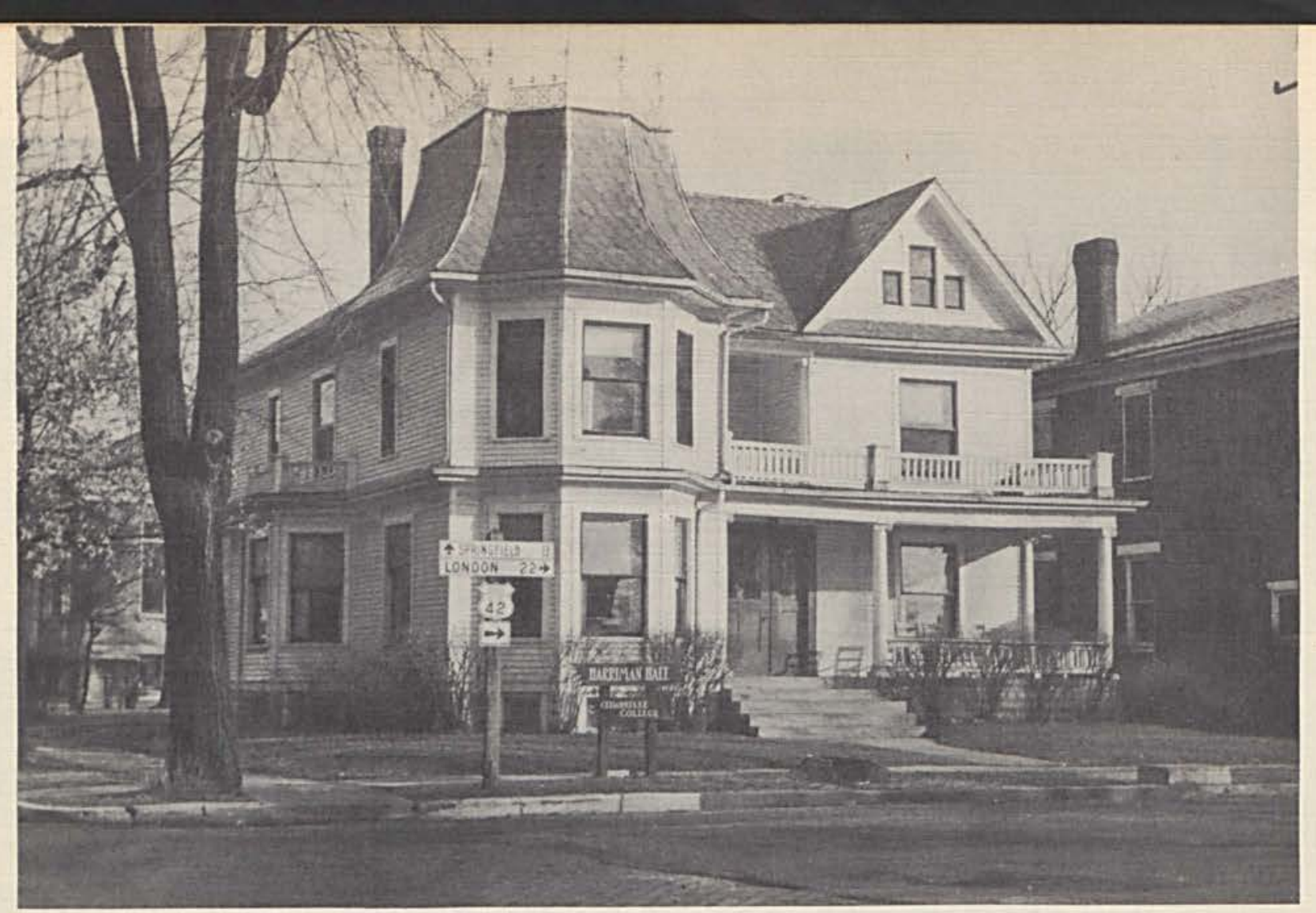

\section{HARRIMAN HALL}
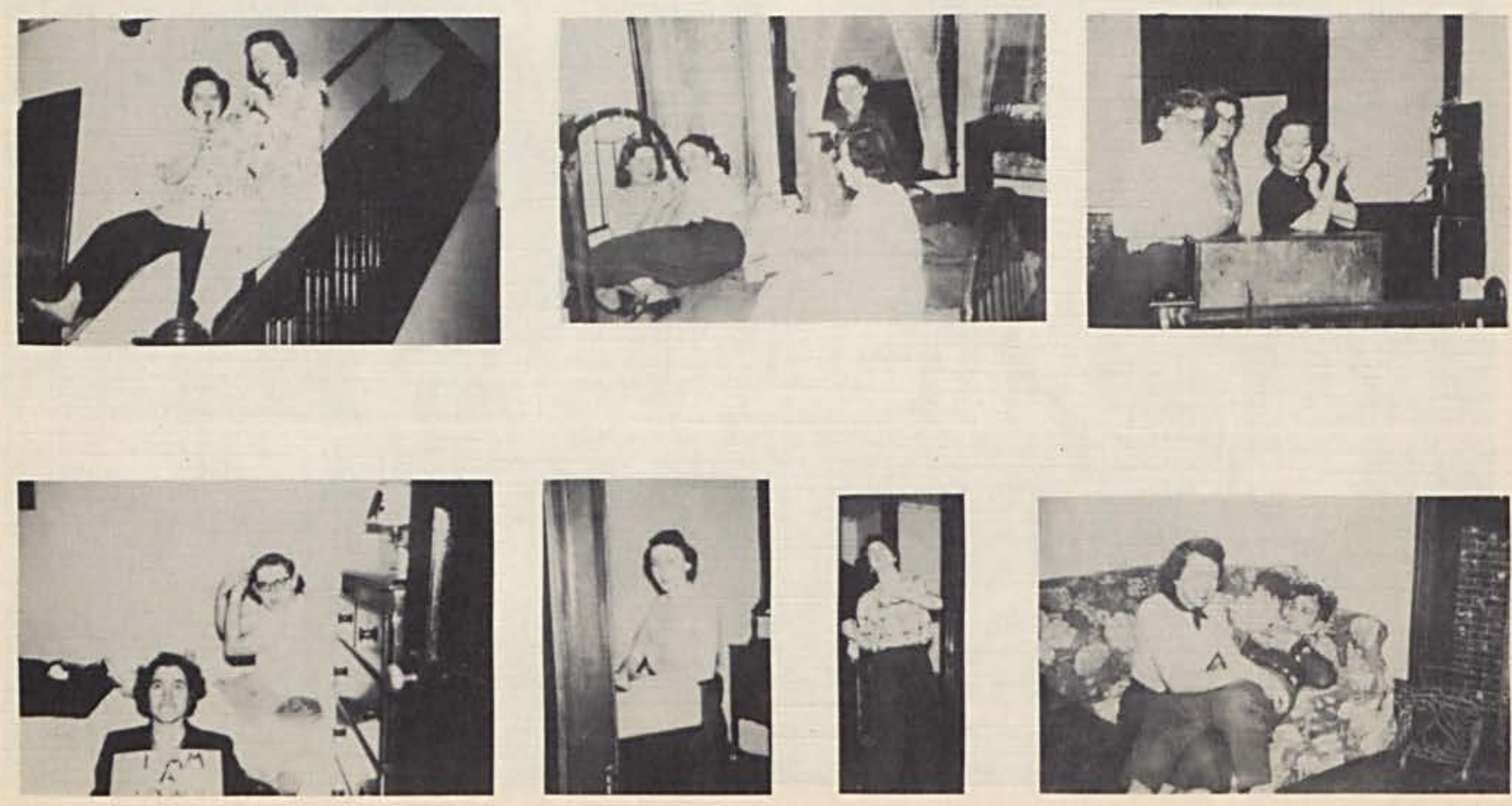


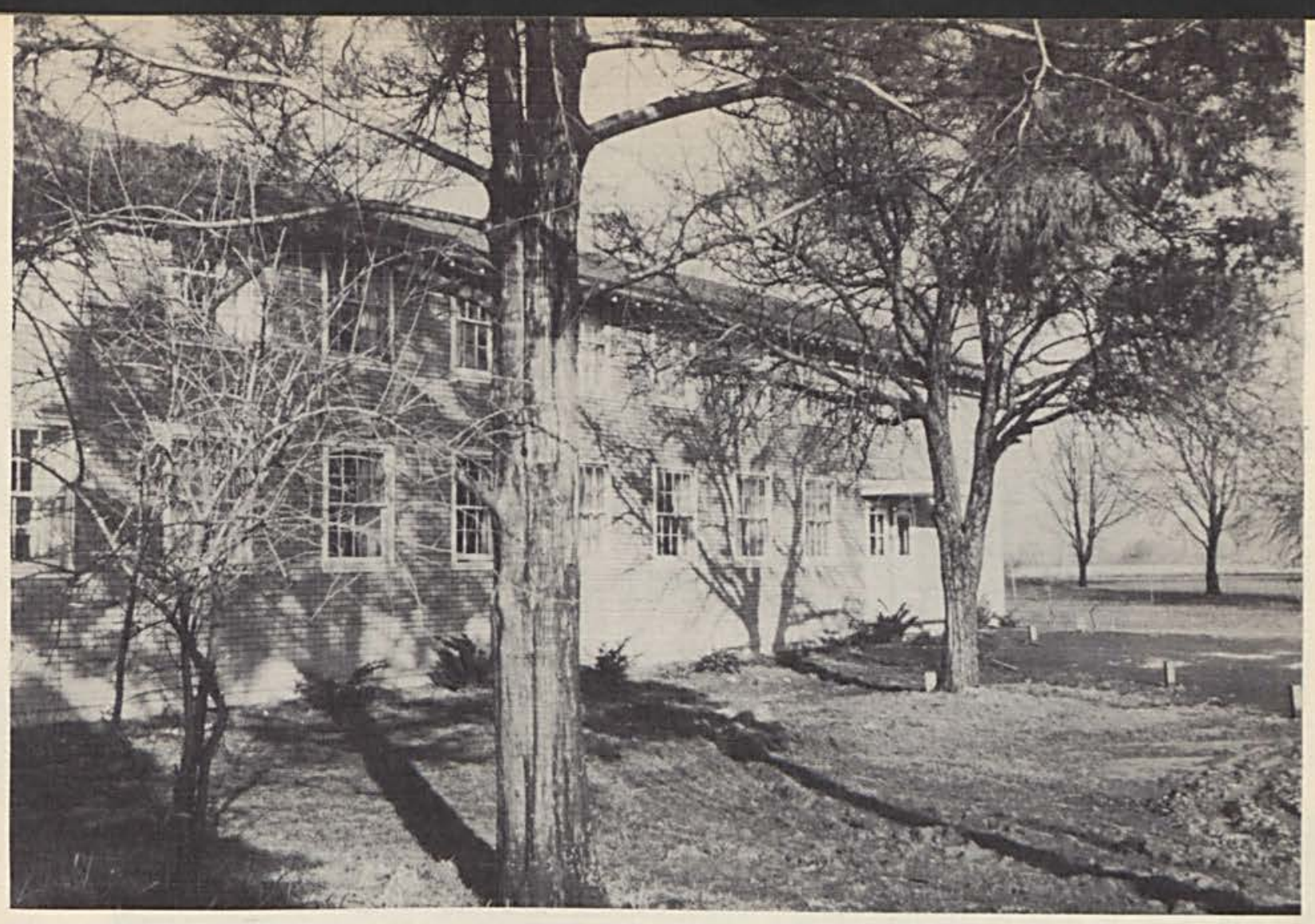

\section{BOY'S DORM Barracks}
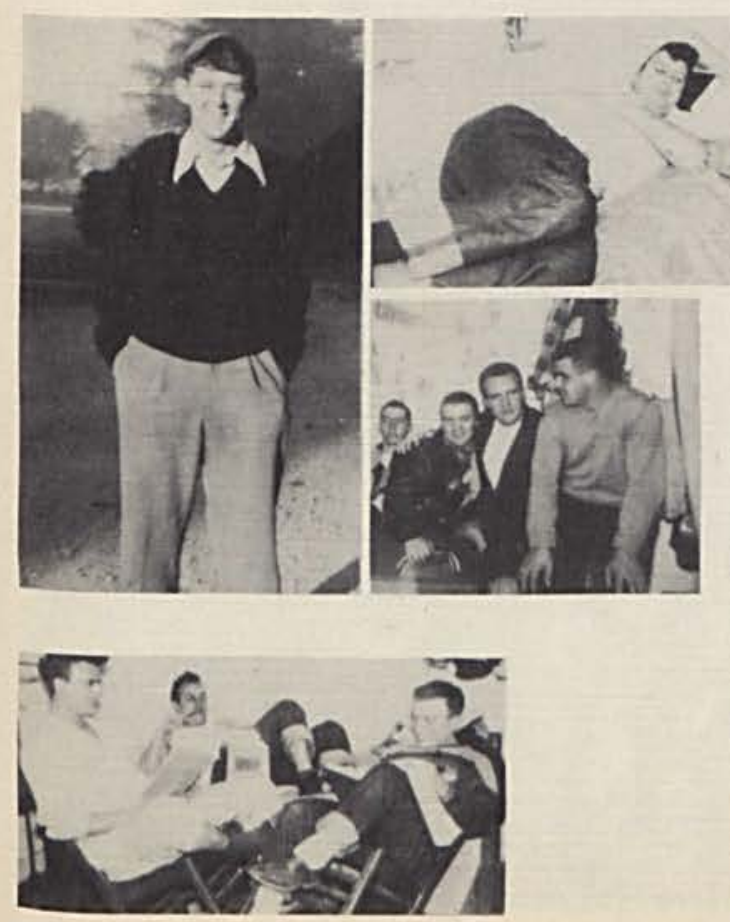
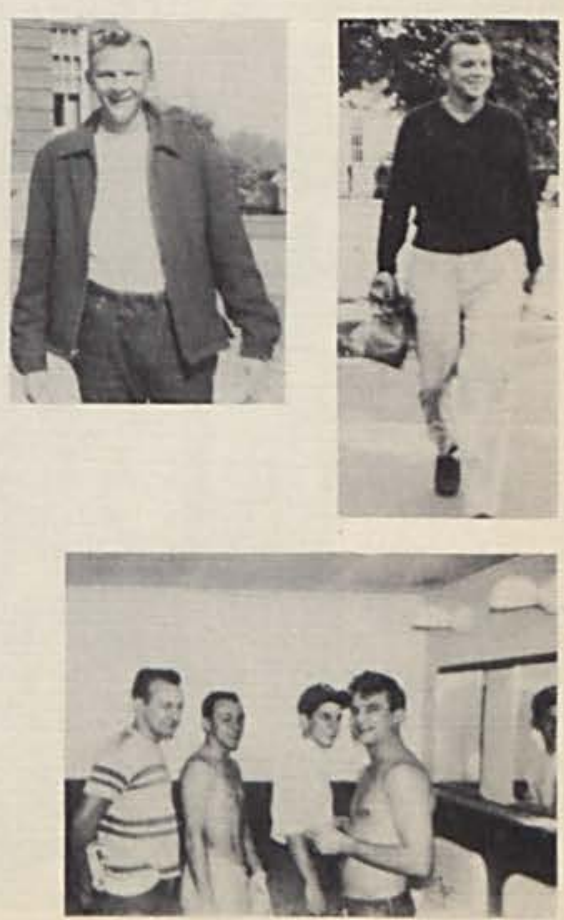

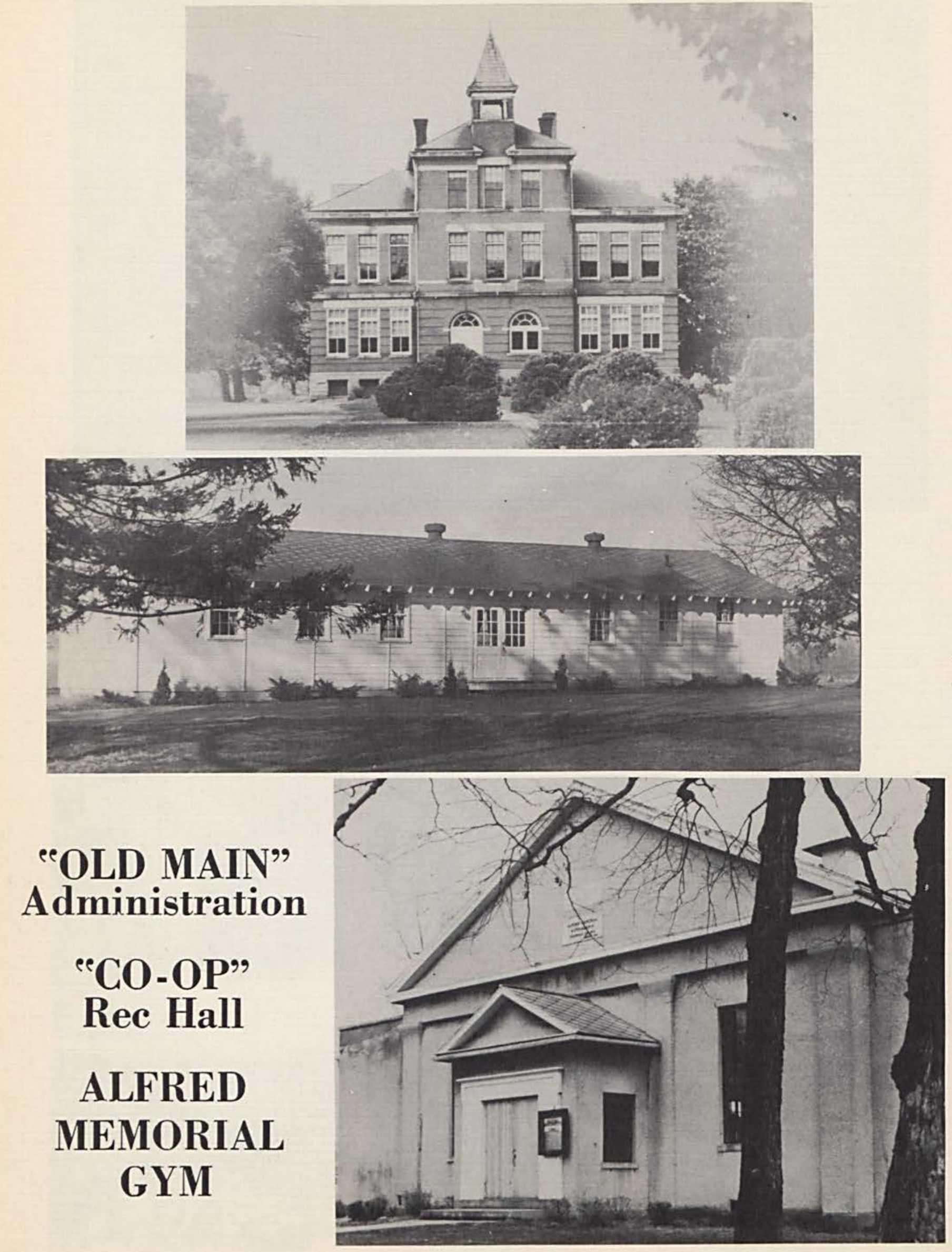


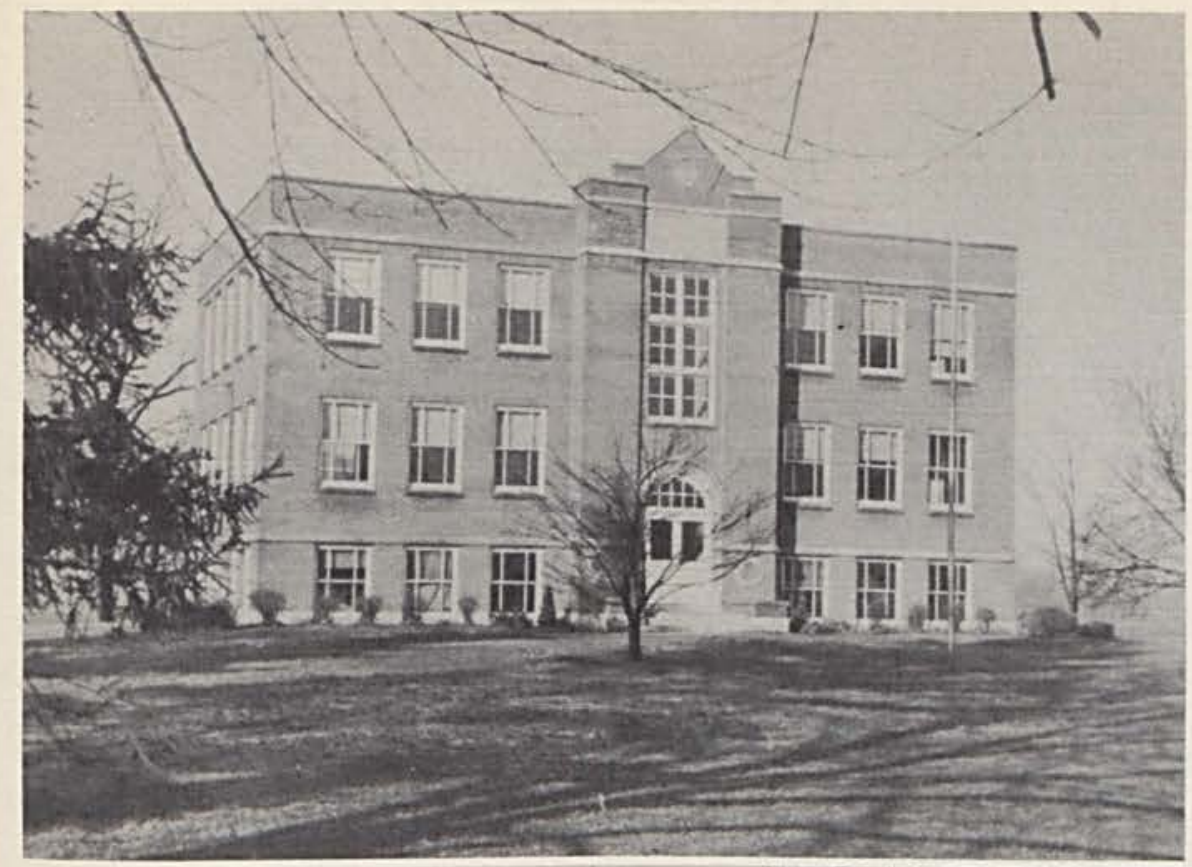

\author{
PHYSICAL \\ SCIENCE \\ BUILDING \\ BIOLOGICAL \\ SCIENCE \\ BUILDING \\ RIFE HALL
APARTMENTS
}
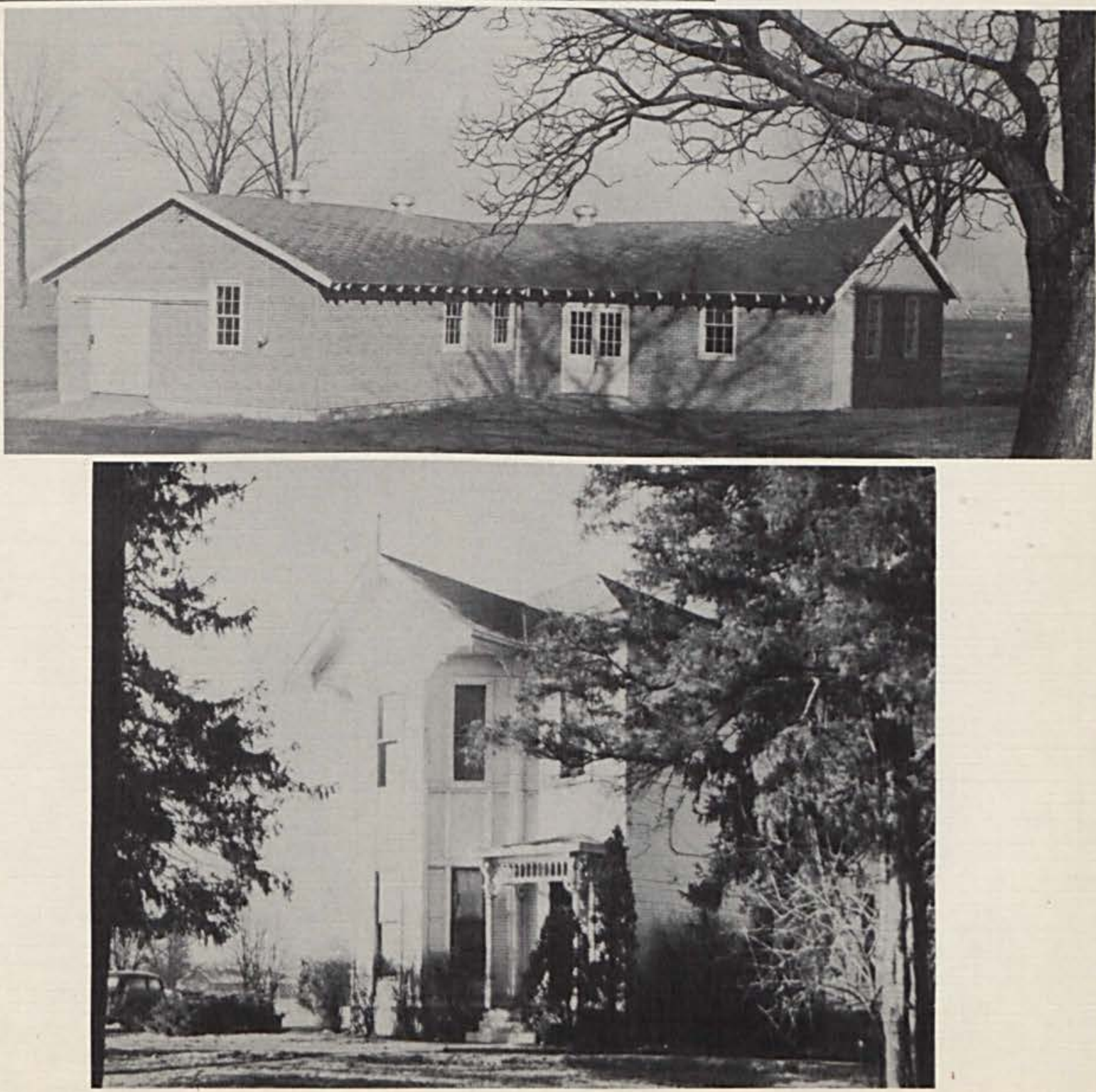


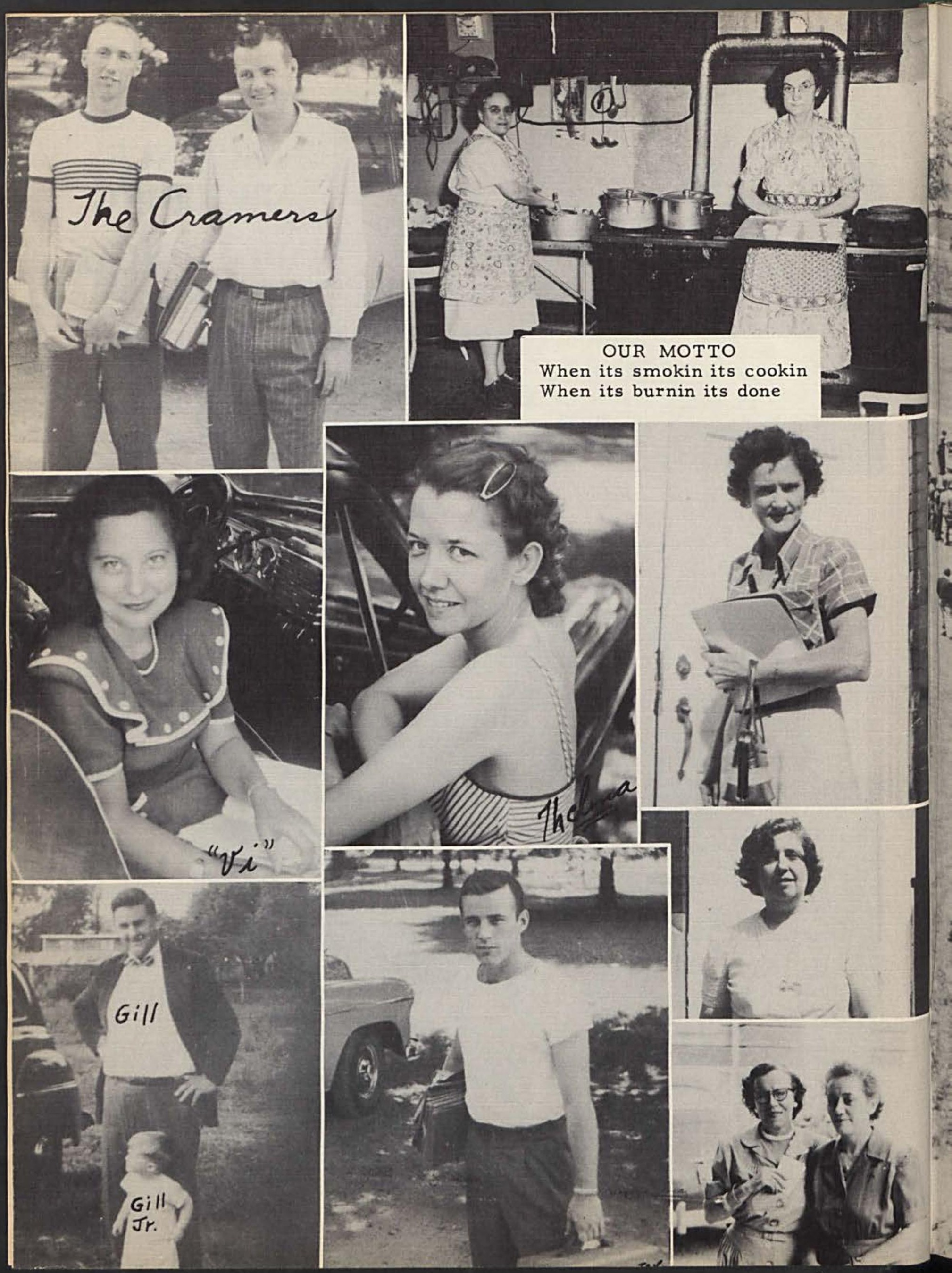




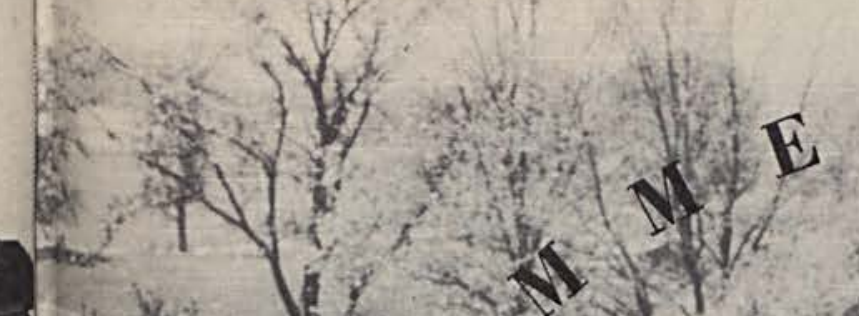

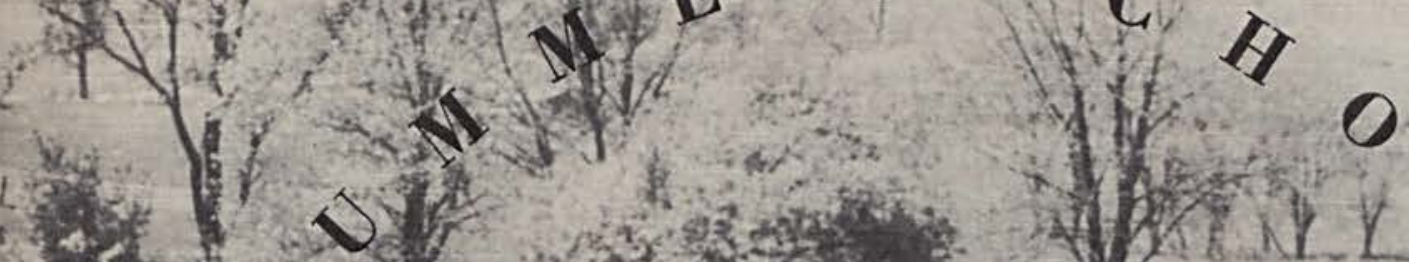
1.5. -

bissis
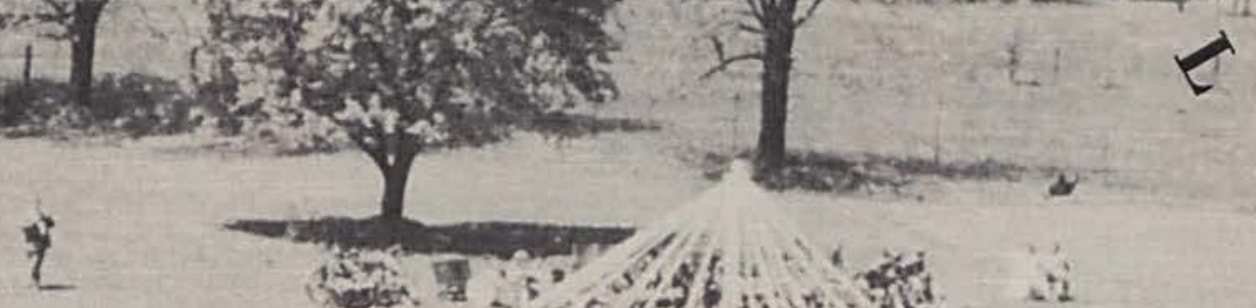

8

II I I

i

650 2) If

Hitising

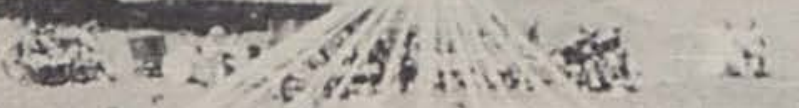

$$
1-1-1-1
$$

2.

3. 3 is

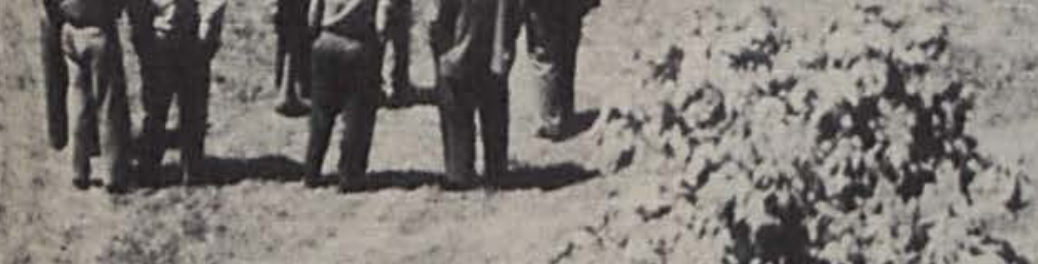

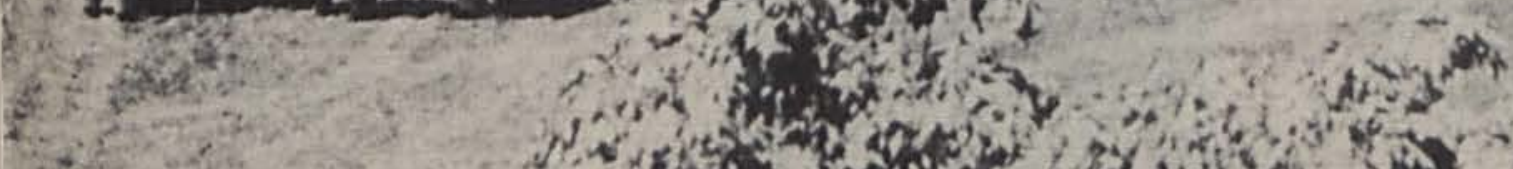

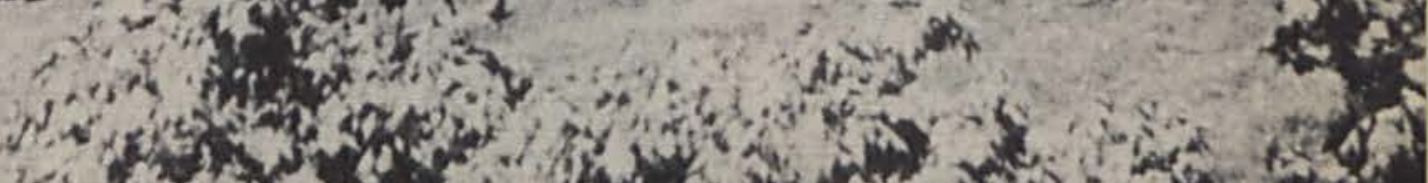

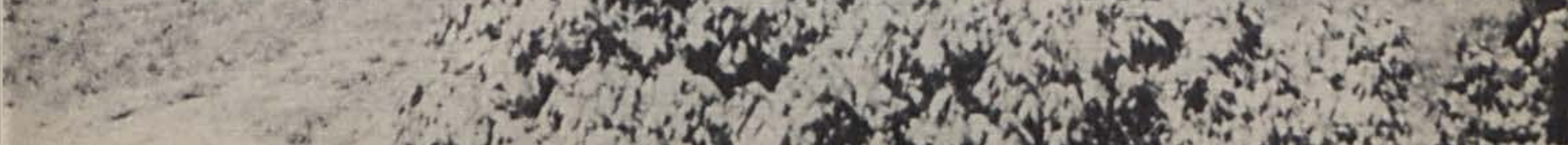

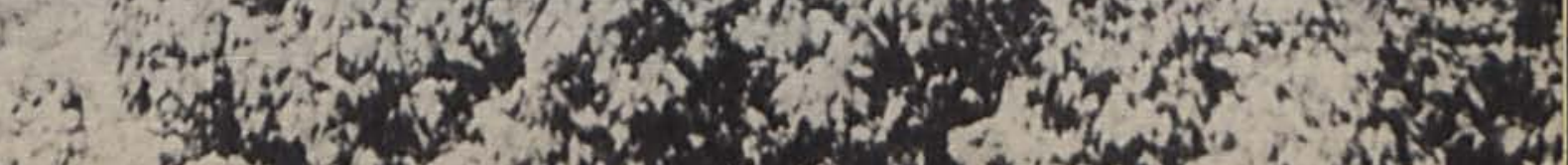

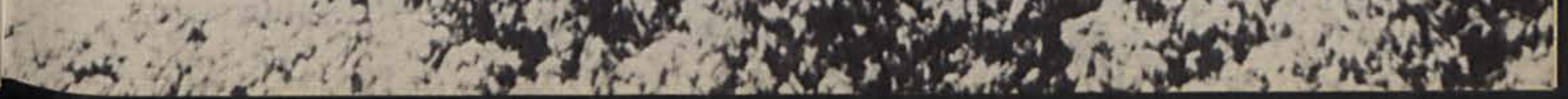



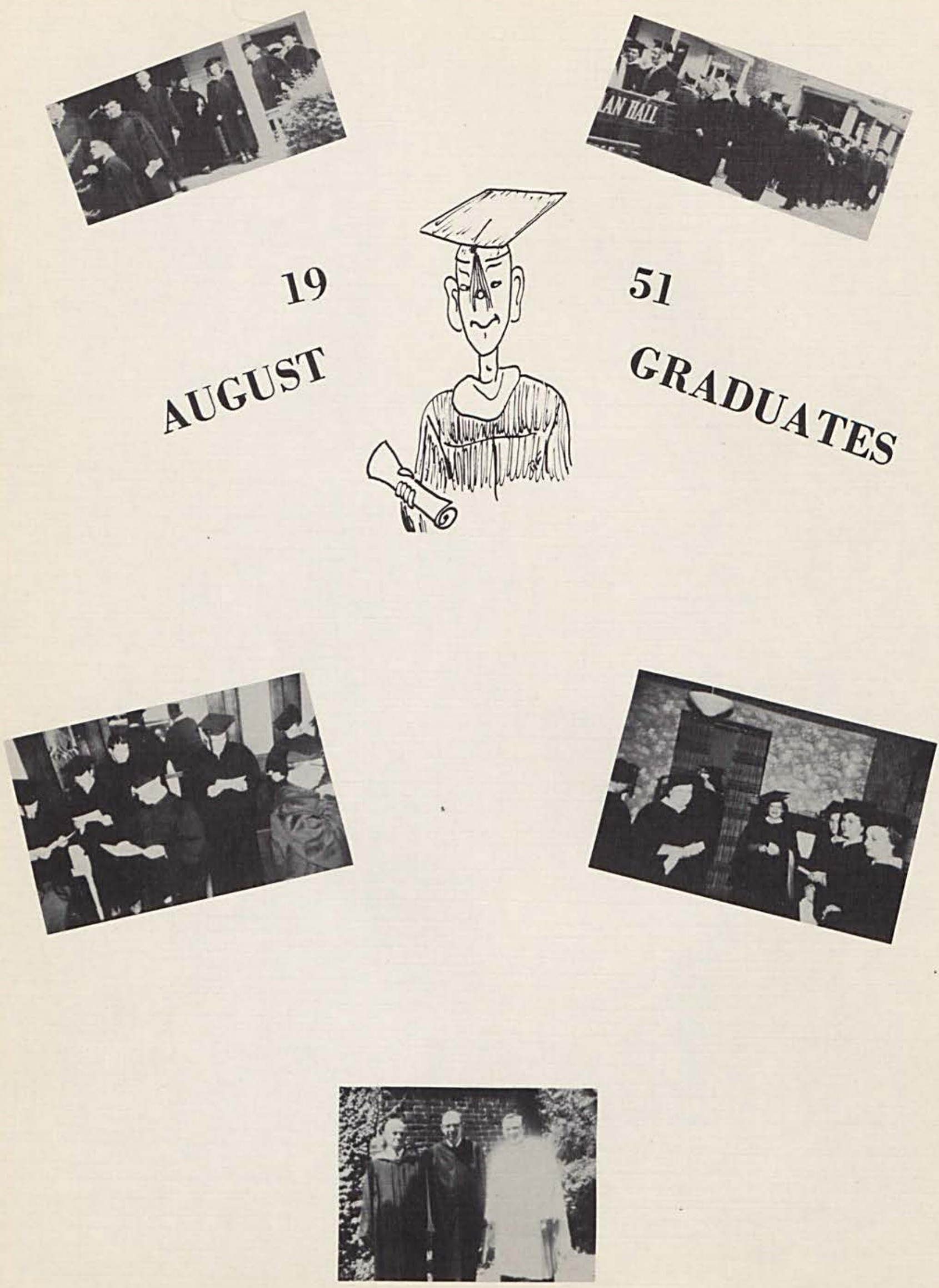


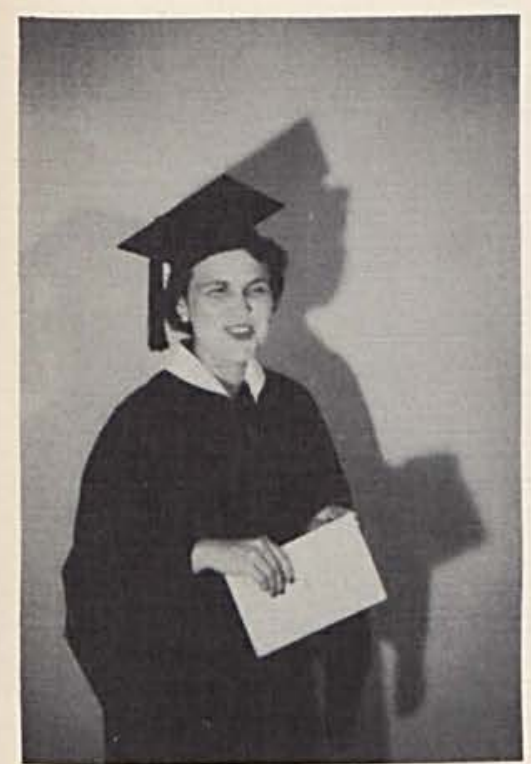

FLORENCE BARKALOW

Xenia, Ohio

B. S. in Education Teaches at Xenia, $\mathrm{O}$.

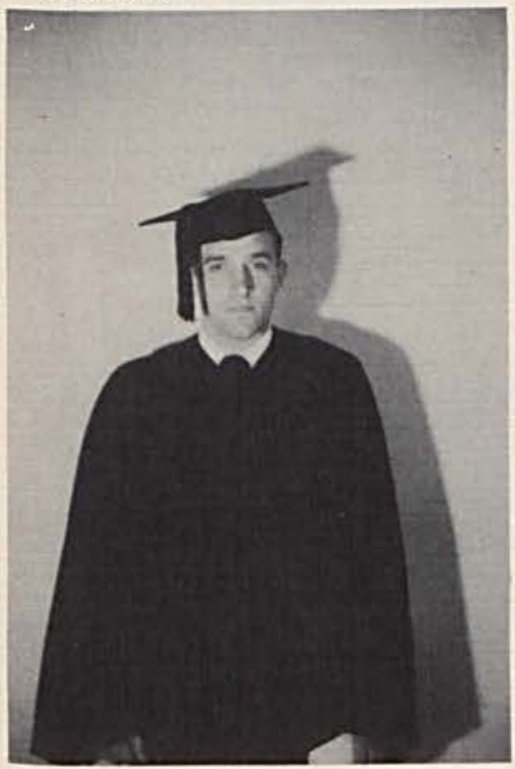

GENE CULTICE

Troy, Ohio

B. S. in Education Teaches at Englewood, $\mathrm{O}$.

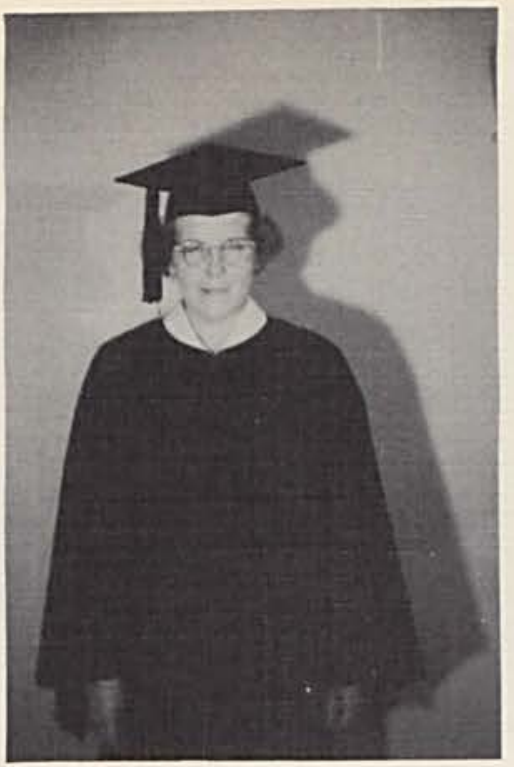

Cedarville, Ohio

B. S. in Education Teaches at Clifton, $\mathrm{O}$.
JOANNA BRYANT

RAY CARTER

Gallia, Ohio

B. S. in Education Teaches at Coalton, $\mathrm{O}$.

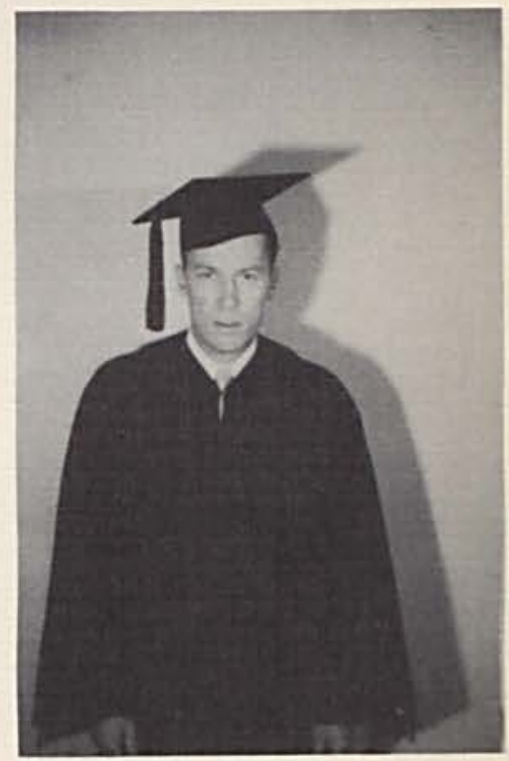

WENDELL CULTICE

Cedarville, $\mathrm{O}$.

B. S. in Education Teaches at Beatty, 0 .

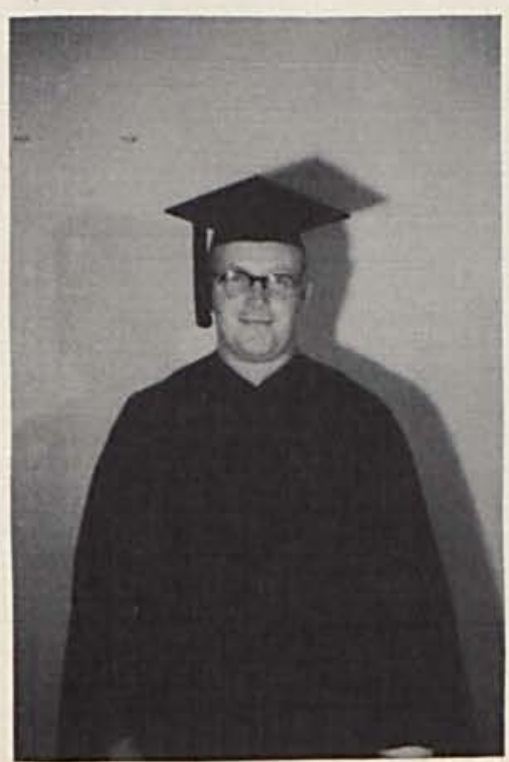

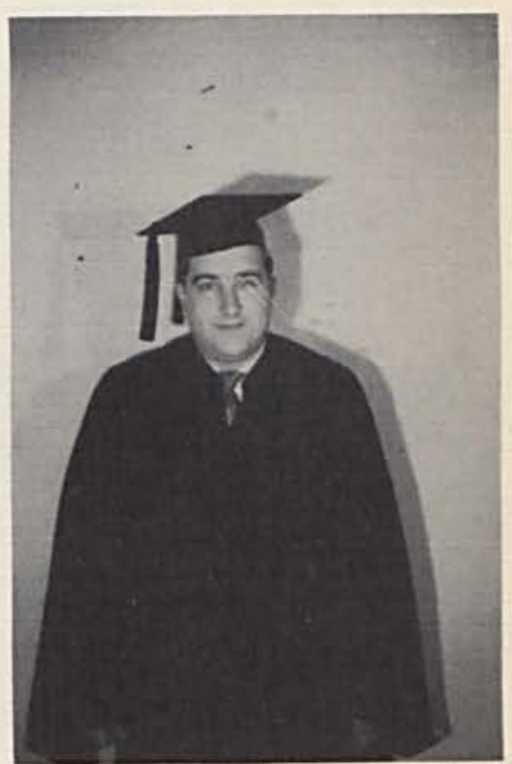

EUGENE FISHER

Watterbury, Vt.

B. S. in Education Teaches at Aberdeen, $\mathrm{O}$. 
PATRICIA ANN GRIEVE

\section{Xenia, Ohio}

B.S. in Ed. Teaches at Xenia, O.
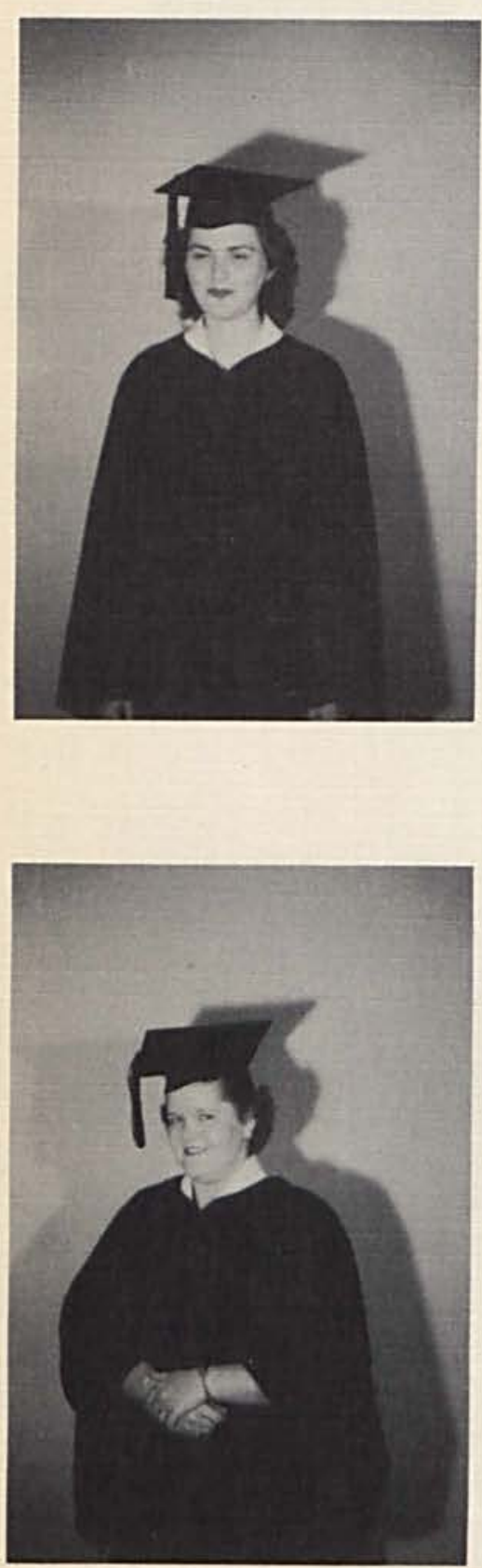

JEAN KING

Washington C.H., O.

B.S. in Ed. Teaches at Washington C.H.

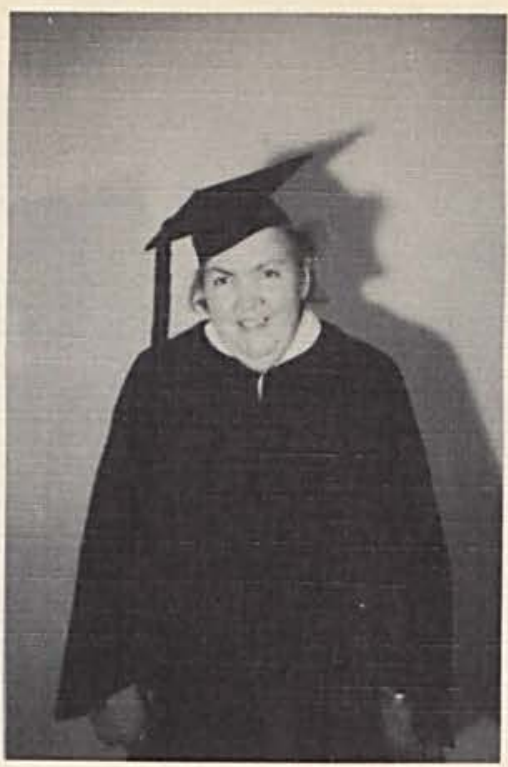

MARIE HARRINGTON Springfield, $\mathrm{O}$.

B. S, in Ed. Teaches at Delaware, 0 .
MYRA HA YDOCK

New Burlington, O.

B.S. in Ed. Teaches at New Burlington.

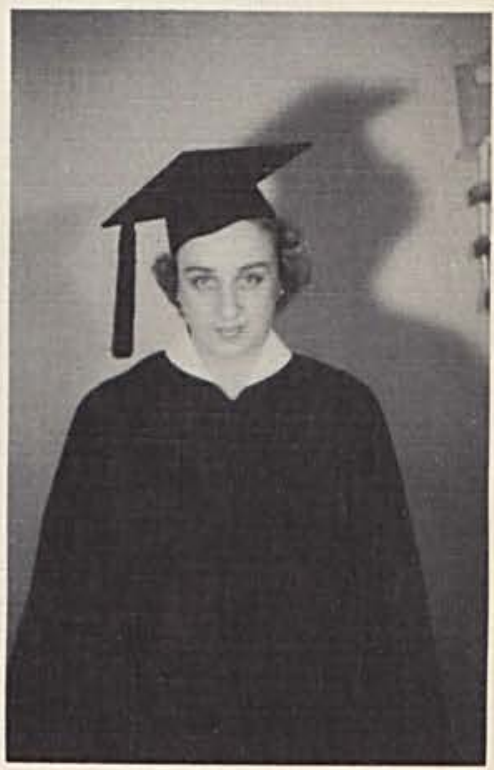

PAUL KLONTZ

Jamestown, $\mathrm{O}$.

B.S. in Ed. Teaches at S. Charleston, 0 .

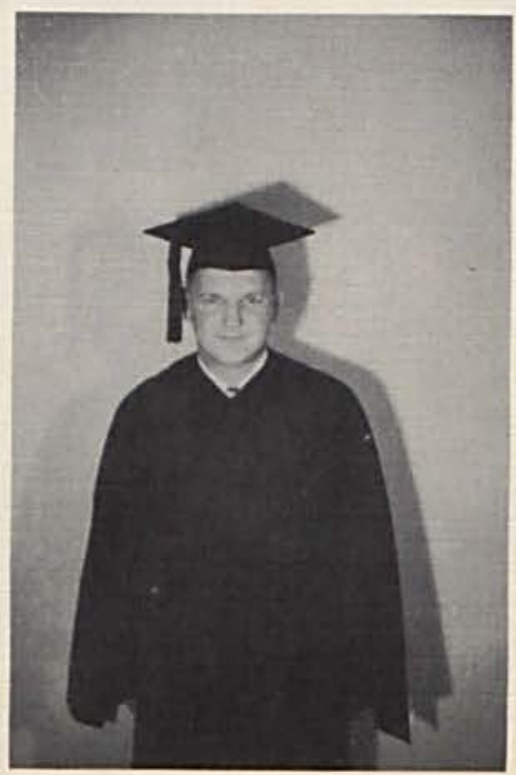

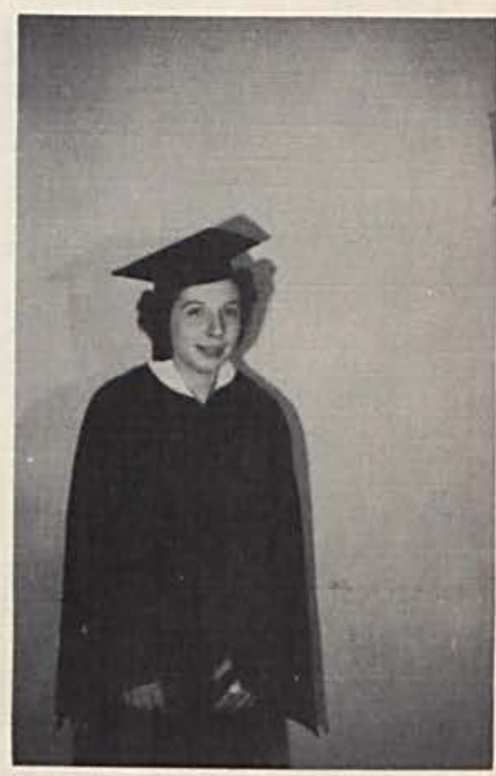

DONNA LORTON

Spring field, $O$.

B. S. in Ed. Teaches at Springfield, $O$. 
THEMLA LYNN

Otway, $O$.

B.S. in Ed. Teaches at Otway, $O$.
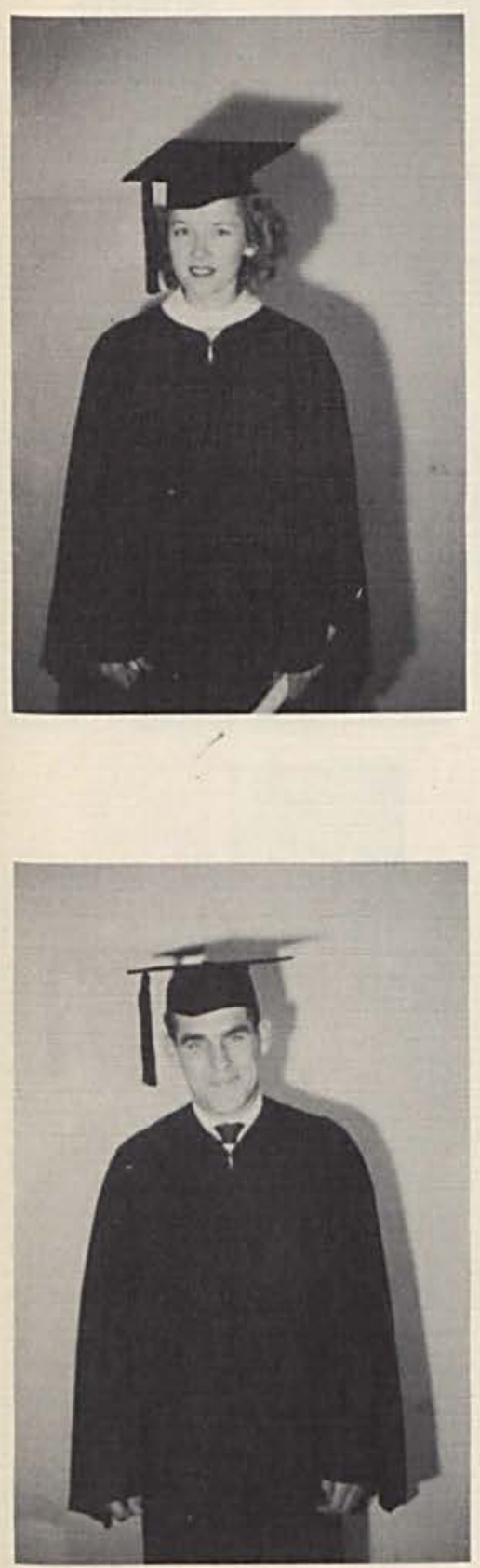

ROBERT PETERS

Cedarville, $\mathrm{O}$.

B.S. in Ed. Attending U. of Alabama.

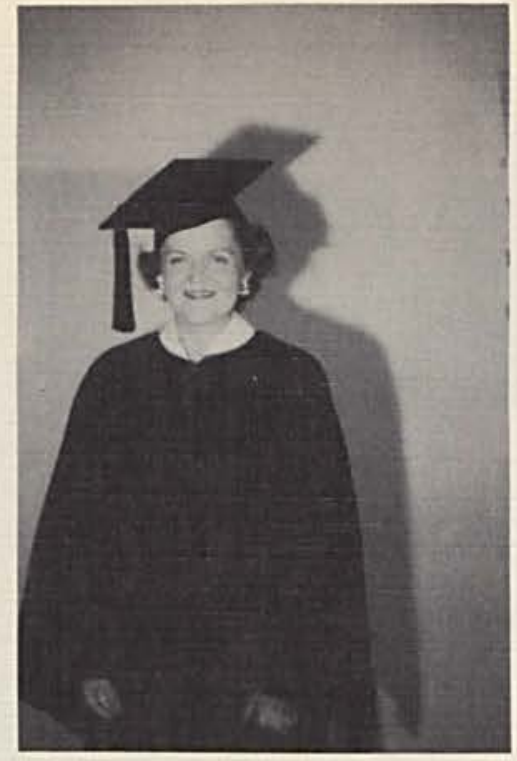

JANE McVEY

Xenia, O.

B. S. in Ed. Teaches at Dayton, O.
THOMAS OSBORNE

South Point, $O$.

B. S. in Ed. Teaches at Kitts Hill, $\mathrm{O}$.

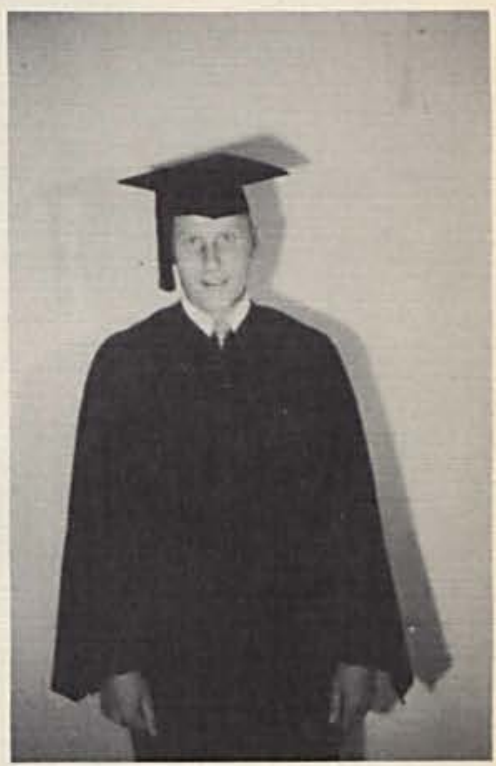

\section{FRANKLIN PICKENS}

Jamestown, O,

B. S. in Ed. Teaches at South Solon, 0 .

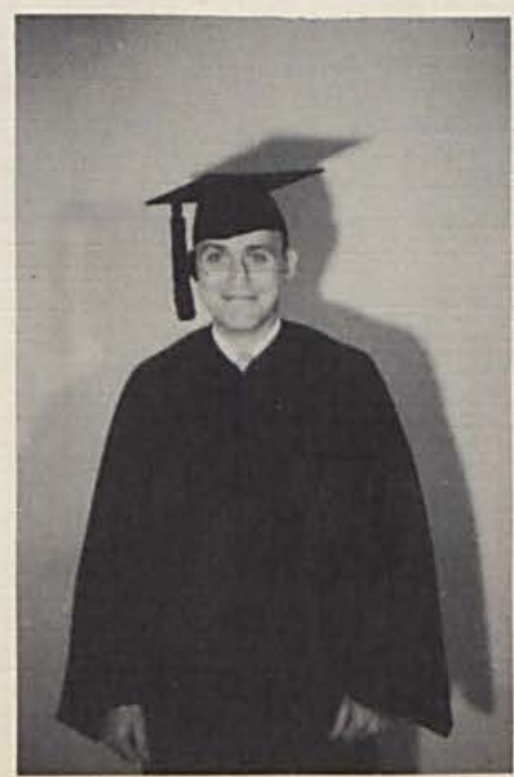

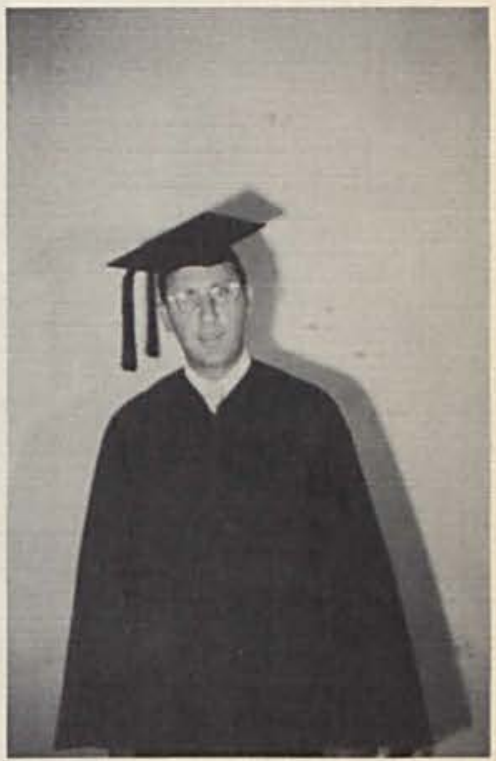

CHARLES PRESTON Lucasville, $\mathrm{O}$.

B. S. in Ed. Teaches at Lucasville, $\mathrm{O}$. 


\section{ALSON SCRIVNER}

Hamilton, $\mathrm{O}$.

B.S. in Ed. Tea ches at Piqua, O.
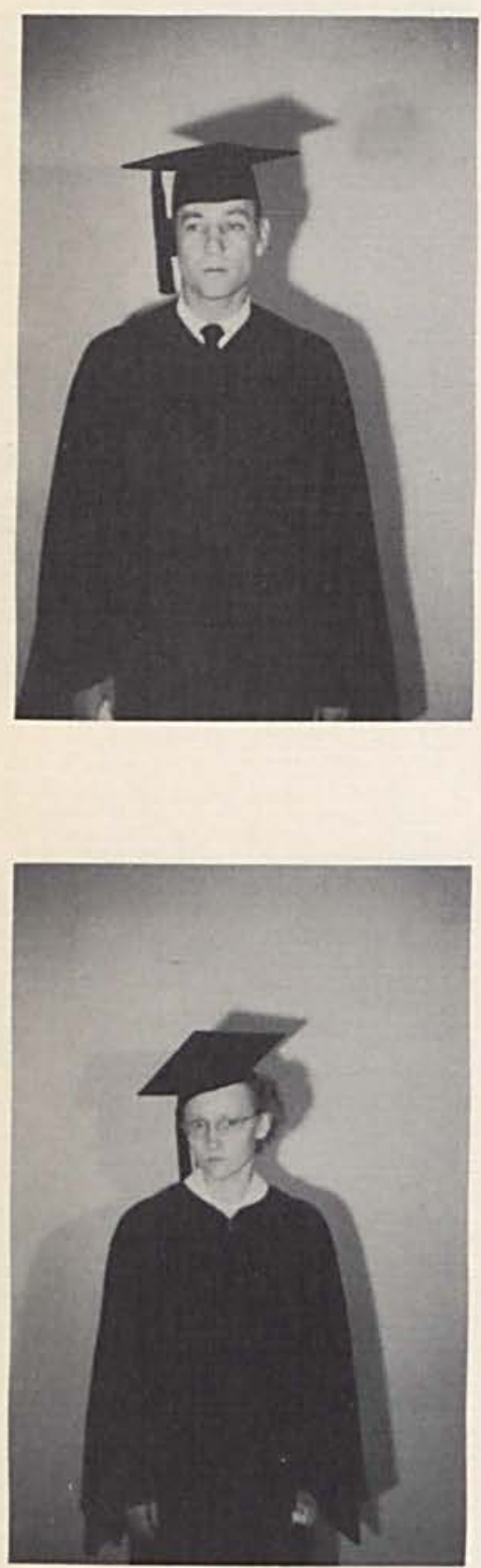

EULA SMITH

Springfield, O.

B. S. in Ed. Teachers at Springfield, $O$.

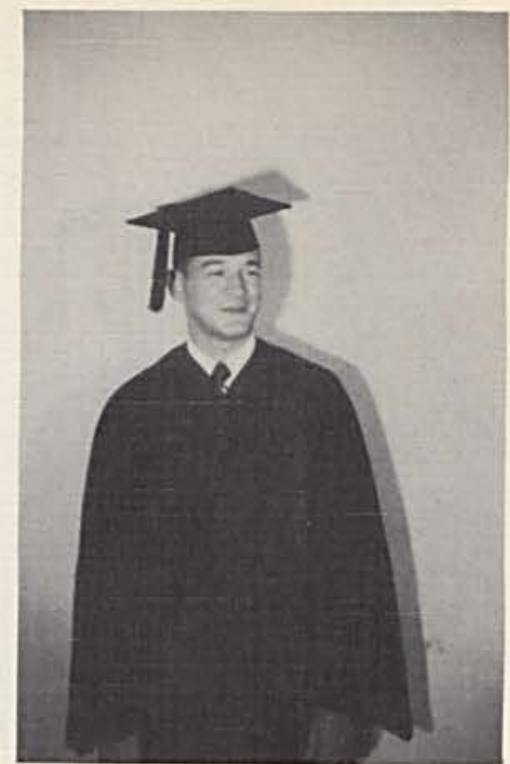

WALTER SEWAK

Springfield, $O$.

B. S. in Ed. Employed at Dayton, $\mathrm{O}$.
GLEN SHUMATE

South Webster, O.

B.S. in Ed. Air Force

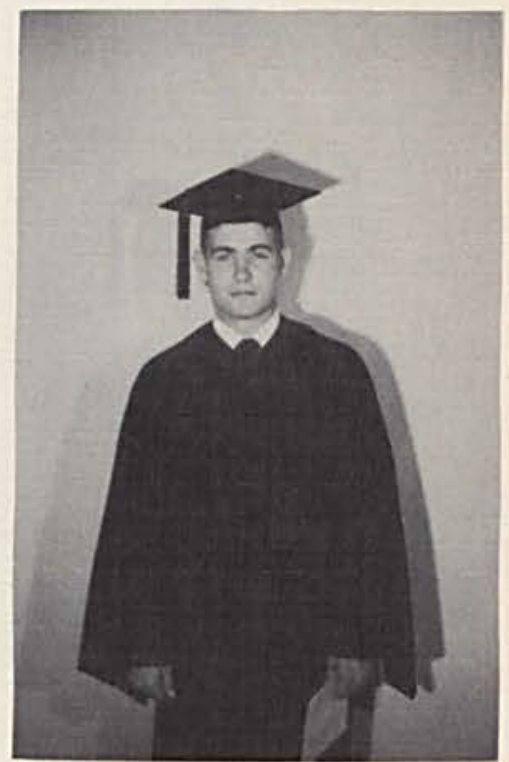

\section{RICHARD SMITH}

Xenia, $O$.

B. S. in Ed. Teaches at Brighton, $\mathrm{O}$.

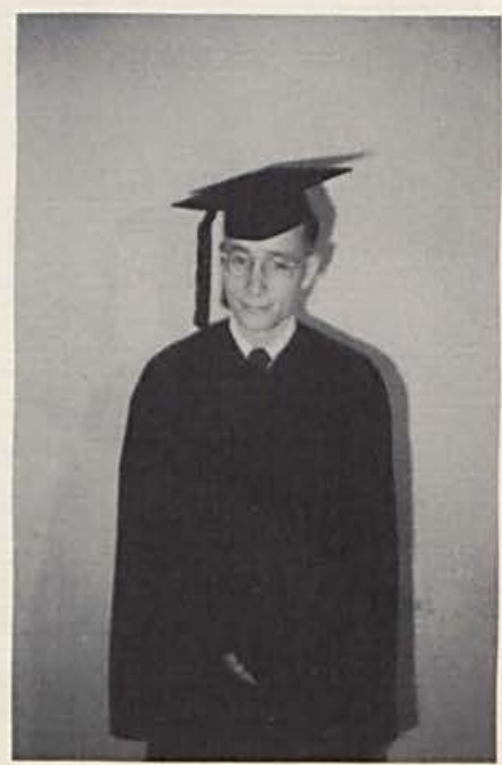

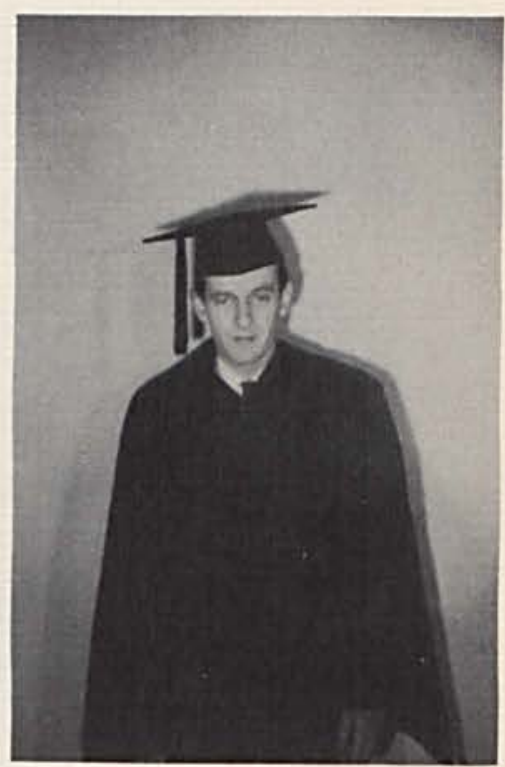

RICHARD WRIGHT

Cedarville, $\mathrm{O}$.

B. S. in Ed. Teaches at Northwestern Local Clark County, O. 

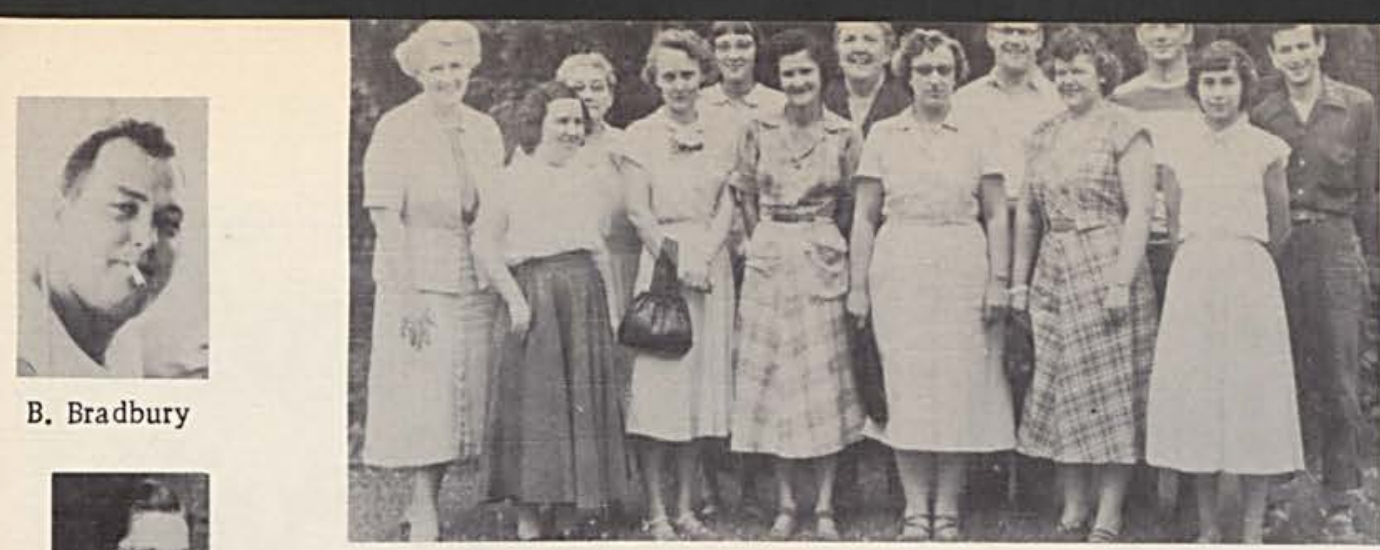

G. Anderson, E. Smith, R. Woods, M. Haydock, J. King, N. Cresswell, Prof. Herr, L. Roseberry, M. Miller, M. Har-
rington, W. Cultice, W. Sewak, R. Wright.

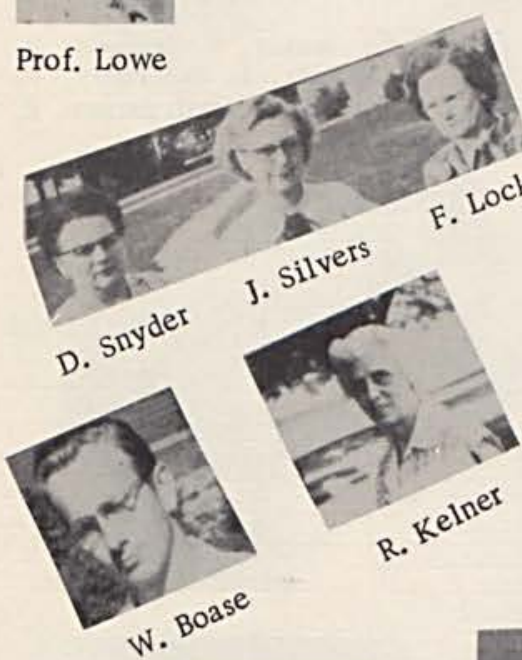

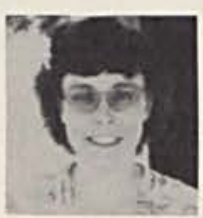

E. Bach

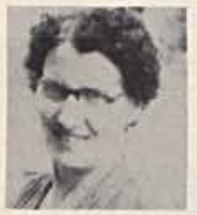

T. Sherer

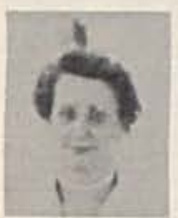

I. Whiteside

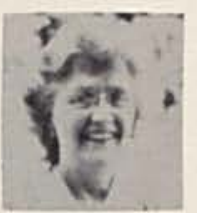

Prof. Corry

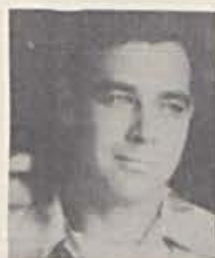

E. Borders

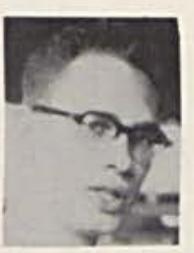

R. Sharp

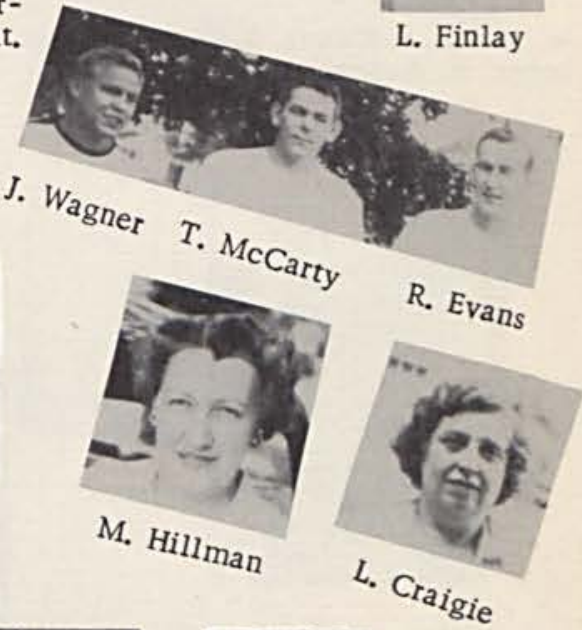

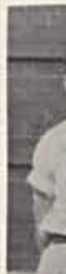

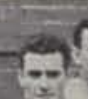

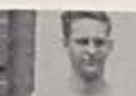
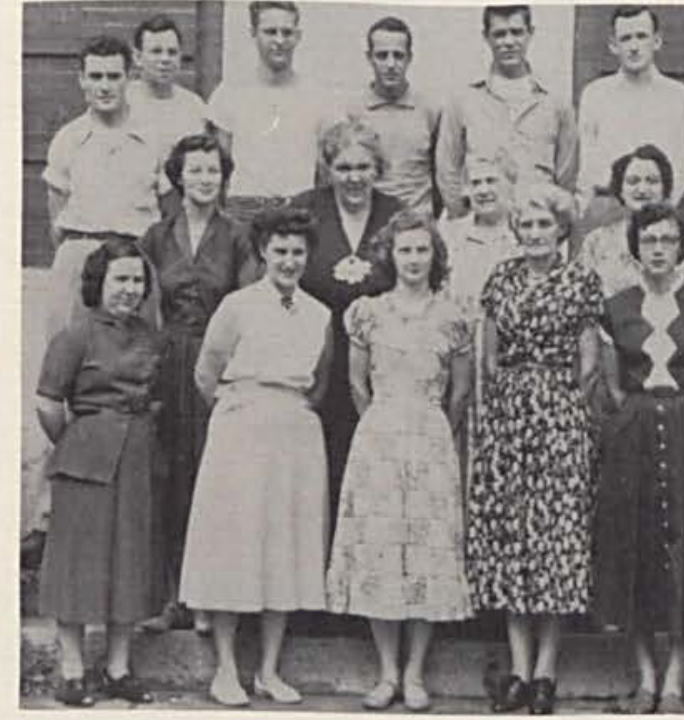

1ST ROW. G. Anderson, V. Estep, L. Flannery, D. Wells; Prof. Blaicher. 2ND ROW. M. Evans, M. Harrington, V. Crowder, E. Tiffany. 3RD ROW. V. Francis, J. Price, R. Hobbs, T. Webster, E. Sowell, Prof. Edington.

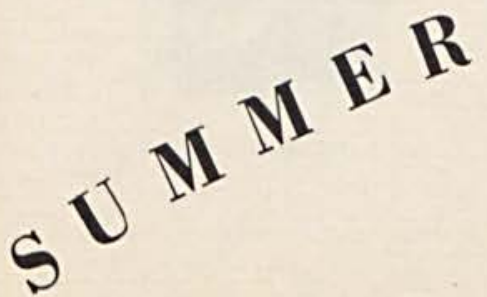

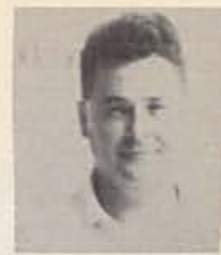

R. Cavender

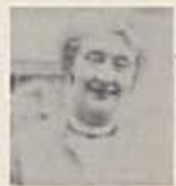

L. Finlay 


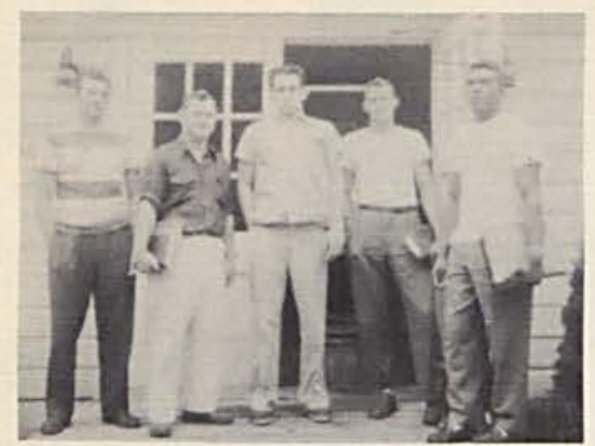

W. Sewak, P. Klontz, B. Peters, T. Osborne, H. Burton.

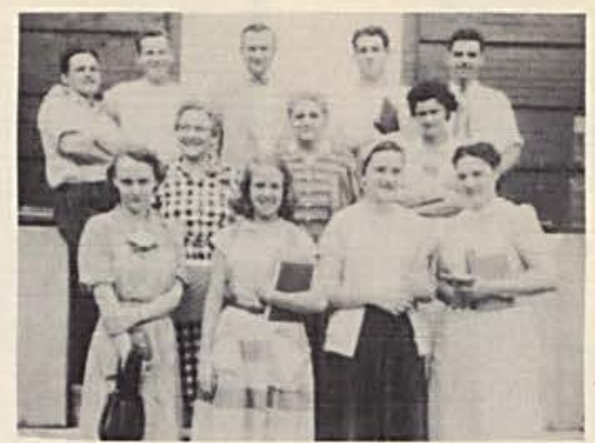

E. Smith, C. Warix, P. Gossett, R. Ramsey, R. Fenner, L. Roseberry, R. Wood, J. Dill, G. Cox, Prof. Jansen, B. Peters. Prof. Ramsey.

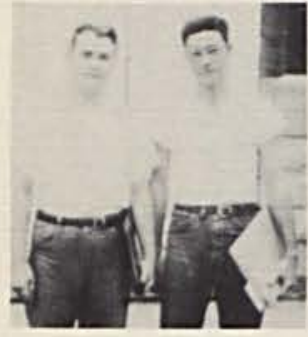

R. Miller, M. McClure

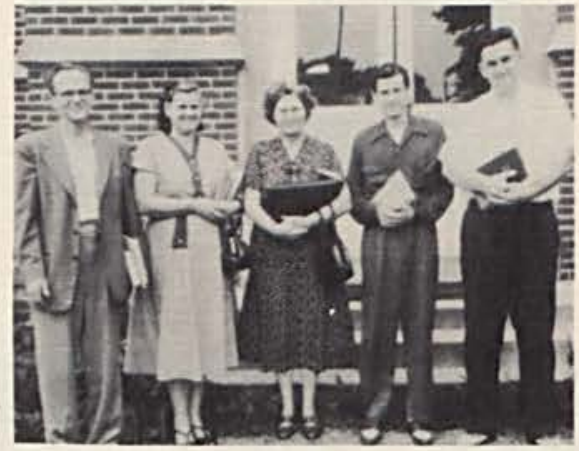

N. James, M. Adams, M. Daniels, R. Wright, Prof. Dodd.

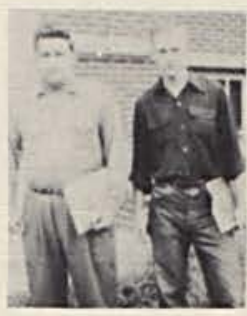

E. Fisher, D. Staggs

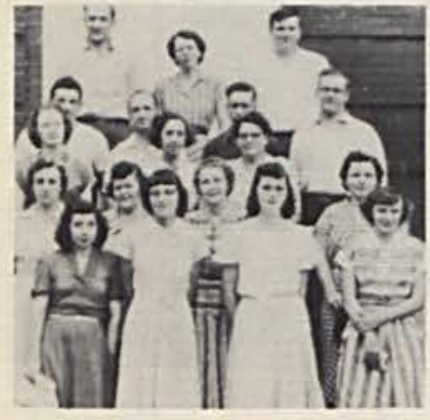

D. Lorton, M. Miller, P. Grieves, R. Spitzer, M. Haydock, J. King, G. Mitchell, G. Ackerman, D. Harris, N. Shaw, C. Salisbury, R. Martin, C. Thomas, R. Smith, W. Cultice, Prof. Kynn, Prof. Diehl, Prof. Shaw.

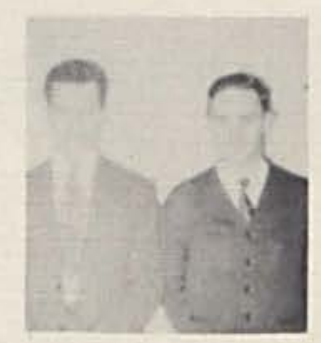

V. Brantley, V. Shaw

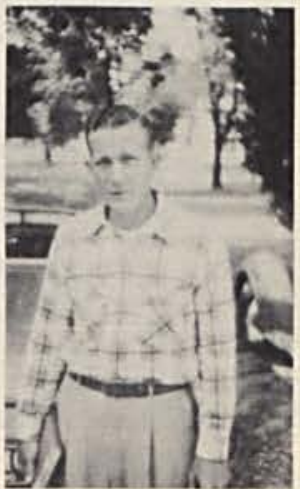

E. Goodwin 

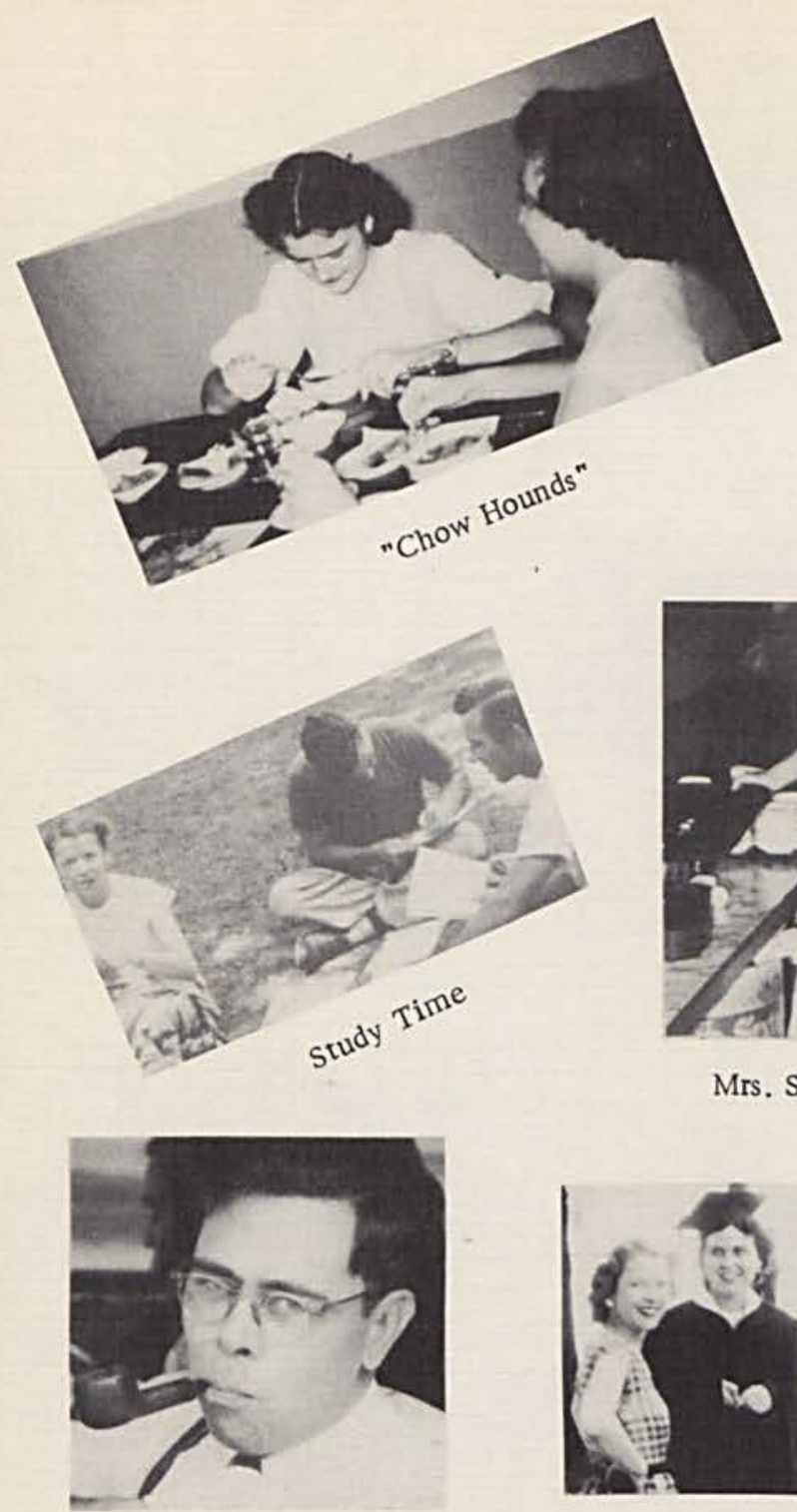

Phillip Shupp, Esq.

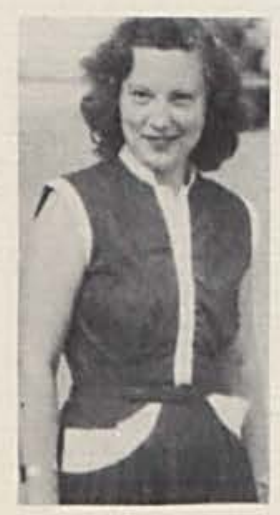

Viola Thurman

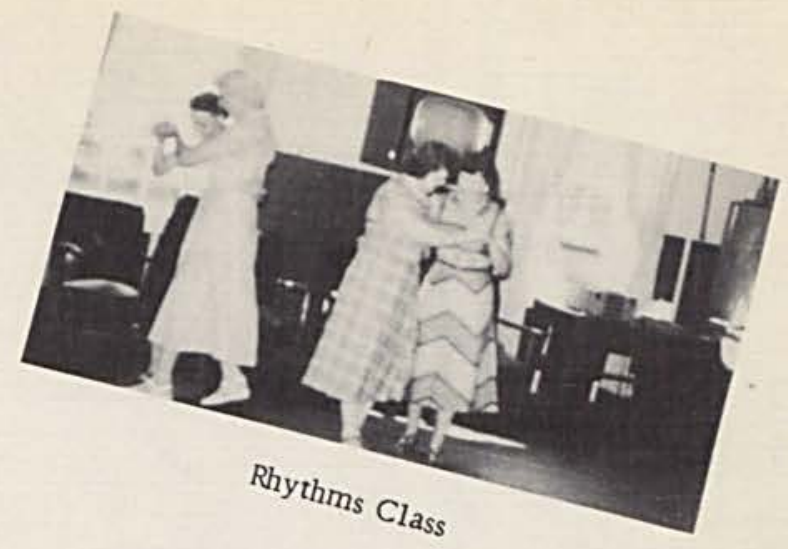

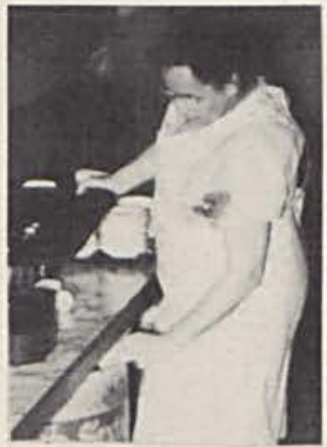

Mrs. Spracklin

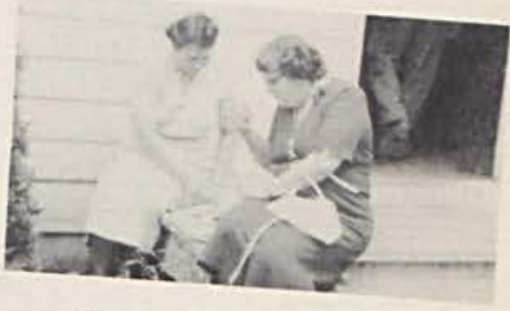

Summer School Picnic Linnie Hagen, L. Moyer

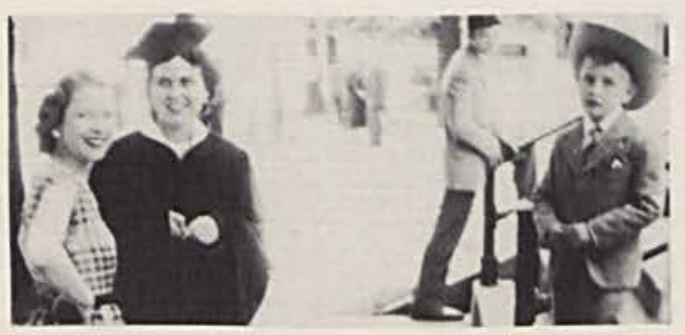

After Graduation

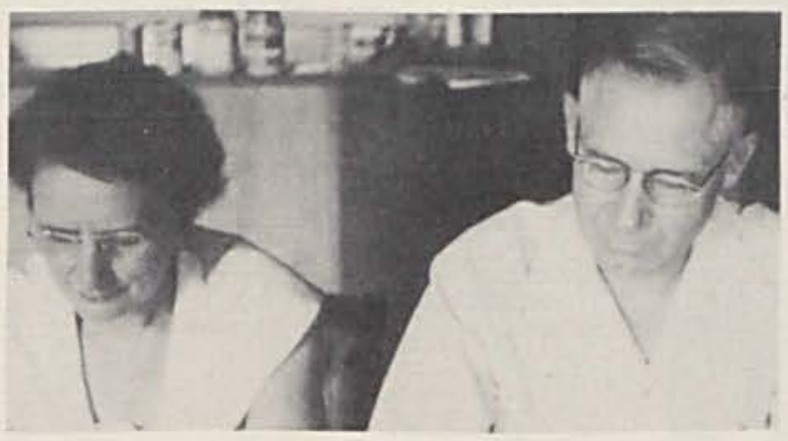

Grandma \& Grandpa Whiteside

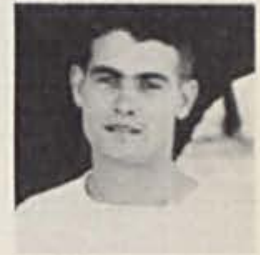

Glenn Shumate of South Webster

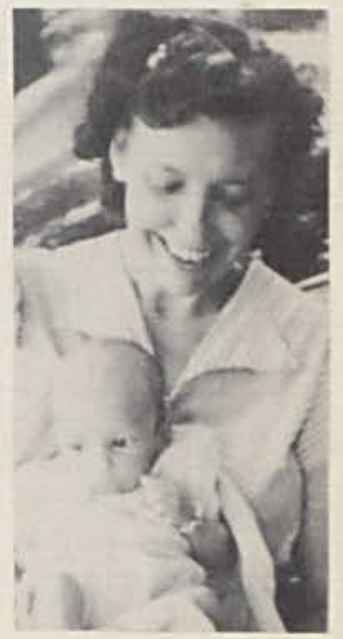

Jane \& Joe Price, Jr. 

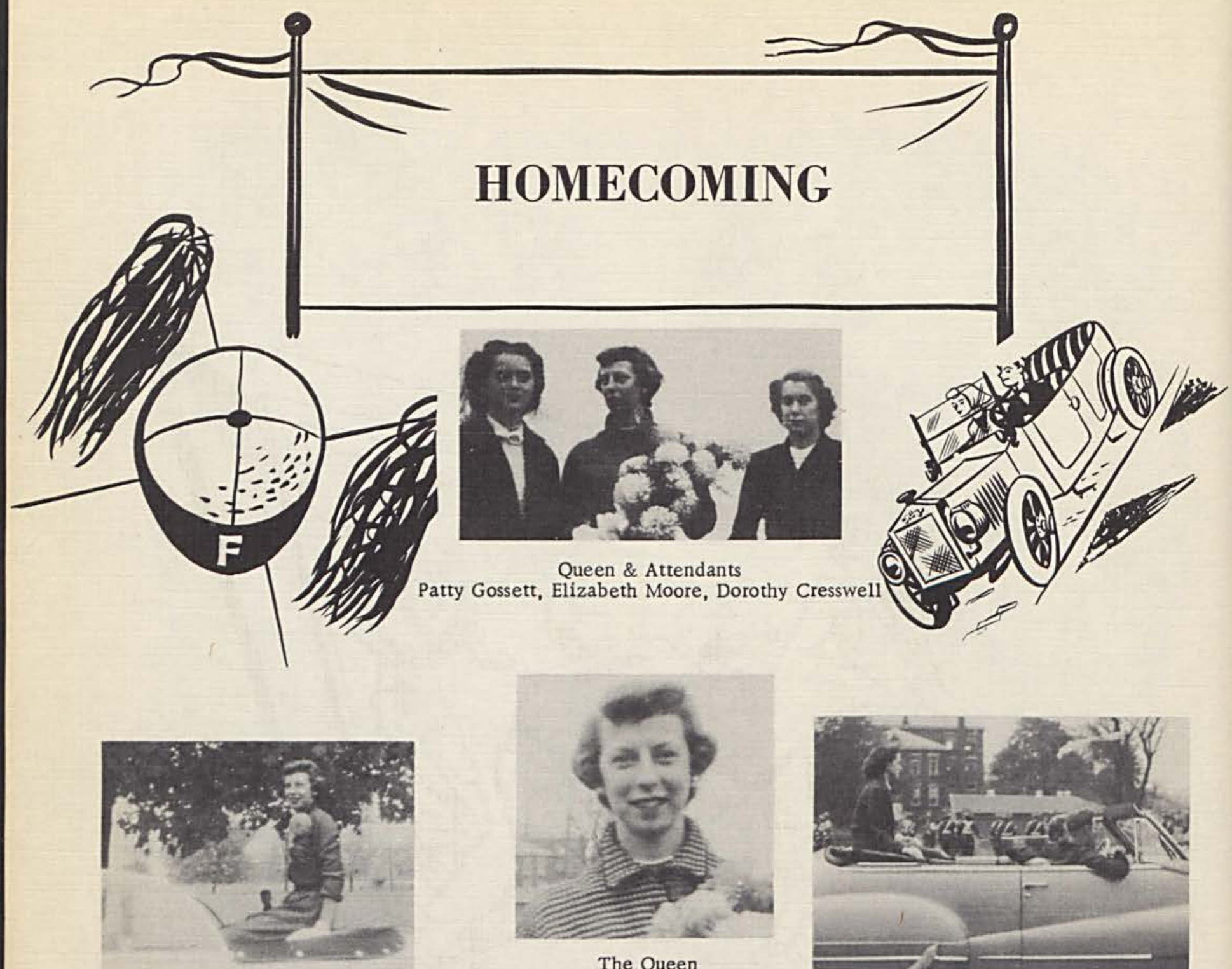

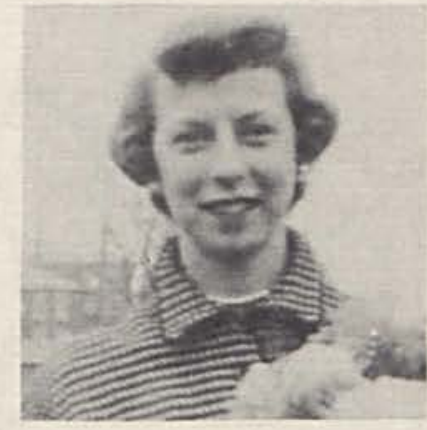

The Queen

Elizabeth Moore

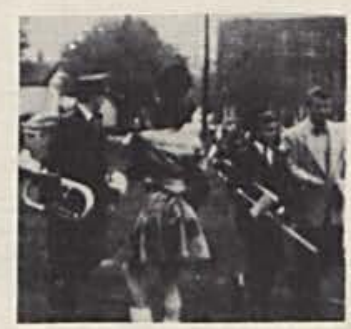

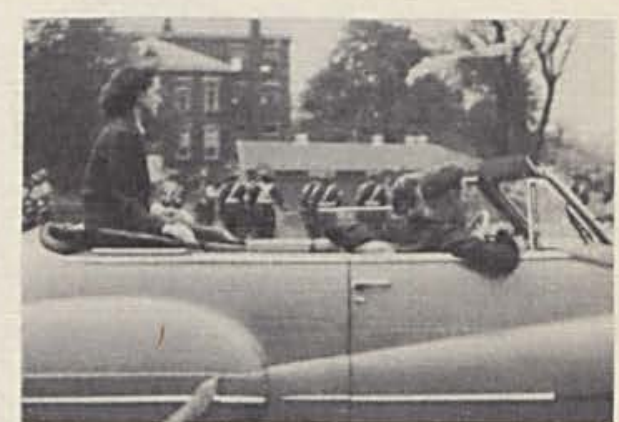
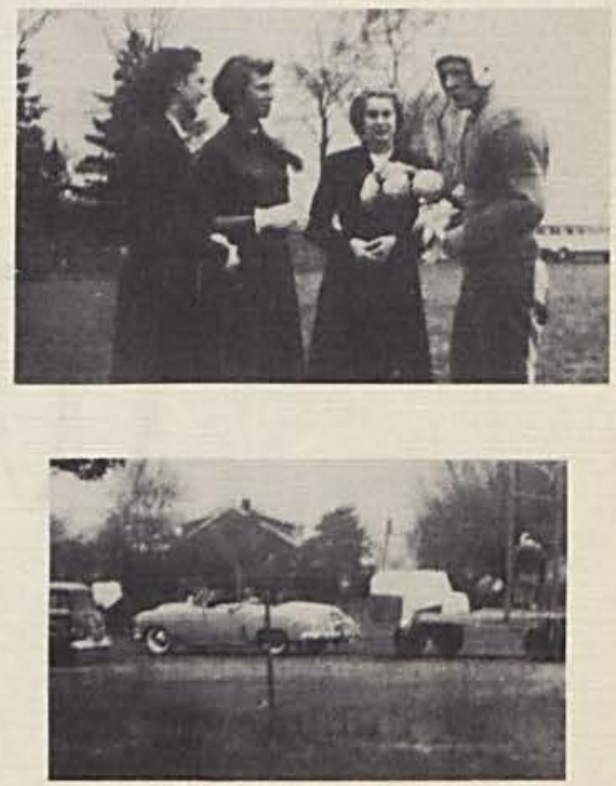

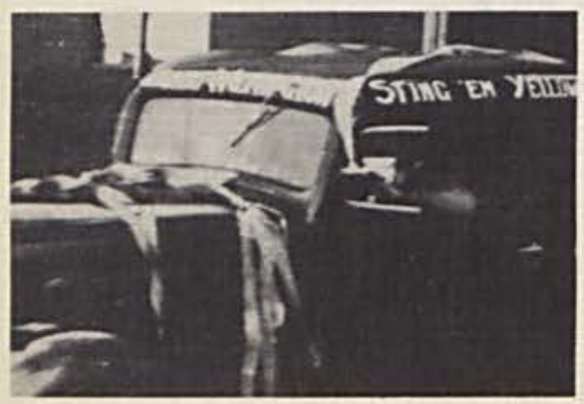




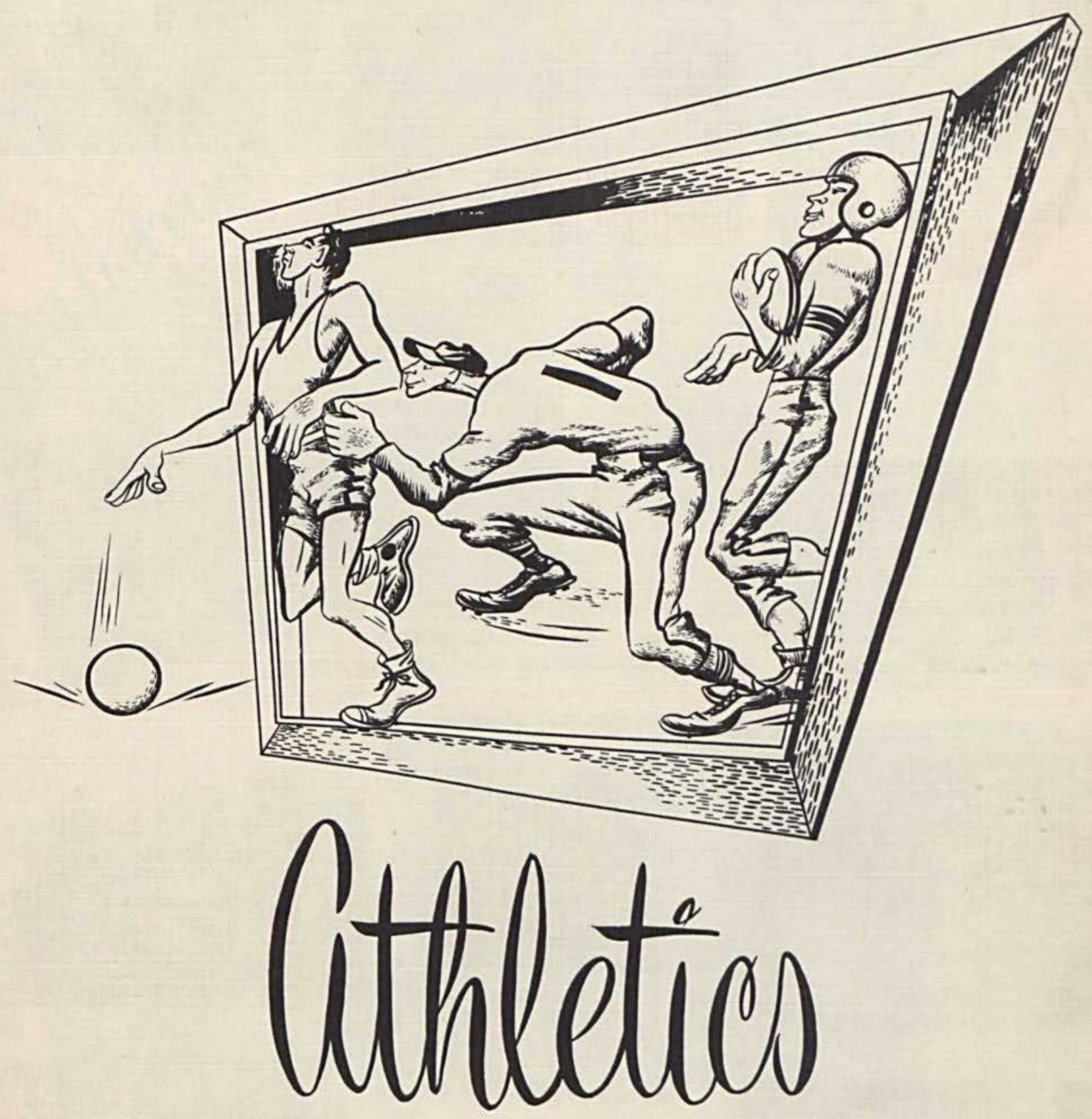




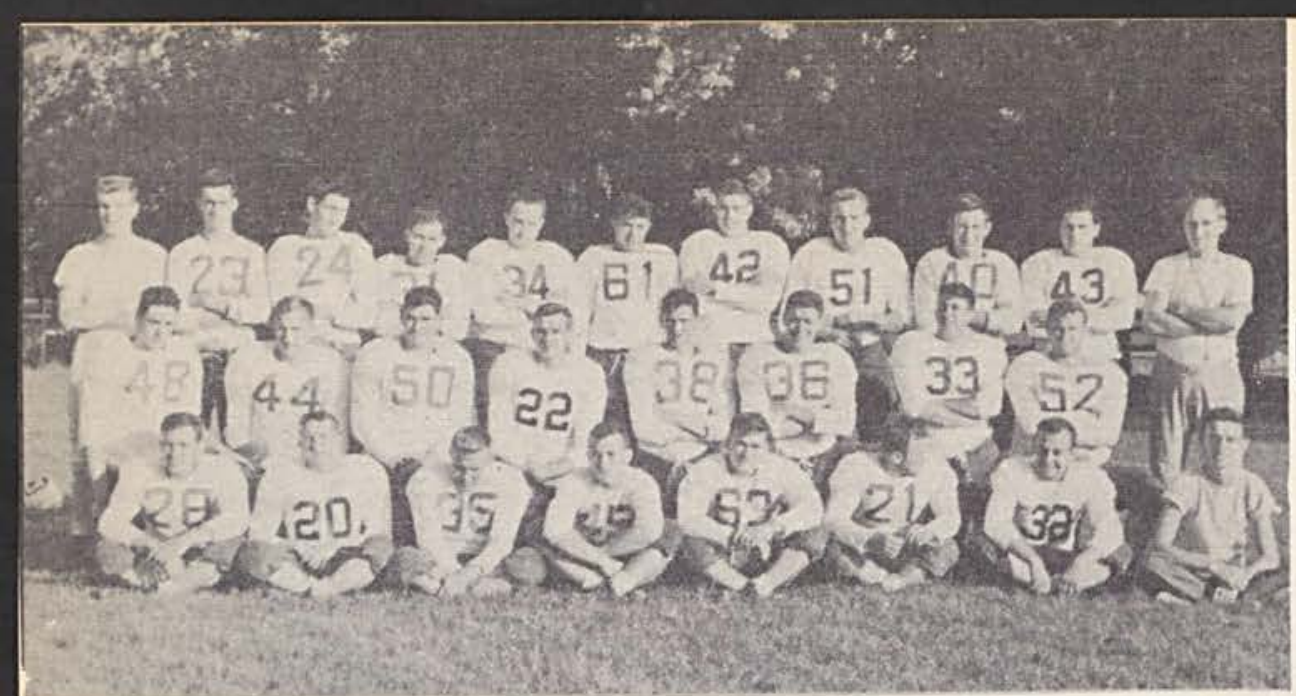

1st Row-J. Trinkle, D. Spitzer, J. Wagner, K. Carpenter, K. Woods, J. Nicolelia, G. Barlow, Mgr. Mann. 2nd row-R. Collins, D. Staggs, D. King, R. Syrek, R. Kidd, R. Burnett, J. Syrek, H. Schultz, Coach M. Kynn. 3rd RowAsst. Coach H. Stellings, J. O'Brien, P. Sheridan, E. Lewis, J. Irvine, A. Boutin, C. Bevis, E. Bauts, W. Joyce, R. Duffey
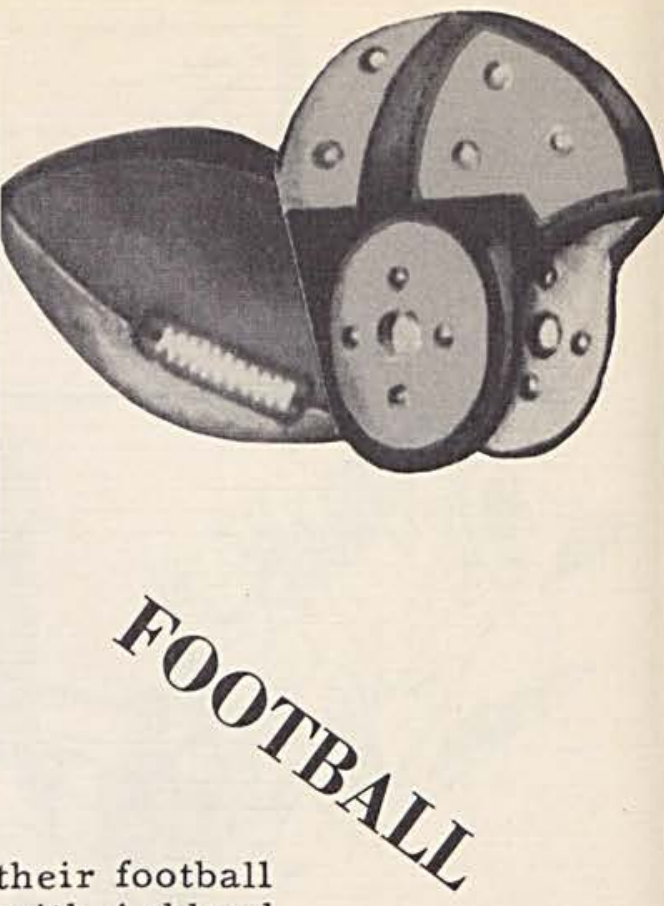

The Cedarville College "Yellow Jackets" ended their football season with two league wins which put them in a tie with Ashland College for third place in the Mid Ohio League.

One of the highlights of the season was the smart 27-20 defeat handed to Bluffton College who was co-champion with Findlay. The Kynn-men played a superb game against Findlay College. Cedarville was leading six to three going into the final quarter when an alert Findlay player blocked and recovered a punt on our 15 yard line. The touchdown which soon followed "broke our backs" and left a final score of 15 to 6 .

All considered, the Yellow Jackets ran up some impressive scores against much larger teams. The team is to be commended for their hard work both in training and on the playing field.
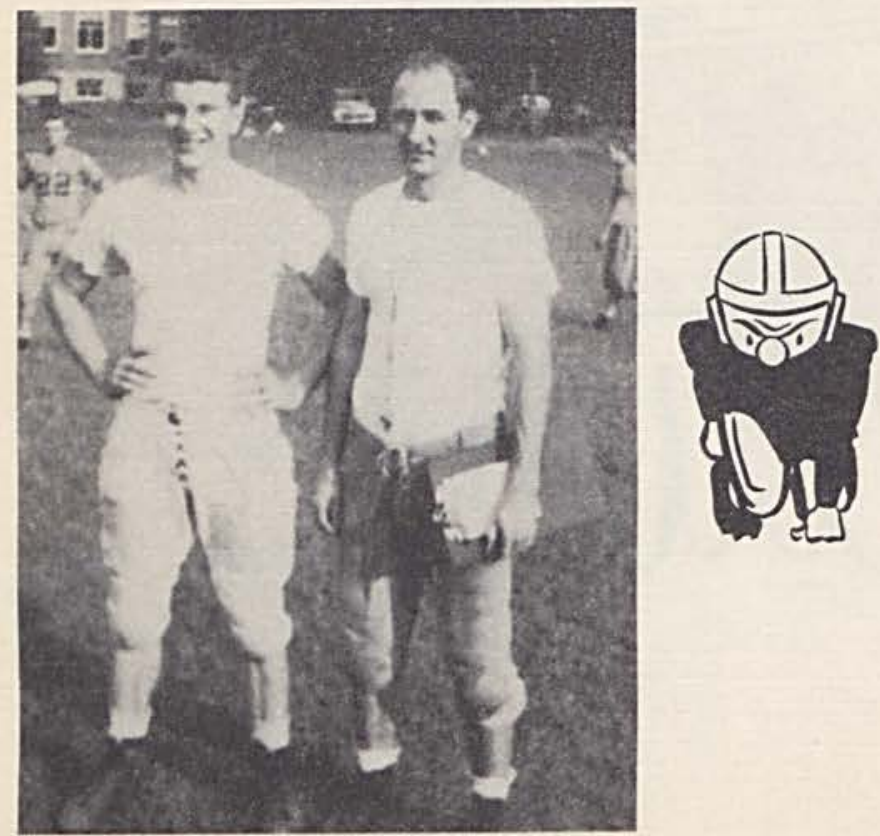

Sept. 13
Sept. 22
Sept. 29
Oct. 6
Oct. 13
Oct. 20
Oct. 27
Nov. 3

SEASONS RECORD

Asst. Coach Stellings,

Coach Kynn

CC. 0

CC. 6

CC. 13

CC. 20

CC. 13

CC. 6

CC. 0

CC. 6
Ohio Northern 28

Findlay

Ashland

Bluffton

Defiance

Indiana Central 20

Wilmington

Homecoming

Rose Poly
There

Home

There

Home

Home

There

Home

13 There 


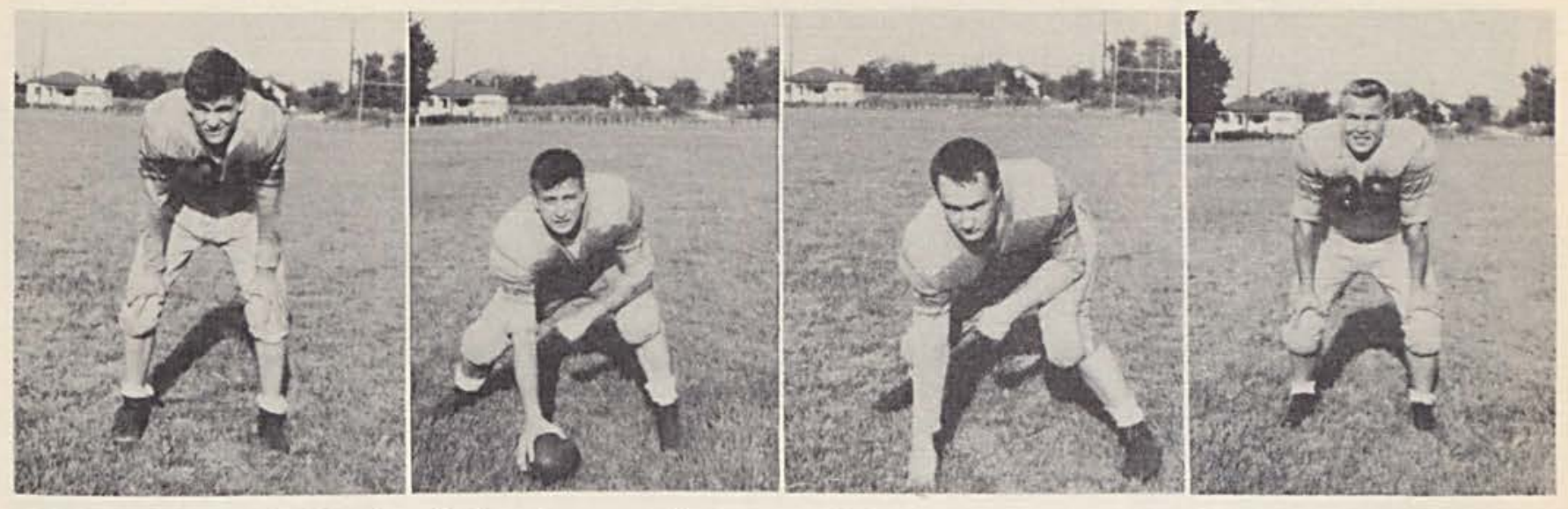
K. Woods
Fullback
J. Syrek
Center
J. Irvine
Guard
J. Wagner
Fullback
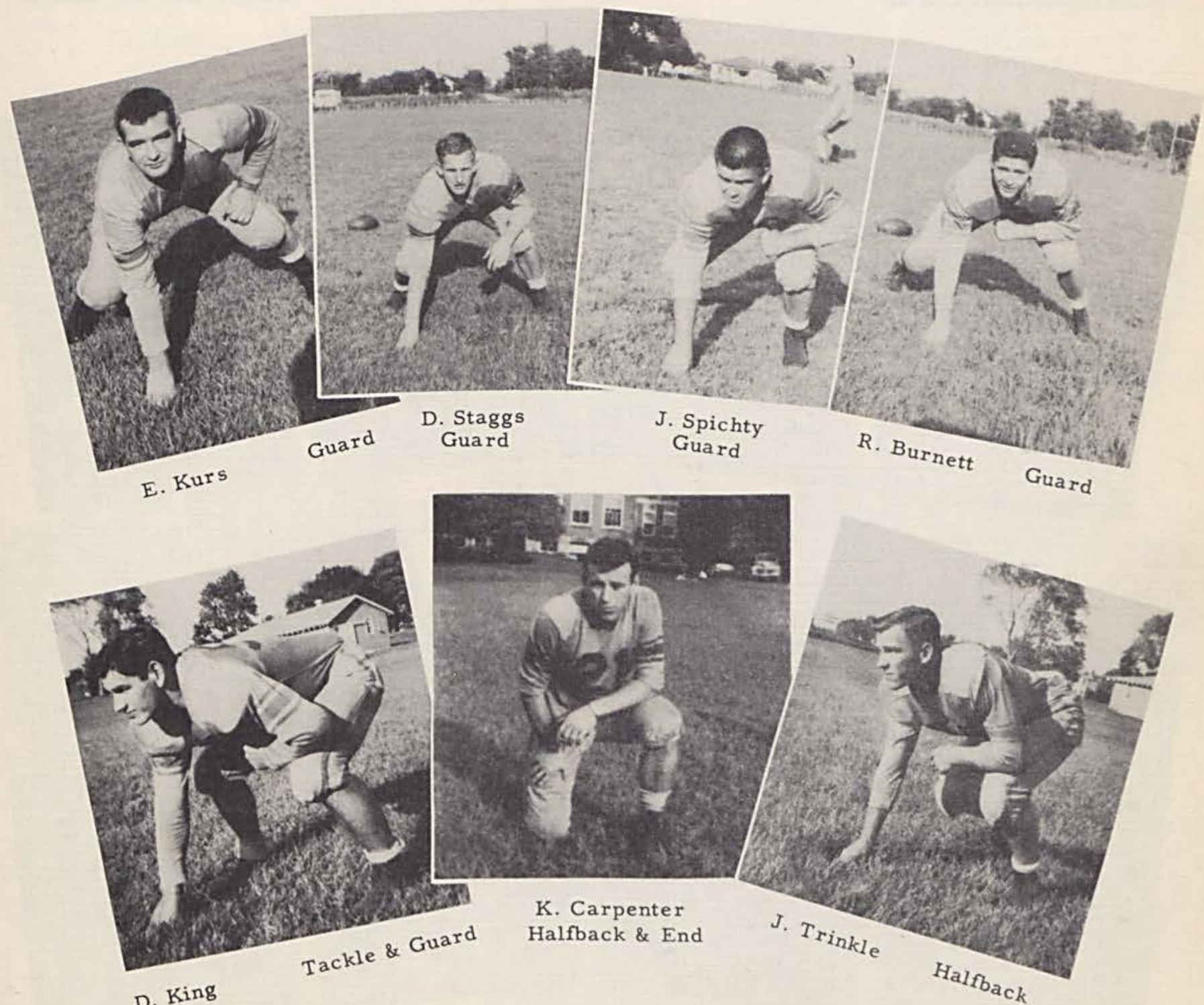

D. King

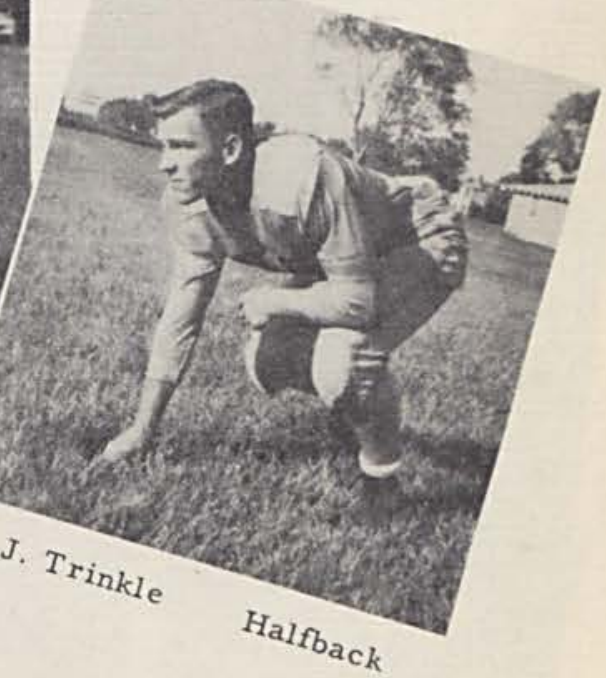




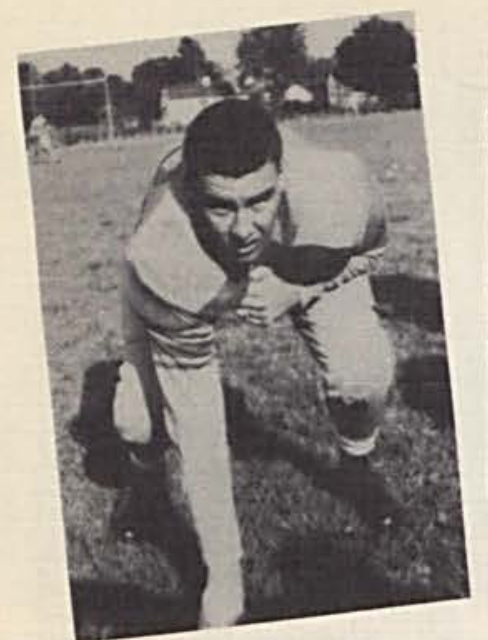

C. Bevis

Tackle

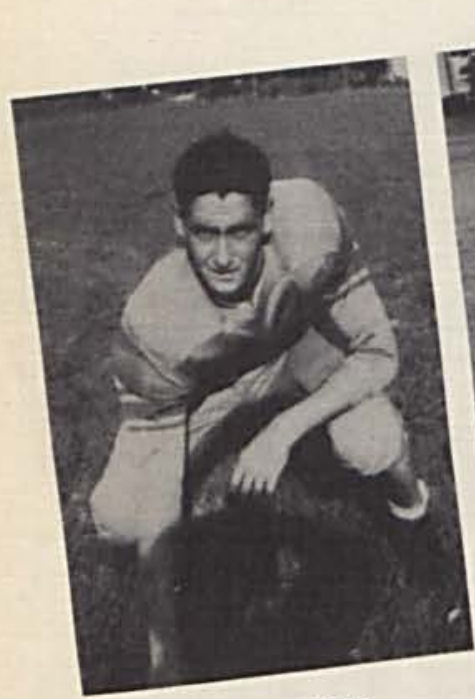

P. Sheridan Tackle, Halfback

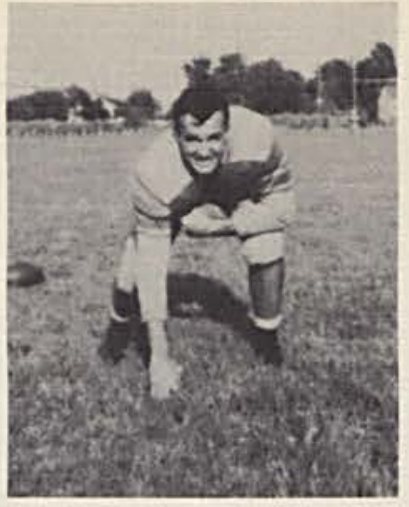

\section{J. Hartman
Tackle}

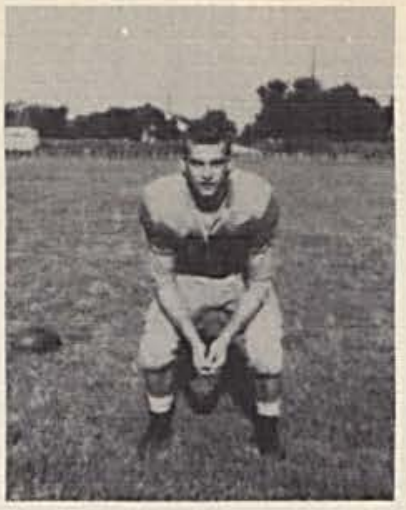

R. Syrek Halfback

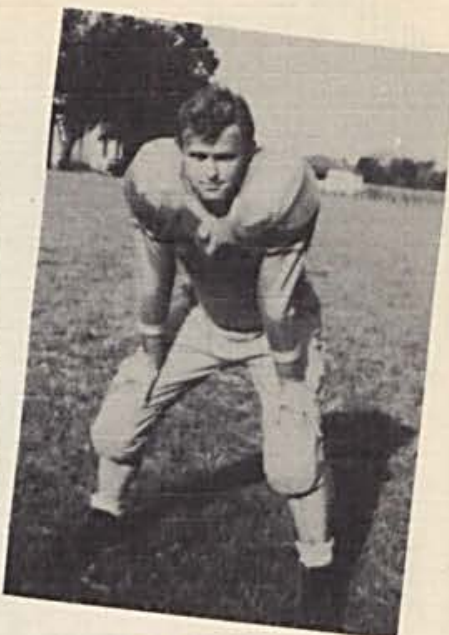

H. Schultz End

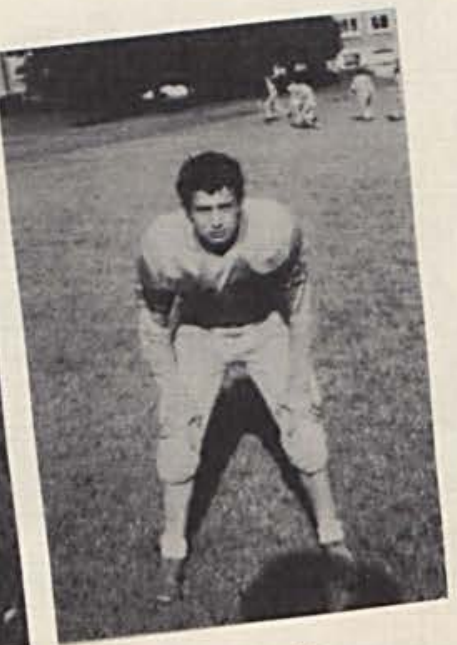

A. Boutin Halfback

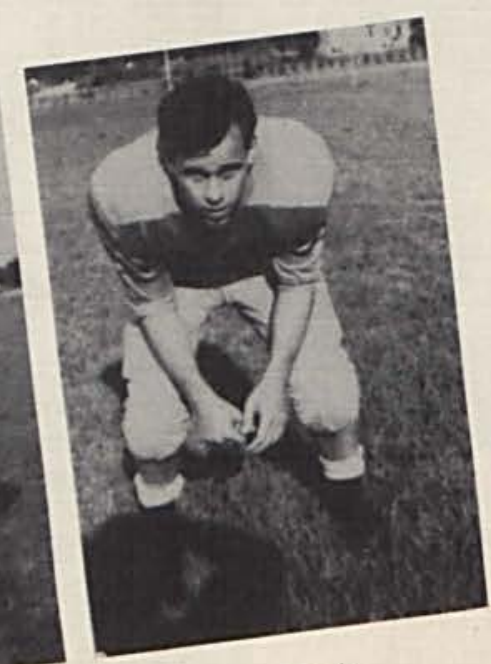

E. Lewis

Halfback

R. Duffy

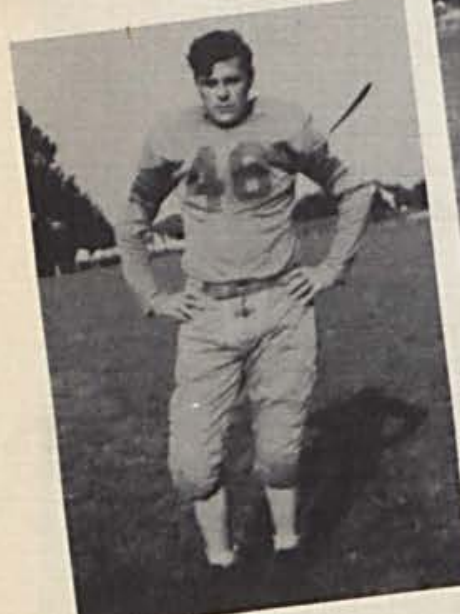

End

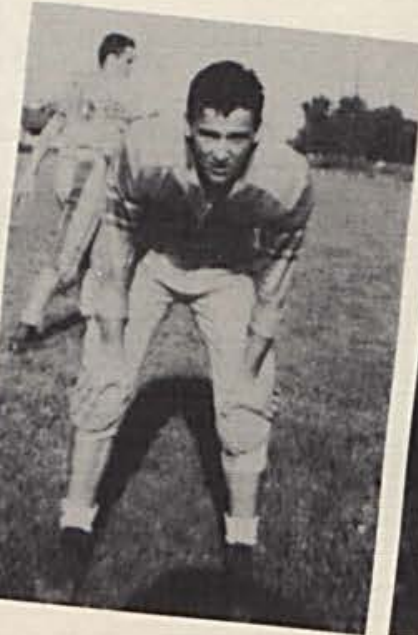

R. Kidd

End \& Halfback

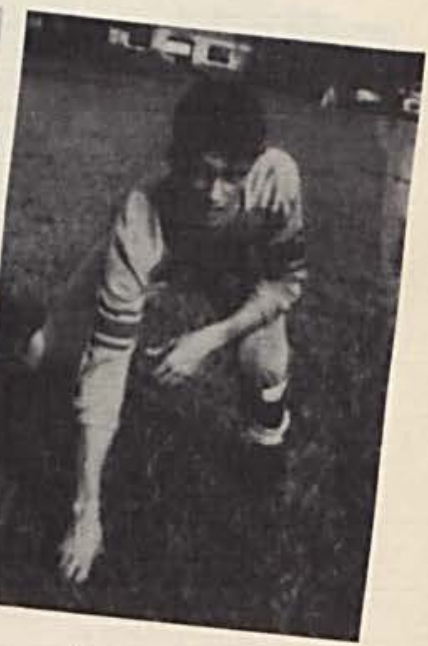

J. O'Brien
End

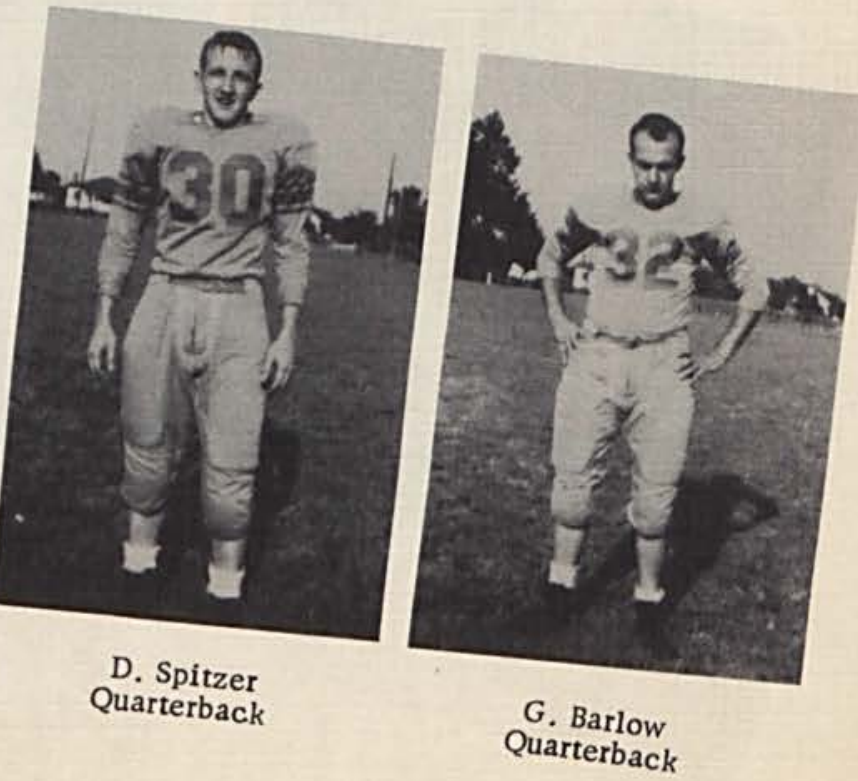




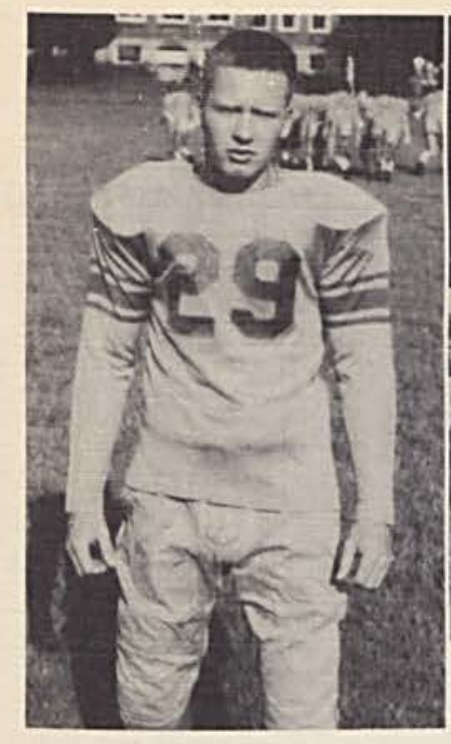

Al Glover

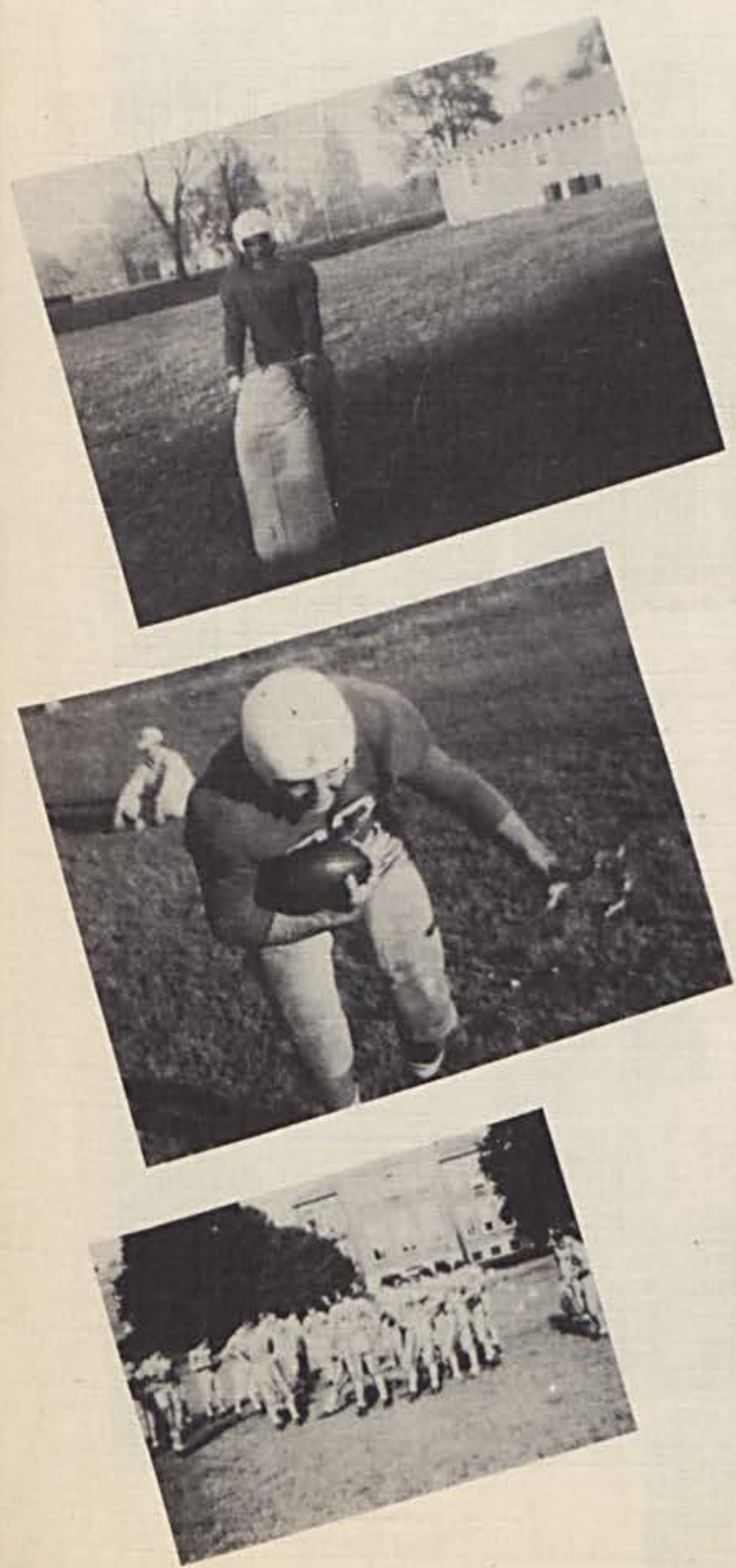

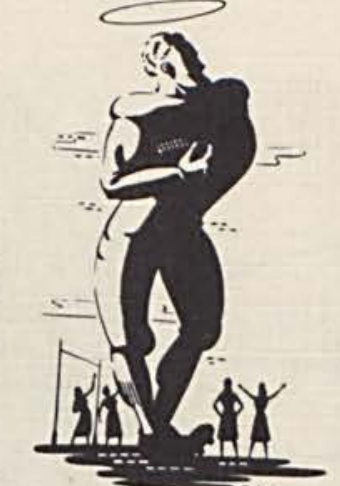

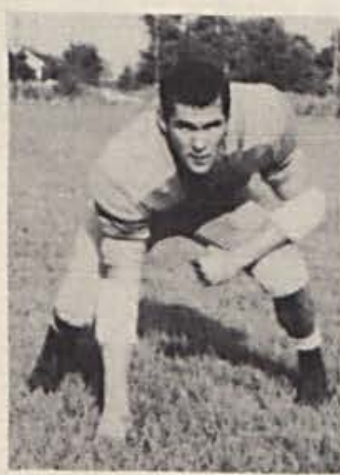

K. Innis End

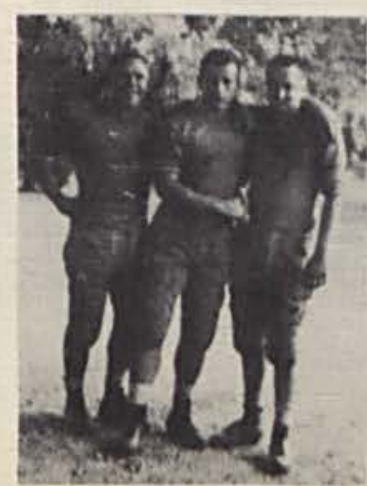

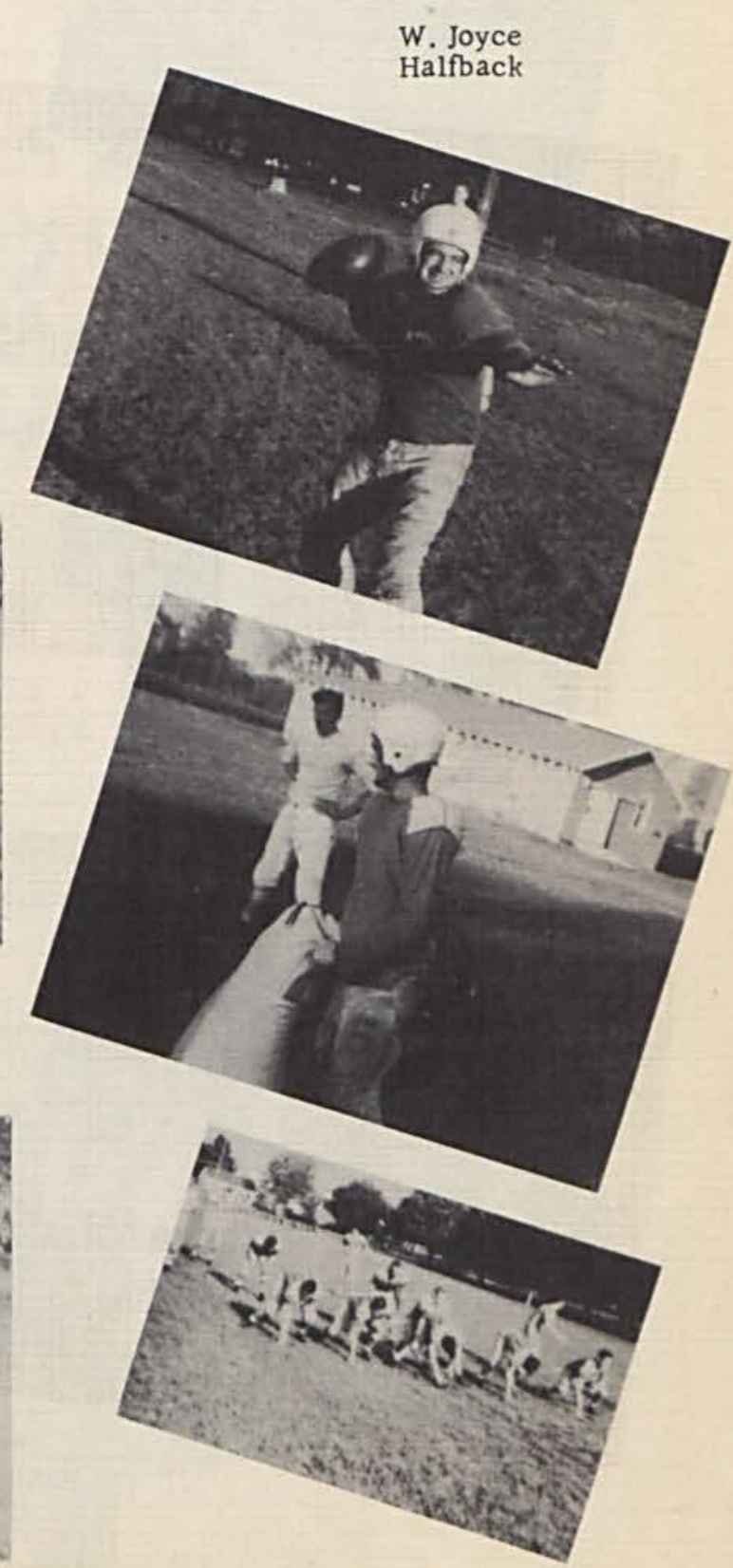




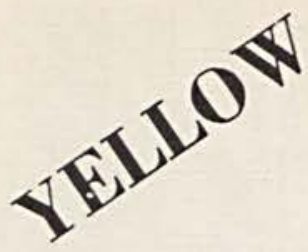

\begin{tabular}{|c|c|c|c|}
\hline \multicolumn{2}{|c|}{ SEASON'S } & ECORD & \\
\hline Ohio Northern & 28 & Cedarville & \\
\hline Findlay & 15 & & 6 \\
\hline Ashland & 40 & $"$ & 14 \\
\hline Bluffton & 20 & " & 27 \\
\hline Defiance & 7 & n & 13 \\
\hline Indiana Central & 20 & " & 7 \\
\hline Wilmington & 53 & " & 0 \\
\hline Rose Poly & 14 & $"$ & 7 \\
\hline
\end{tabular}
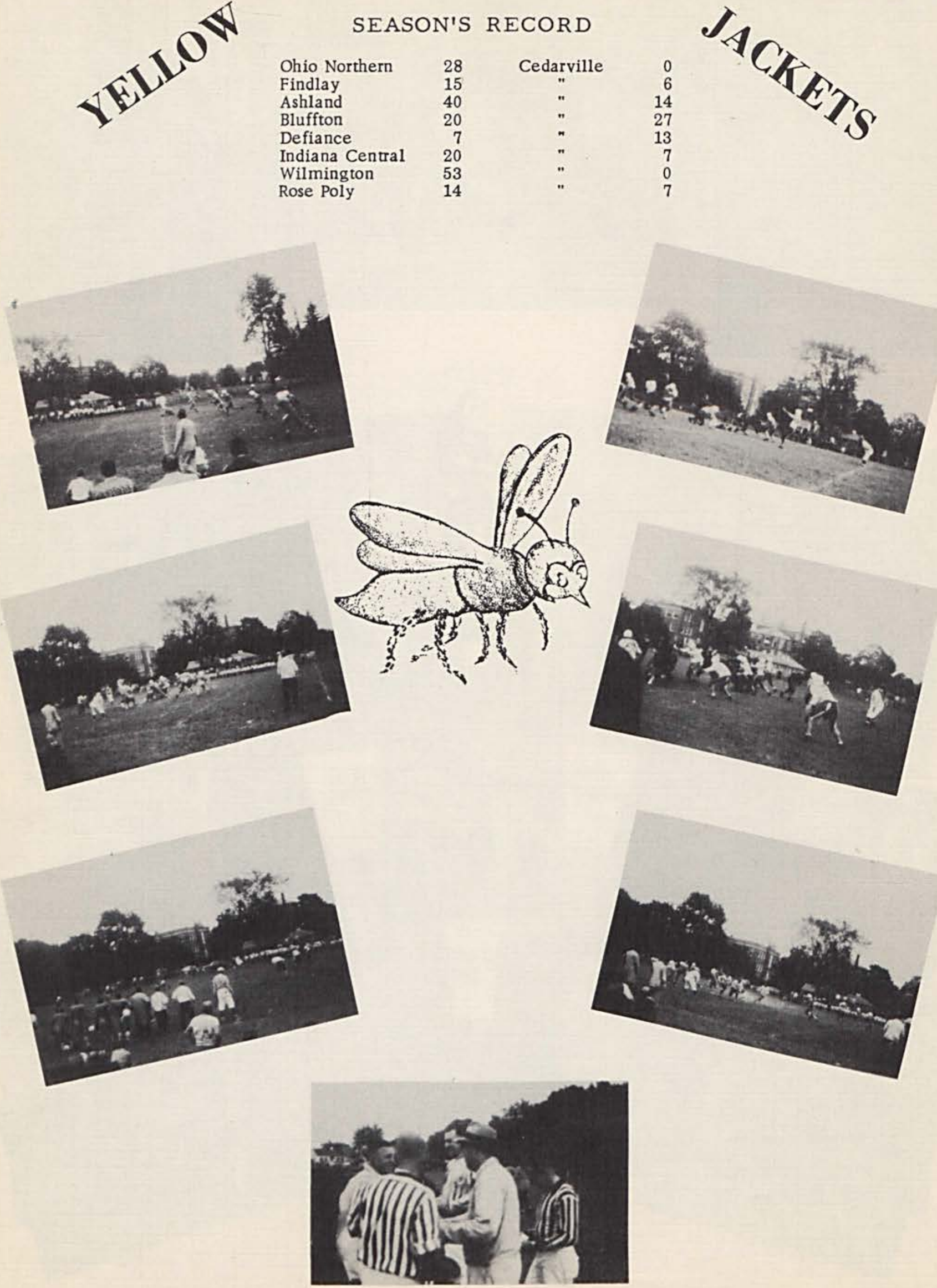


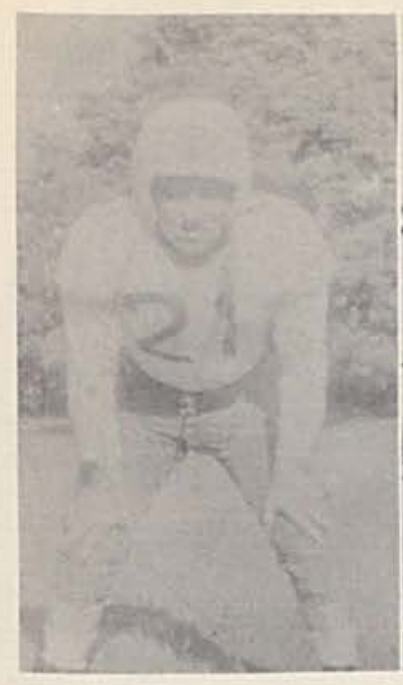

John Nicolella-

linebacker

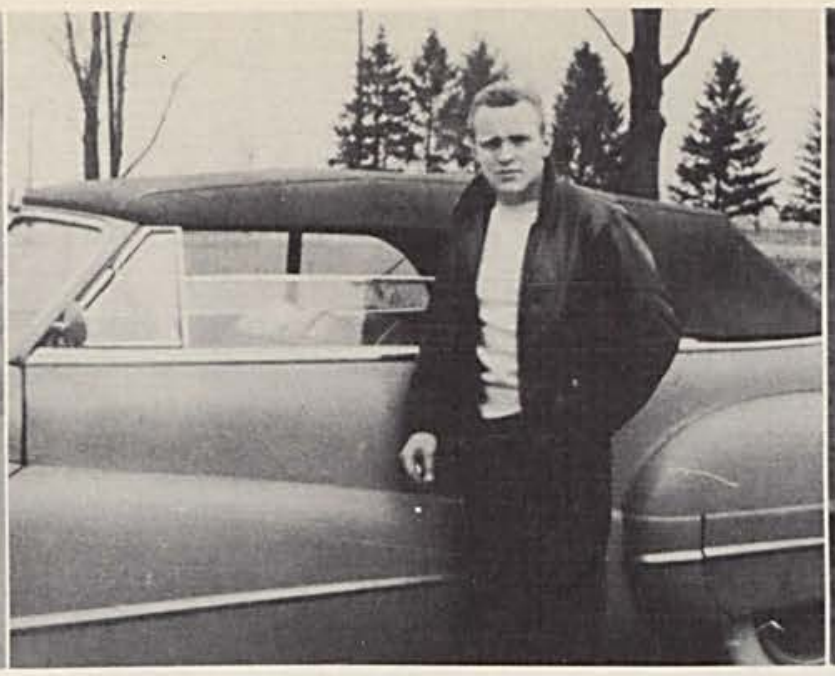

Eric Bauts

tackle

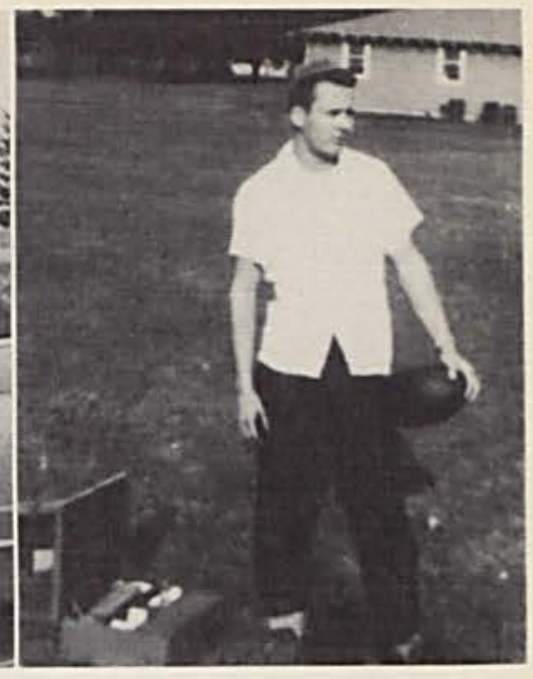

Al Glover

assistant manager and trainer

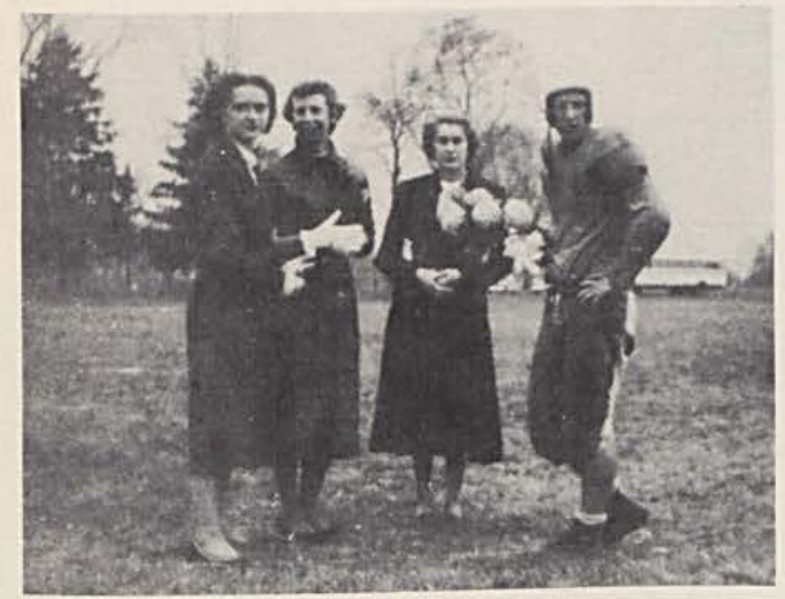

Pat Gossett, Elizabeth Moore, Queen, Dorthy Creswell, Don Staggs captain.

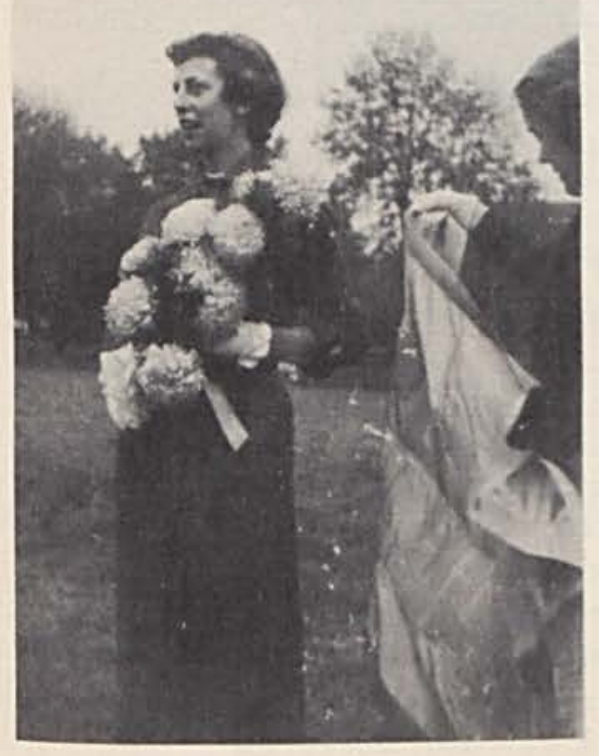

Queen

Elizabeth
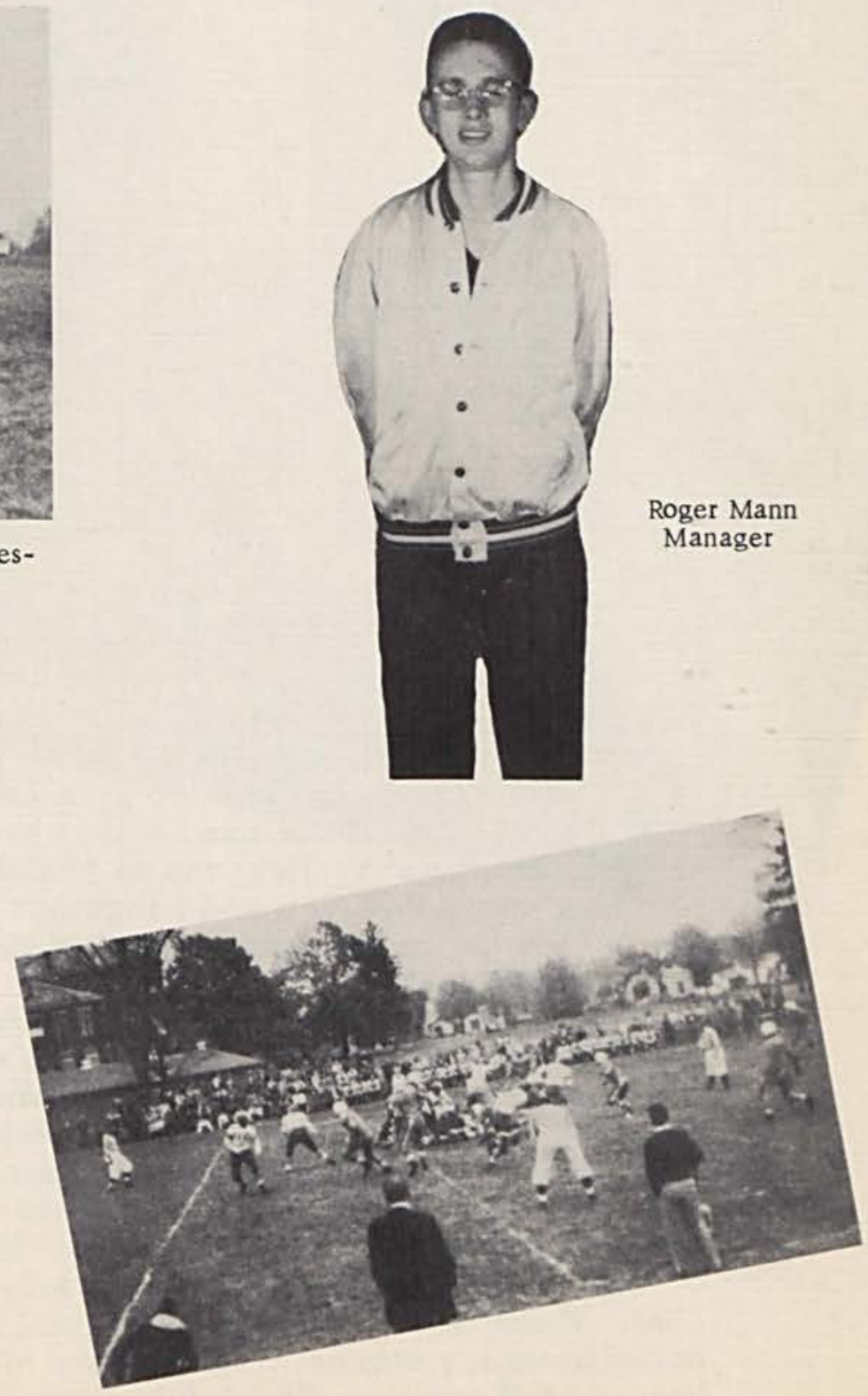



\section{BASKETBALL}

Cedarville cagers end the season with 2 wins and 15 losses. Several games were heart breakers for the boys and student body. On the whole we had a good season, having come close to winning several games. Much credit must be given Mr. Kynn and the boys, and also our seniors who will not be playing next year.

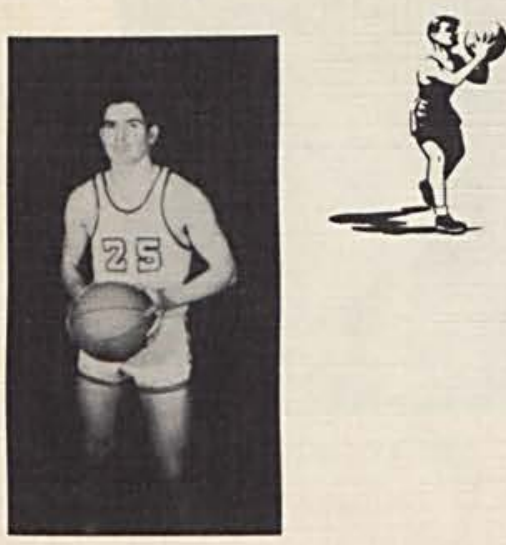

Cedarville College

Cedarville College

Cedarville College

Cedarville College

Cedarville College

Cedarville College

Cedarville College

Cedarville College

Cedarville College

Cedarville College

Cedarville College

Cedarville College

Cedarville College

Cedarville College

Earl Downs Senior

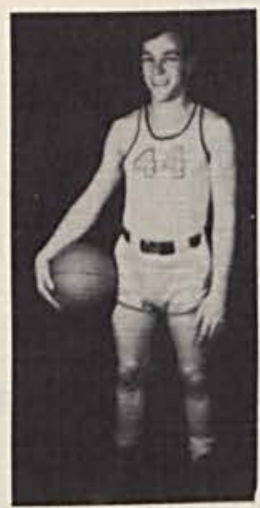

Jim Trinkle Senior
Cedarville College

Cedarville College

Cedarville College
Wilberforce University

Ohio Northern University

Ashland College

Defiance College

Wilmington College

Findlay College

Chase College

Ohio Northern University

Wilberforce University

Bluffton College

Defiance College

Bliss College

Central State

Findlay College

Ashland College

Bluffton College

Wilmington College

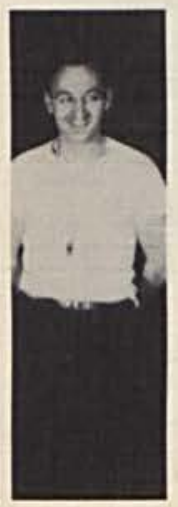

Mike Kynn coach 


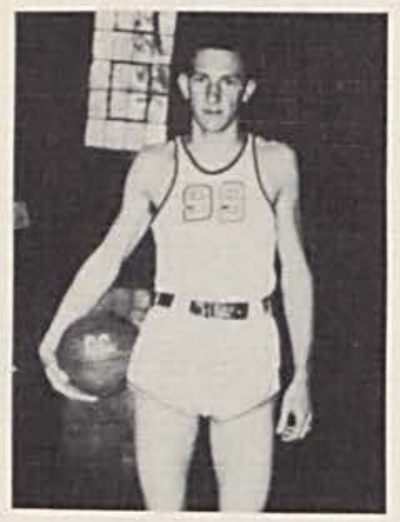

Darnell Steen

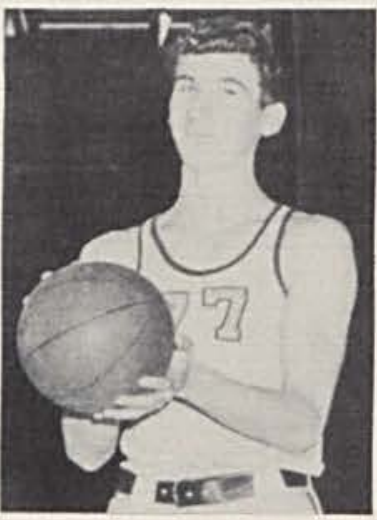

Eddie Brill

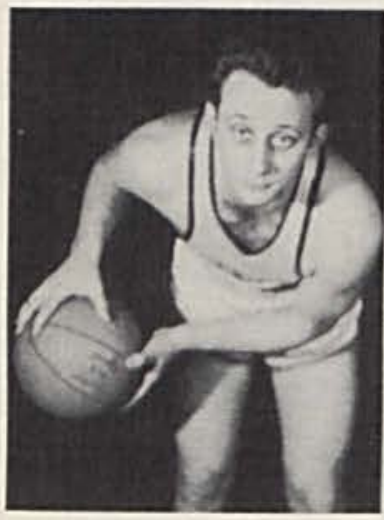

Jerry Hulshult

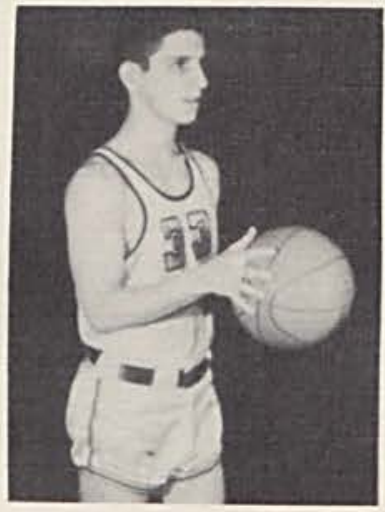

Dave Wheeler

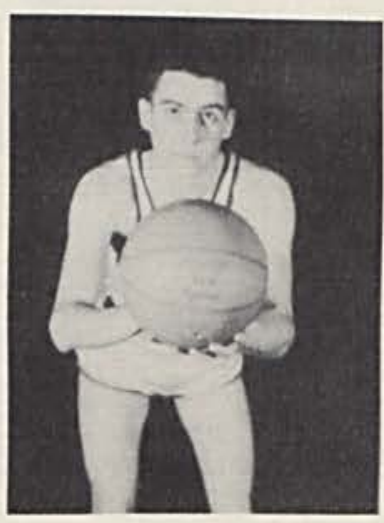

Bill Siebert 


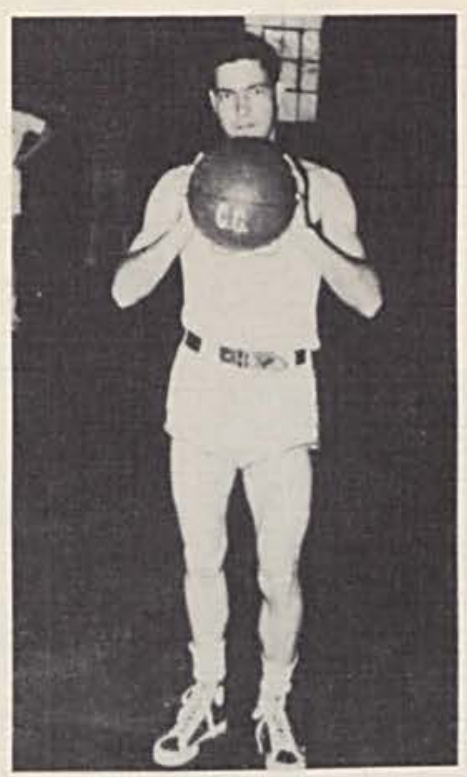

Marylin McClure

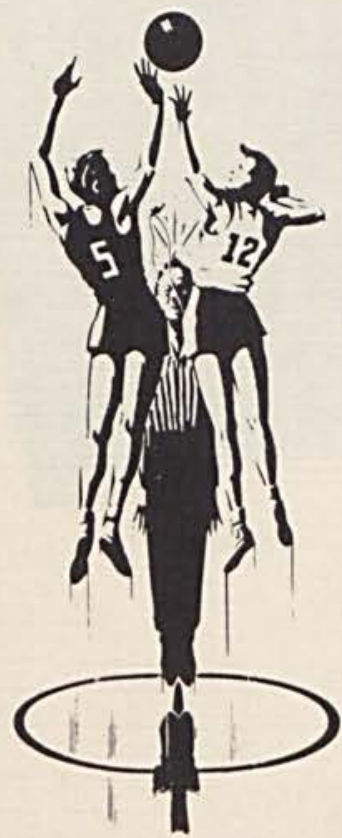

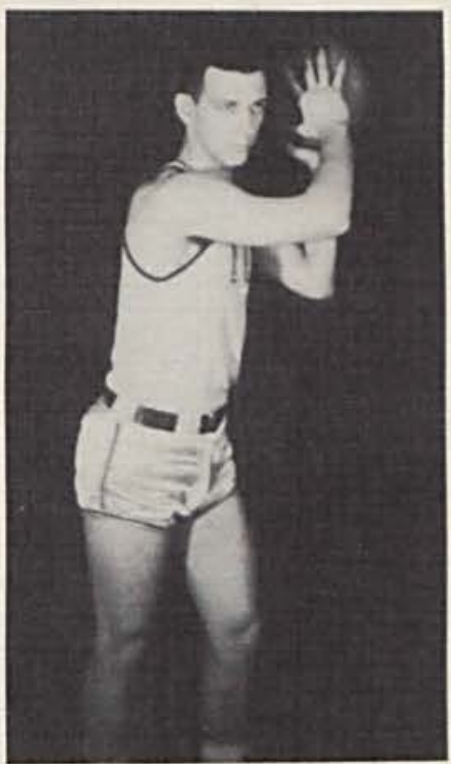

Dick Hatfield

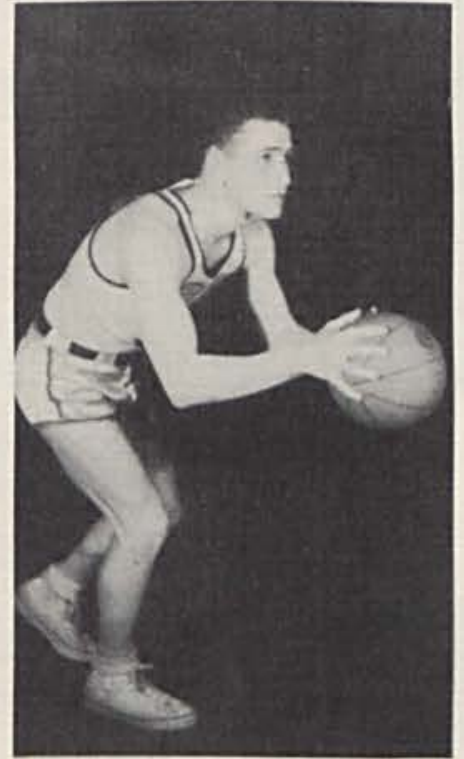

Melvin Tackett

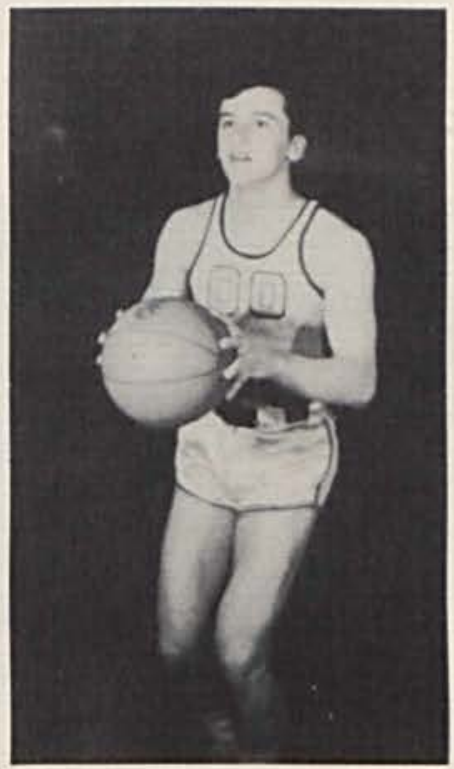

Russell Kidd 

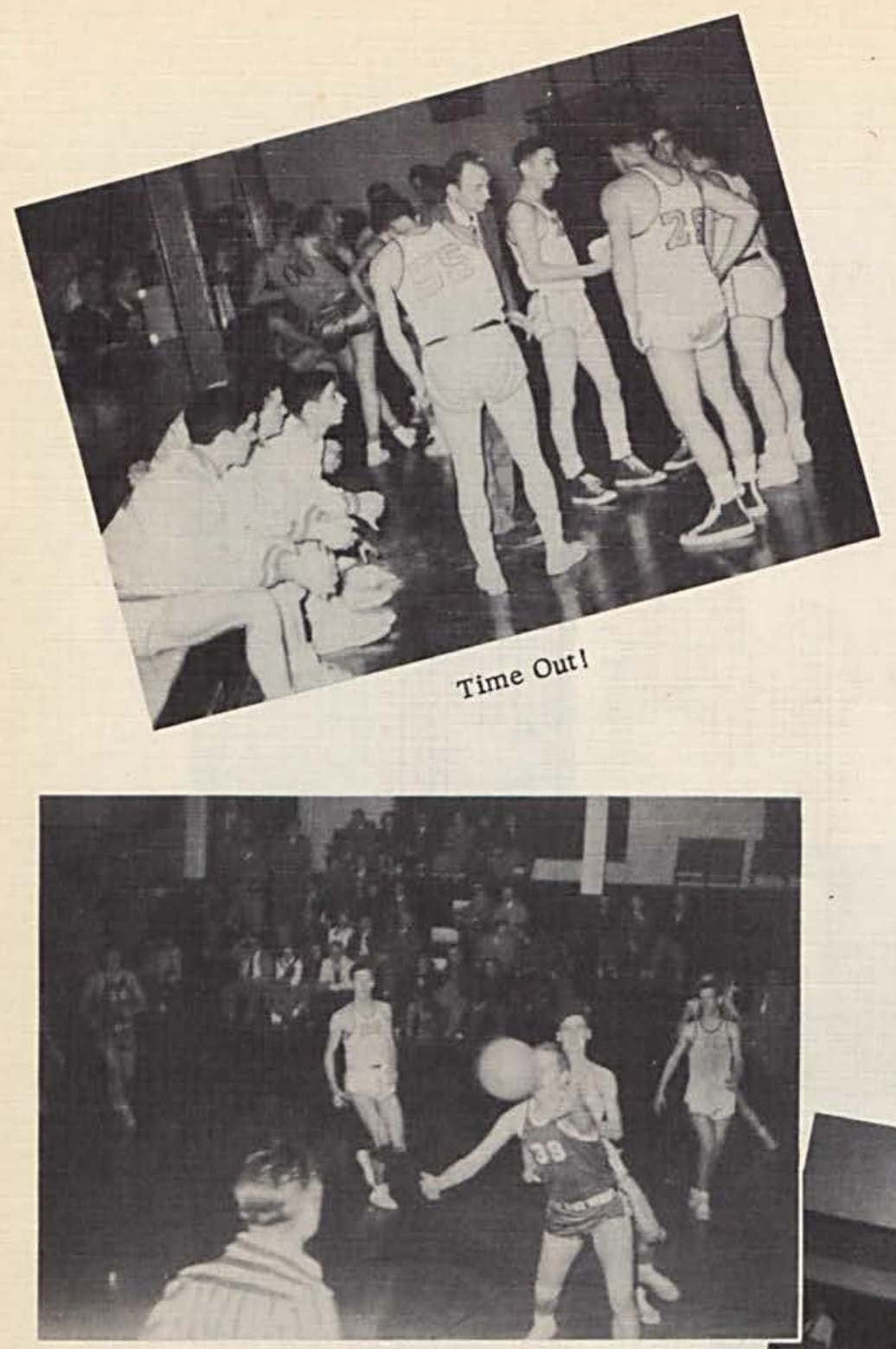

C. C. upsets Wilmington
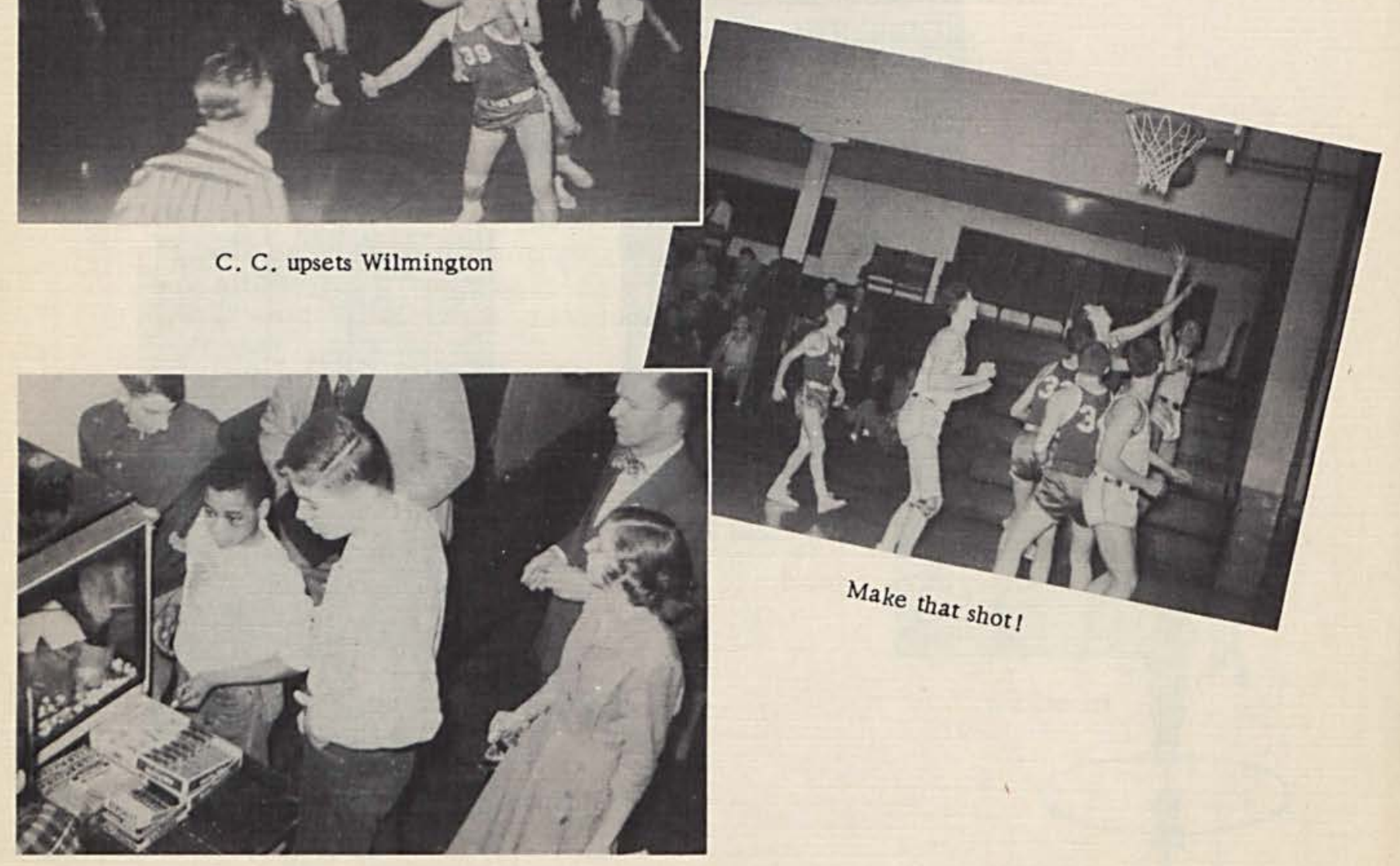

Chi Mu financial aid 


\section{The Wranglers}

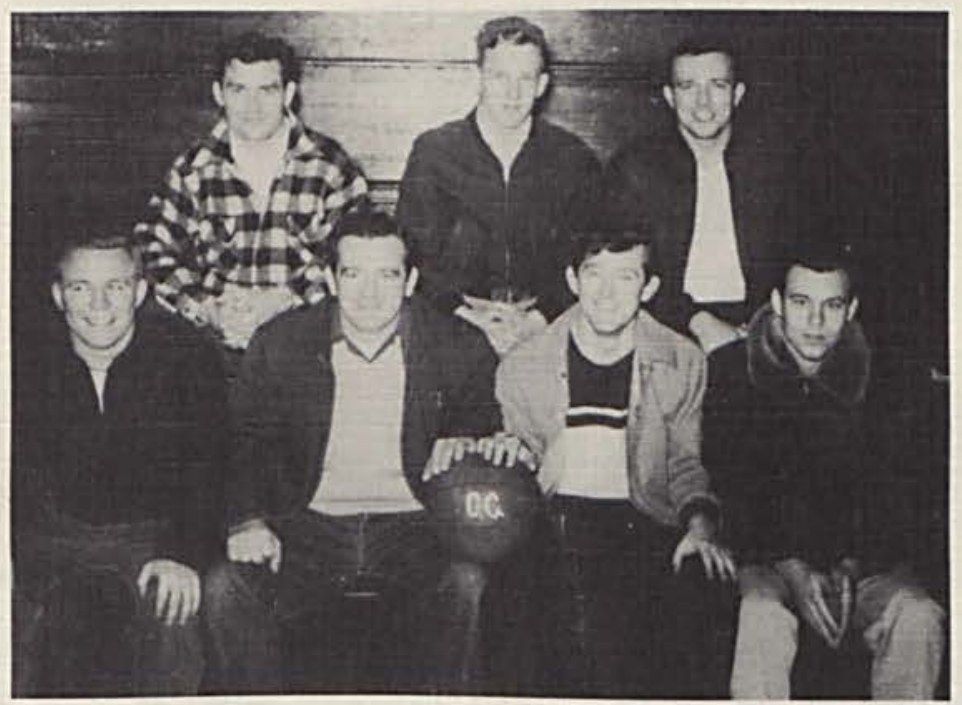

Left - Right: Bottom Row, J. Wagner, E. Kurs, D. Farmer, E. Lewis. Top Row, V. Francis, D. Staggs, J. Hartman.

For the past two seasons the Wranglers, an independent basketball team made up predominantly by members of the Chi $\mathrm{Mu}$ Delta Fraternity, have participated in practically all of the preliminary games, adding much excitement to the activities within the Alfred Memorial Gymnasium.

During the 1951-52 season, the Wranglers compiled an impressive record of seven wins and two losses. Many of these victories were at the expense of some of the strongest independent teams in this area.

Congratulations, Wranglers, on a fine season. We hope these boys will continue their fine showing of competitive spirit and sportsmanship in the years ahead. 


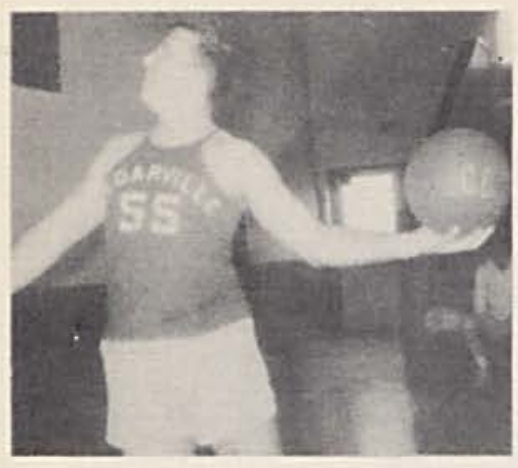

J. Hartman

Senior

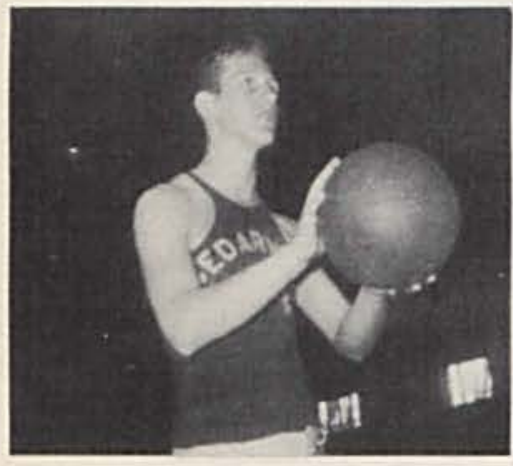

D. Staggs

Senior

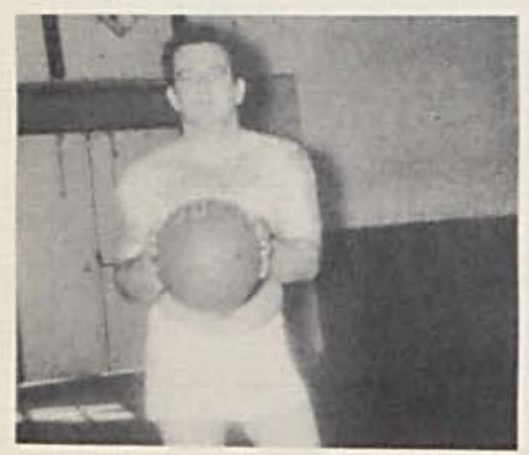

E. Kurs

Junior

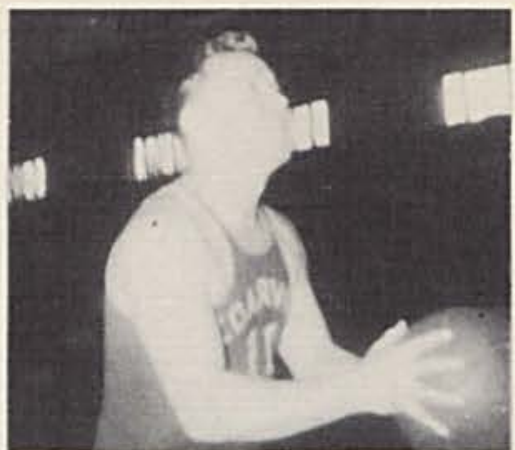

J. Wagner

Senior

RECORD

Wranglers 54 - Zenia Merchants 38

Wranglers 70 - Centerville 55

Wranglers 34 - Cedarville Col- 37 lege J. V.

Wranglers 66 - Dayton Warriors 64 (overtime)

Wranglers 47 - Cedarville High 46 Alumni

Wranglers 51 - Springfield Brew- 43 ers

Wranglers 33 - Zenia Merchants 34

Wranglers 41 - Jamestown

38

Wranglers 60 - Cedarville Col- 48 lege J. V.

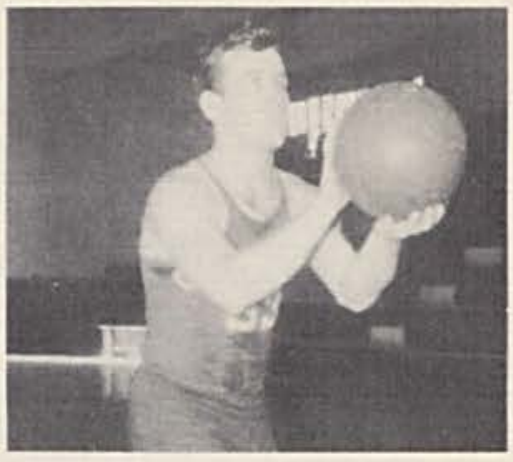

K. Carpenter Senior

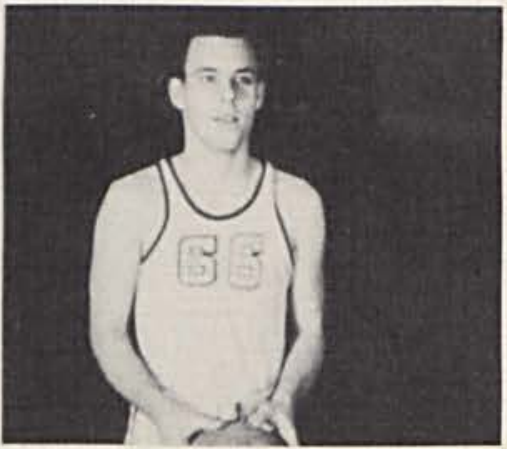

E. Lewis Sophomore

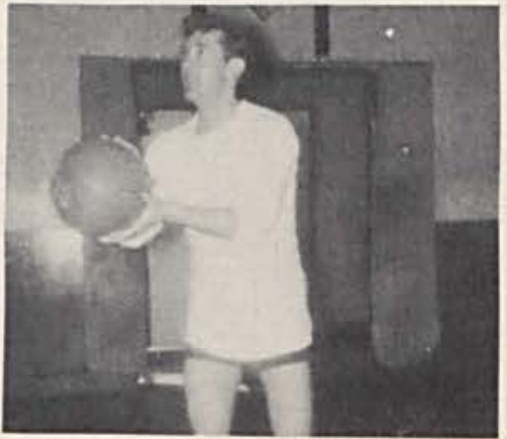

D. Farmer Sophomore 
B

A

S

E

B

I
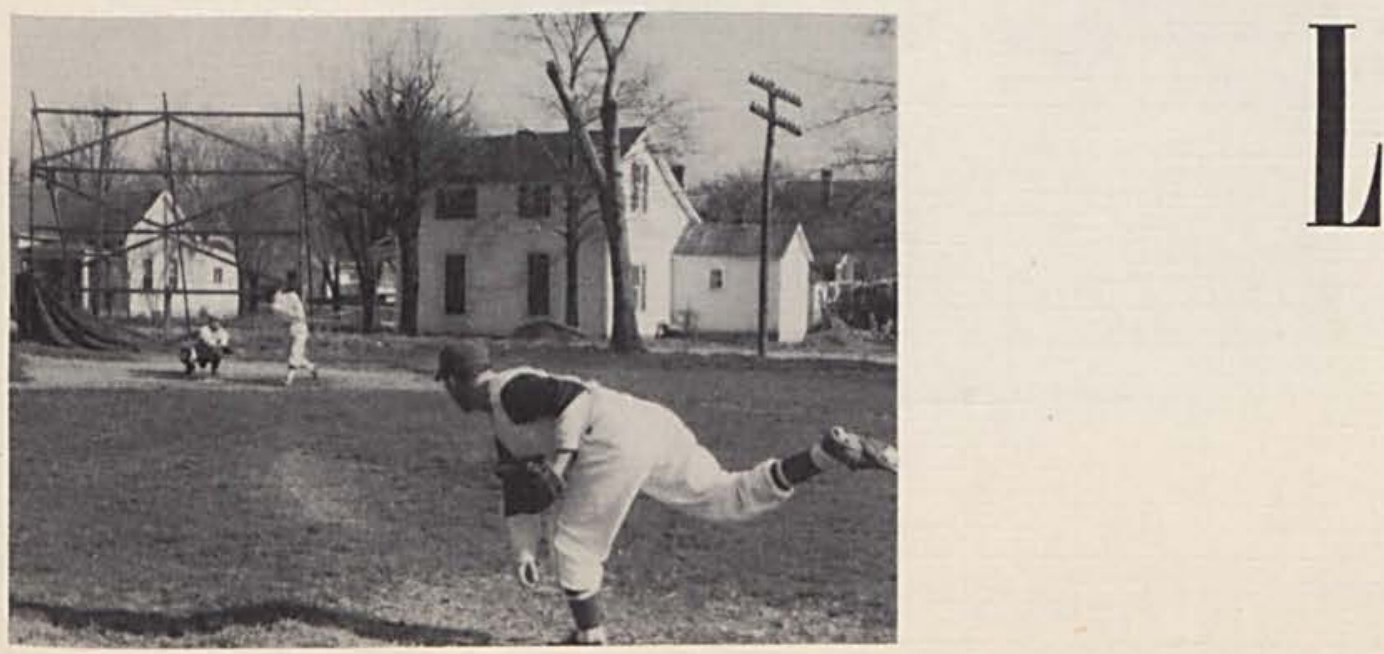


\section{MID-OHIO LEAGUE CHAMPS, '52}

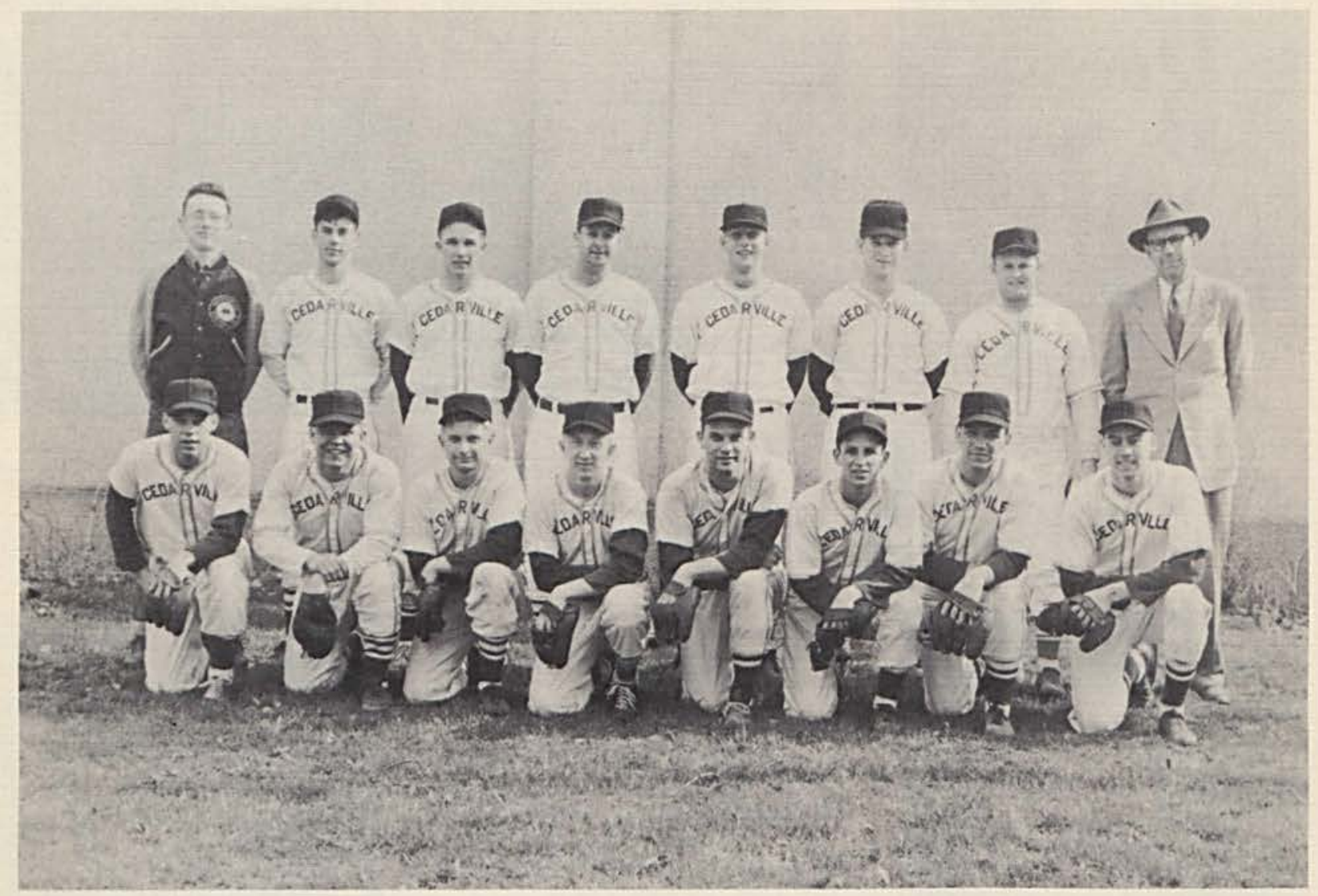

STANDING: Roger Mann, Bill Fife, Melvin Tackett, John Syrek capt. Jerry Hulshult, Wayne Joyce, Harry Schultz, E. H. Miller coach. KNEELING: Elwood Lewis, Jim Wagner, Jim Luttrell, Jim Bounds, Richard Syrek, Dave Wheeler, Jim Trinkle, Bill Seibert.

Cedarville College's hard hitting nine, came through with an 8 to 4 record taking the "MID-OHIO LEAGUE CHAMPIONSHIP". We of the college are proud of our boys and their fine record. Much credit must be given to E. H. Miller and John Syrek, who helped keep the ball rolling. This year a trophy was given to Dave Wheeler, who was chosen the most valuable player. 


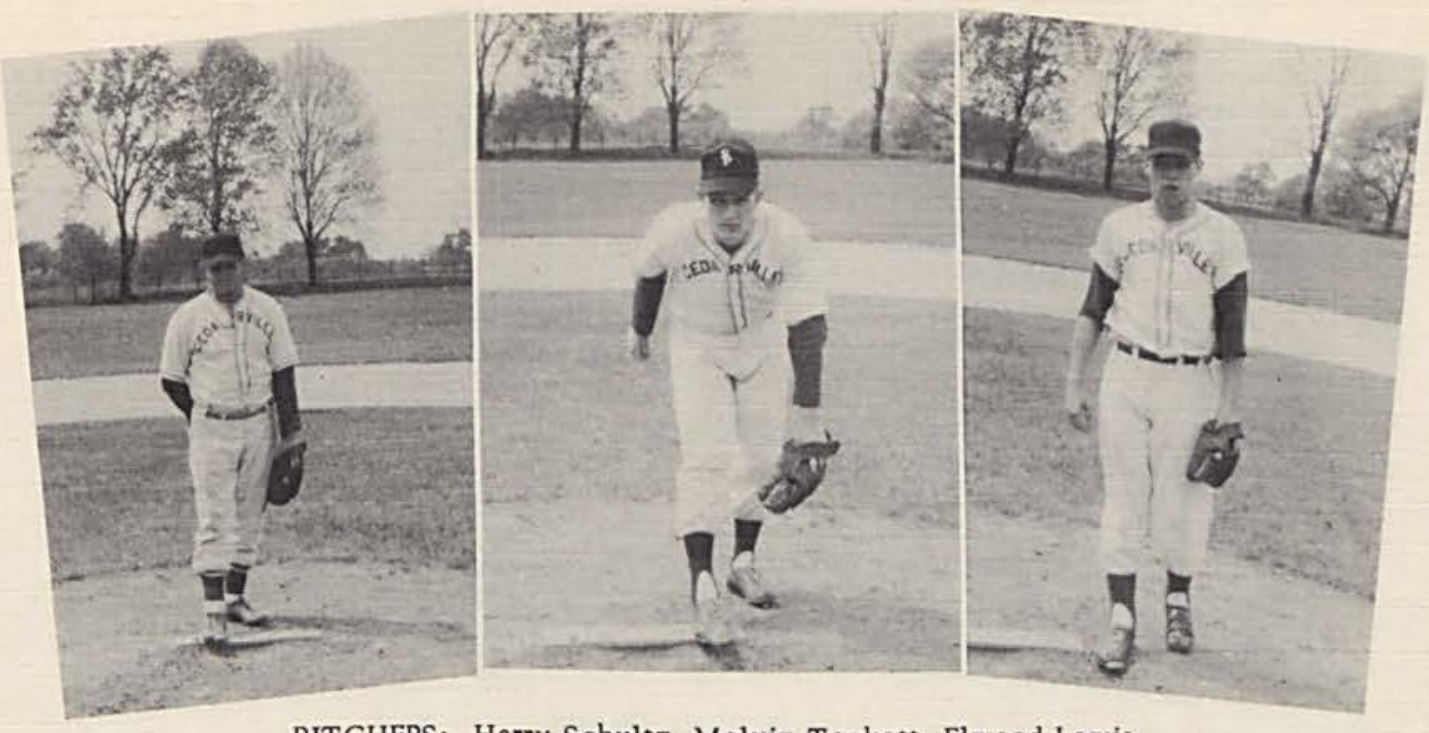

PITCHERS: Harry Schultz, Melvin Tackett, Elwood Lewis

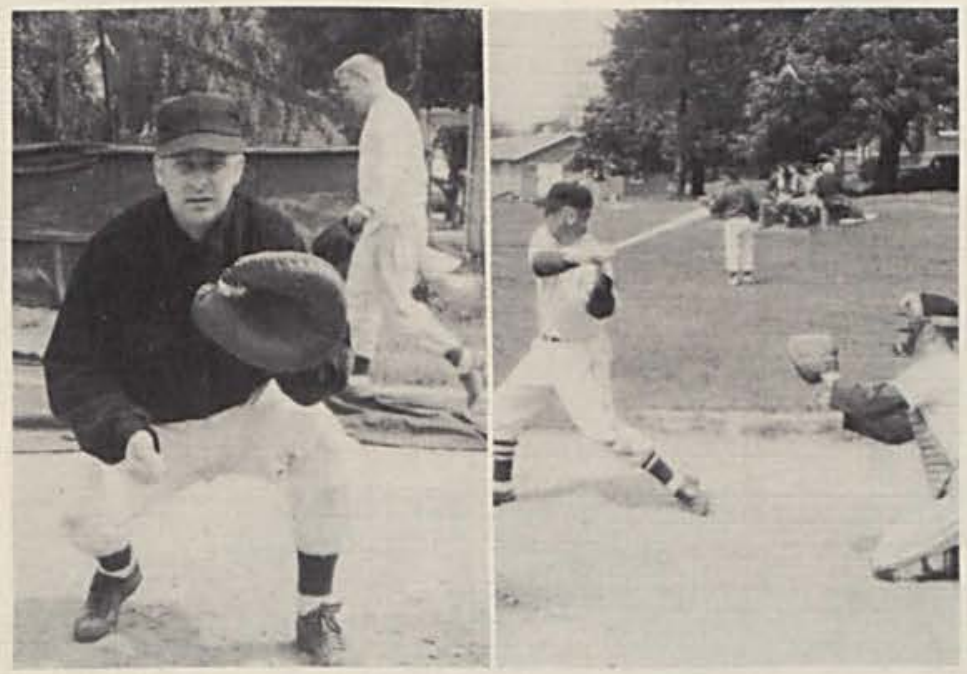

CATCHER: John Syrek and Jim Bounds 


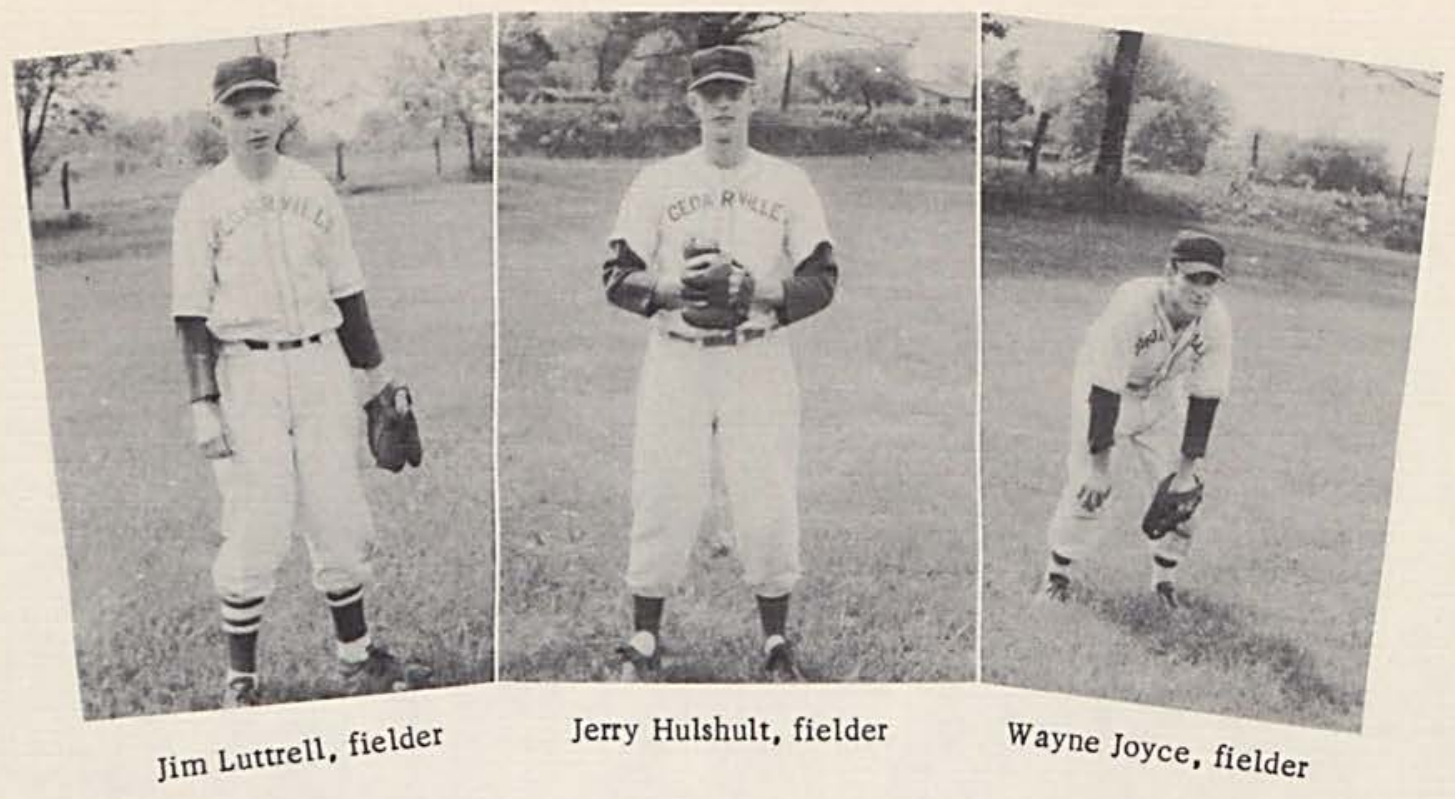

SEASON'S RECORD

Cedarville 1 Bluffton 2

Cedarville 3 University of 9

Dayton

Cedarville 7 Ashland 6

Cedarville 9 Defiance 1

Cedarville 13 Ohio Northern 3

Cedarville 7 Wright Field 3

Cedarville 6 Defiance 3

Cedarville 7 Central State 3

Cedarville 6 Wilmington 0

Cedarville 14 Bluffton 4

Cedarville 4 Central State 5

Cedarville 5 University of 6

Dayton

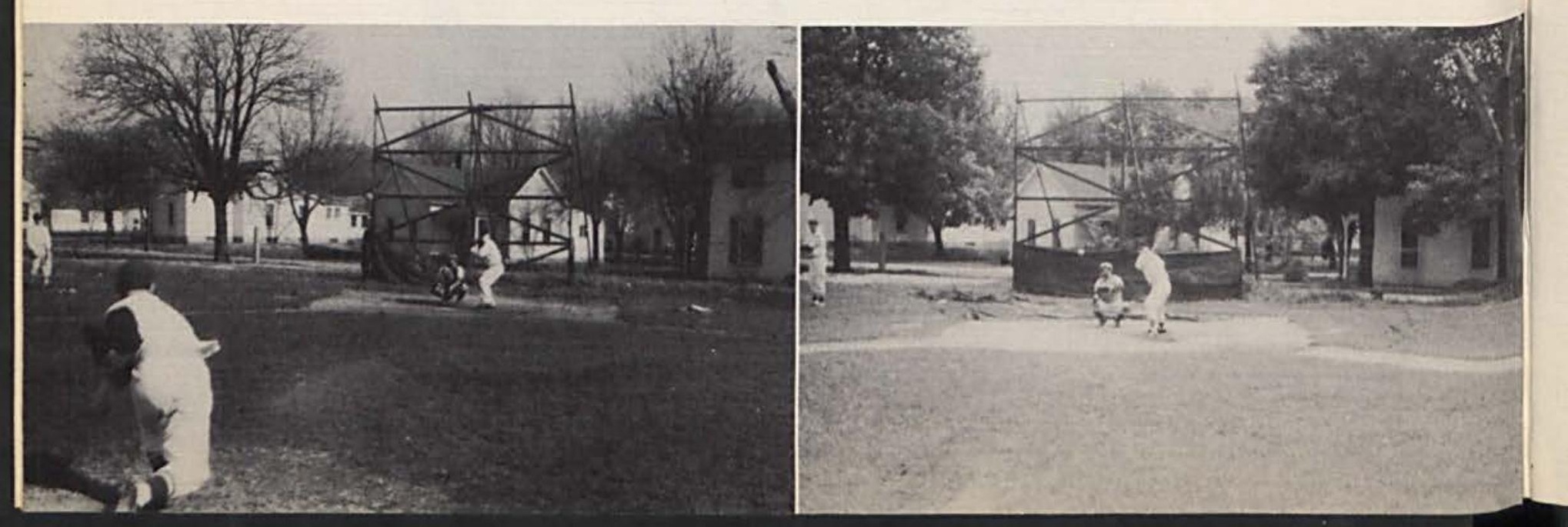



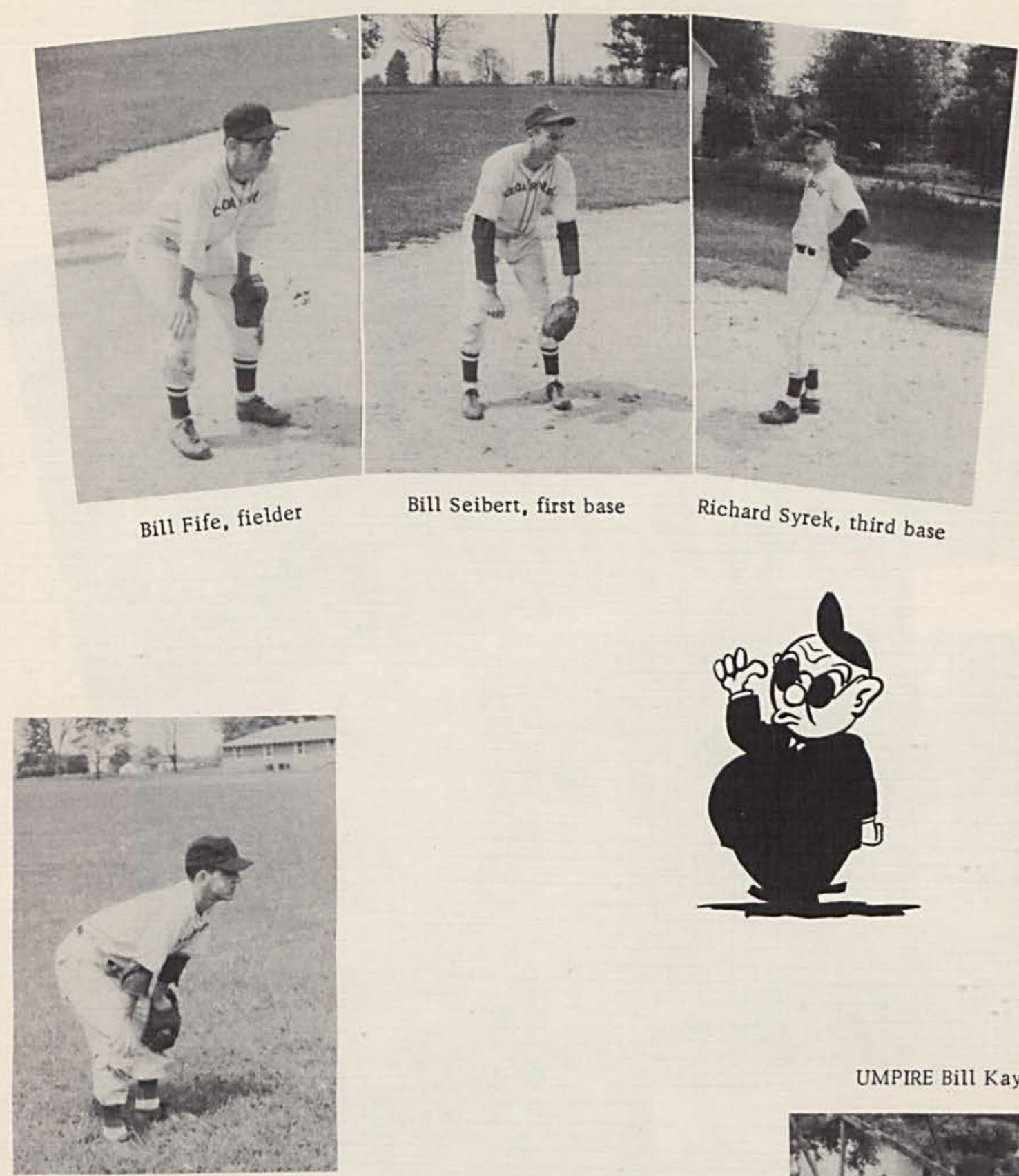

Dave Wheeler, short stop

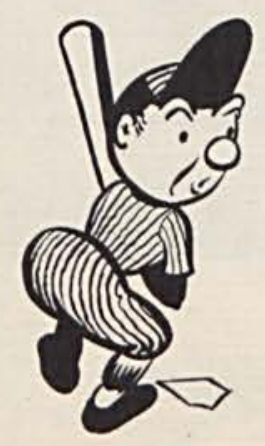

UMPIRE Bill Kaylor

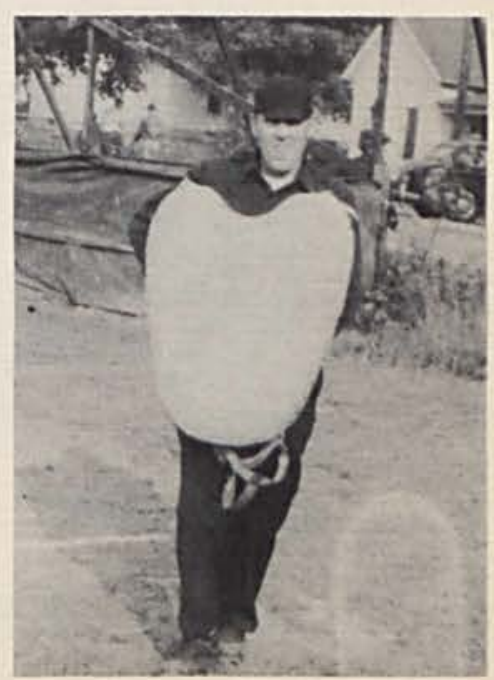




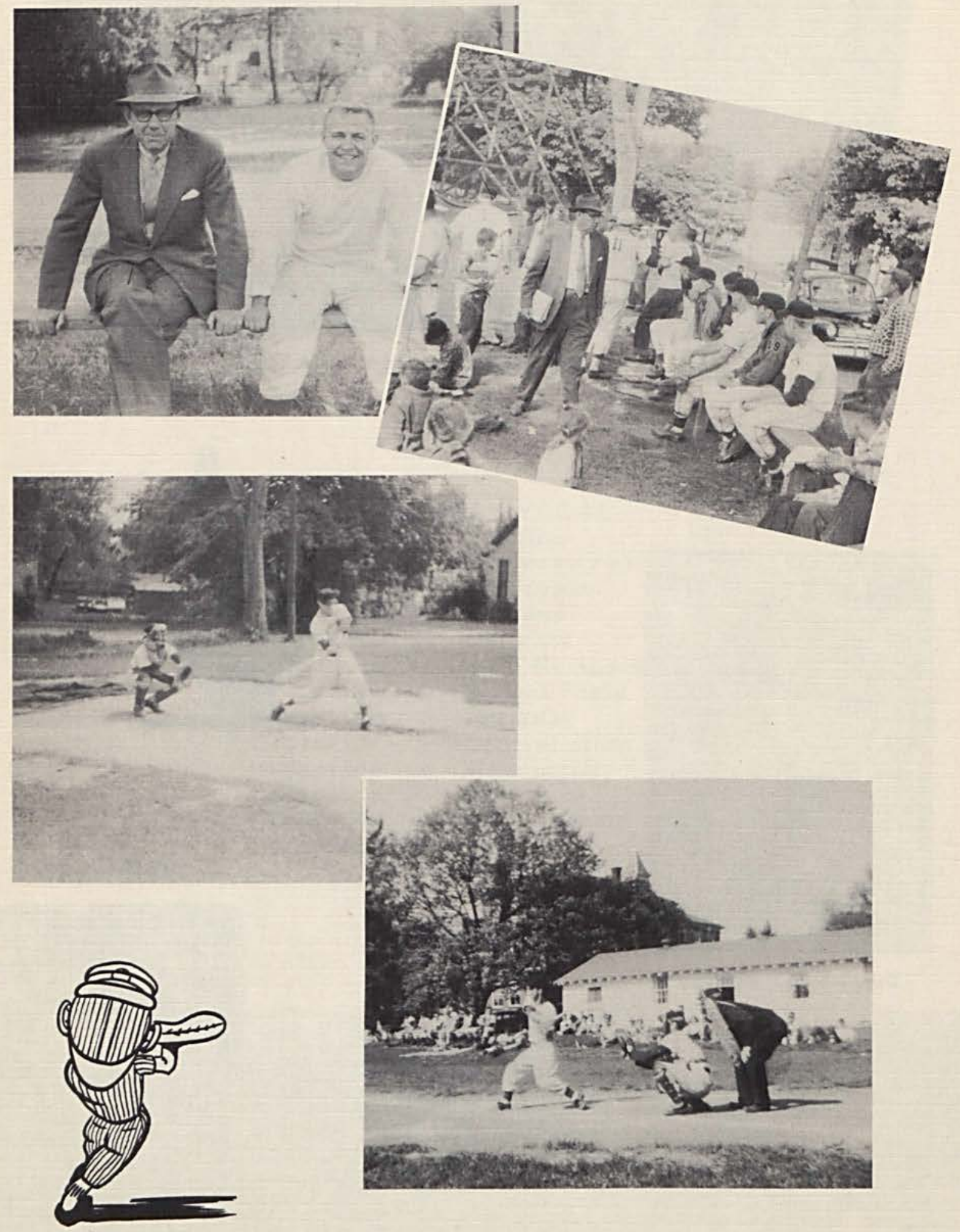



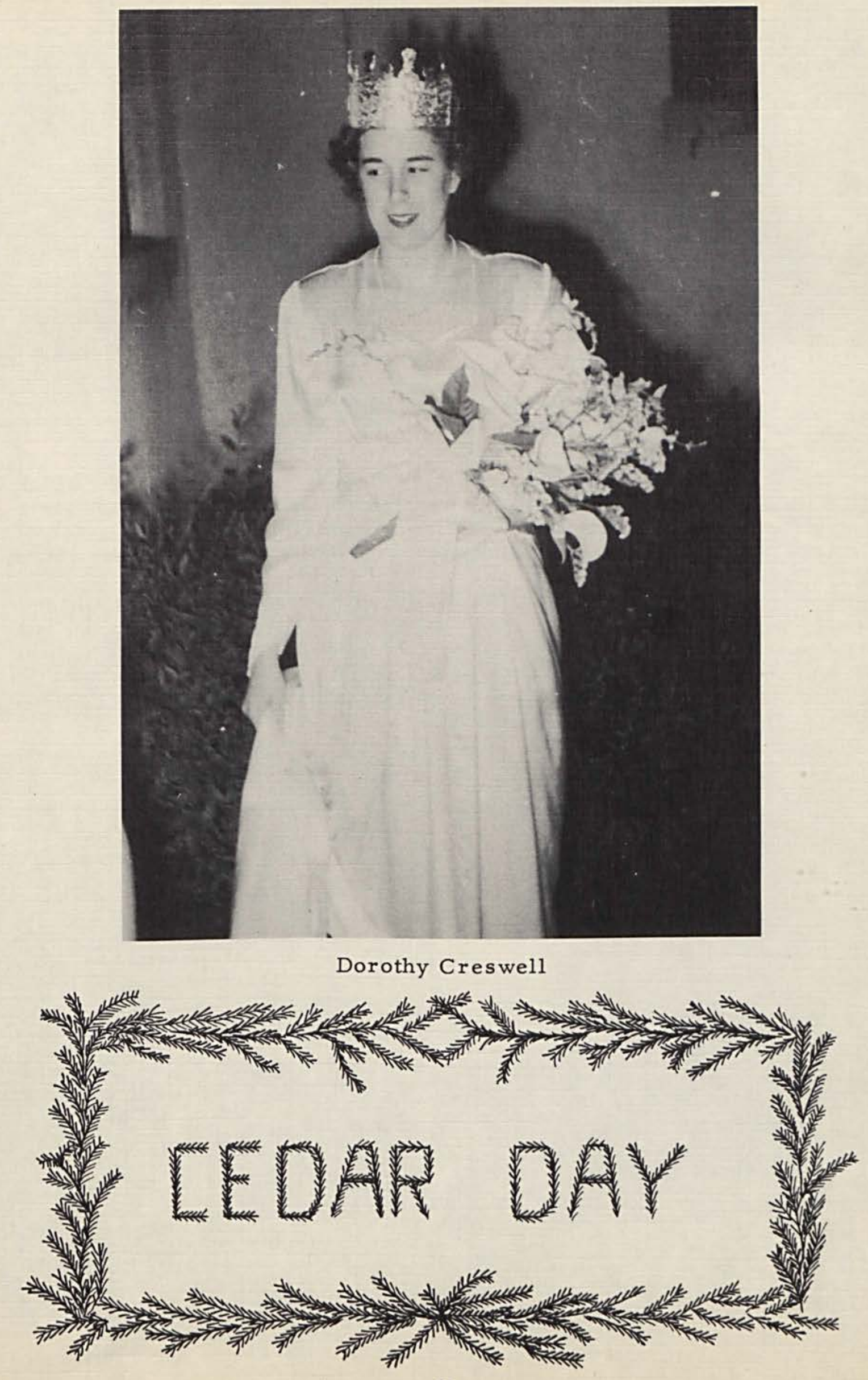


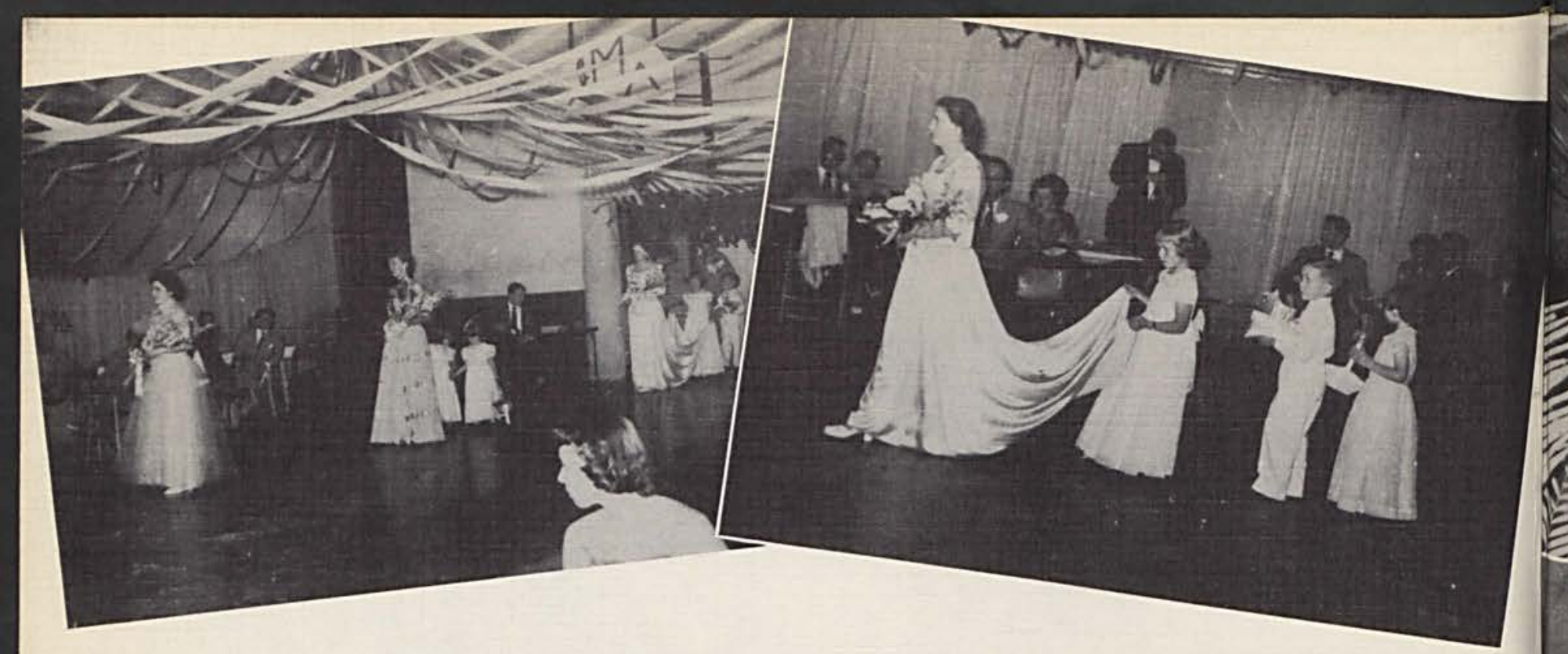

\section{PROCESSIONAL}

The activities of Cedar Day were dampened by a persistant rain, which made its appearance ten minutes before parade time. The floats took their first shower in the down-pour, while the queen's throne and the baseball diamond became so saturated that none of the afternoon activities could be held.

The crowning of the queen took place in the evening during the Chi $\mathrm{Mu}$ Delta dance. The queen was Dorothy Creswell of Cedarville. Her attendants were Elizabeth Moore of Bedford, Indiana, and Naomi McNeal of Dayton. Attending the queen, also, were Norma Jean Funderburgh, Merlin Funderburgh, Marcia Funderburgh, and Carolyn Erbaugh. The flowergirls of the attendants were Sue Huffman and Kathlene Lawson.

Norma Jean Funderburgh, Merlin Funderburgh, Carolyn Erbaugh, Marcia Funderburgh.
First row: Kathlene Lawson, Norma Jean Funderburgh, Merlin Funderburgh, Carolyn Erbaugh, Marcia Funderburgh. Second row: Naomi McNeal, Dorothy Creswell, Elizabeth Moore.
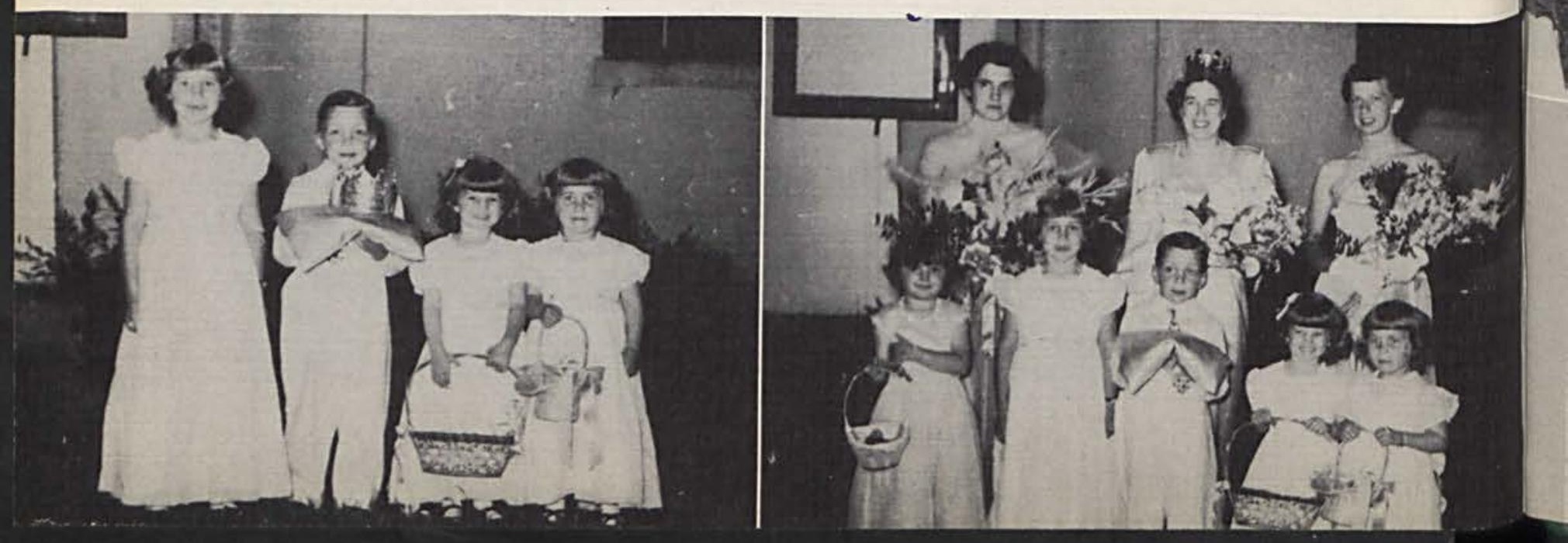


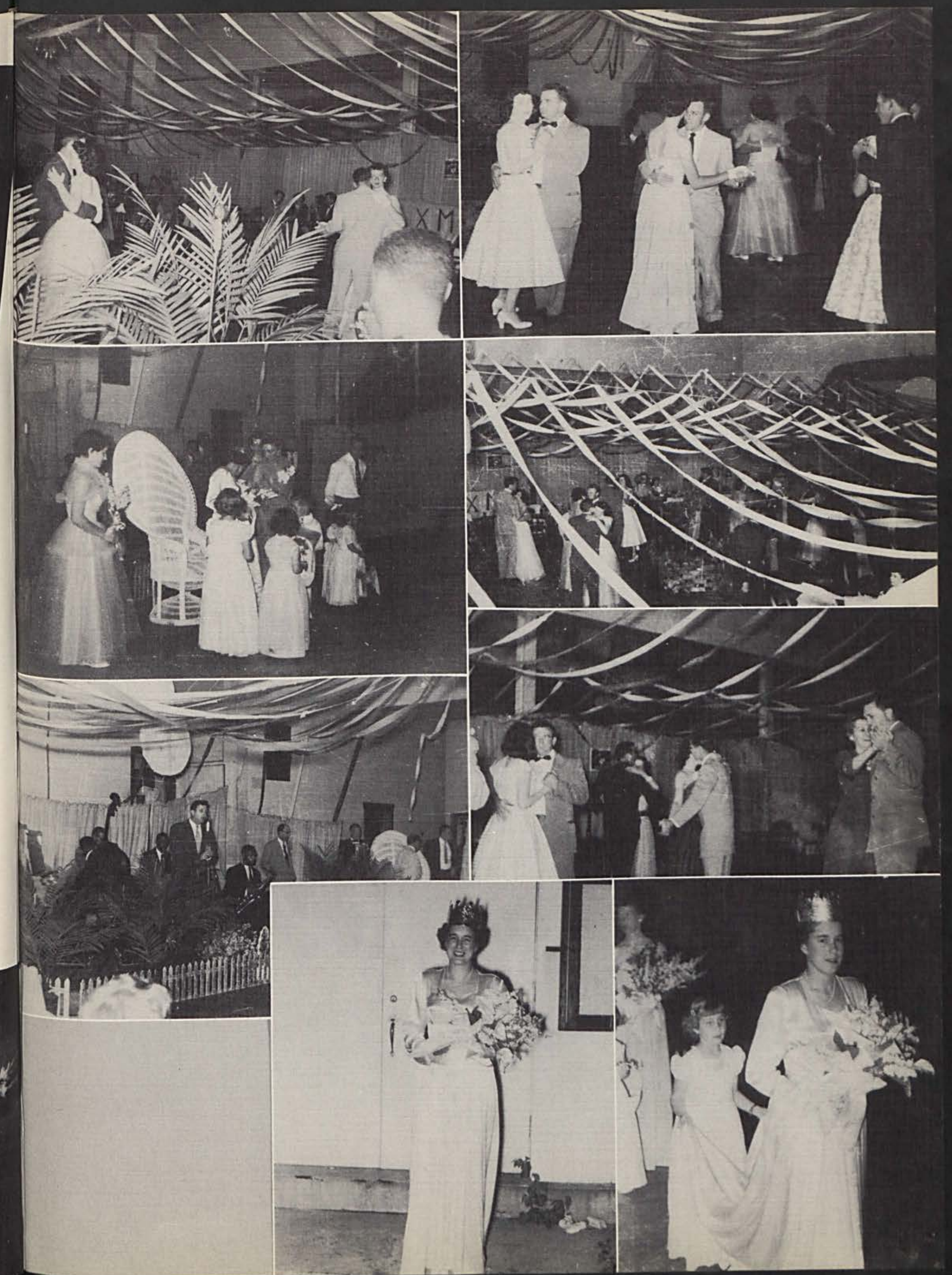




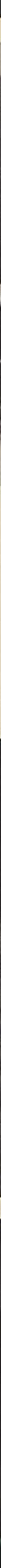




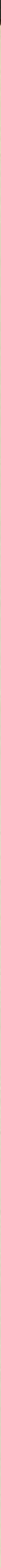

J. Hartman, J. Dill, K. Downs, B. Yeider, J. Trinkle, K. Woods, J. Syrek, J. Wagner, D. King, D. Spitzer, P. Fiedler, R. Evans, V. Hooper, G. Bauts, E. Goodwin, K. Carpenter, C. Thomas, J. English. 


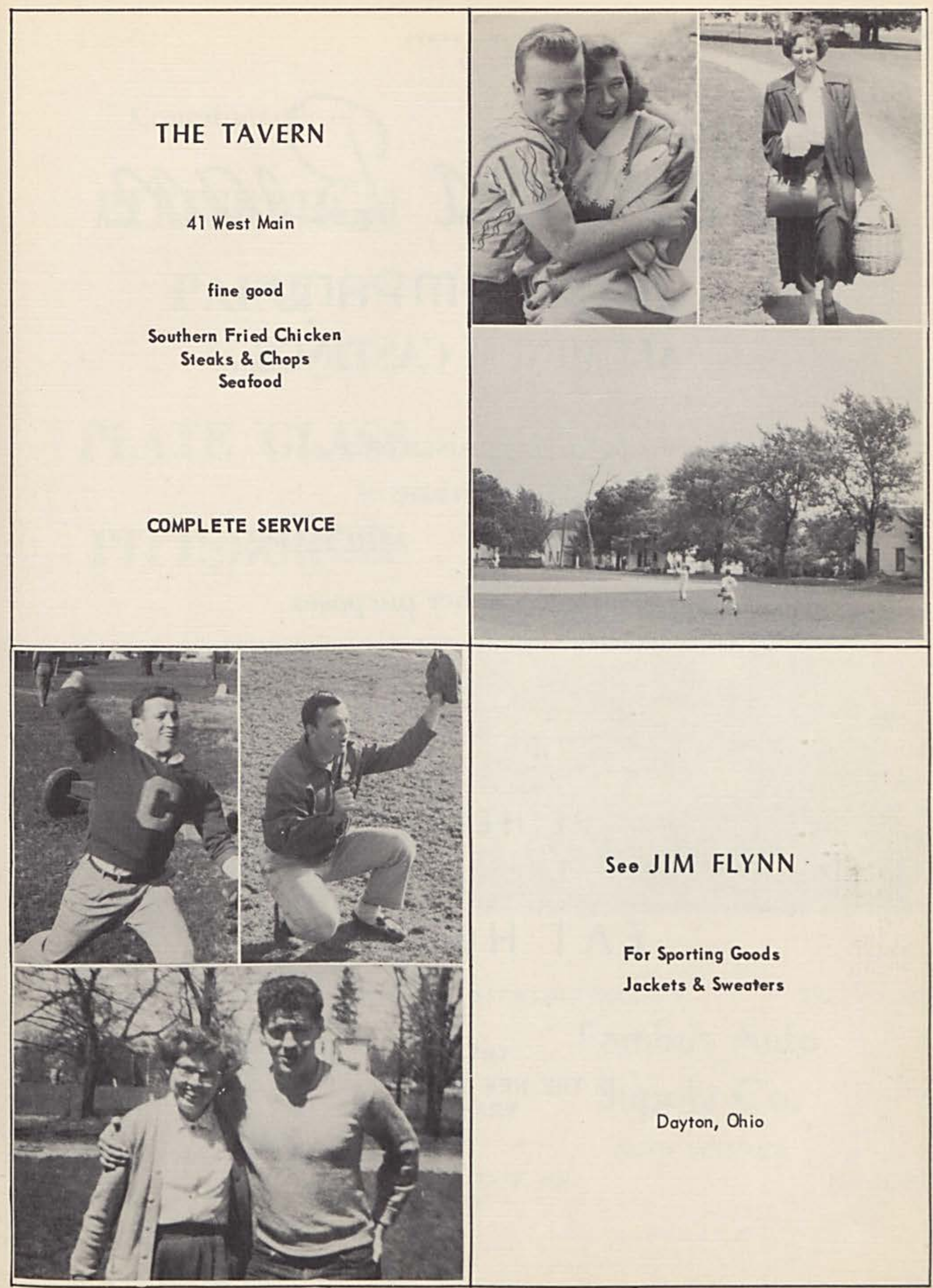


COUPLIMENTS

$O F$

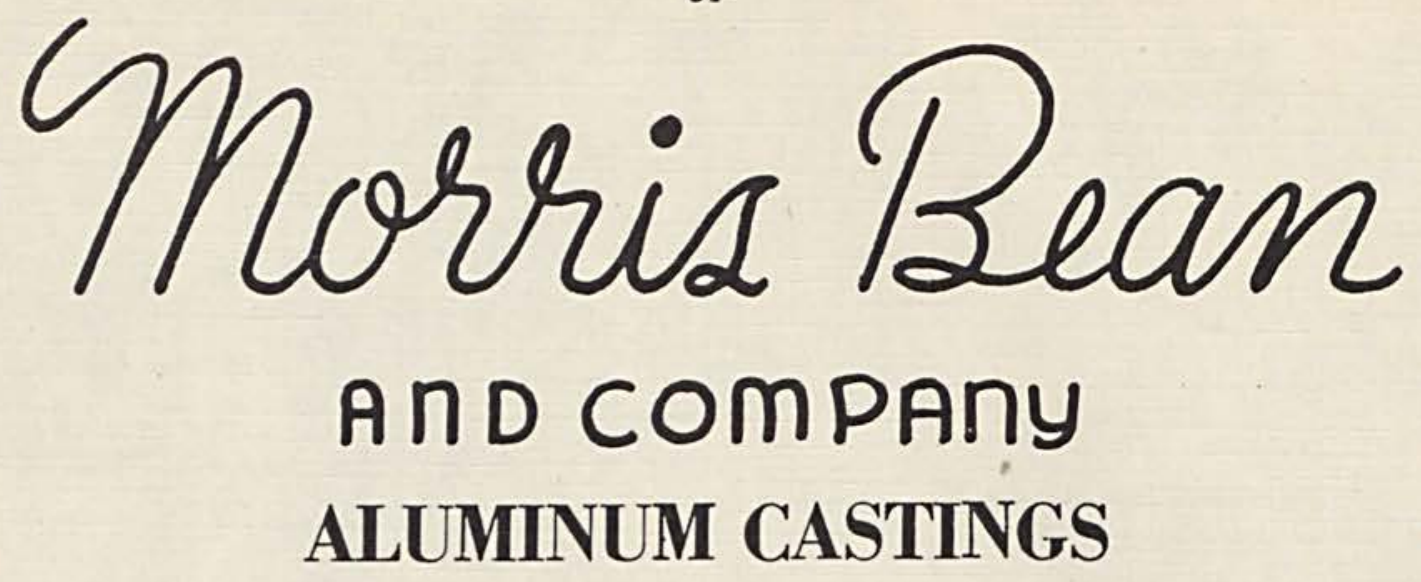

YELLOW SPRINGS, OHIO

MANUFACTURERS OF

TIREMOLDS AIRCRAFT

and many other purposes

\author{
BE HEALTHY \\ EAT HOLSUM \\ TRY IT!! \\ IN THE NEW CELLOPHANE \\ WRAPPER
}




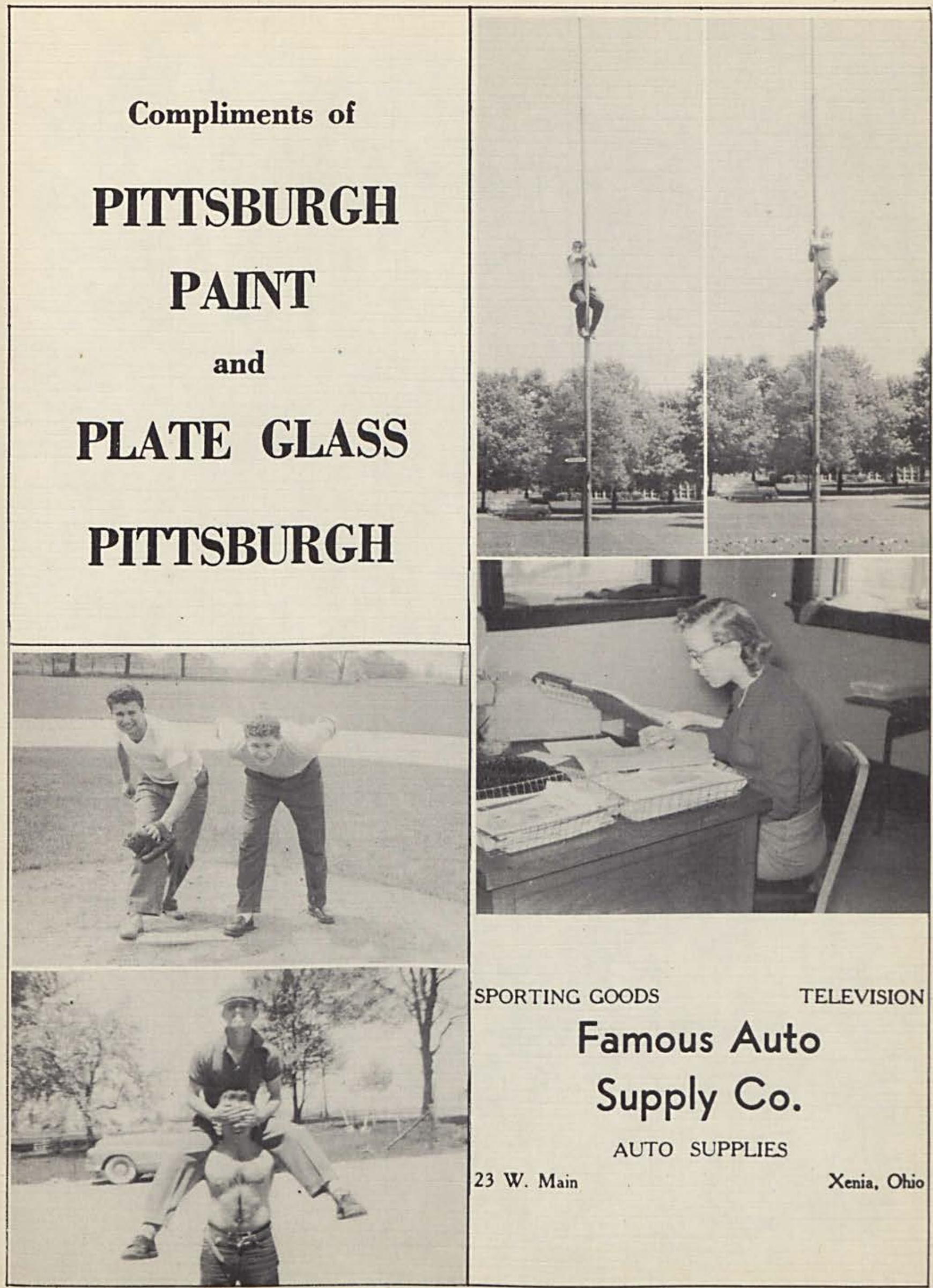




\title{
Concord Provision Company
}

\author{
Dayton, Ohio
}

- A Complete Service -

Groceries, Meats, Fresh Fruits, Vegetables \& Supplies for Hotels, Restaurants \& Institutions
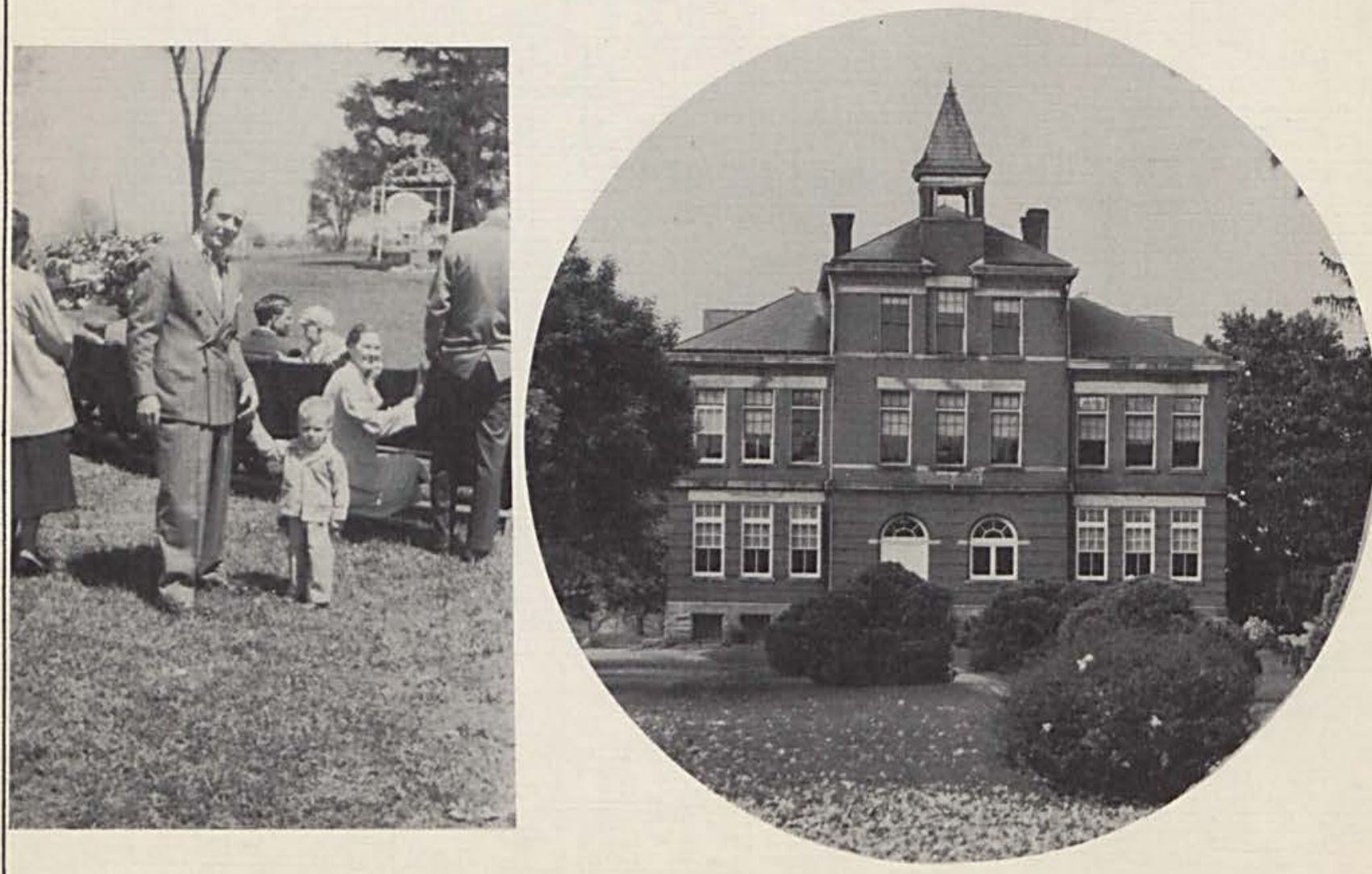


\section{ANDERSON INSURANCE AGENCY}

Competent and Complete Insurance Service

XENIA, OHIO
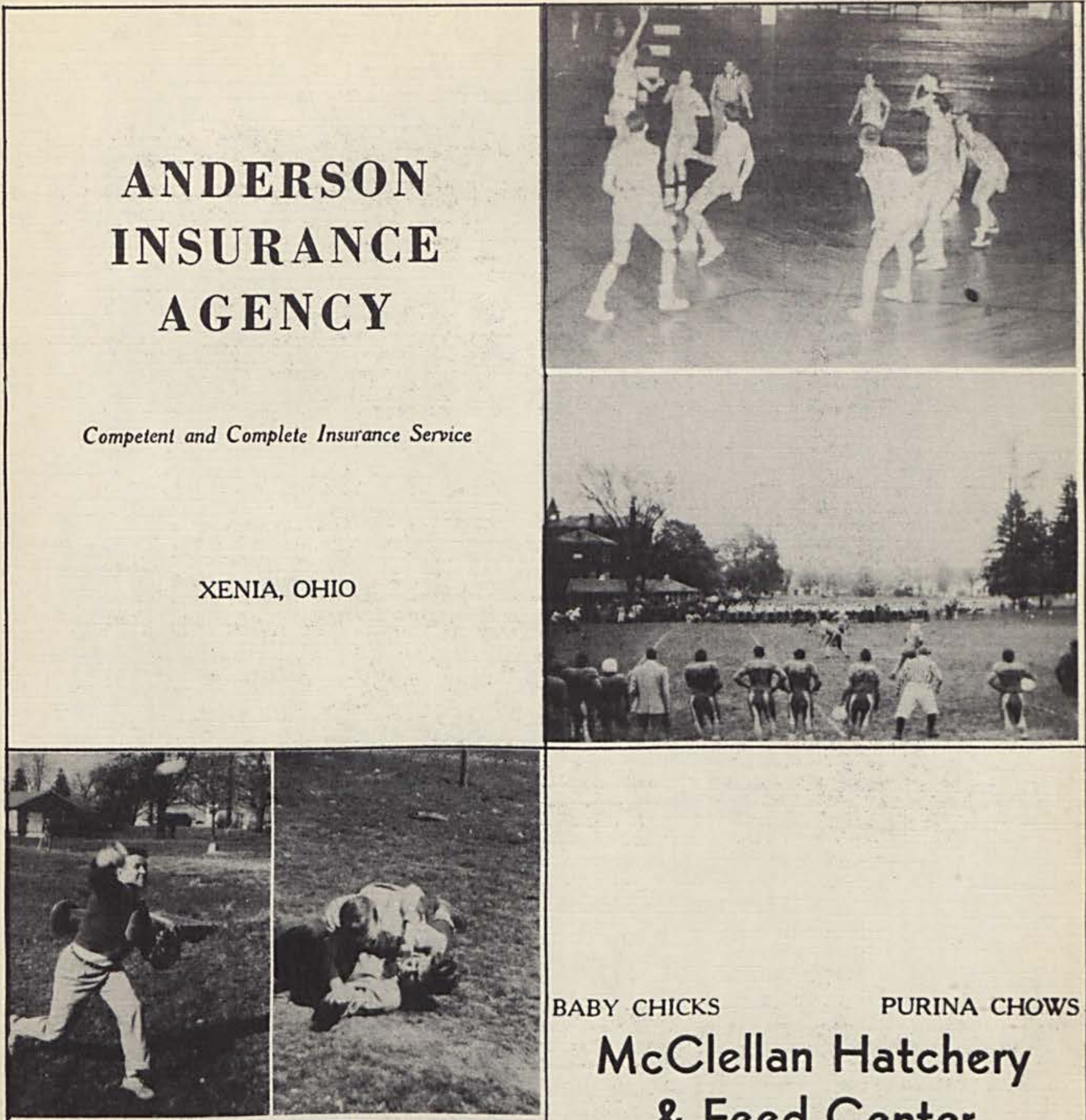

BABY CHICKS PURINA CHOWS

McClellan Hatchery \& Feed Center

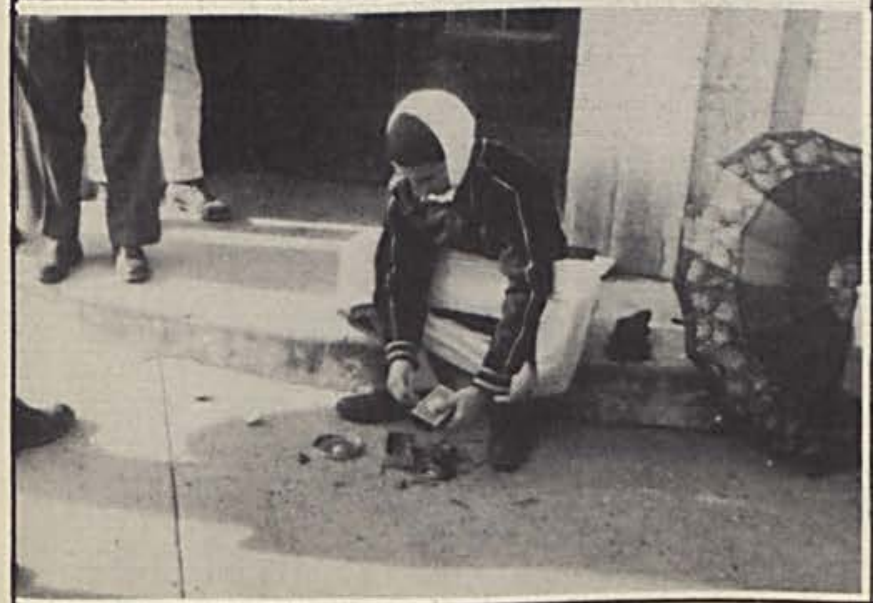

THE BEST OF CHICKS

THE BEST OF FEEDS XENIA. OHIO 


\section{XENIA NATIONAL BANK}

1835 - Over a Century of Service - 1952
CAPITAL FUNDS, $\$ 620,000$
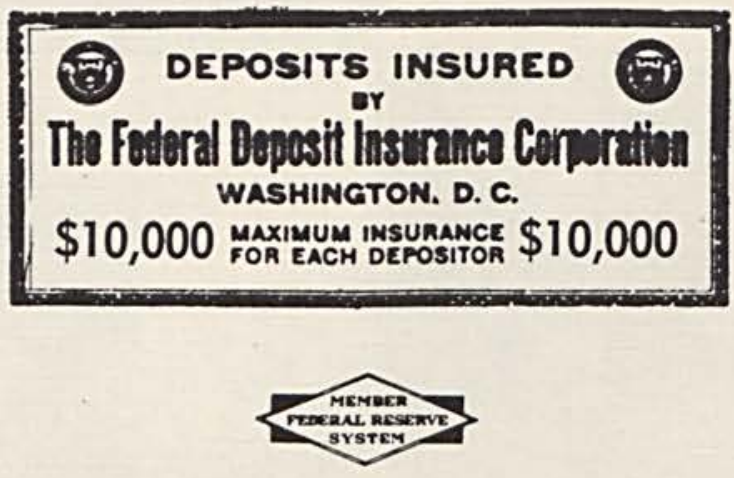

You are never a stranger after your first visit to our bank 


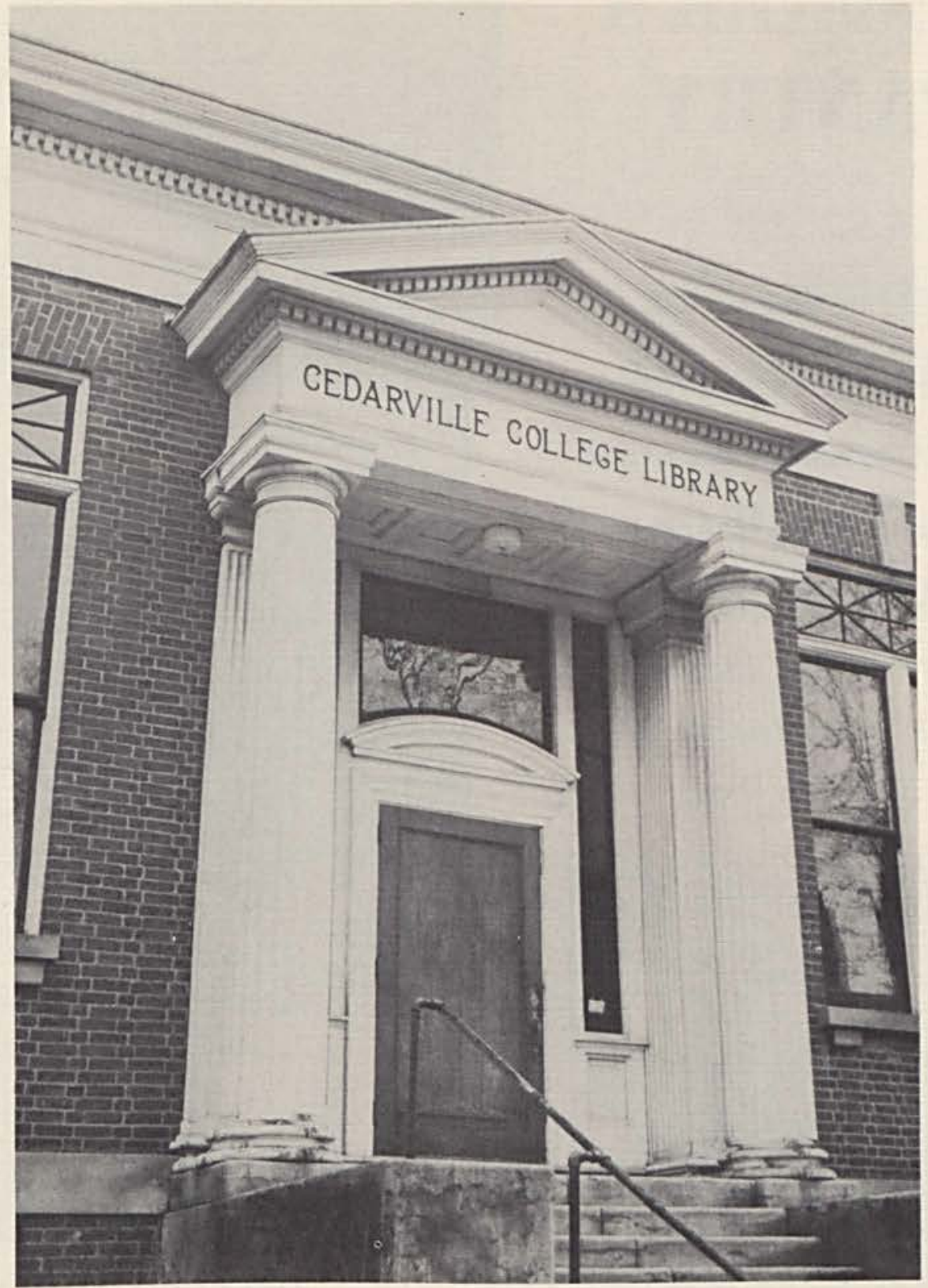

THIS PAGE SPONSORED BY

\section{THE COZY THEATER BEST OF ENTERTAINMENT}

Cedarville, Ohio 


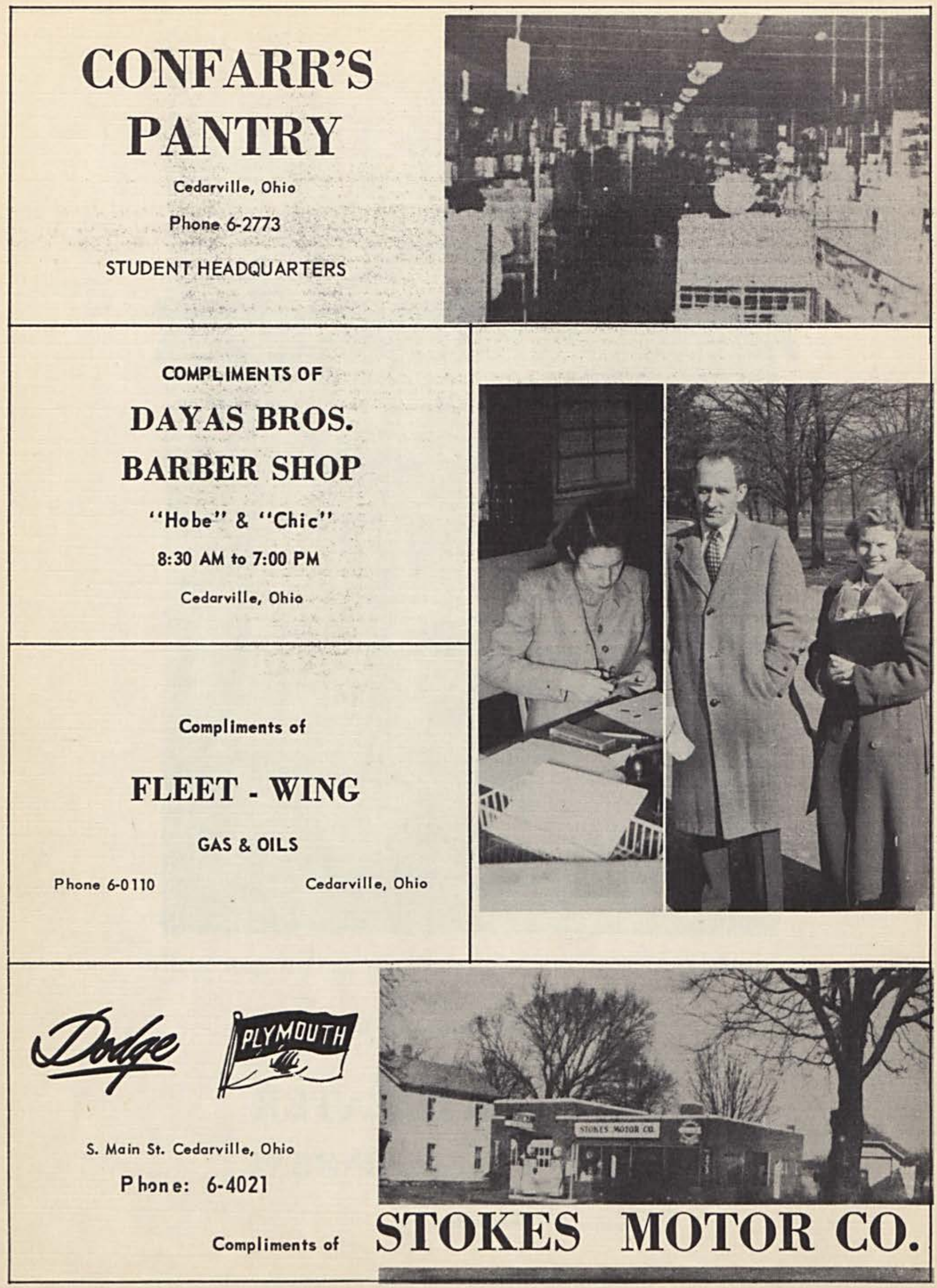




\section{JAMES DRUG CO.}

THE REXALL STORE

Phone 6-1771

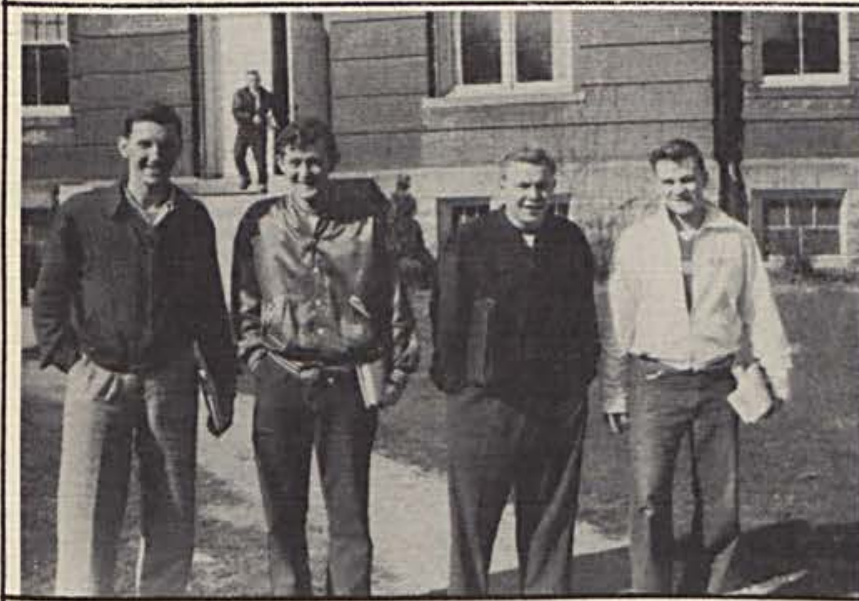

Compliments of

CEDARVILLE HARDWARE

PROGRESSIVE HARDWARE SERVICE

CEDARVILLE, OHIO

PHONE: 6-1941

\section{Compliments of \\ CEDARVILLE FEED \& GRAIN}

CEDARVILLE, OHIO

Phone: 6-2021

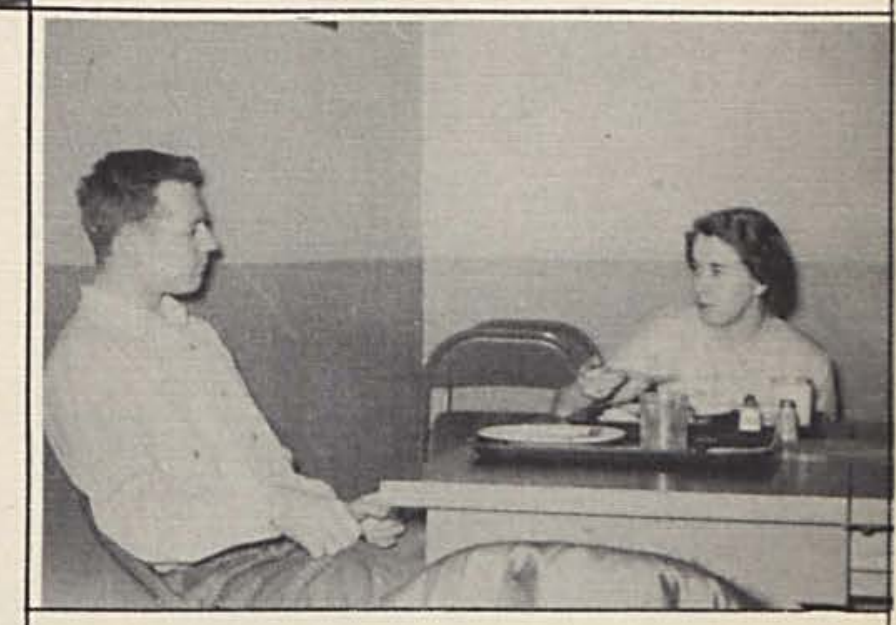

\section{PICKERING ELECTRIC} CONTRACTOR and DEALER

WESTINGHOUSE APPLIANCES SUNBEAM APPLIANCES

EASY WASHERS HOOVER CLEANERS

Cedarville, Ohio 


\section{CONGRATULATIONS}

Managing a small college is no eas job in this day of inflation costs and war pressures. We congratulate the trustees and officers of Cedarville College for keeping up such high scholastic standards in spite of economic pressures which have been particularly strong on small colleges.

We believe that the tradition and past accomplishments of sending out more than your share of students to become illustrous citizens will continue.

The Miami Deposit Bank

Yellow Springs and Cedarville, Ohio Member F. D. I. C.
Compliments Of

HILLTOP MARKET

Meats and Groceries

Phone: 6-2151

Cedarville, Ohio

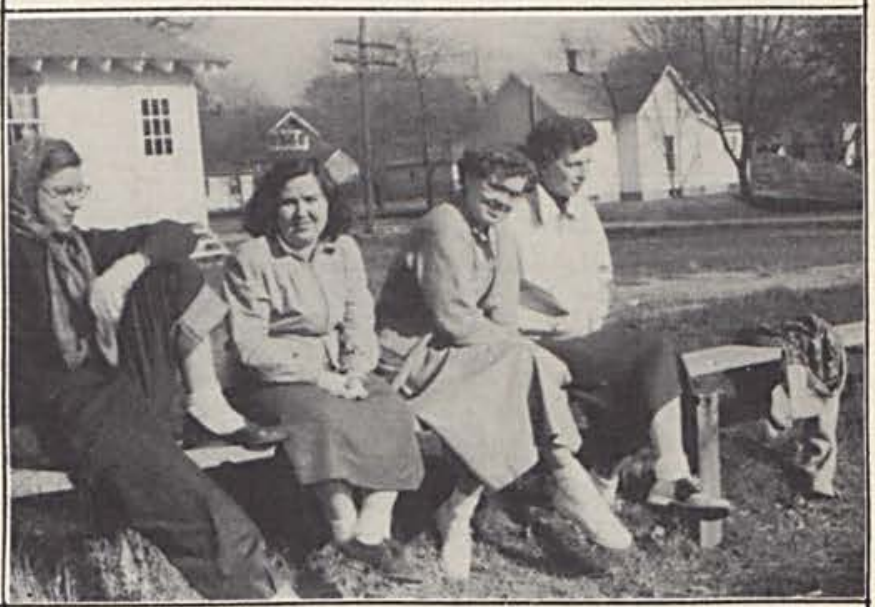

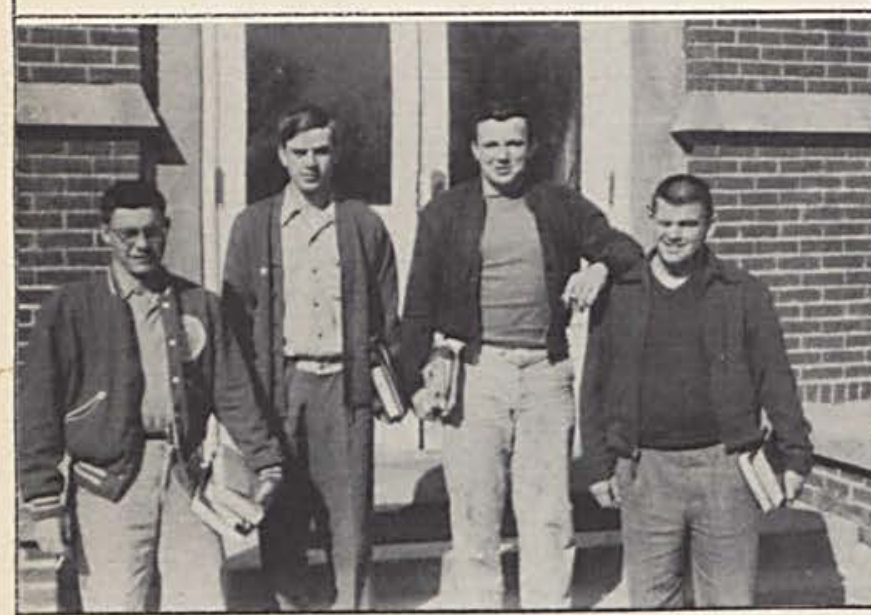

Compliments of

THE

CEDARVILLE

HER A L D

Cedarville's Oldest Institution

Phone: 6-1711 $\star$ Films

* Cameras

* Darkroom Supplies

COMMERCIAL \& PORTRAIT PHOTOGRAPHY

Creswell Camera Store

XENIA AVENUE CEDARVILLE, OHIO

Phone: 6-3311 
Compliments of

HILLTOP SERVICE STATION

Cedarville, Ohio

Sunoco Gas and Oils

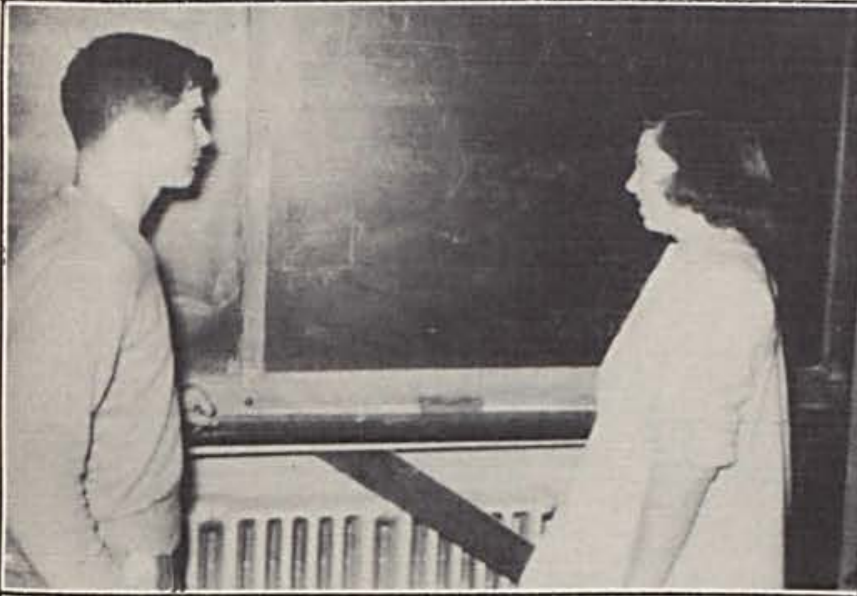

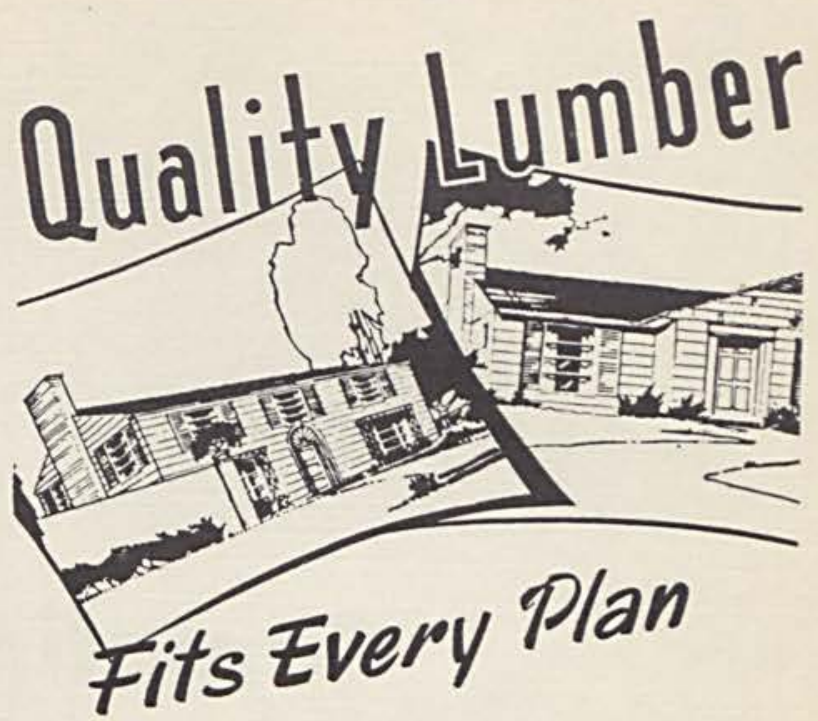

CEDARVILLE LUMBER CO.

"Dedicated to Serve"

6-1331 CEDARVILLE, OHIO

Compliments of

HAMMAN'S

DAIRY

Cedarville, Ohio

We Sell Borden's Milk

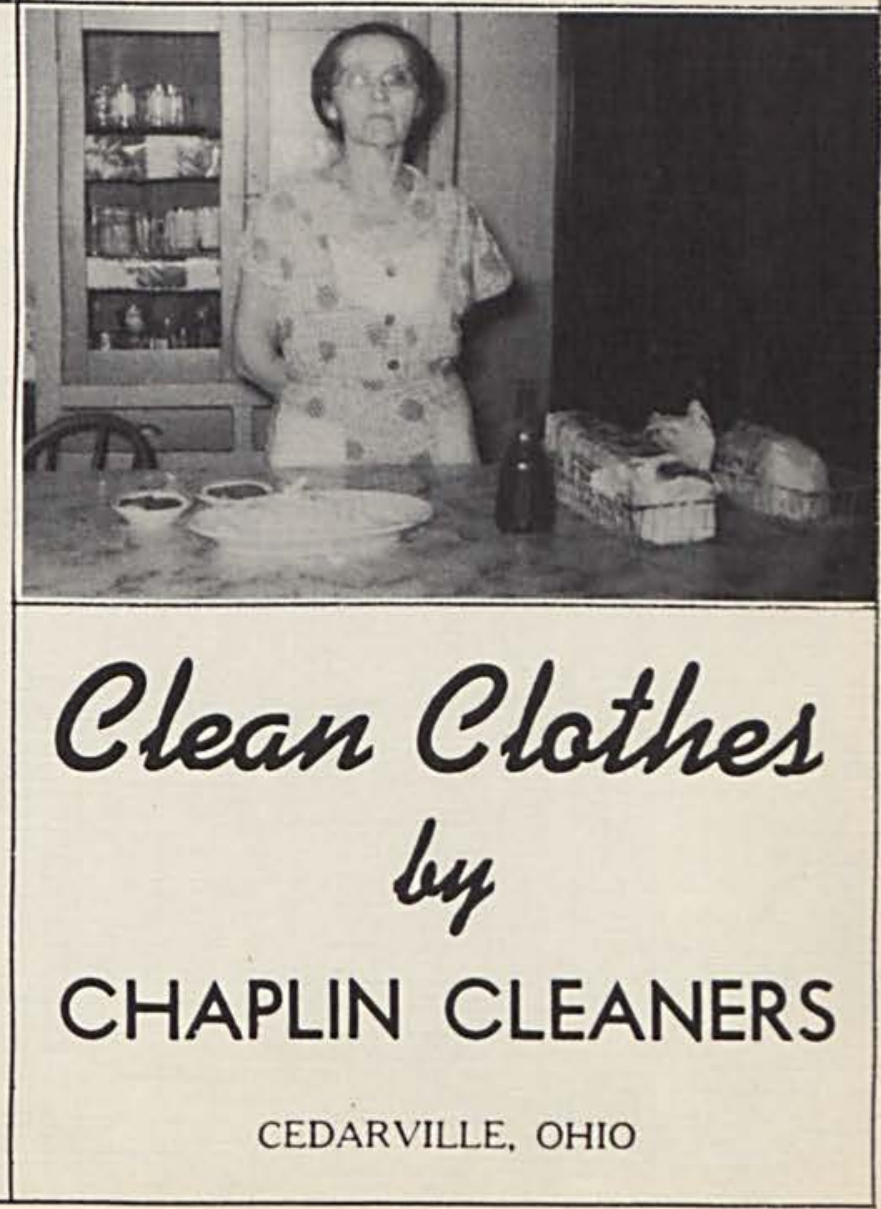




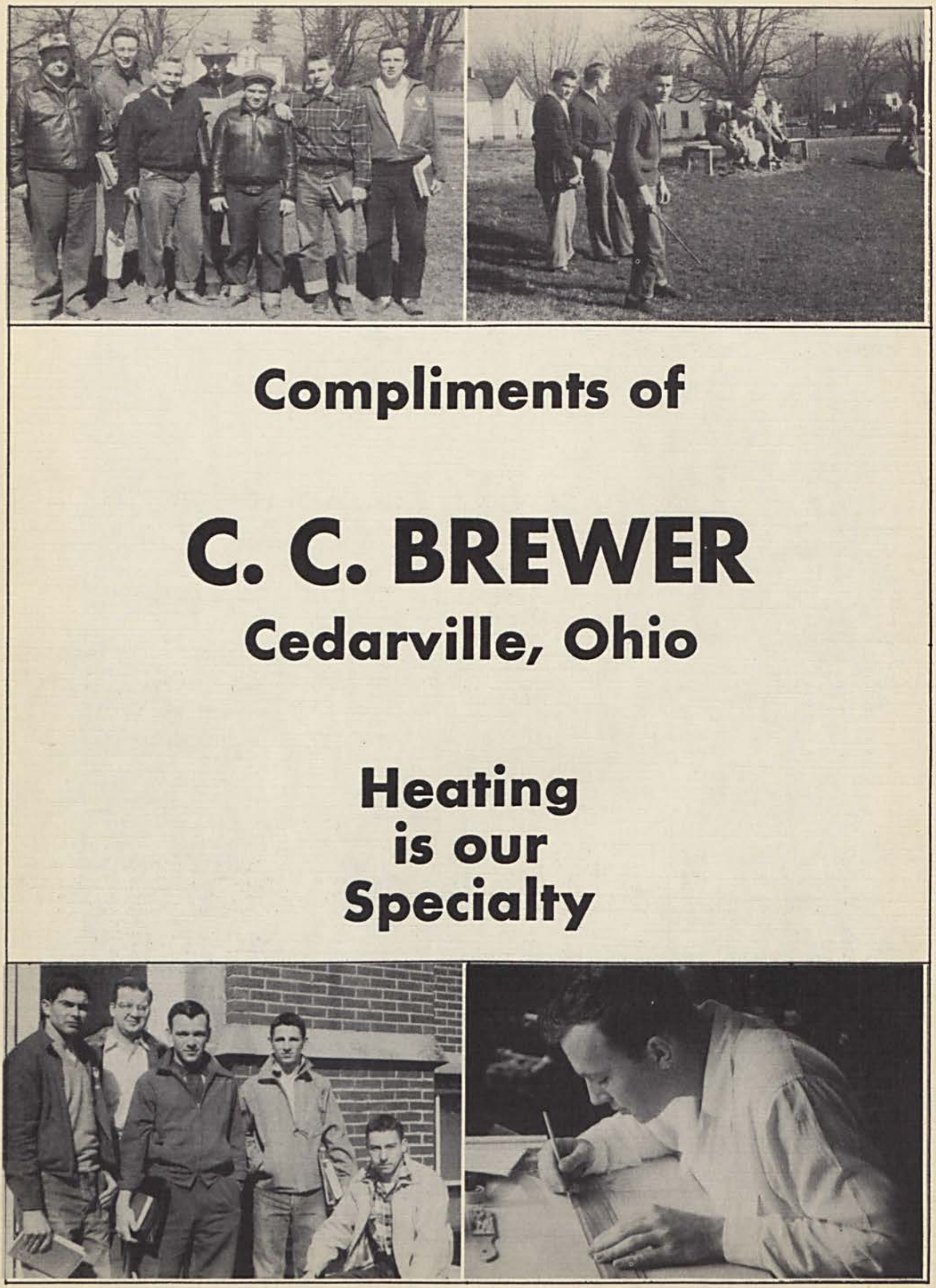




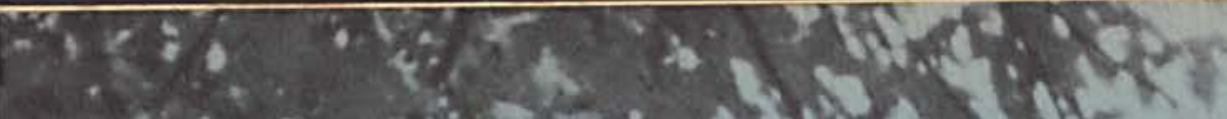

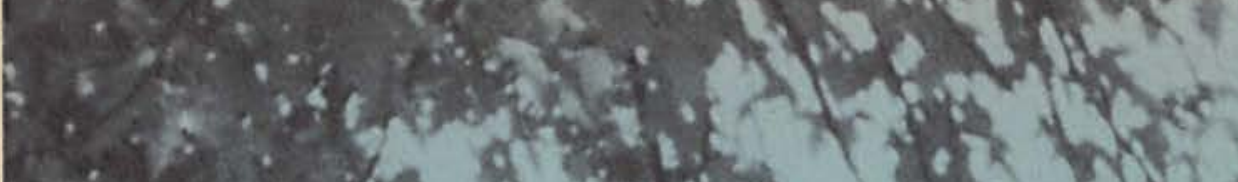

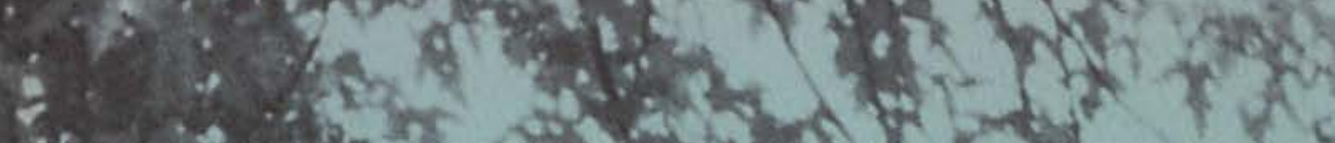

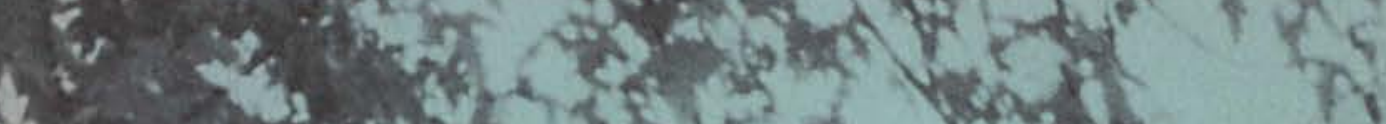

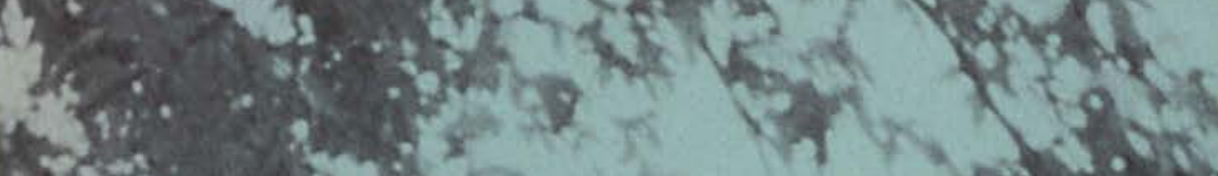
A.

4.42

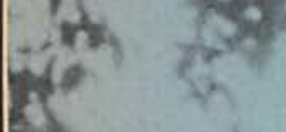

Fes

$27 x^{2}$

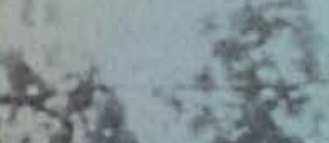

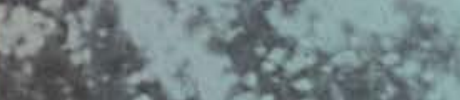

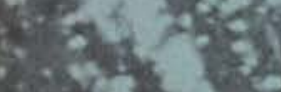

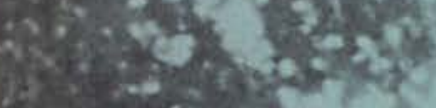

Q teristing

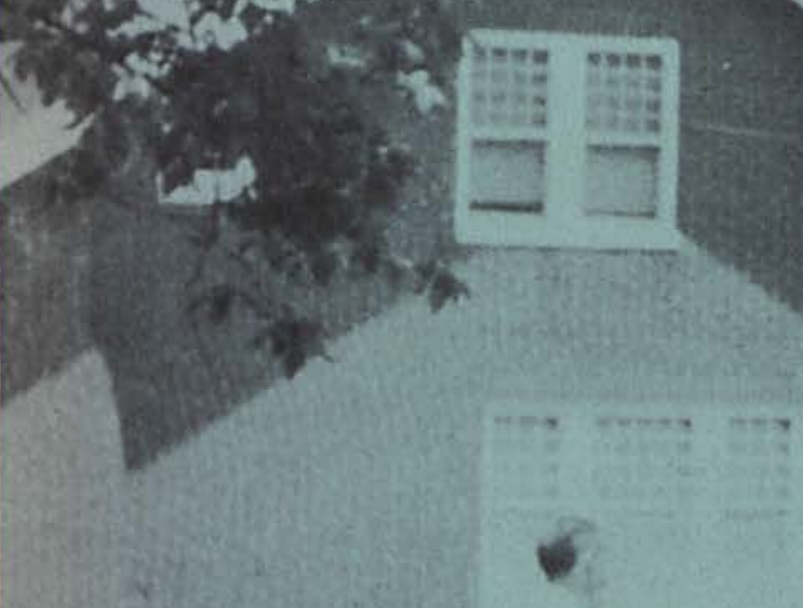

Sis the

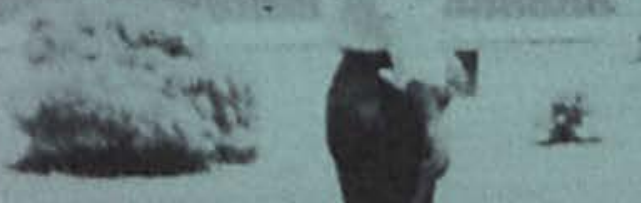

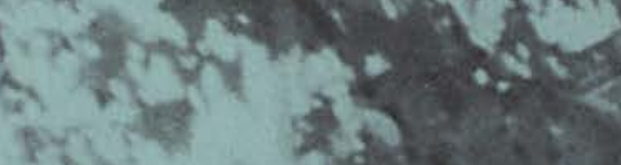
An regtes

ipyom

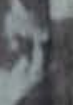

it

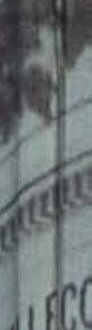




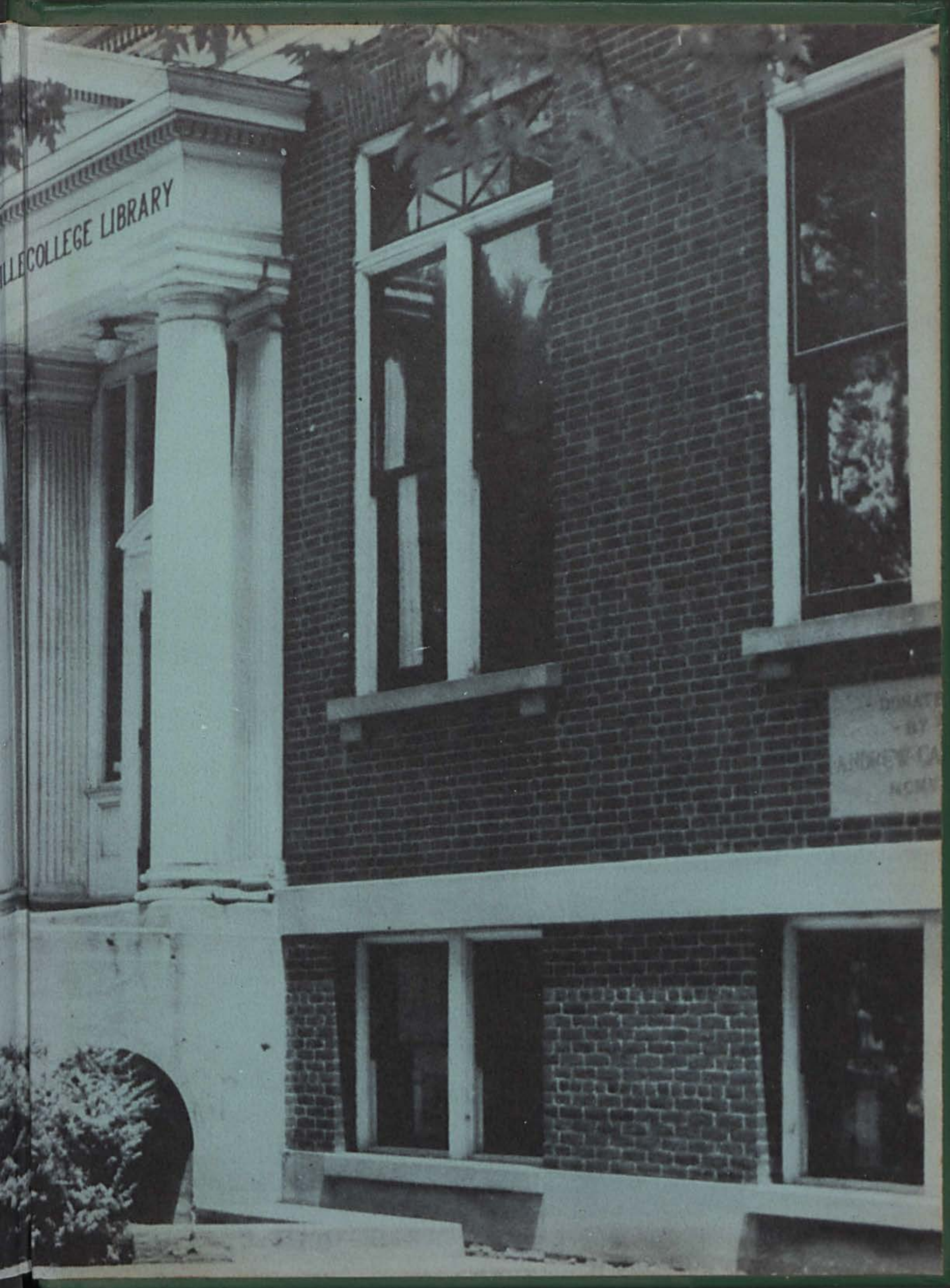




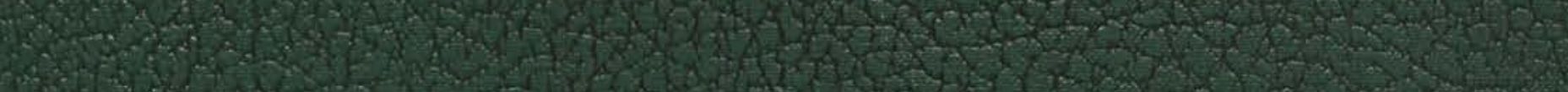

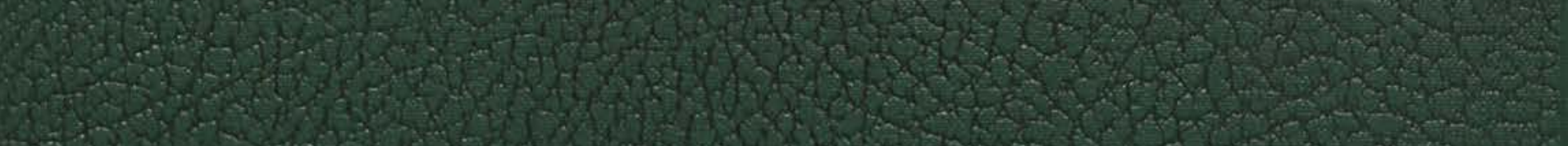

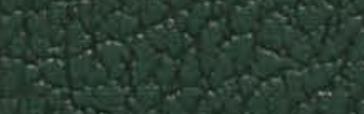

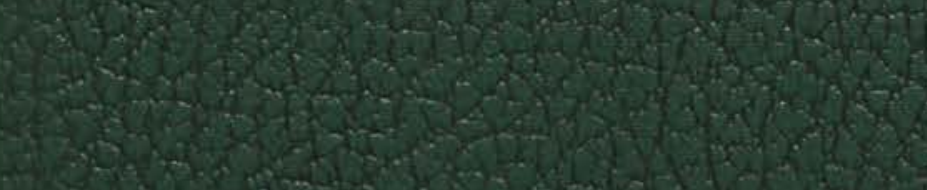

